\title{
Revisiting the Urech Synthesis of Hydantoins: Direct Access to Enan- tiopure 1,5-Substituted Hydantoins using Cyanobenziodoxolone.
}

\author{
Nina Declas, ${ }^{\dagger}$ Franck Le Vaillant, ${ }^{\dagger}$ and Jerome Waser* ${ }^{\dagger \dagger}$ \\ †These authors contributed equality to this work. "Laboratory of Catalysis and Organic Synthesis, Institute of Chemical Sci- \\ ences and Engineering, Ecole Polytechnique Fédérale de Lausanne, EPFL SB ISIC LCSO, BCH 4306, 1015 Lausanne, Swit-
} zerland.

\begin{abstract}
A method for the synthesis of enantiopure 1,5-substituted hydantoins was developed using a hypervalent iodine cyanation reagent (Cyanobenziodoxolone, $\mathrm{CBX}$ ) as a source of electrophilic carbon. Starting from inexpensive commercially available enantiopure protected amino acids, the method allowed the synthesis of various hydantoins without epimerization. Formation of hydantoins from dipeptides was also possible, but partial epimerization was observed in this case. This synthetic strategy is userfriendly as $\mathrm{CBX}$ is a bench-stable easy-to-handle crystalline reagent, and avoid conventional multistep protocols, thus allowing the facile synthesis of a library of chiral hydantoins.
\end{abstract}

Hydantoins (2,4-imidazolidinediones) are important heterocycles in organic chemistry. The most simple hydantoin has been isolated in 1861 by Adolf von Bayer through reduction of allantoin (1) (Figure 1). ${ }^{1}$ Since then, tremendous efforts have been invested to synthesize and study this important family of five-membered heterocycles. ${ }^{2}$ Among them, chiral 5-substituted hydantoins are broadly used as chiral ligands ${ }^{3}$ or auxiliaries, such as hydantoin 2 for enolate functionalization. ${ }^{4}$ Many of them are bioactive compounds, either natural such as $\mathbf{3}$ isolated from the Red Sea sponge Hemimycale arabica,$^{5}$ or synthetic, such as the clinical candidates HR22C16 4 (antimitotic) ${ }^{6}$ and the BMS-564929 (5) (orally active and selective androgen receptor modulator). ${ }^{7}$ Compounds $\mathbf{1 - 5}$ are all derivatives of natural amino acids.
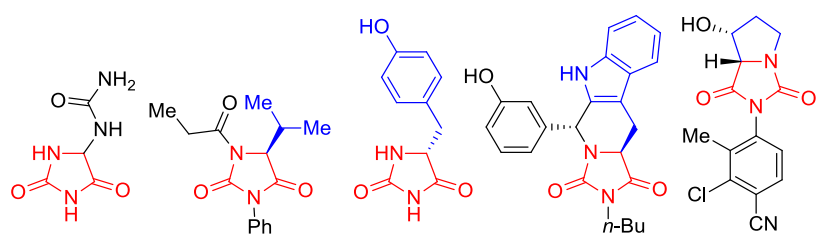

Allantoin (1) Chiral auxiliary (2) Natural product (3) HR22C16 (4) BMS-564929 (5)

Figure 1 Important chiral 5-substituted hydantoins derived from $\alpha$-amino-acids.

The synthesis of hydantoins is well-established. ${ }^{2}$ Classical methods are the Bucherer-Bergs, ${ }^{8}$ the Biltz, ${ }^{9}$ the $\operatorname{Read}^{10}$ and the Urech $^{11}$ syntheses. The two firsts are based on carbonyl or dicarbonyl condensation, affording racemic hydantoins; whereas the Read and Urech's conditions involve a two-step enantioconservative condensation-cyclization of amino-acid derivatives in presence of isocyanates under harsh conditions (Scheme 1). These isocyanates are often not commercially available and their synthesis requires extra steps with often toxic reagents. Since then, efforts towards more environmental and user friendly approaches have been made, especially based on amino acid derivatives. ${ }^{12}$ Using amino amides, Cuny and co-workers were able to obtain enantiopure hydantoins in presence of triphosgene. ${ }^{13}$ Amino amides were also used by Pan and co-work- ers using triflic anhydride, ${ }^{14}$ while Fang and co-workers described a method using amino acid ureas under similar conditions of the Read/Urech cyclization step. ${ }^{15}$ The reaction of $\alpha$ amino methyl ester hydrochlorides with carbamates to produce substituted hydantoins was recently developed by Gill and coworkers. ${ }^{16}$ However, these syntheses still required highly reactive reagents and pre-functionalization of the amino acids. Earlier this year, Gong and co-workers developed an elegant asymmetric synthesis of 5-substituted hydantoins using chiral Lewis base and copper cooperative catalysis. ${ }^{17}$

Scheme 1 Reported syntheses of chiral hydantoins starting from the chiral pool and our previous work on decarboxylative cyanation of amino acids.

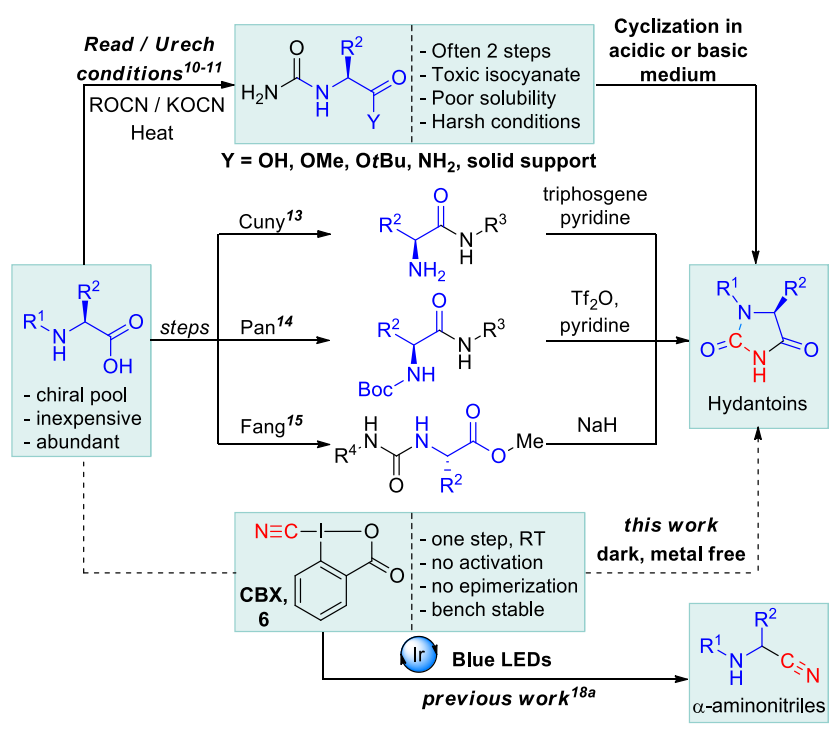

Recently, our group has been interested in transformations of amino acids using hypervalent iodine reagents. ${ }^{18} \mathrm{We}$ reported a room temperature decarboxylative cyanation of carboxylic acids using photoredox catalysis and cyanobenziodoxolone (CBX, 6, Scheme 1). ${ }^{19}$ The synthesis of CBX (6) had been first 
described by Zhdankin, who developed the cyanation of dialkylanilines. ${ }^{20}$ Since then, several electrophilic cyanations using CBX reagents have been described. ${ }^{21,22}$ Herein, we report a new method for the one-step synthesis of 1,5-substituted enantiopure hydantoins, starting from chiral protected amino acids and $\mathrm{CBX}$ (6).

During our previous work on decarboxylative cyanation, screening of different amino acids was performed but the reaction was not always efficient. In fact, the desired transformation did not occur for tryptophan and cysteine. Instead, a hydantoin was formed, as confirmed by X-Ray analysis. ${ }^{23}$ A control experiment on Boc-protected L-alanine $7 \mathbf{a}$ in absence of light and photocatalyst led also to the formation of hydantoin $\mathbf{8 a}$ (Scheme $2,42 \%$ in the dark with 1.25 equiv $\mathrm{CsObz}$ ). This background reaction had not been observed before, as the photoredox mediated process was faster. Based on this unexpected result, different protecting groups on the nitrogen were first examined. Carbamates protecting groups were successful (products 8a-c), and best results were obtained for $\mathrm{Cbz}(\mathbf{8 c})$. In contrast, acetyl- and benzyl protected as well as unprotected amino acids 7 could not be used.

Scheme 2. Screening of N-substituents for the synthesis of hydantoins using CBX (6).

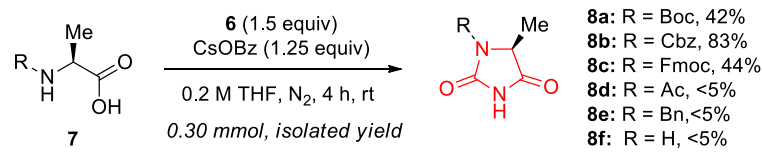

We continued our investigation with optimization of the synthesis of hydantoin $\mathbf{8 b}$ from L-Cbz-Ala (6b) (Table 1). Even though conversion, yield and retention of enantiomeric excess were excellent (95\% conversion, $83 \%$ isolated yield, $95 \%$ ee after $4 \mathrm{~h}$, entry 1 ), we had solubility issues leading to lack of reproducibility. Two chromatography columns were required to separate the desired hydantoin from 2-iodobenzoic acid and benzoic acid. Both $\mathrm{CBX}$ and $\mathrm{CsOBz}$ are poorly soluble in THF, thus making a white slurry. Therefore, different solvents were tested to improve the solubility of the reaction mixture. Dioxane and ethyl acetate (entries 2 and 3) did not allow to enhance the solubility, while a slightly better solubility were observed with DCM and DMF (entries 4 and 5), albeit the yields obtained were lower than in THF. We then decided to screen the base. Neither sodium nor potassium benzoate were superior to cesium benzoate (50 and 60\% yield, entries 6 and 7). Surprisingly cesium carbonate and cesium acetate did not promote the formation of hydantoin (entries 8 and 9). Organic bases such as pyridine and triethylamine gave moderate yields $(60 \%$, entries 10 and 11), while DMAP allowed a clean conversion, better reproducibility and excellent isolated yield (entry 12). When lowering concentration in THF to $0.05 \mathrm{M}$ and $0.1 \mathrm{M}$ (entries 13 and 14), the yield was slightly lower than at $0.2 \mathrm{M}$. The yield dropped to $80 \%$ when increasing the concentration to $0.3 \mathrm{M}$ (entry 15). Screening of CBX derivatives and other cyanation reagents under optimized conditions have also been performed (results not shown, see SI). However, none of the examined reagents allowed to improve neither reactivity nor purification efficiency. Control experiments were performed with other cyanation reagents such as $\mathrm{BrCN}$, ICN and 1-cyano-4-dimethylaminopyridinium tetrafluoroborate (CDAP) instead of CBX (6). Using BrCN and ICN, hydantoin formation could be observed, albeit in lower yield (35\% NMR yield compared to quantitative yield with CBX) while CDAP gave much lower yield $(<20 \%)$.
Table 1. Optimization of the synthesis of hydantoin $8 \mathrm{~b} .^{a}$

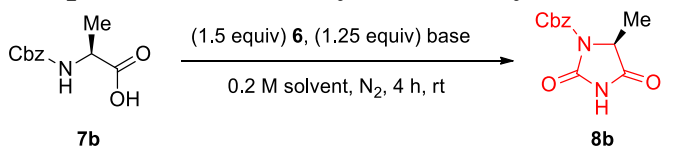

$\begin{array}{ccccc}\text { entry } & \text { base } & \text { solvent } & \begin{array}{c}\text { concentration } \\ (\mathrm{M})\end{array} & \begin{array}{c}\text { NMR yield } \\ (\%)\end{array} \\ 1 & \mathrm{CsOBz} & \text { THF } & 0.2 & >95,83^{b} \\ 2 & \mathrm{CsOBz} & \text { dioxane } & 0.2 & 60 \\ 3 & \mathrm{CsOBz} & \text { EtOAc } & 0.2 & 20 \\ 4 & \mathrm{CsOBz} & \text { DCM } & 0.2 & 45 \\ 5 & \mathrm{CsOBz} & \text { DMF } & 0.2 & 55 \\ 6 & \mathrm{NaOBz} & \text { THF } & 0.2 & 50 \\ 7 & \mathrm{KOBz} & \text { THF } & 0.2 & 60 \\ 8 & \mathrm{Cs} 2 \mathrm{CO}_{3} & \text { THF } & 0.2 & <10 \\ 9 & \mathrm{CsOAc} & \mathrm{THF} & 0.2 & <10 \\ 10 & \text { pyridine } & \text { THF } & 0.2 & 60 \\ 11 & \text { Et } 3 \mathrm{~N} & \text { THF } & 0.2 & 60 \\ 12 & \text { DMAP } & \text { THF } & 0.2 & >95,75^{b} \\ 13 & \text { DMAP } & \text { THF } & 0.05 & 90 \\ 14 & \text { DMAP } & \text { THF } & 0.1 & 90 \\ 15 & \text { DMAP } & \text { THF } & 0.3 & 80\end{array}$

${ }^{a}$ Reaction conditions: $7 \mathbf{b}$ (67 mg, $0.30 \mathrm{mmol}, 1$ equiv), CBX 6 (123 mg, $0.450 \mathrm{mmol}, 1.5$ equiv), base ( $0.375 \mathrm{mmol}, 1.25$ equiv.) in the corresponding solvent $(1.5 \mathrm{~mL})$ for $4 \mathrm{~h}$ at $\mathrm{RT}$ under $\mathrm{N}_{2}$. The NMR yield of $\mathbf{8 b}$ is given. ${ }^{b}$ Isolated yield (\%) after two columns chromatography.

We then studied the scope of amino acids, running the reaction overnight at room temperature to ensure complete conversion for all substrates (Scheme 3). Under these conditions, $\mathrm{Cbz}$ protected L-alanine (7b) is fully converted to hydantoin $\mathbf{8 b}$ with $85 \%$ isolated yield and $96 \%$ ee. Boc and Fmoc protected hydantoins $8 \mathbf{a}$ and $\mathbf{8 c}$ were obtained in better yields. 30\% NMR yield could be observed for acetyl protected hydantoin $\mathbf{8 d}$ and the benzyl protected hydantoin 8e. Less than 5\% NMR yield was observed when using benzamide as protecting group (result not shown). Amino acids bearing apolar side chains (valine, leucine, iso-leucine and phenylalanine) gave the corresponding hydantoins in good to excellent yields $(55-85 \%, \mathbf{8 g - j})$. Tyrosine is suitable for this transformation, but protection of the phenol moiety is required for efficient purification. Protected hydantoin 8k was further crystallized and allowed unambiguously confirmation of the hydantoin core, with full retention of the stereochemistry of the amino acid. ${ }^{22}$ Both L-Cbz-tryptophan and D-Boc-tryptophan based hydantoins $\mathbf{8 1}$ and $\mathbf{8 m}$ were obtained in good yields. L-Methionin, L-S(Bn)-cysteine, L$\mathrm{N}(\mathrm{Boc})$-lysine, L-O $(t \mathrm{Bu})$-glutamatic acid and $\mathrm{L}-\mathrm{O}(t \mathrm{Bu})$-asparagic acid and $\mathrm{L}-\mathrm{O}(\mathrm{Bn})$-serine were successfully converted to the corresponding hydantoins $\mathbf{8 n - s}$ in good to excellent yields (54-82\%). It is also possible to use unnatural amino acids. For example hydantoin 8t with a cyclopropyl side chain was obtained in $65 \%$ yield. Surprisingly, although the nitrogen of Lproline is electron-rich, $62 \%$ of bicyclic hydantoin $8 \mathbf{u}$ was isolated. Hydantoin $8 \mathbf{v}$ was obtained from glycine in $88 \%$ yield. Hydantoin $\mathbf{8 v}$ can be condensed with benzaldehyde derivatives to afford bioactive methylenehydantoins. ${ }^{5,24}$ Sterically hindered 
hydantoin 8w was obtained in $56 \%$ yield. Side chain unprotected asparagine, glutamine, threonine, histidine and cysteine were unsuccessful.

Scheme 3 Scope of amino acids. ${ }^{a}$

$$
\text { (1.5 equiv), DMAP(1.25 equiv) }
$$

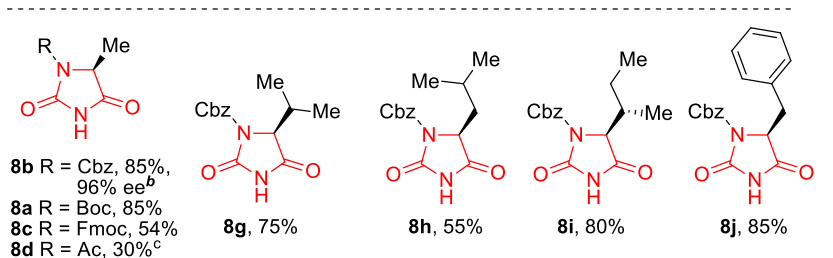

$$
8 d \mathrm{~d}=\mathrm{Ac}, 30 \%^{\mathrm{C}}
$$

$8 \mathrm{e} R=\mathrm{Bn}, 30 \%$
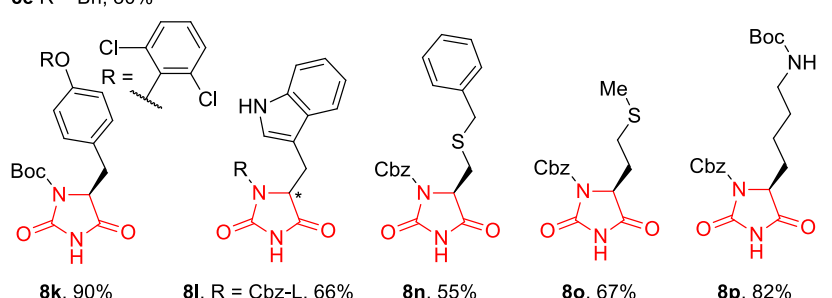

$$
\begin{array}{ll}
\mathbf{8 k}, 90 \% & \mathbf{8 1}, \mathrm{R}=\mathrm{Cbz}-\mathrm{L}, 66 \% \\
\mathbf{8 m}, \mathrm{R}=\mathrm{Boc}-\mathrm{D}, \mathbf{8 6} \%
\end{array}
$$$$
8 \text { n, } 55 \%
$$

$80,67 \%$

$8 p, 82 \%$

$$
\text { 8q, } 54 \% \quad \text { 8r, }
$$$$
\mathrm{R}^{2}=\mathrm{Me}, 56 \%
$$

${ }^{a}$ Reaction conditions: 7 (0.15 mmol, 1.0 equiv.), CBX (6) $(61 \mathrm{mg}$, $0.23 \mathrm{mmol}, 1.5$ equiv.), DMAP ( $23 \mathrm{mg}, 0.19 \mathrm{mmol}, 1.25$ equiv.) in THF $(0.75 \mathrm{~mL})$ for $16 \mathrm{~h}$ at RT under $\mathrm{N}_{2}$. Isolated yield of 8 after purification by preparative TLC (Heptane/Et $2 \mathrm{O})$ is given. ${ }^{b}$ ee was measured by chiral HPLC. ${ }^{\mathrm{c}} \mathrm{NMR}$ yield.

To highlight the efficiency of this transformation, a gram scale synthesis was undertaken and $1.2 \mathrm{~g}$ of optically pure hydantoin $\mathbf{8 b}$ was obtained (Scheme 4, equation 1), along with the recovery of $1.75 \mathrm{~g}$ of the precipitated salt $\mathbf{9}$. Cbz deprotection of $\mathbf{8 b}$ to give 10 was quantitative using $5 \mathrm{~mol} \%$ of $\mathrm{Pd}(\mathrm{OH})_{2} / \mathrm{C}$ in methanol (equation 2).

Scheme 4 Gram-scale synthesis and Cbz deprotection of hydantoin $8 b .^{a}$

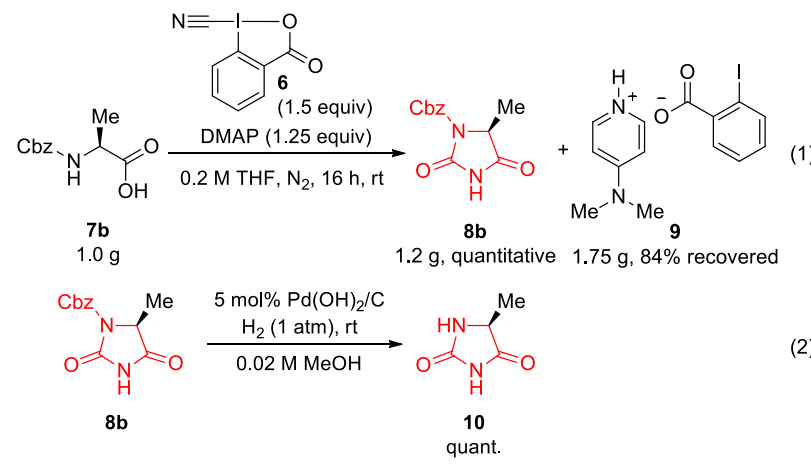

${ }^{a}$ Reaction conditions: (1) 7b (1.0 g, 4.5 mmol, 1.0 equiv.), CBX (6) (1.84 g, $6.72 \mathrm{mmol}, 1.5$ equiv.), DMAP (0.68 g, $5.6 \mathrm{mmol}, 1.25$ equiv.) for $16 \mathrm{~h}$ at RT. Isolated yield of $\mathbf{8 b}$ after filtration and column chromatography. (2) $\mathbf{8 b}$ (30 $\mathrm{mg}, 0.12 \mathrm{mmol}, 1.00$ equiv.),
$\mathrm{Pd}(\mathrm{OH})_{2} / \mathrm{C}(6.1 \mu \mathrm{mol}, 5 \mathrm{~mol} \%)$ in $\mathrm{MeOH}(6.0 \mathrm{~mL})$ for $4 \mathrm{~h}$ at $\mathrm{RT}$ under $\mathrm{H}_{2}$. Isolated yield of $\mathbf{1 0}$ after filtration over HPLC filter.

We then wondered if the reaction could be applied on peptides to access more complex hydantoins. Indeed, the formation of the hydantoin was feasible on Cbz protected Ala-Ala-OH and Gly-Phe-OH dipeptides 11a and 11b (Scheme 5), even though the reaction was slower. After $36 \mathrm{~h}$ at room temperature, hydantoins 12a and 12b were obtained in $80 \%$ and $64 \%$ isolated yield respectively. In contrast to amino acids, some epimerization occurred, leading to a decrease of diastereomeric/enantiomeric excess (12a, $72 \%$ de; $\mathbf{1 2 b}, 44 \%$ ee). This may be due to the prolonged reaction time under basic conditions.

Scheme 5 C-terminal hydantoin formation on dipeptides 11. ${ }^{a}$
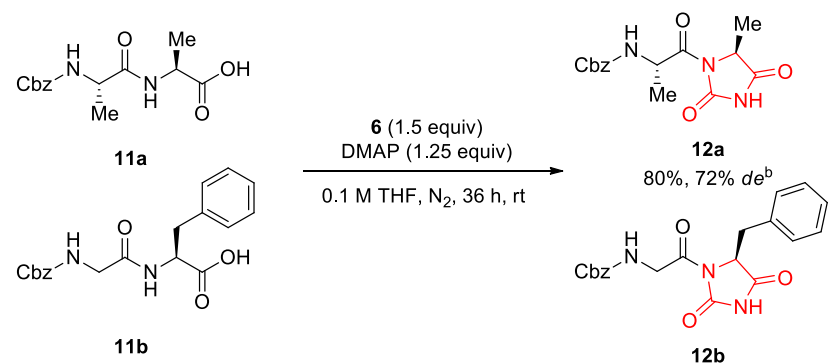

$64 \%, 44 \% e e^{b}$

${ }^{a}$ Reaction conditions: 11 ( 0.15 mmol, 1.0 equiv.), CBX (6) (61 mg, $0.23 \mathrm{mmol}, 1.5$ equiv.), DMAP (23 mg, $0.19 \mathrm{mmol}, 1.25$ equiv.) in THF $(0.75 \mathrm{~mL})$ for $16 \mathrm{~h}$ at RT under $\mathrm{N}_{2}$. Isolated yield of 12 after purification by preparative TLC (Heptane/Et $2 \mathrm{O}$ ) is given. ${ }^{b}$ Measured by chiral HPLC.

A speculative mechanism is outlined in Scheme 6. We envisioned that deprotonation of amino acid 7 by DMAP will lead to carboxylate 7'. Cyanation with CBX 6 gives then mixed anhydride intermediate $\mathbf{I}$ and salt $\mathbf{9}$, which was indeed isolated at the end of the reaction. Cyclization of intermediate $\mathbf{I}$, affording the corresponding 2-iminooxazolidin-5-one II appears highly probable.

Scheme 6 Speculative mechanism for hydantoin formation.

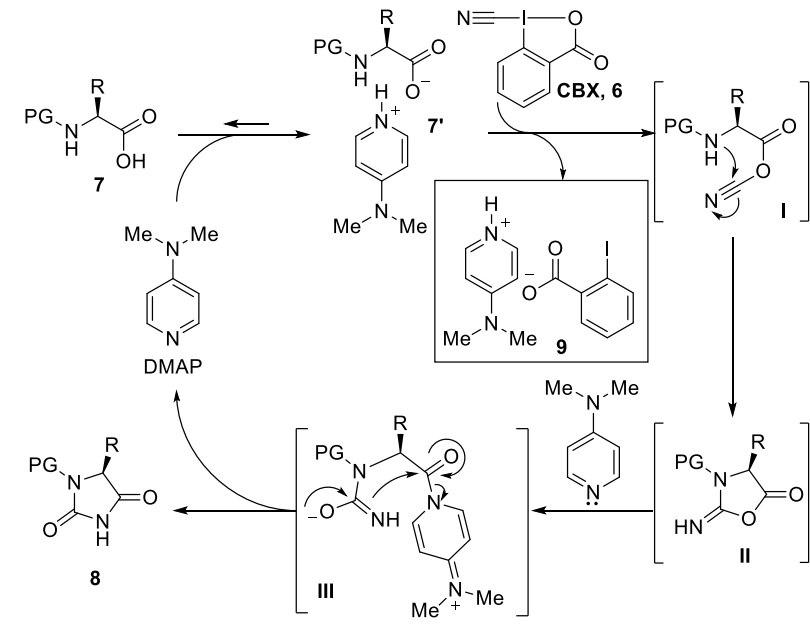

Subsequent rearrangement of II to more stable hydantoin $\mathbf{8}$ may be accelerated by DMAP as a nucleophilic catalyst, via intermediate III. A possible alternative inspired from Urech synthesis is a nucleophilic attack of DMAP on the activated car- 
bonyl of I releasing in situ a cyanate anion, which after condensation on the amine would also give intermediate III. Concerning transfer of the cyanide group, several pathways can be proposed (See SI details). Based on our previous work on thiocyanation with $\mathrm{CBX},{ }^{19 \mathrm{a}}$ a concerted mechanism via a three-atom transition state could be considered, but a stepwise process cannot be excluded. Mechanisms involving a single electron transfer and subsequent formation of radical intermediates also constitute an alternative when considering the strong oxidizing properties of hypervalent iodine reagents. ${ }^{19,25}$

In conclusion, we have developed an efficient and practical method for the synthesis of 1,5-substituted enantiopure hydantoins. Starting from chiral amino acids, the reaction proceeds at room temperature, using cyanobenziodoxolone (CBX, 6) and DMAP. A broad range of hydantoins could be synthesized without epimerization starting from protected amino acids, whereas partial epimerization was observed in the case of dipeptides. The method is expected to be highly useful in synthetic and medicinal chemistry.

\section{ASSOCIATED CONTENT}

\section{Supporting Information}

Experimental procedures and analytical data for all new compounds. This material is available free of charge via the Internet at http://pubs.acs.org.

\section{AUTHOR INFORMATION}

\section{Corresponding Author}

*jerome.waser@epfl.ch

\section{ACKNOWLEDGMENT}

We thank the European Research Council (ERC Starting Grant 334840) and the Institute of Chemistry and Chemical Engineering at EPFL (Master grant for N. D.) for financial support. Dr Rosario Scopelliti, Dr Euro Solari and Dr Farzaneh Fadaei Tirani (ISIC, EPFL) are acknowledged for the X-ray study. Bastian Muriel from LCSO is acknowledged for the purification of hydantoin $\mathbf{8 t}$. Paola Caramenti and Phillip Greenwood from LCSO are acknowledged for their help with the HPLC analysis.

\section{REFERENCES}

(1) Biltz, H.; Slotta, K. Über die Herstellung von Hydantoinen. $J$. Prakt. Chem. 1926, 113, 233.

(2) (a) Ware, E. The Chemistry of the Hydantoins. Chem. Rev. 1950, 46, 403. (b) Lopez, C. A.; Trigo, G. G. The Chemistry of Hydantoins. in Adv. Heterocycl. Chem., 38 (Ed.: R. K. Alan), Academic Press, 1985, 177-228. (c) Meusel, M.; Gütschow, M. Recent Developments in Hydantoin Chemistry. A Review. Org. Prep. Proced. Int. 2004, 36, 391. (d) Konnert, L.; Reneaud, B.; de Figueiredo, R. M.; Campagne, J.-M.; Lamaty, F.; Martinez, J.; Colacino, E. Mechanochemical Preparation of Hydantoins from Amino Esters: Application to the Synthesis of the Antiepileptic Drug Phenytoin. J. Org. Chem. 2014, 79, 10132. (e) Konnert, L.; Lamaty, F.; Martinez, J.; Colacino, E. Recent Advances in the Synthesis of Hydantoins: The State of the Art of a Valuable Scaffold. Chem. Rev. 2017, 117, 13757.

(3) Metallinos, C.; John, J.; Zaifman, J.; Emberson, K. A. Diastereoselective Synthesis of N-Substituted Planar Chiral Ferrocenes Using a Proline Hydantoin-Derived Auxiliary. Adv. Synth. Catal. 2012, 354, 602 .

(4) (a) Yamaguchi, J. I.; Harada, M.; Narushima, T.; Saitoh, A.; Nozaki, K.; Suyama, T. Diastereoselective Conjugate Addition of 1$(\alpha, \beta$-Unsaturated Acyl)Hydantoin with Nucleophiles. Tetrahedron Lett. 2005, 46, 6411. (b) Zhang, J.-S.; Lu, C.-F.; Chen, Z.-X.; Li, Y.;
Yang, G.-C. Boron Enolates of a Hydantoin Chiral Auxiliary Derived From L-Phenylalanine: A Versatile Tool For Asymmetric Aldol Reactions. Tetrahedron: Asymmetry 2012, 23, 72. (c) Lu, G.-J.; Nie, J.-Q.; Chen, Z.-X.; Yang, G.-C.; Lu, C.-F. Synthesis and Evaluation of a New Non-Cross-Linked Polystyrene Supported Hydantoin Chiral Auxiliary for Asymmetric Aldol Reactions. Tetrahedron: Asymmetry 2013, 24 , 1331.

(5) Mudit, M.; Khanfar, M.; Muralidharan, A.; Thomas, S.; Shah, G. V.; Van Soest, R. W. M.; El Sayed, K. A. Discovery, Design, and Synthesis of Anti-Metastatic Lead Phenylmethylene Hydantoins Inspired by Marine Natural Products. Bioorg. Med. Chem. 2009, 17, 1731.

(6) Hotha, S.; Yarrow, J. C.; Yang, J. G.; Garrett, S.; Renduchintala, K. V.; Mayer, T. U.; Kapoor, T. M. HR22C16: A Potent Small-Molecule Probe for the Dynamics of Cell Division. Angew. Chem., Int. Ed. 2003, 42, 2379.

(7) Ostowski, J.; Kuhns, J. E.; Lupisella, J. A.; Manfredi, M. C.; Beehler, B. C.; Krystek, S. R.; Jr, Bi, Y.; Sun, C.; Seethala, R.; Golla, R.; Sleph, P. G.; Fura, A.; An, Y.; Kish, K. F.; Sack, J. S.; Mookhtiar, K. A.; Grover, G. J.; Hamann, L. G. Pharmacological and X-Ray Structural Characterization of a Novel Selective Androgen Receptor Modulator: Potent Hyperanabolic Stimulation of Skeletal Muscle with Hypostimulation of Prostate in Rats. Endocrinology 2007, 148, 4.

(8) Bucherer, H. T.; Lieb, V. A. Über die Bildung Substituierter Hydantoine aus Aldehyden und Ketonen. Synthese von Hydantoinen. J. Prakt. Chem. 1934, 141, 5.

(9) Biltz, H. Über die Konstitution der Einwirkungsprodukte von substituierten Harnstoffen auf Benzil und über einige neue Methoden zur Darstellung der 5,5-Diphenylhydantoine. Ber. Dtsch. Chem. Ges. 1908, 41,1379

(10) Read, W. T. Researches on Hydantoins. Synthesis of the Soporific 4,4-Phenylethyl-Hydantoin (Nirvanol). J. Am. Chem. Soc. 1922, $44,1746$.

(11) Urech, F. Ueber Lacturaminsäure und Lactylharnstoff. Justus Liebigs Ann. Chem. 1873, 165, 99.

(12) It is unclear in the following publications if the hydantoins obtained are optically pure when using chiral aminoesters and amino amide respectively. (a) Bogolubsky, A. V.; Moroz, Y. S.; Savych, O.; Pipko, S.; Konovets, A.; Platonov, M.; Vasylchenko, O. V.; Hurmach, V. V.; Grygorenko, O. O. An Old Story in the Parallel Synthesis World: An Approach to Hydantoin Libraries. ACS. Comb. Sci. 2018, 20, 35. (b) Dumbris, S. M.; Diaz, D. J.; McElwee-White, L. Preparation of Hydantoins by Catalytic Oxidative Carbonylation of $\alpha$-Amino Amides. J. Org. Chem. 2009, 74, 8862.

(13) Zhang, D.; Xing, X.; Cuny, G. D. Synthesis of Hydantoins from Enantiomerically Pure $\alpha$-Amino Amides without Epimerization. $J$. Org. Chem. 2006, 71, 1750 .

(14) Liu, H.; Yang, Z.; Pan, Z. Synthesis of Highly Substituted Imidazolidine-2,4-dione (Hydantoin) through $\mathrm{Tf}_{2} \mathrm{O}$-Mediated Dual Activation of Boc-Protected Dipeptidyl Compounds. Org. Lett. 2014, 16, 5902.

(15) Chen, Y.; Su, L.; Yang, X.; Pan, W.; Fang, H. Enantioselective Synthesis of 3,5-Disubstituted Thiohydantoins and Hydantoins. Tetrahedron 2015, 71, 9234.

(16) Tanwar, D. K.; Ratan, A.; Gill, M. S.; Facile One-Pot Synthesis of Substituted Hydantoins from Carbamates, Synlett. 2017, 28, 2285.

(17) Song, J.; Zhang, Z.-J.; Chen, S.-S.; Fan, T.; Gong, L.-Z. Lewis Base/Copper Cooperatively Catalyzed Asymmetric $\alpha$-Amination of Esters with Diaziridinone. J. Am. Chem. Soc. 2018, 140, 3177.

(18) (a) Le Vaillant, F.; Courant, T.; Waser, J. Room-Temperature Decarboxylative Alkynylation of Carboxylic Acids Using Photoredox Catalysis and EBX Reagents. Angew. Chem., Int. Ed. 2015, 54, 11200. (b) Tolnai, G. L.; Brand, J. P.; Waser, J. Gold-Catalyzed Direct Alkynylation of Tryptophan in Peptides Using TIPS-EBX. Beilstein J. Org. Chem. 2016, 12, 745. (c) Frei, R.; Wodrich, M. D.; Hari, D. P.; Borin, P. A.; Chauvier C.; Waser, J. Fast and Highly Chemoselective Alkynylation of Thiols with Hypervalent Iodine Reagents Enabled through a Low Energy Barrier Concerted Mechanism. J. Am. Chem. Soc. 2014, 136, 16563.

(19) (a) Le Vaillant, F.; Wodrich, M. D.; Waser, J. Room Temperature Decarboxylative Cyanation of Carboxylic Acids Using Photoredox 
Catalysis and Cyanobenziodoxolones: A Divergent Mechanism Compared to Alkynylation. Chem. Sci. 2017, 8, 1790. (b) Le Vaillant, F.; Waser, J. Decarboxylative Alkynylation and Cyanation of Carboxylic Acids using Photoredox Catalysis and Hypervalent Iodine Reagents. Chimia 2017, 71, 226.

(20) Zhdankin, V. V.; Kuehl, C. J.; Krasutsky, A. P.; Bolz, J. T.; Mismash, B.; Woodward, J. K.; Simonsen, A. J. 1-Cyano-3-(1H)-1,2benziodoxols: Stable Cyanoiodinanes and Efficient Reagents for Direct N-Alkyl Cyanation of N,N-Dialkylarylamines. Tetrahedron Lett. 1995 36, 7975 .

(21) (a) Wang, Y. F.; Qiu, J.; Kong, D.; Gao, Y.; Lu, F.; Karmaker, P. G.; Chen, F. X. The Direct Electrophilic Cyanation of $\beta$-Keto Esters and Amides With Cyano Benziodoxole. Org. Biomol. Chem. 2015, 13 , 365. (b) Chowdhury, R.; Schörgenhumer, J.; Novacek, J.; Waser, M., Towards an Asymmetric Organocatalytic $\alpha$-Cyanation of $\beta$-Ketoesters. Tetrahedron Lett. 2015, 56, 1911. (c) Ma, B.; Lin, X.; Lin, L.; Feng, X.; Liu, X. Chiral N,N'-Dioxide Organocatalyzed Asymmetric Electrophilic $\alpha$-Cyanation of $\beta$-Keto Esters and $\beta$-Keto Amides. J. Org. Chem. 2017, 82, 701.

(22) (a) Li, Y.; Hari, D. P.; Vita, M. V.; Waser, J. Cyclic Hypervalent Iodine Reagents for Atom-Transfer Reactions: Beyond Trifluoromethylation. Angew. Chem. Int. Ed. 2016, 55, 4436. (b) Frei, R.; Courant, T.; Wodrich, M. D.; Waser, J. General and Practical Formation of Thiocyanates from Thiols. Chem. Eur. J. 2015, 21, 2662. (c) Vita, M. V.; Caramenti, P.; Waser, J. Enantioselective Synthesis of Homoallylic Azides and Nitriles via Palladium-Catalyzed Decarboxylative Allylation. Org. Lett. 2015, 17, 5832.

(23) Crystal structure of $\mathbf{8 i}$ is available at CCDC under number 1869712.

(24) (a) Sallam, A. A.; Mohyeldin, M. M.; Foudah, A. I.; Akl, M. R.; Nazzal, S.; Meyer, S. A.; Liu, Y. Y.; El Sayed, K. A. Marine Natural Products-Inspired Phenylmethylene Hydantoins with Potent In Vitro and In Vivo Antitumor Activities via Suppression of BRK and FAK Signaling. Org. Biomol. Chem. 2014, 12, 5295. (b) Azizmohammadi, M.; Khoobi, M.; Ramazani, A.; Emami, S.; Zarrin, A.; Firuzi, O.; Miri, R.; Shafiee, A. 2H-Chromene Derivatives Bearing Thiazolidine2,4-Dione, Rhodanine or Hydantoin Moieties as Potential Anticancer Agents. Eur. J. Med. Chem. 2013, 59, 15.

(25) Only trace amount of nitrile resulting from decarboxylative cyanation of peptide 11a was isolated and characterized by HRMS after $48 \mathrm{~h}$ at $50{ }^{\circ} \mathrm{C}$. A SET pathway for hydantoin synthesis would be expected to lead to a higher extent of such side product. 


$$
\text { dark, metal free }
$$


Supporting Information for

\title{
Revisiting the Urech Synthesis of Hydantoins: Direct Access to Enantiopure 1,5-Substituted Hydantoins using Cyanobenziodoxolone.
}

\author{
Nina Declas, ${ }^{\mathrm{XX}}$ Franck Le Vaillant, ${ }^{\mathrm{XX}}$ and Jérôme Waser* \\ ${ }^{\mathrm{XX}}$ These authors contributed equality to this work. Laboratory of Catalysis and Organic \\ Synthesis, Ecole Polytechnique Fédérale de Lausanne, EPFL SB ISIC LCSO, BCH 4306, \\ 1015 Lausanne, Switzerland \\ jerome.waser@epfl.ch
}

(81 pages) 


\section{Table of Contents}

1. General Methods $\quad$ S3

2. Preparation of Reagents $\quad$ S4

3. Hydantoin synthesis $\quad$ S15

$\begin{array}{ll}\text { 4. Transition State Hypothesis } & \text { S29 }\end{array}$

5. Spectra of New Compounds $\quad$ S30 


\section{General Methods}

HPLC grade or freshly distilled solvents purchased from Sigma-Aldrich were used. All reagents and solvents were purchased from commercial sources ABCR, Acros, Sigma Aldrich, Fluka, VWR, Aplichem or Merck and used as such unless stated otherwise. Chromatographic purification was performed as flash chromatography using Macherey-Nagel silica 40-63, $60 \AA$. TLC was performed on Merck silica gel 60 F254 TLC glass plates and visualized with UV light, permanganate stain or phosphomolybdic acid stain. Melting points were measured on a calibrated Büchi B-540 melting point apparatus using open glass capillaries. ${ }^{1} \mathrm{H}-\mathrm{NMR}$ spectra were recorded on a Bruker DPX-400 $400 \mathrm{MHz}$ spectrometer in $\mathrm{CDCl}_{3}, \mathrm{CD}_{2} \mathrm{Cl}_{2}$, DMSO-d6, $\mathrm{CD}_{3} \mathrm{OD}$; all signals are reported in ppm with the internal chloroform signal at $7.26 \mathrm{ppm}$, the internal $\mathrm{CD}_{2} \mathrm{Cl}_{2}$ signal at $5.32 \mathrm{ppm}$, the internal DMSO signal at $2.50 \mathrm{ppm}$ or the internal methanol signal at $3.30 \mathrm{ppm}$ as standard. The data is being reported as ( $\mathrm{s}=\operatorname{singlet} \mathrm{d}=\mathrm{doublet}$ $\mathrm{t}=$ triplet $\mathrm{q}=$ quadruplet quint $=$ quintet $\mathrm{m}=$ multiplet or unresolved $\mathrm{bs}=$ broad signal, coupling constant(s) in $\mathrm{Hz}$, integration, interpretation). ${ }^{19} \mathrm{~F}-\mathrm{NMR}$ spectra were recorded on a Bruker DPX-400 $376 \mathrm{MHz}$ spectrometer in $\mathrm{CDCl}_{3} .{ }^{13} \mathrm{C}-\mathrm{NMR}$ spectra were recorded with ${ }^{1} \mathrm{H}$ decoupling on a Bruker DPX-400 $101 \mathrm{MHz}$ spectrometer in $\mathrm{CDCl}_{3}, \mathrm{CD}_{2} \mathrm{Cl}_{2}$, DMSO-d6, $\mathrm{CD}_{3} \mathrm{OD}$; all signals are reported in ppm with the internal chloroform signal at $77.2 \mathrm{ppm}$, the internal $\mathrm{CD}_{2} \mathrm{Cl}_{2}$ signal at $54.0 \mathrm{ppm}$, the internal DMSO signal at $39.5 \mathrm{ppm}$ or the internal methanol signal at $49.0 \mathrm{ppm}$ as standard. Infrared spectra were recorded on a JASCO FT-IR B4100 or a Brucer Alpha-P spectrophotometer with an ATR device and a ZnSe prisma and are reported as cm-1 ( $\mathrm{w}=$ weak, $\mathrm{m}=$ medium, $\mathrm{s}=$ strong, $\mathrm{br}=$ broad $)$. High resolution mass spectrometric measurements were performed by the mass spectrometry service of ISIC at the EPFL on a MICROMASS (ESI) Q-TOF Ultima API. HPLC measurements were done on a Agilent 1260 Infinity autosampler using a CHIRALPAK ID column from DAICEL Chemical. Samples were prepared in a 80/20 hexane/isopropanol mixture, before being submitted in chiral HPLC. Optical rotations were measured on a polarimeter using a $10 \mathrm{~cm}$ cell with a $\mathrm{Na} 589 \mathrm{~nm}$ filter. The specific solvents and concentrations (in $\mathrm{g} / 100 \mathrm{~mL}$ ) are indicated. All amino acids and peptides used in this work were commercially available and used as received. 


\section{Preparation of Reagents}

The synthesis of reagents $\mathbf{6}$ and $\mathbf{6 b - f}$ had already been described before by our group. The procedures are taken from the indicated publications to facilitate reproduction of the results by having all data in the same file.

\section{1-Hydroxy-1,2-benziodoxol-3-(1H)-one (14)}<smiles>O=C(O)c1ccccc1I</smiles>

13

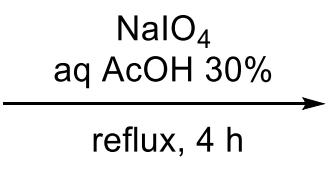

reflux, $4 \mathrm{~h}$<smiles>O=C1OI(O)c2ccccc21</smiles>

14

Following a reported procedure, ${ }^{[1]} \mathrm{NaIO}_{4}(7.24 \mathrm{~g}, 33.8 \mathrm{mmol}, 1.05$ equiv) and 2-iodobenzoic acid (13) (8.00 g, $32.2 \mathrm{mmol}, 1.00$ equiv) were suspended in 30\% (v:v) aq. AcOH (48 mL). The mixture was vigorously stirred and refluxed for $4 \mathrm{~h}$. The reaction mixture was then diluted with cold water $(180 \mathrm{~mL})$ and allowed to cool to rt, protecting it from light. After $1 \mathrm{~h}$, the crude product was collected by filtration, washed on the filter with ice water $(3 \times 20 \mathrm{~mL})$ and acetone ( 3 x $20 \mathrm{~mL})$, and air-dried in the dark to give the pure product $14(8.3 \mathrm{~g}, 31 \mathrm{mmol}, 98 \%)$ as a colorless solid. ${ }^{1} \mathrm{H}$ NMR (400 MHz, $\left.\left(\mathrm{CD}_{3}\right)_{2} \mathrm{SO}\right) \delta 8.02(\mathrm{dd}, J=7.7,1.4 \mathrm{~Hz}, 1 \mathrm{H}, \mathrm{ArH}), 7.97$ (m, $1 \mathrm{H}, \mathrm{Ar} H), 7.85(\mathrm{dd}, J=8.2,0.7 \mathrm{~Hz}, 1 \mathrm{H}, \mathrm{Ar} H), 7.71(\mathrm{td}, J=7.6,1.2 \mathrm{~Hz}, 1 \mathrm{H}, \mathrm{Ar} H) ;{ }^{13} \mathrm{C} \mathrm{NMR}$ $\left(100 \mathrm{MHz},\left(\mathrm{CD}_{3}\right)_{2} \mathrm{SO}\right) \delta 167.7,134.5,131.5,131.1,130.4,126.3,120.4$; IR $v 3083(\mathrm{w}), 3060$ (w), 2867 (w), 2402 (w), 1601 (m), 1585 (m), 1564 (m), 1440 (m), 1338 (s), 1302 (m), 1148 (m), 1018 (w), $834(\mathrm{~m}), 798$ (w), 740 (s), 694 (s), 674 (m), 649 (m). The reported values correspond to the ones in literature. ${ }^{[1]}$

\section{1-Acetoxy-1,2-benziodoxol-3-(1H)-one (15)}<smiles>O=C1OI(O)c2ccccc21</smiles>

14

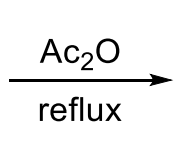

(1)<smiles>CC(=O)OI1C(=O)OCc2ccccc21</smiles>

15

\footnotetext{
${ }^{[1]}$ a) Fernandez Gonzalez, D.; Brand, J. P.; Waser, J. Chem. Eur. J. 2010, 16, 9457. b) Kraszkiewicz, L.; Skulski, L. Arkivoc. 2003, 6, 120 .
} 
Following a reported procedure, ${ }^{[2]}$ 1-hydroxy-1,2-benziodoxol-3-(1H)-one (14, 10.3 g, 39.1 mmol, 1.00 equiv.) was suspended in acetic anhydride $(35 \mathrm{~mL})$ and heated to reflux for 30 minutes. The resulting clear, slightly yellow solution was slowly let to warm up to room temperature and then cooled to $0{ }^{\circ} \mathrm{C}$ for 30 minutes. The white suspension was filtered and the filtrate was again cooled to $0{ }^{\circ} \mathrm{C}$ for 30 minutes. The suspension was once again filtered and the combined two batches of solid product were washed with hexane $(2 \times 20 \mathrm{~mL})$ and dried in vacuo affording 15 (10.8 g, $35.3 \mathrm{mmol}, 90 \%)$ as a white solid. ${ }^{1} \mathrm{H} \mathrm{NMR}\left(\mathrm{CDCl}_{3}, 400 \mathrm{MHz}\right): \delta$ $8.24(\mathrm{dd}, 1 \mathrm{H}, J=7.6,1.6 \mathrm{~Hz}, \operatorname{Ar} H), 8.00(\mathrm{dd}, 1 \mathrm{H}, J=8.3,1.0 \mathrm{~Hz}, \operatorname{Ar} H), 7.92$ (ddd, $1 \mathrm{H}, J=$ 8.4, 7.2, 1.6 Hz, ArH), $7.71(\mathrm{td}, 1 \mathrm{H}, J=7.3,1.1 \mathrm{~Hz}, \mathrm{Ar} H), 2.25\left(\mathrm{~s}, 3 \mathrm{H}, \mathrm{COCH}_{3}\right) .{ }^{13} \mathrm{C} \mathrm{NMR}$ $\left(\mathrm{CDCl}_{3}, 100 \mathrm{MHz}\right): \delta 176.5,168.2,136.2,133.3,131.4,129.4,129.1,118.4,20.4$. The values of the NMR spectra are in accordance with reported literature data. ${ }^{[2]}$

\section{1-Cyano-1,2-benziodoxol-3-(1H)-one $(6)$}

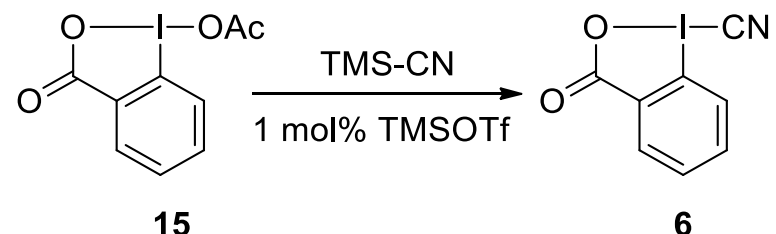

Following a reported procedure, ${ }^{[3]}$ 1-acetoxy-1,2-benziodoxol-3-(1H)-one $(\mathbf{1 5}, 11.8 \mathrm{~g}, 38.6$ mmol, 1.00 eq.) was dissolved under nitrogen in dry dichloromethane (200 mL). To the clear colorless solution was added via syringe trimethylsilyl cyanide (TMS-CN, $10 \mathrm{~mL}, 77 \mathrm{mmol}$, 2.00 eq.) over a five minute time period, then trimethylsilyl trifluoromethanesulfonate (TMSOTf, $70 \mu \mathrm{L}, 0.386 \mathrm{mmol}, 0.01$ equiv.). Precipitation occurred within $5 \mathrm{~min}$ and the reaction mixture was stirred at room temperature and under nitrogen for $30 \mathrm{~min}$ to ensure the completion of the reaction. The resulting thick white suspension was diluted with hexane $(5 \mathrm{~mL})$ before being filtered and the solid was washed with hexane $(3 \times 20 \mathrm{~mL})$ and dried in vacuo affording $6(10.3 \mathrm{~g}, 37.7 \mathrm{mmol}, 98 \%)$ as a white solid. ${ }^{1} \mathrm{H}$ NMR (DMSO- $\left.d_{6}, 400 \mathrm{MHz}\right): \delta 8.29$ (d, $J=$ $8.3 \mathrm{~Hz}, 1 \mathrm{H}, \operatorname{Ar} H), 8.13(\mathrm{dd}, J=7.4,1.7 \mathrm{~Hz}, 1 \mathrm{H}, \operatorname{Ar} H), 8.06-7.97(\mathrm{~m}, 1 \mathrm{H}, \operatorname{Ar} H), 7.88(\mathrm{t}, J=$ $7.3 \mathrm{~Hz}, 1 \mathrm{H}, \mathrm{ArH}) .{ }^{13} \mathrm{C}$ NMR (DMSO- $d_{6}, 100 \mathrm{MHz}$ ): $\delta 166.7,136.5,132.0,131.9,130.2,127.8$, 117.5, 87.9. IR v 3157 (w), 3093 (w), 2160 (w), 1629 (s), 1562 (m), 1439 (m), 1321 (s), 1298 (s), $1148(\mathrm{~m}), 839(\mathrm{~m}), 747$ (s). The characterization data is in accordance with reported literature values. ${ }^{[3]}$

\footnotetext{
${ }^{[2]}$ Eisenberger, P.; Gischig, S.; Togni, A. Chem. Eur. J. 2006, 12, 2579.

${ }^{[3]}$ Chen, M.; Huang, Z. T.; Zheng, Q. Y. Org. Biomol. Chem. 2015, 13, 8812.
} 


\section{1-Acetoxy-3,3-dimethyl-3-(1H)-1,2-benziodoxole (17)}

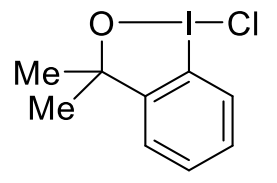

16

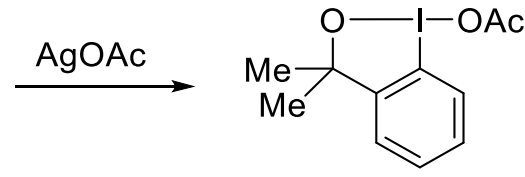

17

Following a reported procedure, ${ }^{[2]}$ 1-chloro-3,3-dimethyl-3-(1H)-1,2-benziodoxole ${ }^{[4]}(\mathbf{1 6}, 3.10$ g, $10.5 \mathrm{mmol}, 1.00$ eq.) and silver acetate (1.83 g, $11.0 \mathrm{mmol}, 1.05$ eq.) were suspended under nitrogen in dry acetonitrile $(30 \mathrm{~mL})$. The mixture was stirred in the dark at room temperature for 15 hours. Filtration of the precipitated silver chloride followed by solvent removal in vacuo yielded compound 17 (2.98 g, $9.31 \mathrm{mmol}, 89 \%)$ as a white solid. ${ }^{1} \mathrm{H} \mathrm{NMR}\left(\mathrm{CDCl}_{3}, 400 \mathrm{MHz}\right)$ : $\delta 7.79(\mathrm{dd}, J=8.0,1.3 \mathrm{~Hz}, 1 \mathrm{H}, \mathrm{ArH}), 7.52-7.41$ (m, $2 \mathrm{H}, \mathrm{ArH}), 7.17$ (dd, $J=7.4,1.6 \mathrm{~Hz}, 1 \mathrm{H}$,

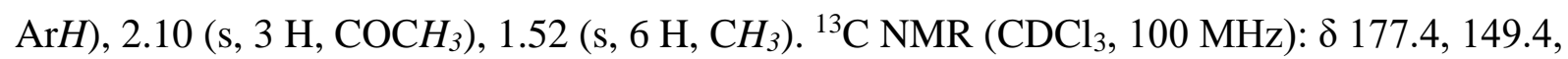
$130.5,130.0,129.9,126.3,115.8,84.6,29.3,21.6$. The characterization data is in accordance with reported literature values. ${ }^{[2]}$

\section{1-Cyano-3,3-dimethyl-3-(1H)-1,2-benziodoxole (6b)}

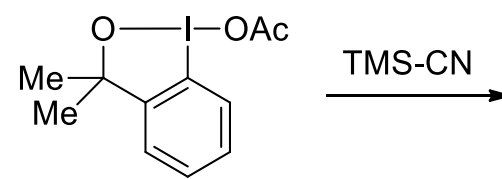

17<smiles>CC1(C)OI(C#N)c2ccccc21</smiles>

6b

To a solution consisting of 1-acetoxy-3,3-dimethyl-3-(1H)-1,2-benziodoxole (17, $2.00 \mathrm{~g}, 6.25$ mmol, 1.00 equiv.) and dry dichloromethane $(15 \mathrm{~mL})$ was added dropwise trimethylsilyl cyanide (TMS-CN, $1.71 \mathrm{~mL}, 12.5 \mathrm{mmol}, 2.00 \mathrm{eq}$.) at room temperature under nitrogen. The clear colorless solution was stirred at room temperature for 20 hours. Solvent removal afforded a white solid, which was suspended in pentane $(10 \mathrm{~mL})$, filtered and dried in vacuo affording pure compound $\mathbf{6 b}(1.73 \mathrm{~g}, 6.03 \mathrm{mmol}, 96 \%)$ as a white solid. $\mathrm{R}_{f}($ pentane:EtOAc 7:3) $=0.54$. ${ }^{1} \mathrm{H}$ NMR $\left(\mathrm{CDCl}_{3}, 400 \mathrm{MHz}\right): \delta 8.05(\mathrm{~d}, J=8.3 \mathrm{~Hz}, 1 \mathrm{H}, \mathrm{Ar} H), 7.62(\mathrm{t}, J=7.3 \mathrm{~Hz}, 1 \mathrm{H}, \mathrm{Ar} H)$, 7.58-7.49 (m, $1 \mathrm{H}, \mathrm{ArH}), 7.33(\mathrm{~d}, J=7.5 \mathrm{~Hz}, 1 \mathrm{H}, \mathrm{ArH}), 1.48\left(\mathrm{~s}, 6 \mathrm{H}, \mathrm{CH}_{3}\right) .{ }^{13} \mathrm{C} \mathrm{NMR}\left(\mathrm{CDCl}_{3}\right.$, $100 \mathrm{MHz}): \delta 148.1,131.7,131.0,128.3,126.9,111.6,98.0,80.4,30.3$. IR $v 2974(w), 2925$

\footnotetext{
${ }^{[4]}$ This commercially available compound can also be synthesized following the practical procedure by Matousek,
} V.; Pietrasiak, E.; Schwenk, R.; Togni, A. J. Org. Chem. 2013, 78, 6763. 
(w), 2139 (w), 1461 (m), 1436 (m), 1251 (m), 1160 (s), 1003 (w), 954 (s), 869 (m), 761 (s). The characterization data is in accordance with reported literature values. ${ }^{[5]}$

4-Tert-butyl-2-iodobenzoic acid (19)<smiles>Cc1ccc(C(C)(C)C)cc1I</smiles>

18

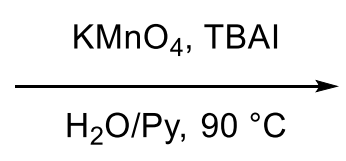

19

From a modification of known procedures $^{[2]}$, to the solution of 4-tert-butyl-2-iodo-1methylbenzene 18 (6.8 g, $25 \mathrm{mmol}, 1$ equiv) in $\mathrm{H}_{2} \mathrm{O} /$ pyridine $(85 \mathrm{ml}: 106 \mathrm{ml})$, was added $\mathrm{KMnO}_{4}$ (15.6 g, $99.0 \mathrm{mmol}, 4$ equiv) and $\mathrm{nBuN}_{4} \mathrm{I}$ (137 mg, $0.371 \mathrm{mmol}, 1.5 \mathrm{~mol} \%$ ). The purple mixture was heated to reflux for 4 days. It was then allowed to cool down to room temperature and the solids were filtered off through a pad of celite, which was then washed with aq. $\mathrm{NaOH}$ $(2.0 \mathrm{M})$. Most of the pyridine was removed from the filtrate by evaporation under reduced pressure. The aqueous residue was washed with diethyl ether $(3 \times 100 \mathrm{~mL})$ and it then acidified until $\mathrm{pH}<2$ by careful addition of aq. $\mathrm{HCl}(37 \% \mathrm{v} / \mathrm{v})$. The aqueous layer was extracted with DCM (3 x $100 \mathrm{~mL})$ and the combined organic extracts were dried over $\mathrm{MgSO}_{4}$, filtered and concentrated under vacuum to provide the 4-(tert-butyl)-2-iodobenzoic acid 19 (3.88 g, 12.8 mmol, $52 \%)$ as a yellowish solid. ${ }^{1} \mathrm{H}-\mathrm{NMR}\left(400 \mathrm{MHz}, \mathrm{CDCl}_{3}\right): \delta 8.04(\mathrm{~d}, J=1.8 \mathrm{~Hz}, 1 \mathrm{H}, \mathrm{Ar} H)$, $7.97(\mathrm{~d}, J=8.2 \mathrm{~Hz}, 1 \mathrm{H}, \mathrm{ArH}), 7.45(\mathrm{dd}, J=8.2,1.8 \mathrm{~Hz}, 1 \mathrm{H}, \mathrm{Ar} H), 1.31$ (s, 9H, CH3). ${ }^{13} \mathrm{C}-\mathrm{NMR}$ (100 MHz, $\mathrm{CDCl} 3): \delta 171.6,158.0,139.6,132.3,130.2,125.5,95.5,35.1,31.1$. The characterization data is in accordance with reported literature values. ${ }^{[3]}$

\section{4-Tert-butyl -1-hydroxy-1,2-benziodoxol-3-(1H)-one (20)}

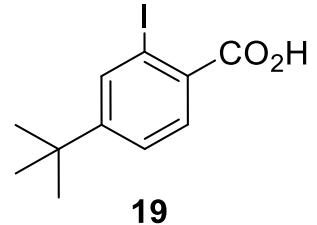

19

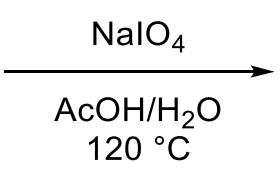

$120^{\circ} \mathrm{C}$<smiles>CC(C)(C)c1ccc2c(c1)I(O)OC2=O</smiles>

20

Following a reported procedure, ${ }^{[3]} \mathrm{NaIO}_{4}(2.67 \mathrm{~g}, 12.5 \mathrm{mmol}, 1.05$ equiv) and 4-(tert-butyl)-2iodobenzoic acid (19) (3.80 g, $12.5 \mathrm{mmol}, 1.00$ equiv) were suspended in $30 \%$ (v:v) aq. AcOH

${ }^{[5]}$ Zhdankin, V. V.; Kuehl, C. J.; Krasutsky, A. P.; Bolz, J. T.; Mismash, B.; Woodward, J. K.; Simonsen, A. J. Tetrahedron Lett. 1995, 36, 7975. 
$(24 \mathrm{~mL})$. The mixture was vigorously stirred and refluxed $\left(140^{\circ} \mathrm{C}\right)$ for $4 \mathrm{~h}$. The reaction mixture was then allowed to cool to room temperature, protecting it from light. The bottom of the flask was scratched with a spatual in order to induce the crystallization. The flask was then cooled to $-18^{\circ} \mathrm{C}$ (by transferring it into a freezer) and kept at this temperature for 3 hours. The precipitated white crystalline solid was then collected by filtration and washed with several portions of pentane to provide 20 (3.47 g, $10.8 \mathrm{mmol}, 87 \%)$ as a white solid. ${ }^{1} \mathrm{H}-\mathrm{NMR}$ (400 MHz, DMSO): $\delta 8.00(\mathrm{~s}, 1 \mathrm{H}, \mathrm{OH}), 7.92(\mathrm{~d}, J=7.8 \mathrm{~Hz}, 1 \mathrm{H}, \operatorname{Ar} H), 7.81(\mathrm{~s}, 1 \mathrm{H}, \operatorname{Ar} H), 7.74(\mathrm{~d}, J=7.8 \mathrm{~Hz}, 1 \mathrm{H}$, $\mathrm{ArH}), 1.35$ (s, 9H, $\left.\mathrm{CH}_{3}\right) .{ }^{13} \mathrm{C}-\mathrm{NMR}$ (100 MHz, DMSO): $\delta$ 168.6, 158.8, 131.8, 130.0, 128.8, $123.3,121.5,36.5,31.8$. The reported values correspond to the ones in literature. ${ }^{[3]}$

4-Tert-butyl-1-acetoxy-1,2-benziodoxol-3-(1H)-one (21)<smiles>CC(C)(C)c1ccc2c(c1)I(O)OC2=O</smiles>

20<smiles>CC(=O)OI1OC(=O)c2ccc(C(C)(C)C)cc21</smiles>

21

Following a reported procedure, ${ }^{[2]}$ 1-hydroxy-6-(tert-butyl)-1,2-benziodoxol-3-(1H)-one (20, $3.47 \mathrm{~g}, 10.8 \mathrm{mmol}, 1.00$ equiv.) was suspended in acetic anhydride (10 mL) and heated to reflux for 30 minutes. The resulting clear, slightly yellow solution was slowly let to warm up to room temperature and then cooled to $0{ }^{\circ} \mathrm{C}$ for 30 minutes. The white suspension was filtered and the filtrate was again cooled to $0{ }^{\circ} \mathrm{C}$ for 30 minutes. The suspension was once again filtered and the combined two batches of solid product were washed with hexane $(2 \times 10 \mathrm{~mL})$ and dried in vacuo affording 21 (2.95 g, $8.15 \mathrm{mmol}, 75 \%)$ as a white solid. ${ }^{1} \mathrm{H}-\mathrm{NMR}\left(400 \mathrm{MHz}, \mathrm{CDCl}_{3}\right): \delta$ $8.14(\mathrm{~d}, J=8 \mathrm{~Hz}, 1 \mathrm{H}, \operatorname{Ar} H), 7.94(\mathrm{~d}, J=1.6 \mathrm{~Hz}, 1 \mathrm{H}, \mathrm{Ar} H), 7.71(\mathrm{dd}, J=1.6,8 \mathrm{~Hz}, 1 \mathrm{H}, \operatorname{Ar} H)$, 2.26 (s, 3H, $\left.\mathrm{OCOCH}_{3}\right), 1.41\left(\mathrm{~s}, 9 \mathrm{H}, \mathrm{CH}_{3}\right) .{ }^{13} \mathrm{C}-\mathrm{NMR}\left(100 \mathrm{MHz}, \mathrm{CDCl}_{3}\right): \delta 176.4,168.5,161.2$, 133.0, 129.1, 126.4, 125.8, 119.2, 36.4, 31.3, 20.5. The values of the NMR spectra are in accordance with reported literature data. ${ }^{[3]}$

\section{4-Tert-butyl-1-acetoxy-1,2-benziodoxol-3-(1H)-one (6c)}<smiles>CC(=O)OI1OC(=O)c2ccc(C(C)(C)C)cc21</smiles>

21

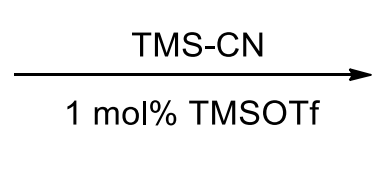<smiles>CC(C)(C)c1ccc2c(c1)I(C#N)OC2=O</smiles>

6c 
Following a reported procedure, ${ }^{[3]} 1$-acetoxy-4-tert-butyl-1,2-benziodoxol-3-(1H)-one (21, 2.8 g, $7.7 \mathrm{mmol}, 1.00$ eq.) was dissolved under nitrogen in dry dichloromethane ( $77 \mathrm{~mL})$. To the clear colorless solution was added via syringe trimethylsilyl cyanide (TMS-CN, $1.93 \mathrm{~mL}, 15.4$ mmol, 2.00 eq.) over a five minute time period, then trimethylsilyl trifluoromethanesulfonate (TMS-OTf, $14 \mu \mathrm{L}, 0.077 \mathrm{mmol}, 0.01$ equiv.). Precipitation occurred within $5 \mathrm{~min}$ and the reaction mixture was stirred at room temperature and under nitrogen for $30 \mathrm{~min}$ to ensure the completion of the reaction. The resulting thick white suspension was diluted with pentane (5 $\mathrm{mL})$ before being filtered and the solid was washed with pentane $(3 \times 20 \mathrm{~mL})$ and dried in vacuo affording 6c (2.48 g, $7.53 \mathrm{mmol}, 97 \%)$ as a white solid. ${ }^{1} \mathrm{H}-\mathrm{NMR}\left(400 \mathrm{MHz}, \mathrm{CDCl}_{3}\right): \delta 8.46$ (s, $1 \mathrm{H}, \mathrm{ArH}), 8.25(\mathrm{~d}, J=7.6 \mathrm{~Hz}, 1 \mathrm{H}, \mathrm{Ar} H), 7.84(\mathrm{~d}, J=8.0 \mathrm{~Hz}, 1 \mathrm{H}, \mathrm{Ar} H), 1.44$ (s, 9H, CH$) .{ }^{13} \mathrm{C}-$ NMR (100 MHz, $\left.\mathrm{CDCl}_{3}\right): \delta 168.7,162.1,132.9,130.0,127.5,124.9,117.4,85.6,36.7,31.3$. HRMS (ESI+) calced for $\left[\mathrm{C}_{12} \mathrm{H}_{13} \mathrm{O}_{2} \mathrm{NI}\right]^{+}: 329.9986$, found: 329.9982 . The characterization data is in accordance with reported literature values. ${ }^{[3]}$

\section{2-Iodosyl-5-nitrobenzoic acid (22) and 2-iodosyl-3-nitrobenzoic acid (23)}<smiles>O=C(O)c1ccccc1I</smiles>

13

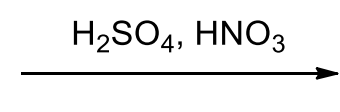

22<smiles>O=C1OI(O)c2ccc([N+](=O)[O-])cc21</smiles><smiles>O=C1OI(O)c2c1cccc2[N+](=O)[O-]</smiles>

23

Following a reported procedure, ${ }^{[6]}$ fuming nitric acid $(3.3 \mathrm{~mL})$ was added to 2-iodobenzoic acid (13) $\left(5.0 \mathrm{~g}, 20 \mathrm{mmol}, 1.0\right.$ equiv) in concentrated $\mathrm{H}_{2} \mathrm{SO}_{4}(6.7 \mathrm{~mL})$. The reaction was equipped with a cooler and a nitrous vapor trap and was heated at $100{ }^{\circ} \mathrm{C}$ for $1 \mathrm{~h}$. The reaction mixture was then poured in ice-water and filtered. The resulting solid was refluxed in water $(50 \mathrm{~mL})$ and filtered. A second crop of precipitate was filtered from the mother liquors. Both solids were combined, washed with acetone $(10 \mathrm{~mL})$ and dried under vacuum to afford $22(2.19 \mathrm{~g}, 7.10$ mmol, $36 \%$ ). The mother liquors were reduced to one third and then kept at $4{ }^{\circ} \mathrm{C}$, the resulting precipitate was filtered, washed with acetone $(10 \mathrm{~mL})$ and dried under vacuum to afford 23 (630 mg, $2.04 \mathrm{mmol}, 10 \%$ ). 22: ${ }^{1} \mathrm{H}$ NMR (400 MHz, $\left.\left(\mathrm{CD}_{3}\right)_{2} \mathrm{SO}\right): \delta 8.73$ (dd, $J=8.8,2.6 \mathrm{~Hz}$, $1 \mathrm{H}, \operatorname{Ar} H), 8.58$ (d, $J=2.4 \mathrm{~Hz}, 1 \mathrm{H}, \operatorname{Ar} H), 8.54$ (br s, $1 \mathrm{H}, \mathrm{OH}), 8.11$ (d, $J=8.8 \mathrm{~Hz}, 1 \mathrm{H}, \operatorname{Ar} H$ ). 23: ${ }^{1} \mathrm{H}$ NMR (400 MHz, $\left.\left(\mathrm{CD}_{3}\right)_{2} \mathrm{SO}\right): \delta 7.92(\mathrm{dd}, J=7.9,1.5 \mathrm{~Hz}, 1 \mathrm{H}, \operatorname{Ar} H), 7.79(\mathrm{~m}, 1 \mathrm{H}, \operatorname{Ar} H)$, $7.67(\mathrm{~m}, 1 \mathrm{H}, \mathrm{Ar} H)$. The reported values correspond to the ones in literature. ${ }^{[6]}$

\footnotetext{
${ }^{[6]}$ Brand, J. P.; Chevalley, C.; Scopelliti, R.; Waser, J. Chem. Eur. J. 2012, 18, 5655.
} 


\section{5-Nitro-1-Acetoxy-1,2-benziodoxol-3-(1H)-one (24)}<smiles>O=C1OI(O)c2ccc([N+](=O)[O-])cc21</smiles>

22<smiles>CC(=O)O[C@H]1COC(=O)c2cc([N+](=O)[O-])ccc21</smiles>

24

Following a reported procedure, ${ }^{[2]}$ 5-nitro-1-hydroxy-1,2-benziodoxol-3-(1H)-one (22, $6.55 \mathrm{~g}$, $21.2 \mathrm{mmol}, 1.00$ eq.) was suspended in acetic anhydride $(18 \mathrm{~mL})$ and heated to reflux for 30 minutes. The resulting clear, slightly yellow solution was slowly let to warm up to room temperature and then cooled to $0{ }^{\circ} \mathrm{C}$ for 30 minutes. The white suspension was filtered and the filtrate was again cooled to $0{ }^{\circ} \mathrm{C}$ for 30 minutes. The suspension was once again filtered and the combined two batches of solid product were washed with hexane $(2 \times 20 \mathrm{~mL})$ and dried in vacuo affording 24 (5.88 g, $16.7 \mathrm{mmol}, 79 \%$ ) as a white solid. ${ }^{1} \mathrm{H}$ NMR(400 MHz, Chloroformd) $\delta 9.04(\mathrm{~d}, J=2.5 \mathrm{~Hz}, 1 \mathrm{H}, \mathrm{Ar} H), 8.71(\mathrm{dd}, J=9.0,2.5 \mathrm{~Hz}, 1 \mathrm{H}, \mathrm{ArH}), 8.27(\mathrm{~d}, J=8.9 \mathrm{~Hz}, 1 \mathrm{H}$, $\operatorname{ArH}), 2.30(\mathrm{~s}, 3 \mathrm{H}, \mathrm{OC}(\mathrm{O}) M e)$. The values of the NMR spectra are in accordance with reported literature data. ${ }^{[2]}$

\section{5-Nitro-1-Cyano-1,2-benziodoxol-3-(1H)-one (6d)}<smiles>CC(=O)OI1COC(=O)c2cc([N+](=O)[O-])ccc21</smiles><smiles>C[As](C)O[Na]</smiles>

Following a reported procedure, ${ }^{[3]}$ 1-acetoxy-1,2-benziodoxol-3-(1H)-one $(\mathbf{2 4}, 351 \mathrm{mg}, 1.00$ mmol, 1.00 eq.) was dissolved under nitrogen in dry dichloromethane $(7.0 \mathrm{~mL})$. To the clear colorless solution was added via syringe trimethylsilyl cyanide (TMS-CN, 0.27 mL, $2.0 \mathrm{mmol}$, 2.00 eq.) over a five minute time period. then trimethylsilyl trifluoromethanesulfonate (TMSOTf, $1.8 \mu \mathrm{L}, 10 \mu \mathrm{mol}, 0.01$ equiv.). Precipitation occurred within $5 \mathrm{~min}$ and the reaction mixture was stirred at room temperature and under nitrogen for 30 min to ensure the completion of the reaction. The resulting thick white suspension was diluted with hexane $(5 \mathrm{~mL})$ before being filtered and the solid was washed with hexane $(3 \times 20 \mathrm{~mL})$ and dried in vacuo affording 6d (273 mg, $0.859 \mathrm{mmol}, 86 \%)$ as a white solid. ${ }^{1} \mathrm{H}$ NMR(400 MHz, DMSO-d6) $\delta 8.77$ (dd, $J$ $=8.9,2.7 \mathrm{~Hz}, 1 \mathrm{H}, \operatorname{Ar} H), 8.64(\mathrm{~d}, J=2.6 \mathrm{~Hz}, 1 \mathrm{H}, \operatorname{Ar} H), 8.54(\mathrm{~d}, J=8.9 \mathrm{~Hz}, 1 \mathrm{H}, \operatorname{Ar} H)$. The characterization data is in accordance with reported literature values. ${ }^{[3]}$ 


\section{5-Fluoro-1-Hydroxy-1,2-benziodoxol-3-(1H)-one (26)}<smiles>O=C(O)c1cc(F)ccc1I</smiles>

25

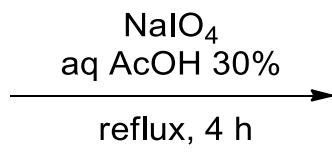

26

Following a reported procedure, ${ }^{[6]} \mathrm{NaIO}_{4}(760 \mathrm{mg}, 3.55 \mathrm{mmol}, 1.05$ equiv) and 5-fluoro-2iodobenzoic acid (25) (900 mg, $3.38 \mathrm{mmol}, 1.00$ equiv) were suspended in $30 \%$ (v:v) aq. AcOH $(1.8 \mathrm{~mL}) / \mathrm{H}_{2} \mathrm{O}(4.5 \mathrm{~mL})$. The mixture was vigorously stirred and refluxed for $4 \mathrm{~h}$. The reaction mixture was then diluted with cold water $(180 \mathrm{~mL})$ and allowed to cool to $\mathrm{rt}$, protecting it from light. After $1 \mathrm{~h}$, the crude product was collected by filtration, washed on the filter with ice water $(3 \times 10 \mathrm{~mL})$ and acetone $(3 \times 10 \mathrm{~mL})$, and air-dried in the dark to give the pure product $\mathbf{2 6}(908$ $\mathrm{mg}, 3.22 \mathrm{mmol}, 95 \%)$ as a colorless solid. ${ }^{1} \mathrm{H} \mathrm{NMR}\left(400 \mathrm{MHz},\left(\mathrm{CD}_{3}\right)_{2} \mathrm{SO}\right) \delta 8.25$ (bs, $\left.1 \mathrm{H}, \mathrm{OH}\right)$, $7.90-7.78(\mathrm{~m}, 2 \mathrm{H}, \mathrm{Ar} H), 7.75(\mathrm{dd}, J=8.4,2.5 \mathrm{~Hz}, 1 \mathrm{H}, \mathrm{Ar} H) .{ }^{13} \mathrm{C} \mathrm{NMR}\left(100 \mathrm{MHz},\left(\mathrm{CD}_{3}\right)_{2} \mathrm{SO}\right)$ $\delta 166.7(\mathrm{~d}, J=2.6 \mathrm{~Hz}), 164.0(\mathrm{~d}, J=248.3 \mathrm{~Hz}), 134.2(\mathrm{~d}, J=7.5 \mathrm{~Hz}), 128.5(\mathrm{~d}, J=8.7 \mathrm{~Hz})$, $121.98(\mathrm{~d}, J=23.9 \mathrm{~Hz}), 117.4(\mathrm{~d}, J=23.6 \mathrm{~Hz}), 114.4$. The reported values correspond to the ones in literature. ${ }^{[6]}$

\section{5-Fluoro-1-Acetoxy-1,2-benziodoxol-3-(1H)-one (27)}<smiles>O=C1OI(O)c2ccc(F)cc21</smiles>

26<smiles>CCO[C@H]1CO[In](OC(C)=O)c2ccc(F)cc21</smiles>

27

Following a reported procedure ${ }^{[6]}$ hypervalent iodine precursor 26 (800 mg, $2.84 \mathrm{mmol}, 1.00$ equiv.) was suspended in acetic anhydride (2.80 mL, $29.7 \mathrm{mmol}, 10.5$ equiv) and heated to reflux for 30 minutes. The resulting clear, slightly yellow solution was slowly let to cool down to room temperature and then cooled to $0{ }^{\circ} \mathrm{C}$ for 30 minutes. The white suspension was filtered and the filtrate was again cooled to $0{ }^{\circ} \mathrm{C}$ for 30 minutes. The suspension was once again filtered and the combined two batches of solid product were washed with hexane $(2 \times 20 \mathrm{~mL})$ and dried in vacuo affording the corresponding OAc hypervalent iodine reagent 27 (825 mg, $2.55 \mathrm{mmol}$, $90 \%)$ as a white solid. ${ }^{1} \mathrm{H}$ NMR $\left(400 \mathrm{MHz}, \mathrm{CDCl}_{3}\right) \delta 8.01-7.93(\mathrm{~m}, 2 \mathrm{H}, \mathrm{ArH}), 7.64$ (ddd, $J=$ 9.1, 7.7, 2.9 Hz, 1H, ArH), 2.26 (s, 3H, OC(O)Me). $\left.{ }^{13} \mathrm{C} \mathrm{NMR} \mathrm{(100} \mathrm{MHz,} \mathrm{CDCl}_{3}\right) \delta 176.4,166.7$ $(\mathrm{d}, J=2.9 \mathrm{~Hz}), 165.0(\mathrm{~d}, J=254.5 \mathrm{~Hz}), 131.7(\mathrm{~d}, J=8.0 \mathrm{~Hz}), 131.0(\mathrm{~d}, J=8.1 \mathrm{~Hz}), 123.7(\mathrm{~d}$, 
$J=24.0 \mathrm{~Hz}), 120.0(\mathrm{~d}, J=24.3 \mathrm{~Hz}), 111.2(\mathrm{~d}, J=2.3 \mathrm{~Hz}), 20.2$.The values of the NMR spectra are in accordance with reported literature data, with small differences in chemical shifts for

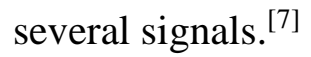

\section{5-Fluoro-1-Cyano-1,2-benziodoxol-3-(1H)-one (6e)}

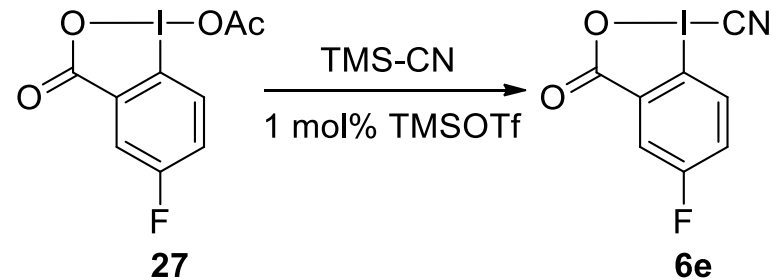

Following a reported procedure, ${ }^{[3]}$ 5-Fluoro-1-acetoxy-1,2-benziodoxol-3-(1H)-one $(\mathbf{2 7}, 750 \mathrm{~g}$, $2.31 \mathrm{mmol}, 1.00$ equiv.) was dissolved under nitrogen in dry dichloromethane (15 mL). To the clear colorless solution was added via syringe trimethylsilyl cyanide (TMS-CN, $0.62 \mathrm{~mL}, 4.6$ mmol, 2.0 equiv.), over a five minute time period, then trimethylsilyl trifluoromethanesulfonate (TMS-OTf, $4.2 \mu \mathrm{L}, 23 \mu \mathrm{mol}, 0.010$ equiv.). Precipitation occurred within $5 \mathrm{~min}$ and the reaction mixture was stirred at room temperature and under nitrogen for $30 \mathrm{~min}$ to ensure the completion of the reaction. The resulting thick white suspension was diluted with hexane $(5 \mathrm{~mL})$ before being filtered and the solid was washed with hexane $(3 \times 20 \mathrm{~mL})$ and dried in vacuo affording 6e (610 mg, $2.10 \mathrm{mmol}, 91 \%)$ as a white solid. Mp: $181.1-184.1^{\circ} \mathrm{C}$ (decomp). ${ }^{1} \mathrm{H}$ NMR (400 $\left.\mathrm{MHz}, \mathrm{DMSO}-d_{6}\right) \delta 8.25(\mathrm{dd}, J=8.9,4.2 \mathrm{~Hz}, 1 \mathrm{H}, \mathrm{Ar} H), 7.99-7.75(\mathrm{~m}, 2 \mathrm{H}, \mathrm{Ar} H) .{ }^{13} \mathrm{C} \mathrm{NMR}$ $\left(100 \mathrm{MHz}, \mathrm{DMSO}-d_{6}\right) \delta 165.3(\mathrm{~d}, J=2.4 \mathrm{~Hz}), 164.6(\mathrm{~d}, J=251.5 \mathrm{~Hz}), 133.1(\mathrm{~d}, J=7.7 \mathrm{~Hz})$, $130.1(\mathrm{~d}, J=8.9 \mathrm{~Hz}), 123.8(\mathrm{~d}, J=24.5 \mathrm{~Hz}), 118.4(\mathrm{~d}, J=24.1 \mathrm{~Hz}), 111.4,87.4$. IR (solid) 3870 (s), 3740 (s), 3686 (s), 3620 (m), 3435 (w), 3335 (w), 3227 (w), 3109 (w), 2988 (w), 2914 (w), 2360 (m), 2162 (w), 2005 (w), 1926 (w), 1865 (w), 1739 (m), 1702 (m), 1647 (m), 1518 (s), 1457 (m), 1419 (m), 1306 (m), 1141 (w), 1025 (s), 823 (w). HRMS (ESI) calcd for $\mathrm{C}_{8} \mathrm{H}_{4} \mathrm{FINO}_{2}{ }^{+}[\mathrm{M}+\mathrm{H}]^{+}$291.9265; found 291.9270.

\section{1-Hydroxy-1,2-naphthiodoxol-3-(1H) (29)}<smiles>O=C(O)c1cc2ccccc2cc1I</smiles>

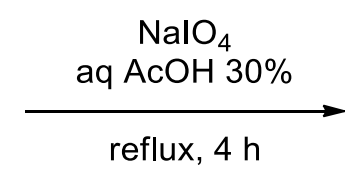<smiles>O=C1OI(O)c2cc3ccccc3cc21</smiles>

\footnotetext{
${ }^{[7]}$ Iinuma, M.; Moriyama, K.; Togo, H. Eur. J. Org. Chem. 2014, 772.
} 
Following a reported procedure, ${ }^{[3]} \mathrm{NaIO}_{4}(1.9 \mathrm{~g}, 8.8 \mathrm{mmol}, 1.05$ equiv) and 3-iodo-2-naphthoic acid (28) (2.5 g, $8.4 \mathrm{mmol}, 1.00$ equiv) were suspended in $30 \%$ (v:v) aq. AcOH (27 mL). The mixture was vigorously stirred and refluxed for $4 \mathrm{~h}$. The reaction mixture was then diluted with cold water $(180 \mathrm{~mL})$ and allowed to cool to rt, protecting it from light. After $1 \mathrm{~h}$, the crude product was collected by filtration, washed on the filter with ice water $(3 \times 8 \mathrm{~mL})$ and acetone ( $3 \times 8 \mathrm{~mL})$, and air-dried in the dark to give the pure product $29(2.2 \mathrm{~g}, 6.9 \mathrm{mmol}, 82 \%)$ as a colorless solid. ${ }^{1} \mathrm{H}-\mathrm{NMR}$ (400 MHz, DMSO): $\delta 8.67$ (s, 1H, OH), 8.38 (s, 1H, ArH), 8.28 (d, $J$ $=8.0 \mathrm{~Hz}, 1 \mathrm{H}, \mathrm{ArH}), 8.18-8.20(\mathrm{~m}, 2 \mathrm{H}, \mathrm{ArH}), 7.71-7.78(\mathrm{~m}, 2 \mathrm{H}, \mathrm{ArH}) .{ }^{13} \mathrm{C}-\mathrm{NMR}(100 \mathrm{MHz}$, $\left.\mathrm{CDCl}_{3}\right): \delta 168.5,136.6,133.5,132.5,130.0,129.6,128.8,128.7,128.6,127.1,116.6$. The reported values correspond to the ones in literature. ${ }^{[3]}$

\section{1-Acetoxy-1,2-naphthiodoxol-3-(1H)-one (30)}<smiles>O=C1OI(O)c2cc3ccccc3cc21</smiles>

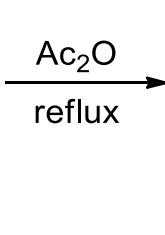<smiles>CC(=O)OI1Cc2cc3ccccc3cc2C(=O)O1</smiles>

Following a reported procedure, ${ }^{[3]} 1$-hydroxy-1,2-naphthiodoxol-3-(1H)-one e $(\mathbf{2 9}, 1.57 \mathrm{~g}, 5.00$ mmol, 1.00 equiv.) was suspended in acetic anhydride $(5 \mathrm{~mL})$ and heated to reflux for 30 minutes. The resulting clear, slightly yellow solution was slowly let to warm up to room temperature and then cooled to $0{ }^{\circ} \mathrm{C}$ for 30 minutes. The white suspension was filtered and the filtrate was again cooled to $0{ }^{\circ} \mathrm{C}$ for 30 minutes. The suspension was once again filtered and the combined two batches of solid product were washed with hexane $(2 \times 5 \mathrm{~mL})$ and dried in vacuo affording 30 (1.48 g, $4.17 \mathrm{mmol}, 83 \%)$ as a white solid. ${ }^{1} \mathrm{H}-\mathrm{NMR}\left(400 \mathrm{MHz}, \mathrm{CDCl}_{3}\right)$ : $\delta$ $8.72(\mathrm{~s}, 1 \mathrm{H}, \operatorname{Ar} H), 8.35$ (s, 1H, ArH), 8.05 (d, $J=8.0 \mathrm{~Hz}, 1 \mathrm{H}, \operatorname{Ar} H), 7.96(\mathrm{~d}, J=8.0 \mathrm{~Hz}, 1 \mathrm{H}$, $\mathrm{ArH}), 7.68-7.77(\mathrm{~m}, 2 \mathrm{H}, \mathrm{ArH}), 2.31\left(\mathrm{~s}, 3 \mathrm{H}, \mathrm{CH}_{3}\right) .{ }^{13} \mathrm{C}-\mathrm{NMR}\left(100 \mathrm{MHz}, \mathrm{CDCl}_{3}\right): \delta 176.7,168.6$, $137.7,134.5,133.6,130.0,129.9,129.8,129.2,128.4,124.6,112.7,20.7$. The values of the NMR spectra are in accordance with reported literature data. ${ }^{[3]}$

\section{1-Cyano-1,2-naphthiodoxol-3-(1H)-one (6f)}

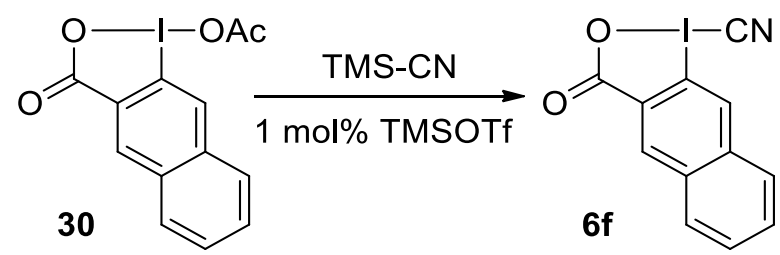


Following a reported procedure, ${ }^{[3]} 1$-acetoxy-1,2-naphthiodoxol-3- $(1 \mathrm{H})$-one $(\mathbf{3 0}, 500 \mathrm{mg}, 1.40$ mmol, 1.00 eq.) was dissolved under nitrogen in dry dichloromethane (14 mL). To the clear colorless solution was added via syringe trimethylsilyl cyanide (TMS-CN, 0.35 mL, $2.8 \mathrm{mmol}$, 2.00 eq.) over a five minute time period, then trimethylsilyl trifluoromethanesulfonate (TMSOTf, $2.5 \mu \mathrm{L}, 0.014 \mathrm{mmol}, 0.01$ equiv.). Precipitation occurred within $5 \mathrm{~min}$ and the reaction mixture was stirred at room temperature and under nitrogen for $30 \mathrm{~min}$ to ensure the completion of the reaction. The resulting thick white suspension was diluted with hexane $(5 \mathrm{~mL})$ before being filtered and the solid was washed with hexane $(3 \times 20 \mathrm{~mL})$ and dried in vacuo affording 6f (421 mg, $1.30 \mathrm{mmol}, 93 \%$ ) as an off-white solid. ${ }^{1} \mathrm{H}-\mathrm{NMR}$ (400 MHz, DMSO): $\delta 8.73$ (d, J $=12.0 \mathrm{~Hz}, 2 \mathrm{H}, \operatorname{Ar} H), 8.27(\mathrm{~d}, J=7.6 \mathrm{~Hz}, 1 \mathrm{H}, \operatorname{Ar} H), 8.19(\mathrm{~d}, J=7.6 \mathrm{~Hz}, 1 \mathrm{H}, \operatorname{Ar} H), 7.75-7.82(\mathrm{~m}$, $2 \mathrm{H}, \mathrm{Ar} H) .{ }^{13} \mathrm{C}-\mathrm{NMR}(100 \mathrm{MHz}, \mathrm{DMSO}): \delta 167.4,137.5,134.3,133.4,130.3,130.2,129.6$, $128.8,128.3,126.7,113.8,88.8$. The characterization data is in accordance with reported literature values. ${ }^{[3]}$ 


\section{Hydantoin synthesis}

\section{Optimization of the reaction:}
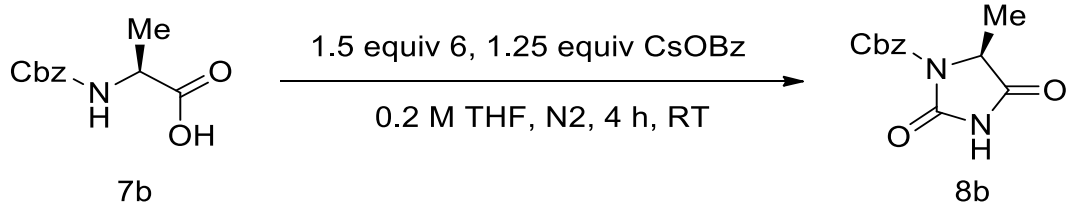

Dry THF $(1.5 \mathrm{~mL})$ was added in a flame dried $5 \mathrm{~mL}$ test tube containing a teflon coated stir bar, the commercially available amino acid $7 \mathbf{b}(67 \mathrm{mg}, 0.30 \mathrm{mmol}, 1.0$ equiv), CBX reagent (6) (123 mg, $0.450 \mathrm{mmol}, 1.5$ equiv) and $\mathrm{CsOBz}$ (95.0 mg, $0.375 \mathrm{mmol}, 1.25$ equiv) under $\mathrm{N}_{2}$ (vaccum / $\mathrm{N}_{2}$ exchange). The resulting mixture was stirred for $4 \mathrm{~h}$ at $\mathrm{rt}$. After completion of the reaction, the reaction mixture concentrated under reduced pressure. Purification was performed by column chromatography (DCM/MeOH) affording the corresponding hydantoin $\mathbf{8 b}$.

Table S1. Optimization of the hydantoin formation.

\begin{tabular}{|c|c|c|c|c|c|}
\hline entry & base & equiv. & solvent & concentration $(\mathrm{M})$ & NMR yield (\%) \\
\hline 1 & $\mathrm{CsOBz}$ & 1.25 & THF & 0.2 & $>95,83^{[b]}$ \\
\hline 2 & $\mathrm{CsOBz}$ & 1.1 & THF & 0.2 & 53 \\
\hline 3 & $\mathrm{CsOBz}$ & 0.2 & THF & 0.2 & 20 \\
\hline 4 & $\mathrm{CsOBz}$ & 1.25 & dioxane & 0.2 & 60 \\
\hline 5 & $\mathrm{CsOBz}$ & 1.25 & MTBE & 0.2 & $<10$ \\
\hline 6 & $\mathrm{CsOBz}$ & 1.25 & EtOAc & 0.2 & 20 \\
\hline 7 & $\mathrm{CsOBz}$ & 1.25 & DCM & 0.2 & 45 \\
\hline 8 & $\mathrm{CsOBz}$ & 1.25 & DMF & 0.2 & 55 \\
\hline 9 & $\mathrm{Cs}_{2} \mathrm{CO}_{3}$ & 1.25 & THF & 0.2 & $<10$ \\
\hline 10 & $\mathrm{CsOAc}$ & 1.25 & THF & 0.2 & $<10$ \\
\hline 11 & $\mathrm{CsOBz}-\mathrm{F}^{[\mathrm{c}]}$ & 1.25 & THF & 0.2 & 60 \\
\hline 12 & $\mathrm{NaOBz}$ & 1.25 & THF & 0.2 & 50 \\
\hline 13 & $\mathrm{KOBz}$ & 1.25 & THF & 0.2 & 60 \\
\hline 14 & pyridine & 1.25 & THF & 0.2 & 60 \\
\hline 15 & $\mathrm{Et}_{3} \mathrm{~N}$ & 1.25 & THF & 0.2 & 60 \\
\hline 16 & DMAP & 1.25 & THF & 0.2 & $>95,75^{[\mathrm{b}]}$ \\
\hline 17 & DMAP & $0.2^{[\mathrm{d}]}$ & THF & 0.2 & $>95$ \\
\hline 18 & DMAP & $0.1^{[\mathrm{d}]}$ & THF & 0.2 & $>95$ \\
\hline 19 & DMAP & 1.25 & THF & 0.05 & 90 \\
\hline 20 & DMAP & 1.25 & THF & 0.1 & 90 \\
\hline 21 & DMAP & 1.25 & THF & 0.3 & 80 \\
\hline
\end{tabular}


[a] Reaction conditions: $0.3 \mathrm{mmol} 7 \mathbf{b}$ ( $67 \mathrm{mg}, 1$ equiv), $0.45 \mathrm{mmol}$ CBX 6 (123 mg, 1.5 equiv), $0.375 \mathrm{mmol}$ base (1.25 equiv.) in the corresponding solvent (1.5 mL) for $4 \mathrm{~h}$ at RT under $\mathrm{N}_{2}$. The NMR yield of $\mathbf{8 b}$ is given. [b] Isolated yield (\%) after two columns chromatography. [c] Cesium 4-fluorobenzoate. [d] Catalytic amount of DMAP allowed the complete conversion of the amino acid into the corresponding hydantoin, however the time of reaction is not reproducible.

A screening of the hypervalent iodine cyanating reagents was performed (Scheme S1). The structure of the reagent is important, particularly the core of the five membered ring: 1-cyano3,3-dimethyl-1,2-benziodoxole (CDBX, 6b) did not promote formation of the hydantoin, instead starting material was recovered. Substituents on the aromatic ring also have an effect on the reactivity. A weak electron donating $t$-Bu group in meta position to the iodine $(\mathbf{6 c})$ led to lower yields, as well as a strong electron withdrawing nitro group in para position to the iodine (6d). Same NMR yield as CBX (6) was observed with compound $\mathbf{6 e}$, bearing a fluorine group in para position, but a lower isolated yield was obtained. The reaction was not complete with 6f, maybe due to the insolubility of this reagent.

\section{Scheme S1. Reagents screening.}
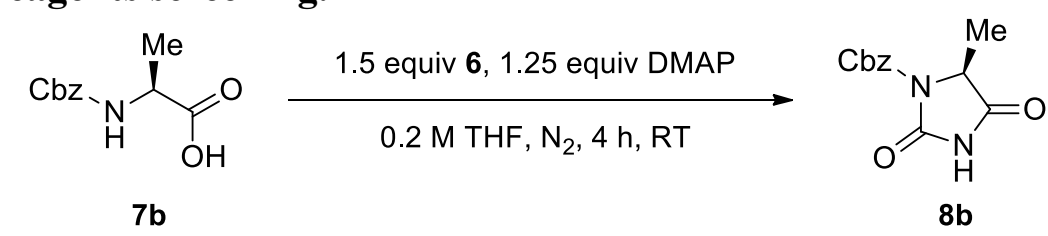<smiles>N#CI1OC(=O)c2ccccc21</smiles><smiles>CC1(C)OI(C#N)c2ccccc21</smiles><smiles>CC(C)(C)c1ccc2c(c1)I(C#N)OC2=O</smiles>

CBX (6) $>95 \%$ $75 \%$ isolated

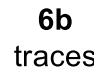
traces
$80 \%$<smiles>N#CI1OC(=O)c2cc([N+](=O)[O-])ccc21</smiles>

6d $50 \%$<smiles>N#CI1OC(=O)c2cc(F)ccc21</smiles><smiles>N#CI1OC(=O)c2cc3ccccc3cc21</smiles>
$50 \%$ isolated

$6 f$
$75 \%$ 


\section{General procedure for hydantoin synthesis:}<smiles>[R]NC([R])C(=O)O</smiles>

7

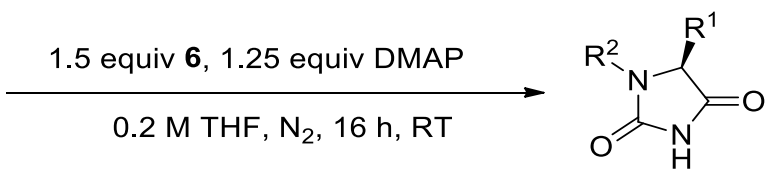

8

Dry THF $(0.75 \mathrm{~mL})$ was added in a flame dried $1 \mathrm{~mL}$ test tube containing a teflon coated stirring bar, the commercially available amino acid 7 (0.15 mmol, 1.0 equiv), CBX reagent (6) (61 mg, 0.23 mmol, 1.5 equiv) and DMAP (23.0 mg, $0.188 \mathrm{mmol}, 1.25$ equiv) under $\mathrm{N}_{2}$ (vaccum / $\mathrm{N}_{2}$ exchange). The resulting mixture was stirred for $16 \mathrm{~h}$ at room temperature. After completion of the reaction, the reaction mixture was concentrated under reduced pressure. Purification was performed by preparative TLC (Heptane/ $\mathrm{Et}_{2} \mathrm{O}$ ) affording the corresponding hydantoin 8 .

\section{(S)-tert-Butyl 5-methyl-2,4-dioxoimidazolidine-1-carboxylate (8a)}

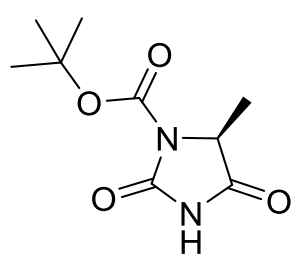

Starting from 7a $(28 \mathrm{mg}, 0.15 \mathrm{mmol})$, the crude product was purified by preparative TLC (Heptane/Et $\left.{ }_{2} \mathrm{O}=25: 75\right)$ to afford 8a as colorless sticky solid (27 mg, $\left.0.13 \mathrm{mmol}, 85 \%\right)$. Rf: $0.38($ Heptane/Et $2 \mathrm{O}=25: 75) .{ }^{1} \mathrm{H}$ NMR $\left(400 \mathrm{MHz}, \mathrm{CDCl}_{3}\right) \delta 8.02(\mathrm{~s}, 1 \mathrm{H}, \mathrm{NH}), 4.43(\mathrm{q}, J=6.9$ $\left.\mathrm{Hz}, 1 \mathrm{H}, \mathrm{NCHCH}_{3}\right), 1.60\left(\mathrm{~d}, J=6.9 \mathrm{~Hz}, 3 \mathrm{H}, \mathrm{CH}_{3}\right), 1.56\left(\mathrm{~s}, 9 \mathrm{H}, \mathrm{OC}\left(\mathrm{CH}_{3}\right)_{3}\right) .{ }^{13} \mathrm{C} \mathrm{NMR}(101$ $\left.\mathrm{MHz}, \mathrm{CDCl}_{3}\right) \delta 171.6,151.4,148.4,84.7,57.3,28.2,17.0 . \mathrm{IR}\left(v_{\max }, \mathrm{cm}^{-1}\right) 3666(\mathrm{~m}), 2988(\mathrm{~s})$, 2969 (s), 2901 (s), 2256 (w), 1936 (w), 1809 (w), 1761 (w), 1722 (w), 1477 (w), 1450 (w), 1404 (m), 1377 (m), 1347 (w), 1317 (w), 1251 (m), 1228 (m), 1196 (w), 1160 (w), 1073 (s), 1054 (s), $908(\mathrm{~m}), 874(\mathrm{w}), 826(\mathrm{w}), 803(\mathrm{w}), 780(\mathrm{w}), 737$ (m). HRMS (ESI) calcd for $\mathrm{C}_{9} \mathrm{H}_{14} \mathrm{~N}_{2} \mathrm{NaO}_{4}{ }^{+}$ $[\mathrm{M}+\mathrm{Na}]^{+} 237.0846$; found 237.0852. $[\alpha]_{\mathrm{D}}^{20}=+34.7\left(\mathrm{c}=0.29, \mathrm{CHCl}_{3}\right)$.

\section{(S)-Benzyl 5-methyl-2,4-dioxoimidazolidine-1-carboxylate (8b)}<smiles>CC1C(=O)NC(=O)N1C(=O)OCc1ccccc1</smiles>

Starting from $7 \mathbf{b}(33 \mathrm{mg}, 0.15 \mathrm{mmol})$, the crude product was purified by preparative TLC (Heptane $/ \mathrm{Et}_{2} \mathrm{O}=25: 75$ ) to afford $\mathbf{8 b}$ as white solid (33 mg, $0.13 \mathrm{mmol}, 85 \%$ ). Rf: 0.40 
(Heptane/Et $2 \mathrm{O}=25: 75)$. M. p. $117{ }^{\circ} \mathrm{C} .{ }^{1} \mathrm{H}$ NMR $\left(400 \mathrm{MHz}, \mathrm{CDCl}_{3}\right) \delta 8.01(\mathrm{~s}, 1 \mathrm{H}, \mathrm{NH}), 7.46-$ $7.34(\mathrm{~m}, 5 \mathrm{H}, \mathrm{ArH}), 5.33\left(\mathrm{dd}, J=11.9 \mathrm{~Hz}, 2 \mathrm{H}, \mathrm{CH}_{2} \mathrm{Ar}\right), 4.50$ (q, $\left.J=6.9 \mathrm{~Hz}, 1 \mathrm{H}, \mathrm{NCHCH}_{3}\right), 1.60$ $\left(\mathrm{d}, J=6.9 \mathrm{~Hz}, 3 \mathrm{H}, \mathrm{CH}_{3}\right) .{ }^{13} \mathrm{C} \mathrm{NMR}\left(101 \mathrm{MHz}, \mathrm{CDCl}_{3}\right) \delta 171.2,150.6,149.6,134.4,128.6$, 128.6, 128.2, 68.8, 57.1, 16.5. IR (vmax, $\left.\mathrm{cm}^{-1}\right) 3248$ (w), 2751 (w), 2255 (w), $1816(\mathrm{~m}), 1755$ (s), $1626(\mathrm{w}), 1499$ (w), 1453 (w), 1385 (s), 1340 (s), 1306 (s), 1268 (m), 1211 (m), 1189 (m), 1105 (m), 1062 (w), 1002 (m), 943 (w), 913 (m), 845 (w), 776 (m), 740 (m). HRMS (ESI) calcd for $\mathrm{C}_{12} \mathrm{H}_{12} \mathrm{~N}_{2} \mathrm{NaO}_{4}{ }^{+}[\mathrm{M}+\mathrm{Na}]^{+} 271.0689$; found 271.0693. $[\alpha]_{D}{ }^{20}=+21.3\left(\mathrm{c}=1.00, \mathrm{CHCl}_{3}\right)$. Chiral HPLC conditions: ee $=96 \%$; Chiralpak ID 85:15 Hexane/iPrOH, $1.0 \mathrm{~mL} / \mathrm{min}, 60 \mathrm{~min}$. $\operatorname{tr}=27.3 \mathrm{~min}, \lambda=210 \mathrm{~cm}^{-1}$.

(S)-(9H-Fluoren-9-yl)methyl 5-methyl-2,4-dioxoimidazolidine-1-carboxylate (8c)

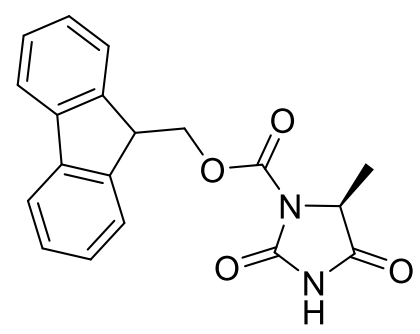

Starting from 7c $(46.7 \mathrm{mg}, 0.150 \mathrm{mmol})$, the crude product was purified by preparative TLC (Heptane/Et $2 \mathrm{O}=25: 75)$ to afford 8c as white sticky solid (27 mg, $80 \mu \mathrm{mol}, 54 \%$ ). Rf: 0.35 (Heptane/Et $\left.{ }_{2} \mathrm{O}=25: 75\right) .{ }^{1} \mathrm{H}$ NMR $\left(400 \mathrm{MHz}, \mathrm{CDCl}_{3}\right) \delta 8.49(\mathrm{~s}, 1 \mathrm{H}, \mathrm{NH}), 7.78(\mathrm{~d}, J=7.5 \mathrm{~Hz}$, 2H, ArH), 7.69 (dd, $J=7.5,1.3 \mathrm{~Hz}, 2 \mathrm{H}, \operatorname{Ar} H), 7.42(\mathrm{t}, J=7.4 \mathrm{~Hz}, 2 \mathrm{H}, \operatorname{Ar} H), 7.34$ (t, $J=7.5$ $\mathrm{Hz}, 2 \mathrm{H}, \mathrm{ArH}$ ), $4.72-4.57$ (m, 2H, $\mathrm{CH}_{2} \mathrm{Ar}$ ), 4.35 - 4.23 (m, 2H, $\mathrm{NCHCH}_{3}, \mathrm{CH}$ Fmoc), 1.38 (d, $\left.J=6.9 \mathrm{~Hz}, 3 \mathrm{H}, \mathrm{CH}_{3}\right) .{ }^{13} \mathrm{C} \mathrm{NMR}\left(101 \mathrm{MHz}, \mathrm{CDCl}_{3}\right) \delta 171.7,151.2,150.0,143.2,141.5,128.2$, 127.5, 125.1, 120.2, 69.1, 57.4, 46.7, 16.4. IR ( $\left.v_{\max }, \mathrm{cm}^{-1}\right) 3666(\mathrm{~m}), 2988(\mathrm{~s}), 2902$ (s), 2255 (w), 1934 (w), 1760 (w), 1719 (w), 1475 (w), 1450 (w), 1404 (m), 1388 (m), 1345 (w), 1313 (w), $1256(\mathrm{~m}), 1230(\mathrm{~m}), 1071$ (s), 1050 (s), 909 (m), 872 (w), 733 (s). HRMS (ESI) calcd for $\mathrm{C}_{19} \mathrm{H}_{16} \mathrm{~N}_{2} \mathrm{NaO}_{4}{ }^{+}[\mathrm{M}+\mathrm{Na}]^{+}$359.1002; found 359.1000. $[\alpha]_{\mathrm{D}}{ }^{20}=+18.3\left(\mathrm{c}=1.00, \mathrm{CHCl}_{3}\right)$.

(S)-1-Acetyl-5-isopropylimidazolidine-2,4-dione (8d)<smiles>CC(=O)N1C(=O)NC(=O)C1C</smiles> 
Starting from 7d (20 mg, $0.15 \mathrm{mmol}), 30 \%$ NMR yield could be observed for acetyl protected hydantoin $\mathbf{8 d}$. The crude product could not be purified.

\section{(S)-1-benzyl-5-methylimidazolidine-2,4-dione (8e)}

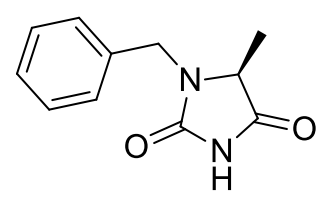

Starting from 7e (27 mg, $0.15 \mathrm{mmol}), 30 \%$ NMR yield could be observed for benzyl protected hydantoin 8e. The crude product could not be purified.

\section{(S)-Benzyl 5-isopropyl-2,4-dioxoimidazolidine-1-carboxylate (8g)}

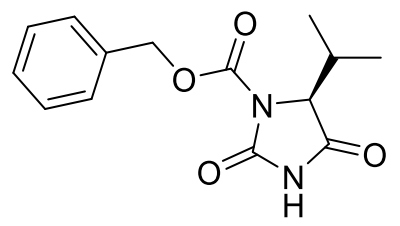

Starting from $7 \mathbf{g}(37.7 \mathrm{mg}, 0.150 \mathrm{mmol})$, the crude product was purified by preparative TLC (Heptane/Et $\left.{ }_{2} \mathrm{O}=25: 75\right)$ to afford $\mathbf{8 g}$ as colorless sticky solid (31 mg, $0.11 \mathrm{mmol}, 75 \%$ ). Rf: $0.50($ Heptane/Et $2 \mathrm{O}=25: 75) .{ }^{1} \mathrm{H}$ NMR $\left(400 \mathrm{MHz}, \mathrm{CDCl}_{3}\right) \delta 8.56(\mathrm{~s}, 1 \mathrm{H}, \mathrm{NH}), 7.46-7.32(\mathrm{~m}$, 5H, $\mathrm{ArH}$ ), $5.39-5.25$ (m, 2H, $\left.\mathrm{CH}_{2} \mathrm{Ar}\right), 4.39$ (d, $\left.J=3.4 \mathrm{~Hz}, 1 \mathrm{H}, \mathrm{NCHCH}\left(\mathrm{CH}_{3}\right)_{2}\right), 2.49$ (ddh, $J$ $\left.=10.9,7.0,3.4 \mathrm{~Hz}, 1 \mathrm{H}, \mathrm{NCHCH}\left(\mathrm{CH}_{3}\right)_{2}\right), 1.17\left(\mathrm{~d}, J=7.0 \mathrm{~Hz}, 3 \mathrm{H}, \mathrm{CH}_{3}\right), 0.91(\mathrm{~d}, J=6.9 \mathrm{~Hz}$, $\left.3 \mathrm{H}, \mathrm{CH}_{3}\right) .{ }^{13} \mathrm{C} \mathrm{NMR}\left(101 \mathrm{MHz}, \mathrm{CDCl}_{3}\right) \delta 169.9,151.5,149.8,134.5,128.5,128.4,128.0,68.7$, 65.4, 29.5, 17.7, 15.4. IR ( $\left.v_{\max }, \mathrm{cm}^{-1}\right) 3671$ (m), 2983 (s), 2972 (s), 2901 (s), 2256 (w), 1927 (w), 1795 (w), 1745 (w), 1450 (w), 1388 (m), 1310 (w), 1249 (m), 1228 (m), 1070 (s), 1052 (s), 908 (s), 872 (w), 735 (s). HRMS (ESI) calcd for $\mathrm{C}_{14} \mathrm{H}_{16} \mathrm{~N}_{2} \mathrm{NaO}_{4}{ }^{+}[\mathrm{M}+\mathrm{Na}]^{+}$299.1002; found 299.1007. $[\alpha]_{\mathrm{D}}^{20}=+26.5\left(\mathrm{c}=1.00, \mathrm{CHCl}_{3}\right)$.

(S)-Benzyl 5-isobutyl-2,4-dioxoimidazolidine-1-carboxylate (8h)<smiles>CC(C)CC1C(=O)NC(=O)N1C(=O)OCc1ccccc1</smiles>

Starting from $7 \mathbf{h}(40 \mathrm{mg}, 0.15 \mathrm{mmol})$, the crude product was purified by preparative TLC (Heptane/Et $\left.{ }_{2} \mathrm{O}=25: 75\right)$ to afford $\mathbf{8 h}$ as colorless sticky solid (24 mg, $83 \mu \mathrm{mol}, 55 \%$ ). Rf: 0.45 (Heptane $\left./ \mathrm{Et}_{2} \mathrm{O}=25: 75\right) .{ }^{1} \mathrm{H}$ NMR (400 MHz, $\left.\mathrm{CDCl}_{3}\right) \delta 8.57(\mathrm{~s}, 1 \mathrm{H}, \mathrm{NH}), 7.50-7.31(\mathrm{~m}, 5 \mathrm{H}$, $\mathrm{Ar} H$ ), $5.42-5.21\left(\mathrm{~m}, 2 \mathrm{H}, \mathrm{CH}_{2} \mathrm{Ar}\right), 4.47$ (dd, $\left.J=7.3,3.8 \mathrm{~Hz}, 1 \mathrm{H}, \mathrm{NCHCH}_{2}\right), 1.95-1.76(\mathrm{~m}$, 
$\left.3 \mathrm{H}, \mathrm{CH}_{2} \mathrm{CH}\left(\mathrm{CH}_{3}\right)_{2}\right), 0.88\left(\mathrm{dd}, \mathrm{J}=8.9,5.9 \mathrm{~Hz}, 3 \mathrm{H}, \mathrm{CH}_{3}\right), 0.87\left(\mathrm{~d}, \mathrm{~J}=9 \mathrm{~Hz}, 3 \mathrm{H}, \mathrm{CH}_{3}\right) . .{ }^{13} \mathrm{C} \mathrm{NMR}$ $\left(101 \mathrm{MHz}, \mathrm{CDCl}_{3}\right) \delta 171.6,151.6,149.9,134.7,128.9,128.8,128.6,69.0,59.9,39.2,24.1$, 23.4, 22.1. IR ( $\left.v_{\max }, \mathrm{cm}^{-1}\right) 3257(\mathrm{w}), 2962(\mathrm{w}), 2254(\mathrm{w}), 1815(\mathrm{~m}), 1745(\mathrm{~m}), 1498(\mathrm{w}), 1463$ (w), 1386 (m), 1333 (w), 1304 (m), 1269 (w), 1210 (w), 1112 (w), 1029 (w), 910 (s), 776 (w), 735 (s). HRMS (ESI) calcd for $\mathrm{C}_{15} \mathrm{H}_{18} \mathrm{~N}_{2} \mathrm{NaO}_{4}{ }^{+}[\mathrm{M}+\mathrm{Na}]^{+} 313.1159$; found 313.1160. $[\alpha]_{\mathrm{D}}{ }^{20}=$ $+39.3\left(\mathrm{c}=1.00, \mathrm{CHCl}_{3}\right)$.

(2S,3S)-2-(((Benzyloxy)carbonyl)amino)-3-methylpentanoic acid (8i)

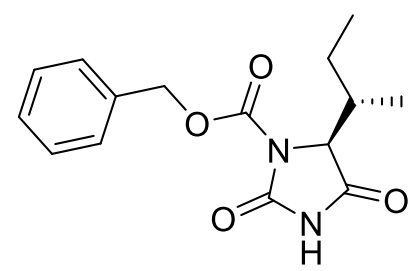

Starting from $7 \mathbf{i}(39.8 \mathrm{mg}, 0.150 \mathrm{mmol})$, the crude product was purified by preparative TLC (Heptane $/ \mathrm{Et}_{2} \mathrm{O}=20: 80$ ) to afford $\mathbf{8 i}$ as colorless sticky solid (34.7 mg, $0.120 \mathrm{mmol}, 80 \%$ ). Rf: $0.60($ Heptane/Et $2 \mathrm{O}=20: 80) .{ }^{1} \mathrm{H}$ NMR $\left(400 \mathrm{MHz}, \mathrm{CDCl}_{3}\right) \delta 7.47-7.31$ (m, 5H, $\left.\mathrm{ArH}\right), 5.41-$ $5.25\left(\mathrm{~m}, 2 \mathrm{H}, \mathrm{CH}_{2} \mathrm{Ar}\right), 4.50(\mathrm{dd}, J=3.3,2.2 \mathrm{~Hz}, 1 \mathrm{H}, \mathrm{NCHCH}), 2.30-2.15(\mathrm{~m}, 1 \mathrm{H}$, $\left.\mathrm{CHCH}\left(\mathrm{CH}_{3}\right) \mathrm{CH}_{2} \mathrm{CH}_{3}\right), 1.68\left(\mathrm{dp}, J=14.4,7.3 \mathrm{~Hz}, 1 \mathrm{H}, \mathrm{CHCH}\left(\mathrm{CH}_{3}\right) \mathrm{CH}_{2} \mathrm{CH}_{3}\right), 1.54(\mathrm{dq}, J=$ 14.3, $\left.7.5 \mathrm{~Hz}, 1 \mathrm{H}, \mathrm{CHCH}\left(\mathrm{CH}_{3}\right) \mathrm{CH}_{2} \mathrm{CH}_{3}\right), 0.95\left(\mathrm{t}, J=7.4 \mathrm{~Hz}, 3 \mathrm{H}, \mathrm{CHCH}\left(\mathrm{CH}_{3}\right) \mathrm{CH}_{2} \mathrm{CH}_{3}\right), 0.89$ $\left(\mathrm{dd}, J=7.0,1.3 \mathrm{~Hz}, 3 \mathrm{H}, \mathrm{CHCH}\left(\mathrm{CH}_{3}\right) \mathrm{CH}_{2} \mathrm{CH}_{3}\right) .{ }^{13} \mathrm{C} \mathrm{NMR}\left(101 \mathrm{MHz}, \mathrm{CDCl}_{3}\right) \delta 169.9,151.6$, 150.0, 134.7, 128.9, 128.9, 128.4, 69.1, 64.4, 36.4, 25.3, 13.1, 12.0. HRMS (ESI) calcd for $\mathrm{C}_{15} \mathrm{H}_{19} \mathrm{~N}_{2} \mathrm{O}_{4}{ }^{+}[\mathrm{M}+\mathrm{H}]^{+}$291.1339; found 291.1340. IR ( $\left.v_{\max }, \mathrm{cm}^{-1}\right) 3668(\mathrm{w}), 3251(\mathrm{w}), 2979(\mathrm{w})$, 2915 (w), 1802 (w), 1745 (w), 1479 (w), 1467 (w), 1391 (w), 1309 (w), 1245 (w), 1150 (w), $1100(\mathrm{w}), 1068(\mathrm{w}), 910(\mathrm{~s}), 840(\mathrm{w}), 771(\mathrm{w}), 746(\mathrm{~s}), 657(\mathrm{w}) \cdot[\alpha]_{\mathrm{D}}^{20}=+28.7(\mathrm{c}=1.00$, $\left.\mathrm{CHCl}_{3}\right)$.

(S)-Benzyl 5-benzyl-2,4-dioxoimidazolidine-1-carboxylate (8j)

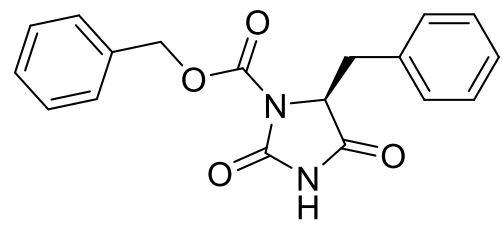

Starting from $7 \mathbf{j}$ (45 $\mathrm{mg}, 0.15 \mathrm{mmol}$ ), the crude product was purified by preparative TLC (Heptane/Et $2 \mathrm{O}=25: 75$ ) to afford $\mathbf{8 j}$ as yellowish sticky solid (41 mg, $0.13 \mathrm{mmol}, 85 \%$ ). Rf: $0.52\left(\right.$ Heptane/Et $\left._{2} \mathrm{O}=25: 75\right) .{ }^{1} \mathrm{H}$ NMR $\left(400 \mathrm{MHz}, \mathrm{CDCl}_{3}\right) \delta 7.61(\mathrm{~s}, 1 \mathrm{H}, \mathrm{NH}), 7.50-7.46(\mathrm{~m}$, 2H, ArH), $7.45-7.38$ (m, 3H, ArH), $7.22-7.15$ (m, 3H, ArH), $6.95-6.85$ (m, 2H, ArH), 5.38 (s, 2H, $\mathrm{CH}_{2} \mathrm{Ar}$ ), 4.73 (dd, $J=5.6,2.6 \mathrm{~Hz}, 1 \mathrm{H}, \mathrm{NCHCH}_{2} \mathrm{Ar}$ ), 3.44 (dd, $J=14.1,5.6 \mathrm{~Hz}, 1 \mathrm{H}$, 
$\left.\mathrm{NCHCH}_{2} \mathrm{Ar}\right), 3.26\left(\mathrm{dd}, J=14.1,2.7 \mathrm{~Hz}, 1 \mathrm{H}, \mathrm{NCHCH}_{2} \mathrm{Ar}\right) .{ }^{13} \mathrm{C} \mathrm{NMR}\left(101 \mathrm{MHz}, \mathrm{CDCl}_{3}\right) \delta$ $169.9,150.6,150.1,134.8,133.0,129.7,129.0,128.9,128.9,128.8,127.8,69.1,61.9,35.0$. IR $\left(v_{\max }, \mathrm{cm}^{-1}\right) 3669(\mathrm{~m}), 2983$ (s), 2901 (s), 2256 (w), 1936 (w), 1815 (w), 1751 (w), 1479 (w), 1447 (w), 1388 (m), 1310 (w), 1253 (m), 1230 (m), 1070 (s), 908 (m), 869 (w), 735 (m). HRMS (ESI) calcd for $\mathrm{C}_{18} \mathrm{H}_{16} \mathrm{~N}_{2} \mathrm{NaO}_{4}{ }^{+}[\mathrm{M}+\mathrm{Na}]^{+} 347.1002$; found 347.1006. $[\alpha]_{\mathrm{D}}{ }^{20}=+91.5(\mathrm{c}=1.00$, $\left.\mathrm{CHCl}_{3}\right)$.

(S)-2-((tert-Butoxycarbonyl)amino)-3-(4-((2,6-dichlorobenzyl)oxy)phenyl)propanoic acid $(\mathbf{8 k})$

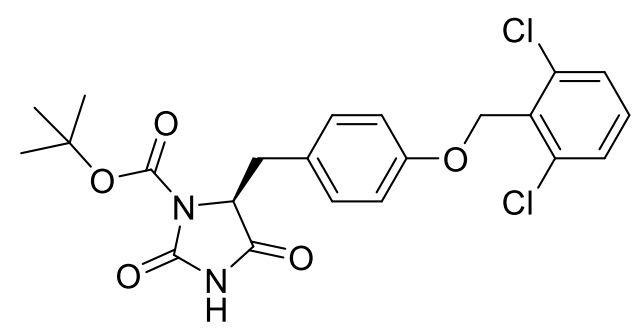

Starting from 7k $(66 \mathrm{mg}, 0.15 \mathrm{mmol})$, the crude product was purified by preparative TLC (Heptane $/ \mathrm{Et}_{2} \mathrm{O}=20: 80$ ) to afford $\mathbf{8 k}$ as white solid (63.0 mg, $0.135 \mathrm{mmol}, 90 \%$ ). Rf: 0.58 (Heptane/Et $\left.{ }_{2} \mathrm{O}=20: 80\right) .{ }^{1} \mathrm{H}$ NMR (400 MHz, $\left.\mathrm{CDCl}_{3}\right) \delta 7.39-7.33(\mathrm{~m}, 2 \mathrm{H}, \mathrm{ArH}), 7.25-7.21$ (m, 1H, ArH), $7.08-7.00$ (m, 2H, ArH), $6.97-6.89$ (m, 2H, ArH), 5.23 (d, J=0.8 Hz, 2H, $\mathrm{ArOCH}_{2} \mathrm{Ar}$ ), $4.67\left(\mathrm{dd}, J=5.5,2.7 \mathrm{~Hz}, 1 \mathrm{H}, \mathrm{NCHCH}_{2}\right), 3.44(\mathrm{dd}, J=14.2,5.5 \mathrm{~Hz}, 1 \mathrm{H}$, $\left.\mathrm{NCHCH}_{2}\right), 3.25\left(\mathrm{dd}, J=14.2,2.7 \mathrm{~Hz}, 1 \mathrm{H}, \mathrm{NCHCH}_{2}\right), 1.62\left(\mathrm{~s}, 9 \mathrm{H}, \mathrm{O}\left(\mathrm{CH}_{3}\right)_{3}\right) .{ }^{13} \mathrm{C} \mathrm{NMR}(101$ $\left.\mathrm{MHz}, \mathrm{CDCl}_{3}\right) \delta 170.0,158.5,150.8,148.6,137.2,132.2,130.9,130.6,128.6,125.9,115.4$, 84.8, 65.3, 62.1, 34.5, 28.2. HRMS (ESI) calcd for $\mathrm{C}_{22} \mathrm{H}_{22} \mathrm{Cl}_{2} \mathrm{~N}_{2} \mathrm{NaO}_{5}{ }^{+}[\mathrm{M}+\mathrm{Na}]^{+}$487.0798; found 487.0800. IR $\left(v_{\max }, \mathrm{cm}^{-1}\right) 3668(\mathrm{w}), 3251(\mathrm{w}), 2985(\mathrm{w}), 2878(\mathrm{w}), 1821(\mathrm{w}), 1745(\mathrm{w})$, 1606 (w), $1511(\mathrm{w}), 1378$ (w), 1321 (w), 1245 (w), 1163 (w), 1081 (w), $1011(\mathrm{w}), 910$ (s), 840 $(\mathrm{w}), 746(\mathrm{~s}), 657(\mathrm{w}) \cdot[\alpha]_{\mathrm{D}}^{20}=+67.0\left(\mathrm{c}=1.00, \mathrm{CHCl}_{3}\right)$.

(S)-Benzyl 5-((1H-indol-3-yl)methyl)-2,4-dioxoimidazolidine-1-carboxylate (81)

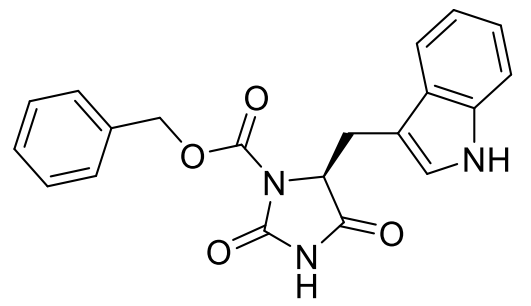

Starting from 71 (50.8 $\mathrm{mg}, 0.150 \mathrm{mmol})$, the crude product was purified by preparative TLC (Heptane/Et $2 \mathrm{O}=25: 75$ ) to afford $\mathbf{8 1}$ as yellow sticky solid (36 mg, $99 \mu \mathrm{mol}, 66 \%$ ). Rf: 0.30 
(Heptane/Et $\left.{ }_{2} \mathrm{O}=25: 75\right) .{ }^{1} \mathrm{H}$ NMR (400 MHz, $\left.\mathrm{CDCl}_{3}\right) \delta 8.07$ (s, $\left.1 \mathrm{H}, \mathrm{NH}\right), 7.76(\mathrm{~s}, 1 \mathrm{H}, \mathrm{NH})$, $7.51-7.39$ (m, 6H, ArH), 7.28 (s, 1H, ArH), $7.19-7.09$ (m, 1H, ArH), 7.01 (ddd, J = 8.0, 7.0, $1.1 \mathrm{~Hz}, 1 \mathrm{H}, \mathrm{ArH}), 6.71(\mathrm{~d}, J=2.4 \mathrm{~Hz}, 1 \mathrm{H}, \mathrm{ArH}), 5.45-5.33$ (m, 2H, CH $\left.\mathrm{C}_{2} \mathrm{Ar}\right), 4.73$ (dd, J = 5.4, $2.6 \mathrm{~Hz}, 1 \mathrm{H}, \mathrm{NCHCH}_{2} \mathrm{Ar}$ ), 3.61 (dd, $J=15.0,5.4 \mathrm{~Hz}, 1 \mathrm{H}, \mathrm{NCHCH}_{2} \mathrm{Ar}$ ), 3.49 (dd, $J=15.0,2.6$ $\left.\mathrm{Hz}, 1 \mathrm{H}, \mathrm{NCHCH}_{2} \mathrm{Ar}\right) .{ }^{13} \mathrm{C} \mathrm{NMR}\left(101 \mathrm{MHz}, \mathrm{CDCl}_{3}\right) \delta 170.8,151.0,150.2,136.0,134.9,129.0$, 128.9, 128.9, 127.5, 124.0, 122.4, 120.1, 118.7, 111.3, 107.1, 69.1, 61.8, 25.3. HRMS (ESI) calcd for $\mathrm{C}_{20} \mathrm{H}_{17} \mathrm{~N}_{3} \mathrm{NaO}_{4}{ }^{+}[\mathrm{M}+\mathrm{Na}]^{+}$386.1111; found 386.1105. IR ( $\left.v_{\max }, \mathrm{cm}^{-1}\right) 3669$ (m), 2983 (s), 2972 (s), 2901 (s), 2252 (w), 1932 (w), 1799 (w), 1735 (w), 1454 (w), 1402 (m), 1386 (m), $1315(\mathrm{w}), 1251(\mathrm{~m}), 1228(\mathrm{~m}), 1073(\mathrm{~s}), 1054(\mathrm{~s}), 908(\mathrm{~m}), 872(\mathrm{w}), 735(\mathrm{~m}) \cdot[\alpha]_{\mathrm{D}}{ }^{20}=+20.2$ $\left(\mathrm{c}=1.00, \mathrm{CHCl}_{3}\right)$.

(R)-2-((tert-Butoxycarbonyl)amino)-3-(1H-indol-3-yl)propanoic acid (8m)

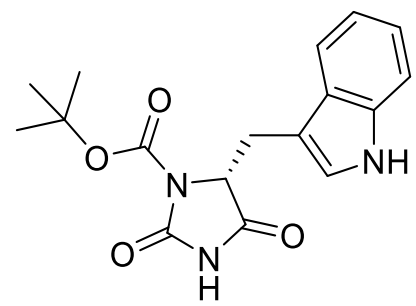

Starting from $7 \mathbf{m}(45.7 \mathrm{mg}, 0.150 \mathrm{mmol})$, the crude product was purified by preparative TLC (Heptane $\left./ \mathrm{Et}_{2} \mathrm{O}=10: 90\right)$ to afford $\mathbf{8 m}$ as greenish sticky solid (42.5 mg, $\left.0.129 \mathrm{mmol}, 86 \%\right)$. Rf: $0.63($ Heptane/Et $2 \mathrm{O}=10: 90) .{ }^{1} \mathrm{H}$ NMR $\left(400 \mathrm{MHz}, \mathrm{CDCl}_{3}\right) \delta 8.21(\mathrm{~s}, 1 \mathrm{H}, \mathrm{NH}), 7.61-7.52(\mathrm{~m}$, 1H, $\operatorname{Ar} H$ ), $7.39-7.29$ (m, 1H, ArH), 7.18 (ddd, $J=8.2,7.0,1.2 \mathrm{~Hz}, 1 \mathrm{H}, \operatorname{Ar} H), 7.10$ (ddd, $J=$ 8.1, 7.0, 1.1 Hz, 1H, ArH), $6.95(\mathrm{~d}, J=2.4 \mathrm{~Hz}, 1 \mathrm{H}, \operatorname{Ar} H), 4.70(\mathrm{dd}, J=5.3,2.7 \mathrm{~Hz}, 1 \mathrm{H}$, $\left.\mathrm{NCHCH}_{2}\right), 3.64\left(\mathrm{dd}, J=15.0,5.2 \mathrm{~Hz}, 1 \mathrm{H}, \mathrm{NCHCH}_{2}\right), 3.51\left(\mathrm{dd}, J=14.9,2.7 \mathrm{~Hz}, 1 \mathrm{H}, \mathrm{NCHCH}_{2}\right)$, 1.63 (s, 9H, $\left.\mathrm{O}\left(\mathrm{CH}_{3}\right)_{3}\right) .{ }^{13} \mathrm{C} \mathrm{NMR}\left(101 \mathrm{MHz}, \mathrm{CDCl}_{3}\right) \delta 170.9,151.3,148.8,136.0,127.7,123.8$, 122.4, 120.0, 118.9, 111.3, 107.4, 84.7, 61.8, 28.2, 25.4. HRMS (ESI) calcd for $\mathrm{C}_{17} \mathrm{H}_{19} \mathrm{~N}_{3} \mathrm{NaO}_{4}{ }^{+}$ $[\mathrm{M}+\mathrm{Na}]^{+}$352.1268; found 352.1262. IR $\left(v_{\max }, \mathrm{cm}^{-1}\right) 2979(\mathrm{w}), 2896(\mathrm{w}), 1827(\mathrm{w}), 1751(\mathrm{w})$, $1372(w), 1321(w), 1226(w), 1163$ (w), 1068 (w), $1011(w), 914$ (s), $841(w), 747$ (s), 644 (w). $[\alpha]_{\mathrm{D}}^{20}=-55.0\left(\mathrm{c}=1.00, \mathrm{CHCl}_{3}\right)$.

Benzyl (R)-5-((benzylthio)methyl)-2,4-dioxoimidazolidine-1-carboxylate (8n)<smiles>O=C1NC(=O)N(C(=O)OCc2ccccc2)C1CSCc1ccccc1</smiles> 
Starting from $7 \mathrm{n}(52 \mathrm{mg}, 0.15 \mathrm{mmol})$, the crude product was purified by preparative TLC (Heptane/Et $2 \mathrm{O}=25: 75$ ) to afford $\mathbf{8 n}$ as yellowish sticky solid (31 mg, $83 \mu \mathrm{mol}, 55 \%$ ). Rf: 0.45 (Heptane/Et $2 \mathrm{O}=25: 75) .{ }^{1} \mathrm{H}$ NMR (400 MHz, $\left.\mathrm{CDCl}_{3}\right) \delta 8.61(\mathrm{~s}, 1 \mathrm{H}, \mathrm{NH}), 7.48-7.21(\mathrm{~m}, 10 \mathrm{H}$, $\mathrm{ArH}$ ), 5.31 (s, 2H, $\left.\mathrm{CH}_{2} \mathrm{Ar}\right), 4.69$ (dd, $\left.J=4.5,2.3 \mathrm{~Hz}, 1 \mathrm{H}, \mathrm{NCHCH}_{2}\right), 3.72-3.53(\mathrm{~m}, 2 \mathrm{H}$, $\left.\mathrm{SCH}_{2} \mathrm{Ar}\right), 3.25\left(\mathrm{dd}, J=14.6,4.5 \mathrm{~Hz}, 1 \mathrm{H}, \mathrm{NCHCH}_{2}\right), 3.06\left(\mathrm{dd}, J=14.7,2.4 \mathrm{~Hz}, 1 \mathrm{H}, \mathrm{NCHCH}_{2}\right)$. ${ }^{13} \mathrm{C}$ NMR $\left(101 \mathrm{MHz}, \mathrm{CDCl}_{3}\right) \delta 169.9,151.5,149.9,137.4,134.6,129.1,128.9,128.9,128.7$, 128.5, 127.5, 69.2, 61.4, 37.5, 30.7. IR ( $\left.v_{\max }, \mathrm{cm}^{-1}\right) 3669$ (m), 2988 (s), 2908 (m), $2259(\mathrm{w})$, 1824 (w), 1754 (w), 1450 (w), 1409 (m), 1390 (m), 1310 (w), 1253 (m), 1228 (m), 1070 (s), 910 (s), 867 (w), 735 (s). HRMS (ESI) calcd for $\mathrm{C}_{19} \mathrm{H}_{18} \mathrm{~N}_{2} \mathrm{NaO}_{4} \mathrm{~S}^{+}[\mathrm{M}+\mathrm{Na}]^{+}$393.0879; found 393.0885. $[\alpha]_{\mathrm{D}}^{20}=+10.2\left(\mathrm{c}=1.00, \mathrm{CHCl}_{3}\right)$.

\section{(S)-Benzyl 5-(2-(methylthio)ethyl)-2,4-dioxoimidazolidine-1-carboxylate (8o)}

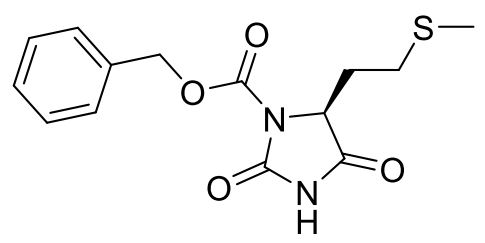

Starting from 7o $(43 \mathrm{mg}, 0.15 \mathrm{mmol})$, the crude product was purified by preparative TLC (Heptane/Et $2 \mathrm{O}=10: 90)$ to afford 80 as white sticky solid (31 mg, $0.10 \mathrm{mmol}, 67 \%$ ). Rf: 0.46 (Heptane/Et $\left.{ }_{2} \mathrm{O}=10: 90\right) .{ }^{1} \mathrm{H}$ NMR $\left(400 \mathrm{MHz}, \mathrm{CDCl}_{3}\right) \delta 8.33(\mathrm{~s}, 1 \mathrm{H}, \mathrm{NH}), 7.42-7.23(\mathrm{~m}, 5 \mathrm{H}$, $\mathrm{ArH}), 5.36-5.13\left(\mathrm{~m}, 2 \mathrm{H}, \mathrm{CH}_{2} \mathrm{Ar}\right), 4.54$ (dd, $\left.J=6.3,3.8 \mathrm{~Hz}, 1 \mathrm{H}, \mathrm{NCHCH}_{2}\right), 2.59-2.37$ (m, $\left.2 \mathrm{H}, \mathrm{CH}_{2} \mathrm{CH}_{2} \mathrm{~S}\right), 2.33-2.20\left(\mathrm{~m}, 2 \mathrm{H}, \mathrm{CH}_{2} \mathrm{CH}_{2} \mathrm{~S}\right), 1.94\left(\mathrm{~s}, 3 \mathrm{H}, \mathrm{SCH}_{3}\right) .{ }^{13} \mathrm{C} \mathrm{NMR}(101 \mathrm{MHz}$, $\left.\mathrm{CDCl}_{3}\right) \delta 170.8,151.4,150.0,134.6,128.9,128.9,128.6,69.2,59.9,28.7,28.4,15.3$. HRMS (ESI) calcd for $\mathrm{C}_{14} \mathrm{H}_{16} \mathrm{~N}_{2} \mathrm{NaO}_{4} \mathrm{~S}^{+}[\mathrm{M}+\mathrm{Na}]^{+} 331.0723$; found 331.0730. IR $\left(v_{\max }, \mathrm{cm}^{-1}\right) 3225(\mathrm{w})$, 2979 (w), 2909 (w), 1821 (w), 1745 (m), 1498 (w), 1460 (w), 1378 (m), 1353 (w), 1302 (m), 1264 (w), 1195 (w), 1150 (w), 1106 (w), 1075 (w), 916 (s), 859 (w), 746 (s), 695 (w), 657 (w). $[\alpha]_{\mathrm{D}}^{20}=+44.5\left(\mathrm{c}=1.00, \mathrm{CHCl}_{3}\right)$.

\section{2-(((Benzyloxy)carbonyl)amino)-6-((tert-butoxycarbonyl)amino)hexanoic acid (8p)}

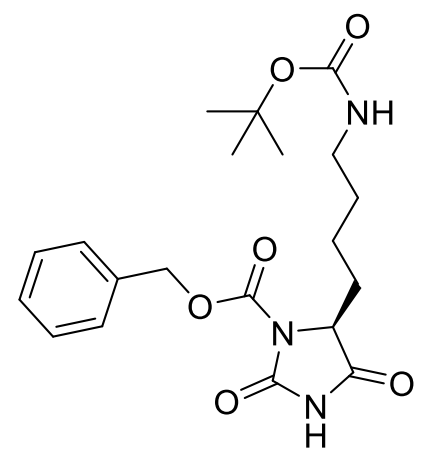


Starting from 7p $(57 \mathrm{mg}, 0.15 \mathrm{mmol})$, the crude product was purified by preparative TLC (Heptane/Et $\left.{ }_{2} \mathrm{O}=10: 90\right)$ to afford $\mathbf{8 p}$ as colorless sticky solid (50 mg, $\left.0.12 \mathrm{mmol}, 82 \%\right)$. Rf: $0.58($ Heptane/Et $2 \mathrm{O}=10: 90) .{ }^{1} \mathrm{H}$ NMR $\left(400 \mathrm{MHz}, \mathrm{CDCl}_{3}\right) \delta 8.86(\mathrm{~s}, 1 \mathrm{H}, \mathrm{NH}), 7.46-7.31(\mathrm{~m}$, $5 \mathrm{H}, \mathrm{ArH}), 5.41-5.24\left(\mathrm{~m}, 2 \mathrm{H}, \mathrm{CH}_{2} \mathrm{Ar}\right), 4.55$ (s, $\left.1 \mathrm{H}, \mathrm{NH}\right), 4.49(\mathrm{dd}, J=6.2,3.2 \mathrm{~Hz}, 1 \mathrm{H}$, $\left.\mathrm{NCHCH}_{2}\right), 3.05$ (q, $\left.J=6.5 \mathrm{~Hz}, 2 \mathrm{H}, \mathrm{CH}_{2} \mathrm{NHBoc}\right), 2.15-1.90\left(\mathrm{~m}, 2 \mathrm{H}, \mathrm{NCHCH}{ }_{2}\right), 1.43(\mathrm{~m}, 13 \mathrm{H}$, $\left.\mathrm{NCHCH}_{2} \mathrm{CH}_{2} \mathrm{CH}_{2}, \mathrm{O}\left(\mathrm{CH}_{3}\right)_{3}\right) .{ }^{13} \mathrm{C} \mathrm{NMR}\left(101 \mathrm{MHz}, \mathrm{CDCl}_{3}\right) \delta 171.0,156.1,151.7,150.0,134.8$, 128.9, 128.9, 128.6, 79.5, 69.0, 61.0, 40.3, 29.7, 29.5, 28.5, 20.4. HRMS (ESI) calcd for $\mathrm{C}_{20} \mathrm{H}_{27} \mathrm{~N}_{3} \mathrm{NaO}_{6}{ }^{+}[\mathrm{M}+\mathrm{Na}]^{+}$428.1792; found 428.1795. IR ( $\left.v_{\max }, \mathrm{cm}^{-1}\right) 2985(\mathrm{w}), 2896(\mathrm{w}), 1808$ (w), 1764 (w), $1511(w), 1454(w), 1391(w), 1296(w), 1252$ (w), $1176(w), 1100(w), 1068$ (w), $980(\mathrm{w}), 910(\mathrm{~s}), 853(\mathrm{w}), 739(\mathrm{~s}), 651(\mathrm{w}) .[\alpha]_{\mathrm{D}}{ }^{20}=+34.3\left(\mathrm{c}=1.00, \mathrm{CHCl}_{3}\right)$.

\section{(S)-2-((((9H-Fluoren-9-yl)methoxy)carbonyl)amino)-5-(tert-butoxy)-5-oxopentanoic acid} $(\mathbf{8 q})$

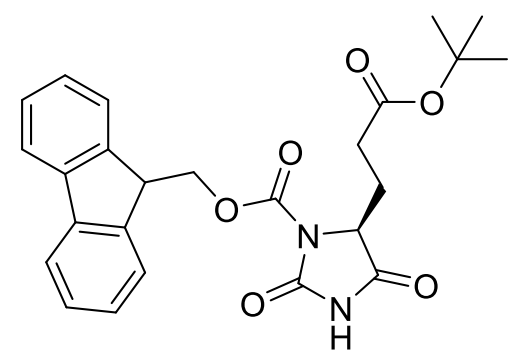

Starting from 7q $(63.8 \mathrm{mg}, 0.150 \mathrm{mmol})$, the crude product was purified by preparative TLC (Heptane/Et $2 \mathrm{O}=20: 80$ ) to afford $\mathbf{8 q}$ as colorless sticky solid (36.5 mg, $81.0 \mu \mathrm{mol}, 54 \%$ ). Rf: $0.46\left(\right.$ Heptane/Et $\left._{2} \mathrm{O}=20: 80\right) .{ }^{1} \mathrm{H}$ NMR $\left(400 \mathrm{MHz}, \mathrm{CDCl}_{3}\right) \delta 7.85(\mathrm{~s}, 1 \mathrm{H}, \mathrm{NH}), 7.81-7.68(\mathrm{~m}$, $4 \mathrm{H}, \operatorname{Ar} H), 7.46-7.30(\mathrm{~m}, 4 \mathrm{H}, \mathrm{ArH}), 4.71-4.57\left(\mathrm{~m}, 2 \mathrm{H}, \mathrm{OCH}_{2} \mathrm{CH}\right), 4.44-4.27(\mathrm{~m}, 2 \mathrm{H}$, $\left.\mathrm{NCHCH}_{2}, \mathrm{OCH}_{2} \mathrm{CH}\right), 2.37-2.06\left(\mathrm{~m}, 4 \mathrm{H}, \mathrm{NCHCH}_{2} \mathrm{CH}_{2}\right), 1.43\left(\mathrm{~s}, 9 \mathrm{H}, \mathrm{OC}\left(\mathrm{CH}_{3}\right)_{3}\right) .{ }^{13} \mathrm{C} \mathrm{NMR}$ $\left(101 \mathrm{MHz} \mathrm{CDCl}_{3}\right) \delta 171.1,170.2,150.7,150.0,143.3,143.2,141.5,141.4,128.2,127.5,125.3$, 125.2, 120.3, 120.2, 81.2, 69.3, 60.3, 46.7, 29.5, 28.2, 25.0. HRMS (ESI) calcd for $\mathrm{C}_{25} \mathrm{H}_{26} \mathrm{~N}_{2} \mathrm{NaO}_{6}{ }^{+}[\mathrm{M}+\mathrm{Na}]^{+}$473.1683; found 473.1686. IR ( $\left.v_{\max }, \mathrm{cm}^{-1}\right) 3253(\mathrm{w}), 2959(\mathrm{w}), 1807$ (w), 1749 (m), 1474 (w), 1448 (w), 1384 (m), 1372 (m), 1308 (m), 1244 (w), 1212 (w), 1161 (w), 1109 (w), $1071(\mathrm{w}), 1045(\mathrm{w}), 975$ (w), $956(\mathrm{w}), 917$ (s), $841(\mathrm{w}), 745(\mathrm{~s}), 693$ (w), 655 $(\mathrm{m}), 623(\mathrm{~m}) \cdot[\alpha]_{\mathrm{D}}^{20}=+10.2\left(\mathrm{c}=1.00, \mathrm{CHCl}_{3}\right)$.

\section{(S)-Benzyl 5-(2-(tert-butoxy)-2-oxoethyl)-2,4-dioxoimidazolidine-1-carboxylate (8r)}

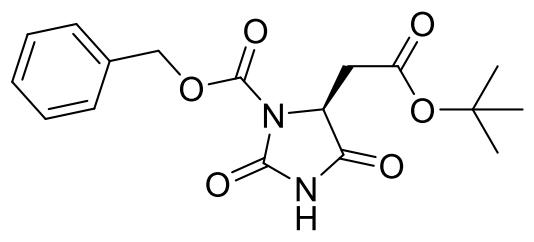


Starting from $7 \mathbf{r}(48.5 \mathrm{mg}, 0.150 \mathrm{mmol})$, the crude product was purified by preparative TLC (Heptane/Et $\left.{ }_{2} \mathrm{O}=10: 90\right)$ to afford $\mathbf{8 r}$ as white sticky solid (37.6 mg, $0.108 \mathrm{mmol}, 72 \%$ ). Rf: $0.55($ Heptane/Et $2 \mathrm{O}=10: 90) .{ }^{1} \mathrm{H}$ NMR $\left(400 \mathrm{MHz}, \mathrm{CDCl}_{3}\right) \delta 8.58(\mathrm{~s}, 1 \mathrm{H}, \mathrm{NH}), 7.52-7.31(\mathrm{~m}$, $5 \mathrm{H}, \mathrm{ArH}), 5.42-5.24\left(\mathrm{~m}, 2 \mathrm{H}, \mathrm{CH}_{2} \mathrm{Ar}\right), 4.53\left(\mathrm{dd}, J=5.2,2.9 \mathrm{~Hz}, 1 \mathrm{H}, \mathrm{NCHCH}_{2} \mathrm{CO}\right), 3.15$ (dd, $\left.J=17.1,5.2 \mathrm{~Hz}, 1 \mathrm{H}, \mathrm{NCHCH}_{2} \mathrm{CO}\right), 3.01\left(\mathrm{dd}, J=17.1,2.9 \mathrm{~Hz}, 1 \mathrm{H}, \mathrm{NCHCH}_{2} \mathrm{CO}\right), 1.38(\mathrm{~s}, 9 \mathrm{H}$, $\left.\mathrm{OC}\left(\mathrm{CH}_{3}\right)_{3}\right) .{ }^{13} \mathrm{C} \mathrm{NMR}\left(101 \mathrm{MHz}, \mathrm{CDCl}_{3}\right) \delta 170.4,167.9,151.6,150.1,134.8,128.8,128.8$, 128.4, 82.7, 69.1, 57.7, 35.1, 28.0. HRMS (ESI) calcd for $\mathrm{C}_{17} \mathrm{H}_{20} \mathrm{~N}_{2} \mathrm{NaO}_{6}{ }^{+}[\mathrm{M}+\mathrm{Na}]^{+} 371.1214$; found 371.1218. IR $\left(v_{\max }, \mathrm{cm}^{-1}\right) 3263(\mathrm{w}), 2979(\mathrm{w}), 2903(\mathrm{w}), 1815(\mathrm{w}), 1751(\mathrm{~m}), 1460(\mathrm{w})$, 1372 (w), 1359 (w), 1309 (w), 1150 (w), 1106 (w), 1049 (w), 992 (w), 910 (s), 916 (s), 834 $(\mathrm{w}), 739(\mathrm{~s}), 695(\mathrm{w}), 651(\mathrm{w}) .[\alpha]_{\mathrm{D}}^{20}=+28.7(\mathrm{c}=1.00$, Ethanol).

(S)-tert-Butyl 5-((benzyloxy)methyl)-2,4-dioxoimidazolidine-1-carboxylate (8s)

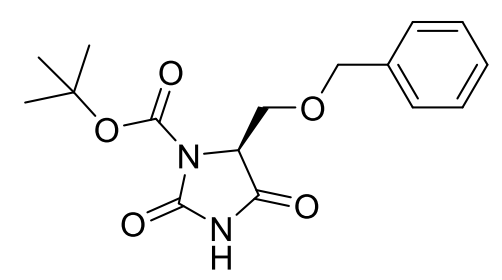

Starting from $7 \mathbf{s}(53.5 \mathrm{mg}, 0.150 \mathrm{mmol})$, the crude product was purified by preparative TLC (Heptane/Et ${ }_{2} \mathrm{O}=20: 80$ ) to afford $8 \mathbf{s}$ as colorless sticky solid (36 mg, $95 \mu \mathrm{mol}, 64 \%$ ). Rf: 0.60 $($ Heptane/Et $2 \mathrm{O}=20: 80) .{ }^{1} \mathrm{H}$ NMR $\left(400 \mathrm{MHz}, \mathrm{CDCl}_{3}\right) \delta 7.60(\mathrm{~s}, 1 \mathrm{H}, \mathrm{NH}), 7.39-7.19(\mathrm{~m}, 5 \mathrm{H}$, $\mathrm{ArH}), 4.60-4.42\left(\mathrm{~m}, 3 \mathrm{H}, \mathrm{NCHCH}_{2} \mathrm{OCH}_{2}\right), 4.03$ (dd, $\left.J=10.0,2.7 \mathrm{~Hz}, 1 \mathrm{H}, \mathrm{NCHCH}_{2}\right), 3.90$ $\left(\mathrm{dd}, J=10.0,1.8 \mathrm{~Hz}, 1 \mathrm{H}, \mathrm{NCHCH}_{2}\right), 1.49\left(\mathrm{~s}, 9 \mathrm{H}, \mathrm{OC}\left(\mathrm{CH}_{3}\right)_{3}\right) .{ }^{13} \mathrm{C} \mathrm{NMR}\left(101 \mathrm{MHz}, \mathrm{CDCl}_{3}\right) \delta$ 169.1, 151.3, 148.2, 137.1, 128.5, 128.0, 127.6, 84.5, 73.5, 66.0, 61.8, 28.0. HRMS (ESI) calcd for $\mathrm{C}_{16} \mathrm{H}_{20} \mathrm{~N}_{2} \mathrm{NaO}_{5}^{+}[\mathrm{M}+\mathrm{Na}]^{+}$343.1264; found 343.1266. IR $\left(v_{\max }, \mathrm{cm}^{-1}\right) 3661(\mathrm{w}), 3236(\mathrm{w})$, 2985 (w), 2903 (w), 2760 (w), 1812 (w), 1751 (m), 1611 (w), 1514 (w), 1453 (w), 1369 (m), 1317 (w), 1280 (w), 1245 (w), 1216 (w), 1155 (w), 1104 (w), 1076 (w), 1052 (w), 994 (w), 914 $(\mathrm{s}), 848(\mathrm{w}), 745(\mathrm{~s}), 703(\mathrm{w}), 670(\mathrm{w}), 651(\mathrm{w}), 618(\mathrm{w}) .[\alpha]_{\mathrm{D}}{ }^{20}=+4.0\left(\mathrm{c}=1.00, \mathrm{CHCl}_{3}\right)$.

(S)-tert-Butyl 5-cyclopropyl-2,4-dioxoimidazolidine-1-carboxylate (8t)<smiles>CC(C)(C)OC(=O)N1C(=O)NC(=O)[C@H]1C1CC1</smiles> 
Starting from $7 \mathbf{t}(32.3 \mathrm{mg}, 0.150 \mathrm{mmol})$, the crude product was purified by preparative TLC $(\mathrm{DCM} / \mathrm{EtOAc}=80: 20)$ to afford $8 \mathrm{t}$ as colorless solid $(23.5 \mathrm{mg}, 98.0 \mu \mathrm{mol}, 65 \%) . \mathrm{Rf}=0.30$ (DCM/EtOAc: 4/1) M.p. $145-146{ }^{\circ} \mathrm{C} .{ }^{1} \mathrm{H}$ NMR (400 MHz, $\left.\mathrm{CDCl}_{3}\right) \delta 7.88$ (bs, 1H, NH), 4.19 (d, $J=7.0 \mathrm{~Hz}, 1 \mathrm{H}, \mathrm{NCHCO}), 1.57$ (s, 9H, Boc), $1.30-1.23\left(\mathrm{~m}, 1 \mathrm{H}, \mathrm{CH}\left(\mathrm{CH}_{2}\right)_{2}\right), 0.80-0.70$ $\left(\mathrm{m}, 1 \mathrm{H}, \mathrm{CH}_{2}\right), 0.70-0.63\left(\mathrm{~m}, 2 \mathrm{H}, \mathrm{CH}_{2}\right), 0.63-0.52\left(\mathrm{~m}, 1 \mathrm{H}, \mathrm{CH}_{2}\right) .{ }^{13} \mathrm{C} \mathrm{NMR}\left(101 \mathrm{MHz}, \mathrm{CDCl}_{3}\right)$ $\delta 169.8,151.5,148.6,84.7,63.0,28.2,12.8,3.7,1.8$. IR (vmax, cm-1) $3262(\mathrm{~m}), 2983(\mathrm{~m})$, 1808 (s), 1751 (s), 1370 (s), 1332 (s), 1155 (s), 1098 (s), 1028 (m), 913 (m), 850 (m), 767 (m), 736 (s), 666 (m), 654 (m). HRMS (ESI) calcd for $\mathrm{C}_{11} \mathrm{H}_{16} \mathrm{~N}_{2} \mathrm{NaO}_{4}{ }^{+}[\mathrm{M}+\mathrm{Na}]^{+}$263.1002; found 263.1007. $[\alpha]_{\mathrm{D}}^{20}=+24.2\left(\mathrm{c}=0.4, \mathrm{CHCl}_{3}\right)$.

\section{(S)-Tetrahydro-1H-pyrrolo[1,2-c]imidazole-1,3(2H)-dione (8u)}<smiles>O=C1NC(=O)N2CCCC12</smiles>

Starting from $7 \mathbf{u}(17.3 \mathrm{mg}, 0.150 \mathrm{mmol})$, the crude product was purified by preparative TLC (Heptane/Et ${ }_{2} \mathrm{O}=20: 80$ ) to afford $8 \mathbf{u}$ as white solid (13 mg, $93 \mu \mathrm{mol}, 62 \%$ ). Rf: 0.13 (Heptane/Et $2 \mathrm{O}=20: 80) .{ }^{1} \mathrm{H}$ NMR (400 MHz, DMSO-d6) $\delta 10.75$ (s, 1H, NH), 4.11 (dd, $J=$ 9.0, 7.5 Hz, 1H, NCH), 3.46 (dt, $J=10.8,7.6 \mathrm{~Hz}, 1 \mathrm{H}, \mathrm{NCH}_{2}$ ), 3.04 (ddd, $J=10.8,7.9,4.8 \mathrm{~Hz}$, $\left.1 \mathrm{H}, \mathrm{NCH}_{2}\right), 2.10-2.01\left(\mathrm{~m}, 1 \mathrm{H}, \mathrm{NCH}_{2} \mathrm{CH}_{2} \mathrm{CH}_{2}\right), 2.00-1.85\left(\mathrm{~m}, 2 \mathrm{H}, \mathrm{NCH}_{2} \mathrm{CH}_{2} \mathrm{CH}_{2}\right), 1.71-$ $1.58\left(\mathrm{~m}, 1 \mathrm{H}, \mathrm{NCH}_{2} \mathrm{CH}_{2} \mathrm{CH}_{2}\right) .{ }^{13} \mathrm{C}$ NMR (101 MHz, DMSO-d6) $\delta$ 175.4, 161.0, 64.0, 44.9, 26.7, 26.6. HRMS (ESI) calcd for $\mathrm{C}_{4} \mathrm{H}_{7} \mathrm{~N}_{2} \mathrm{O}_{2}{ }^{+}[\mathrm{M}+\mathrm{H}]^{+} 115.0502$; found 115.0499. $[\alpha]_{\mathrm{D}}{ }^{20}=-118.11$ ( $c=0.51$, Ethanol). The characterization data is in accordance with reported literature values. ${ }^{[8]}$

\section{Benzyl 2,4-dioxoimidazolidine-1-carboxylate (8v)}

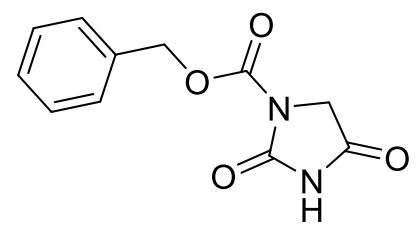

Starting from $\mathbf{7 v}(31.4 \mathrm{mg}, 0.150 \mathrm{mmol})$, the crude product was purified by preparative TLC $(\mathrm{DCM} / \mathrm{MeOH}=90: 10)$ to afford $\mathbf{8 v}$ as white sticky solid (31 mg, $0.13 \mathrm{mmol}, 88 \%$ ). Rf: 0.69 $(\mathrm{DCM} / \mathrm{MeOH}=90: 10) .{ }^{1} \mathrm{H} \mathrm{NMR}\left(400 \mathrm{MHz}, \mathrm{CDCl}_{3}\right) \delta 7.45-7.35$ (m, 5H, $\left.\mathrm{ArH}\right), 5.32(\mathrm{~s}, 2 \mathrm{H}$, $\left.\mathrm{OCH}_{2} \mathrm{Ar}\right), 4.32\left(\mathrm{~s}, 2 \mathrm{H}, \mathrm{NCH}_{2}\right) .{ }^{13} \mathrm{C} \mathrm{NMR}\left(101 \mathrm{MHz}, \mathrm{CDCl}_{3}\right) \delta 166.8,150.8,149.6,134.5$,

\footnotetext{
${ }^{[8]}$ Kumar, V.; Rana, H.; Sankolli, R.; Kaushik, M. P. Tetrahedron Lett. 2011, 52, 6148.
} 
128.9, 128.8, 128.5, 69.1, 49.9. HRMS (ESI) calcd for $\mathrm{C}_{11} \mathrm{H}_{10} \mathrm{~N}_{2} \mathrm{NaO}_{4}{ }^{+}[\mathrm{M}+\mathrm{Na}]^{+}$257.0533; found 257.0540. IR $\left(v_{\max }, \mathrm{cm}^{-1}\right) 3244(\mathrm{w}), 2998(\mathrm{w}), 2903(\mathrm{w}), 1815(\mathrm{w}), 1764(\mathrm{~m}), 1435(\mathrm{w})$, $1391(w), 1353$ (w), $1290(w), 1201(w), 1106$ (w), 1056 (w), 973 (w), 916 (s), 834 (w), 746 $(\mathrm{s}), 651(\mathrm{w}), 632(\mathrm{w})$.

Tert-butyl 5,5-dimethyl-2,4-dioxoimidazolidine-1-carboxylate (8w)<smiles>CC(C)(C)OC(=O)N1C(=O)NC(=O)C1(C)C</smiles>

Starting from $7 \mathbf{w}(30.5 \mathrm{mg}, 0.150 \mathrm{mmol})$, the crude product was purified by preparative TLC (Heptane $\left./ \mathrm{Et}_{2} \mathrm{O}=25: 75\right)$ to afford $\mathbf{8 w}$ as white solid $(19.0 \mathrm{mg}, 83.0 \mu \mathrm{mol}, 56 \%)$. Rf = 0.45 (Heptane/Et $\left.\mathrm{E}_{2} \mathrm{O}=25: 75\right)$ M.p. $157-159{ }^{\circ} \mathrm{C} .{ }^{1} \mathrm{H} \mathrm{NMR}\left(400 \mathrm{MHz}, \mathrm{CDCl}_{3}\right) \delta 7.94$ (bs, $\left.1 \mathrm{H}, \mathrm{NH}\right)$, $1.64\left(\mathrm{~s}, 6 \mathrm{H}, \mathrm{NCH}\left(\mathrm{CH}_{3}\right)_{2}\right), 1.57$ (s, 9H, $\left.\mathrm{C}\left(\mathrm{CH}_{3}\right)\right) .{ }^{13} \mathrm{C} \mathrm{NMR}\left(101 \mathrm{MHz}, \mathrm{CDCl}_{3}\right) \delta 174.9,151.3$, 148.5, 84.5, 64.7, 28.2, 23.2. IR $\left(v_{\max }, \mathrm{cm}^{-1}\right) 3669$ (w), 3245 (w), 2983 (s), $2906(\mathrm{~m}), 1813(\mathrm{~m})$, 1752 (s), 1459 (w), 1388 (m), 1369 (s), 1330 (s), 1255 (m), 1228 (m), 1163 (m), 1078 (s), 1073 (s), 1063 (s), 940 (w), 909 (w), 845 (w). HRMS (ESI/QTOF) m/z: [M+Na] ${ }^{+}$Calcd for $\mathrm{C}_{10} \mathrm{H}_{16} \mathrm{~N}_{2} \mathrm{NaO}_{4}{ }^{+}$251.1002; Found 251.1005. 


\section{Hydantoin hydrogenolysis deprotection:}

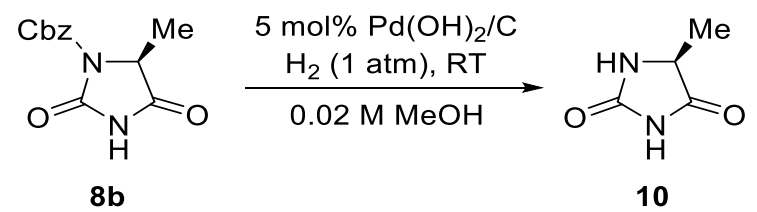

A flame dried $50 \mathrm{~mL}$ flask containing palladium hydroxide on carbon $(4.3 \mathrm{mg}, 6.1 \mu \mathrm{mol}, 5$ mol\%) and equipped with a teflon coated stirring bar, was placed under nitrogen atmosphere (vaccum / $\mathrm{N}_{2}$ exchange). A solution of the hydantoin $\mathbf{8 b}$ (30 $\mathrm{mg}, 0.12 \mathrm{mmol}, 1$ equiv) in dry $\mathrm{MeOH}(6.0 \mathrm{~mL}, 0.02 \mathrm{M})$ was added. The flask was then placed under hydrogen atmosphere (vaccum / $\mathrm{H}_{2}$ cycles) and the solution was stirred at room temperature for $4 \mathrm{~h}$. The solution was then filtrated over a hplc filter and concentrated under reduced pressure to provide the (S)-5methylimidazolidine-2,4-dione $\mathbf{1 0}$ (14 $\mathrm{mg}, 0.12 \mathrm{mmol}, 100 \%$ yield $)$ as a white solid.

\section{(S)-5-Methylimidazolidine-2,4-dione (10)}<smiles>CC1NC(=O)NC1=O</smiles>

${ }^{1} \mathrm{H}$ NMR (400 MHz, DMSO-d6) $\delta 10.57$ (s, 1H, NH), 7.87 (s, 1H, NH), 4.02 (qd, J = 6.9, 1.2 $\left.\mathrm{Hz}, 1 \mathrm{H}, \mathrm{NCHCH}_{3}\right), 1.21\left(\mathrm{~d}, J=6.9 \mathrm{~Hz}, 3 \mathrm{H}, \mathrm{NCHCH}_{3}\right) .{ }^{13} \mathrm{C} \mathrm{NMR}(101 \mathrm{MHz}, \mathrm{DMSO}-\mathrm{d} 6) \delta$ 176.8, 157.1, 53.3, 17.2. HRMS (ESI) calcd for $\mathrm{C}_{4} \mathrm{H}_{7} \mathrm{~N}_{2} \mathrm{O}_{2}{ }^{+}[\mathrm{M}+\mathrm{H}]^{+}$115.0502; found 115.0501. $[\alpha]_{\mathrm{D}}{ }^{20}=-30.7(\mathrm{c}=0.43$, Ethanol). The characterization data is in accordance with reported literature values. ${ }^{[9]}$

${ }^{[9]}$ Konnert, L.; Reneaud, B.; Marcia de Figueiredo, R.; Campagne, J. M.; Lamaty, F.; Martinez, J.; Colacino, E. J. Org. Chem. 2014, 79, 10132. 


\section{Procedure for hydantoin gram scale synthesis:}

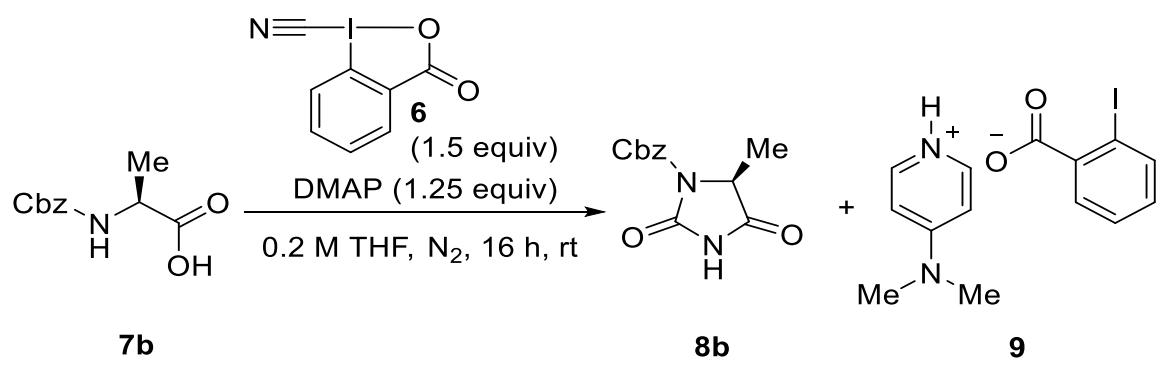

In a flame dried $50 \mathrm{~mL}$ balloon containing a teflon coated stirring bar were added $7 \mathbf{b}(1.0 \mathrm{~g}, 4.5$ mmol, 1 equiv), CBX 6 (1.84 g, $6.72 \mathrm{mmol}, 1.5$ equiv) and N,N-dimethylpyridin-4-amine (0.68 g, 5.6 mmol, 1.25 equiv). Then, the test tube was evacuated and backfilled 3 times with $\mathrm{N}_{2}$. Then dry THF (22.4 mL) was added, and the resulting white mixture was stirred for $16 \mathrm{~h}$. Addition of $20 \mathrm{~mL}$ of pentane to the reaction mixture lead to full precipitation of salt $\mathbf{8}$. Then, the mixture was filtrated over a plug of celite to remove the main part of the salt formed. The celite plug was washed with $2 \times 20 \mathrm{~mL}$ of THF:pentane (1:1) and the filtrate was evaporated to give the crude hydantoin in $70 \%$ purity. The pad was then washed with $50 \mathrm{~mL}$ of DCM, and after concentration under reduced pressure salt 9 was recovered $(1.75 \mathrm{~g}, 4.73 \mathrm{mmol}, 84 \%)$. The crude material was then purified by column (full DCM to DCM/Ethyl acetate 80:20) to provide the (S)-benzyl 5-methyl-2,4-dioxoimidazolidine-1-carboxylate $\mathbf{8 b}(1.2 \mathrm{~g}, 4.5 \mathrm{mmol}, 100 \%$ yield) with $93 \%$ purity. 


\section{General procedure for hydantoin synthesis from peptides:}

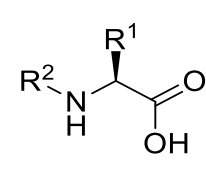

11

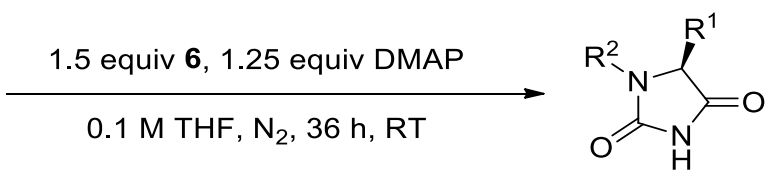

12

Dry THF $(1.5 \mathrm{~mL})$ was added in a flame dried $1 \mathrm{~mL}$ test tube containing a teflon coated stirring bar, the peptide 11 ( $0.15 \mathrm{mmol}, 1.0$ equiv), CBX reagent (6) (61 mg, $0.23 \mathrm{mmol}, 1.5$ equiv) and DMAP (23.0 mg, 0.188 mmol, 1.25 equiv) under $\mathrm{N}_{2}$ (vaccum / $\mathrm{N}_{2}$ exchange). The resulting mixture was stirred for $36 \mathrm{~h}$ at room temperature. After completion of the reaction, the reaction mixture was concentrated under reduced pressure. Purification was performed by preparative TLC (Heptane/ $\mathrm{Et}_{2} \mathrm{O}$ ) affording the corresponding hydantoin 12.

\section{Benzyl ((S)-1-((S)-5-methyl-2,4-dioxoimidazolidin-1-yl)-1-oxopropan-2-yl)carbamate} (12a)

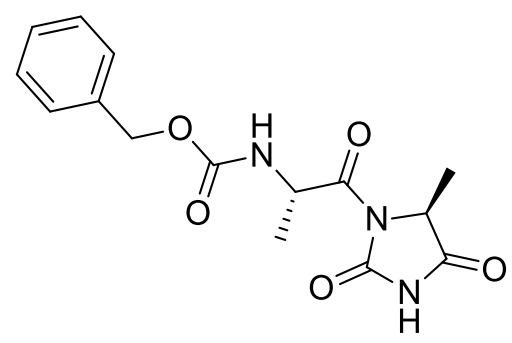

Starting from 11a (44 $\mathrm{mg}, 0.15 \mathrm{mmol}$ ), the crude product was purified by preparative TLC (Heptane/Et $2 \mathrm{O}=10: 90$ ) to afford 12a as white sticky solid (38 mg, $0.12 \mathrm{mmol}, 80 \%$ ). Rf: 0.5 (Heptane/Et $\left.{ }_{2} \mathrm{O}=10: 90\right) .{ }^{1} \mathrm{H} \mathrm{NMR}\left(400 \mathrm{MHz}, \mathrm{CDCl}_{3}\right.$, mixture of rotamers not fully resolved, only the major rotamer is described) $\delta 8.24(\mathrm{~s}, 1 \mathrm{H}, \mathrm{NH}), 7.40-7.28(\mathrm{~m}, 5 \mathrm{H}, \mathrm{ArH}), 5.52-5.26$ $\left(\mathrm{m}, 2 \mathrm{H}, \mathrm{OCH}_{2} \mathrm{Ar}\right), 5.17-5.04\left(\mathrm{~m}, 2 \mathrm{H}, \mathrm{NCHCH}_{3}\right), 4.68-4.45(\mathrm{~m}, 1 \mathrm{H}, \mathrm{NH}), 1.74-1.51$ (m, $\left.3 \mathrm{H}, \mathrm{CH}_{3}\right), 1.51-1.38\left(\mathrm{~m}, 3 \mathrm{H}, \mathrm{CH}_{3}\right) .{ }^{13} \mathrm{C} \mathrm{NMR}\left(101 \mathrm{MHz}, \mathrm{CDCl}_{3}\right.$, mixture of rotamers not fully resolved, only the major rotamer is described) $\delta 172.9,171.7,155.8,152.0,136.3,128.7,128.4$, 128.2, 67.2, 57.2, 50.8, 18.2, 16.2. HRMS (ESI) calcd for $\left.\mathrm{C}_{15} \mathrm{H}_{17} \mathrm{~N}_{3} \mathrm{NaO}_{5}{ }^{+} \mathrm{M}+\mathrm{Na}\right]^{+}$342.1060; found 342.1062. IR ( $\left.v_{\max }, \mathrm{cm}^{-1}\right) 3658(\mathrm{w}), 3349$ (w), 2976 (m), 2919 (w), 2894 (m), 1918 (w), 1810 (w), 1747 (w), 1695 (w), 1643 (w), 1456 (w), 1385 (w), 1329 (w), 1275 (w), 1240 (w), 1155 (w), 1087 (m), 1048 (m), 914 (s), 883 (w), 839 (w), 750 (s), 682 (w), 653 (w), 632 (w). $[\alpha]_{\mathrm{D}}^{20}=-9.7\left(\mathrm{c}=1.00, \mathrm{CHCl}_{3}\right)$. Chiral HPLC conditions: de $=72 \%$; Chiralpak ID 80:20 Hexane/iPrOH, $1.0 \mathrm{~mL} / \mathrm{min}, 60 \mathrm{~min} . \operatorname{tr}=27.1 \mathrm{~min}, \lambda=210 \mathrm{~cm}^{-1}$. 


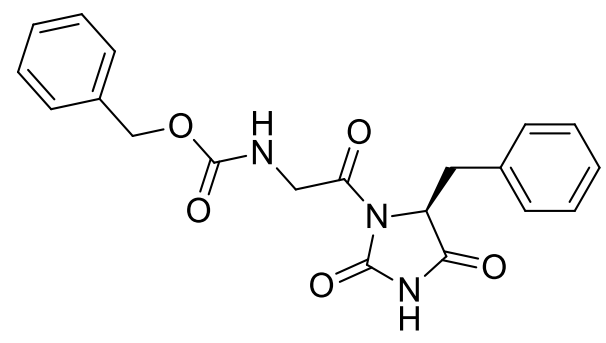

Starting from $11 \mathrm{~b}(53.5 \mathrm{mg}, 0.150 \mathrm{mmol})$, the crude product was purified by preparative TLC (Heptane/Et ${ }_{2} \mathrm{O}=10: 90$ ) to afford 12b as white sticky solid (36 mg, $95 \mu \mathrm{mol}, 64 \%$ ). Rf: 0.65 (Heptane/Et $2 \mathrm{O}=10: 90) .{ }^{1} \mathrm{H}$ NMR (400 MHz, $\left.\mathrm{CDCl}_{3}\right) \delta 7.49-6.88(\mathrm{~m}, 10 \mathrm{H}, \mathrm{ArH}), 5.55-5.40$ (m, 1H, NH), 5.17 (s, 2H, OCH $\left.\mathrm{OH}_{2} \mathrm{Ar}\right), 4.82$ (ddd, J=5.7, 4.5, $2.5 \mathrm{~Hz}, 1 \mathrm{H}, \mathrm{NCHCH}_{2}$ ), 4.54 (ddd, $J=19.3,8.4,5.9 \mathrm{~Hz}, 1 \mathrm{H}, \mathrm{NCH}_{2} \mathrm{CO}$ ), $4.40-4.23$ (m, 1H, $\mathrm{NCH}_{2} \mathrm{CO}$ ), 3.53 (ddd, $J=14.2,5.8$, $\left.1.8 \mathrm{~Hz}, 1 \mathrm{H}, \mathrm{NCHCH}_{2} \mathrm{Ar}\right), 3.29$ (dd, $\left.J=14.0,2.5 \mathrm{~Hz}, 1 \mathrm{H}, \mathrm{NCHCH}_{2} \mathrm{Ar}\right) .{ }^{13} \mathrm{C} \mathrm{NMR}(101 \mathrm{MHz}$, $\left.\mathrm{CDCl}_{3}\right) \delta 170.4,168.9,156.6,152.3,136.2,133.1,129.7,129.0,128.7,128.5,128.3,127.9$, 67.5, 61.4, 46.4, 34.3. HRMS (ESI) calcd for $\mathrm{C}_{20} \mathrm{H}_{19} \mathrm{~N}_{3} \mathrm{NaO}_{5}{ }^{+}[\mathrm{M}+\mathrm{Na}]^{+}$404.1217; found 404.1221. IR ( $\left.v_{\max }, \mathrm{cm}^{-1}\right) 3670(\mathrm{w}), 2985(\mathrm{w}), 2901(\mathrm{w}), 1801(\mathrm{w}), 1740(\mathrm{w}), 1711(\mathrm{w}), 1615$ (w), $1510(\mathrm{w}), 1456(\mathrm{w}), 1388(\mathrm{w}), 1268(\mathrm{w}), 1245(\mathrm{w}), 1174(\mathrm{w}), 1134(\mathrm{w}), 1059(\mathrm{w}), 989(\mathrm{w})$, $916(\mathrm{~s}), 843(\mathrm{w}), 743(\mathrm{~s}), 700(\mathrm{w}), 656(\mathrm{w}), 632(\mathrm{w}) \cdot[\alpha]_{\mathrm{D}}{ }^{20}=+42.1\left(\mathrm{c}=0.52, \mathrm{CHCl}_{3}\right)$. Chiral HPLC conditions: ee $=44 \%$; Chiralpak ID 80:20 Hexane/iPrOH, $1.0 \mathrm{~mL} / \mathrm{min}, 60 \mathrm{~min} . \mathrm{tr}=40.7$ $\min , \lambda=210 \mathrm{~cm}^{-1}$. 


\section{Possible transition states for cyanation}

Concerning transfer of the cyanide group, several pathways can be proposed (Scheme 2). A first possibility would be nucleophilic attack on the carbon of the cyanide group, however when considering that the most electrophilic position is usually on the iodine for this type of reagent, this mechanism is less probable. ${ }^{[10]}$ Consequently, attack on the iodine atom, followed by reductive elimination on iodine, appears more feasible. Mechanisms involving a single electron transfer and subsequent formation of radical intermediates also constitute an alternative when considering the strong oxidizing properties of hypervalent iodine reagents. Finally, as recently demonstrated by our group, ${ }^{[11]}$ a concerted mechanism via a three-atom transition state is also possible. Further computational studies could be done to better highlight the transition state involved.

Scheme 2. Speculative transition states for the cyanide group transfer.

A. Attack on carbon<smiles></smiles>

B. Attack on iodine<smiles>[R]C(NC(=O)c1ccccc1C(=O)O)C(=O)OI(C#N)c1ccccc1C[AsH3-]</smiles>

C. Radical pathway

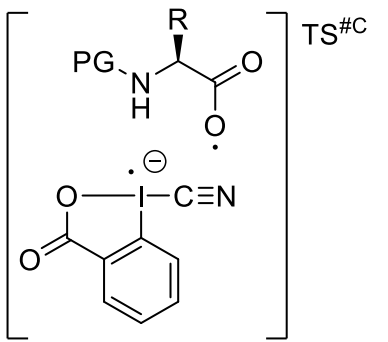

D. Concerted pathway<smiles></smiles>

\footnotetext{
${ }^{10}$ Li, Y.; Hari, D. P.; Vita, M. V.; Waser, J. Angew. Chem. Int. Ed. 2016, 55, 4436.
}

${ }^{11}$ Frei, R.; Courant, T.; Wodrich, M. D.; Waser, J. Chem. Eur. J. 2015, $21,2662$. 
5. Spectra of New Compounds

${ }^{1} \mathbf{H}$-NMR (400 MHz, $\mathrm{CDCl}_{3}$ ) of compound sa

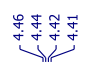

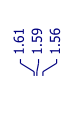
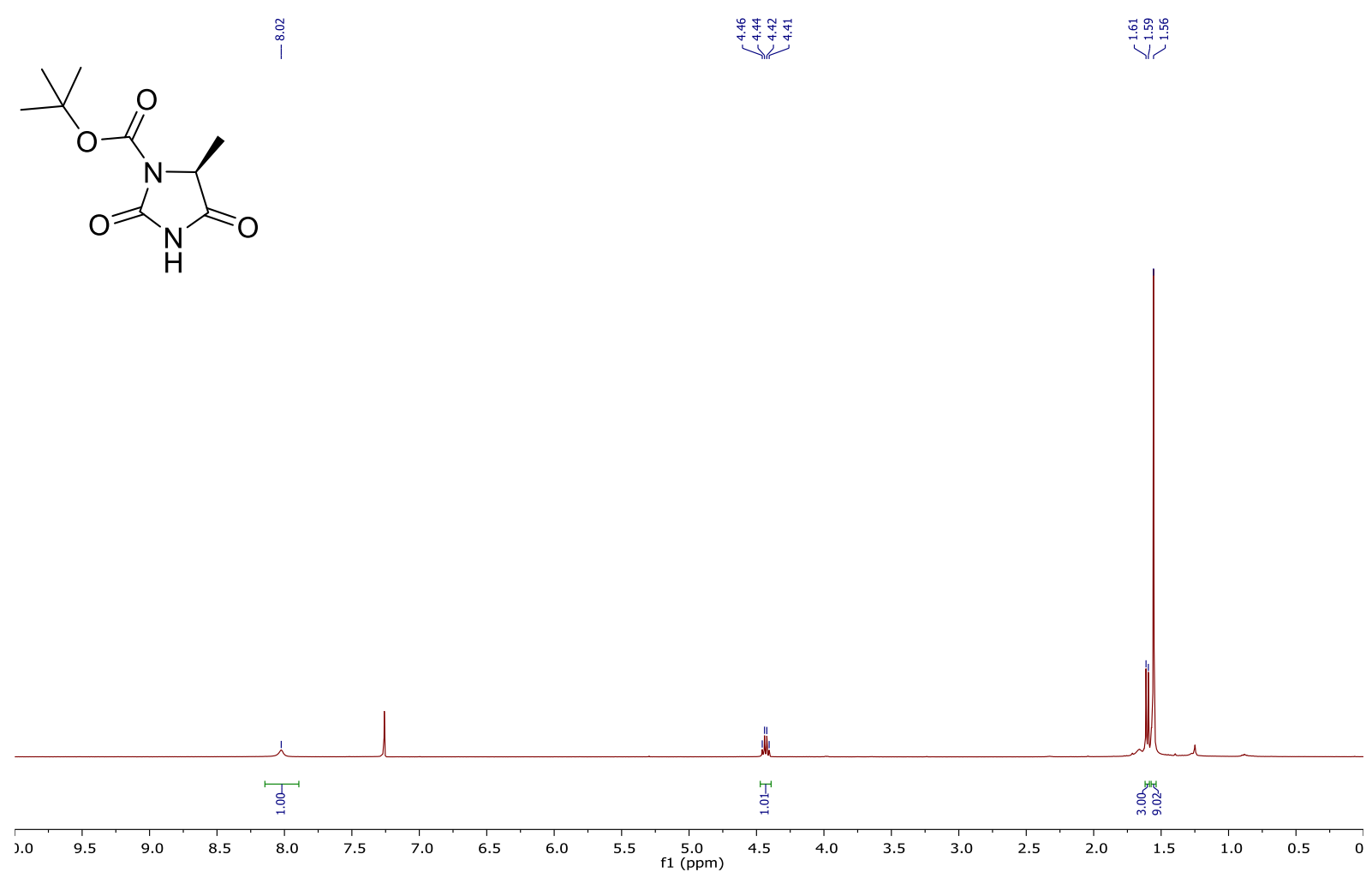

${ }^{13} \mathbf{C}$-NMR $\left(100 \mathrm{MHz}, \mathrm{CDCl}_{3}\right)$ of compound Ba
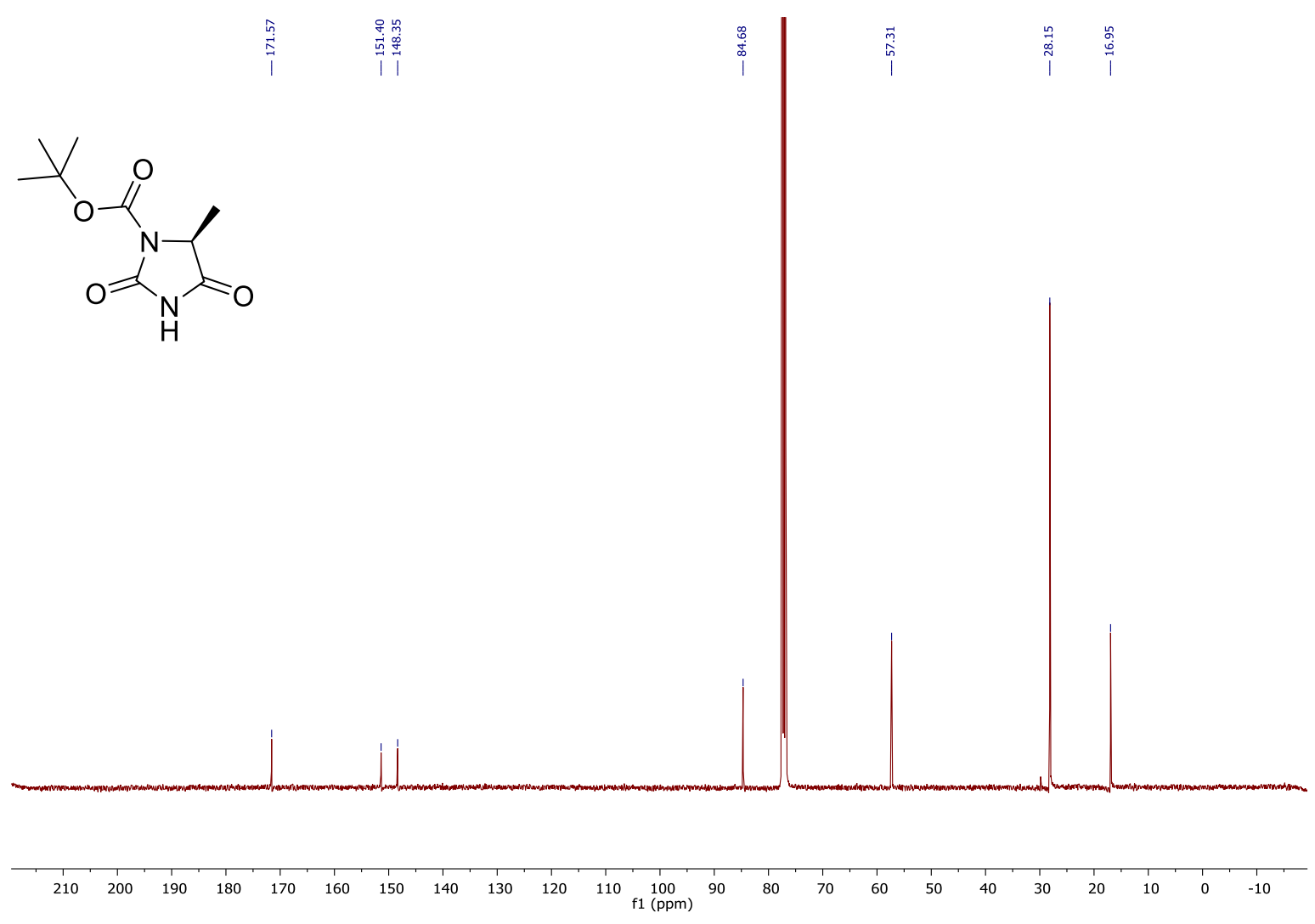

S33 


\section{IR of compound $\mathbf{8 a}$}

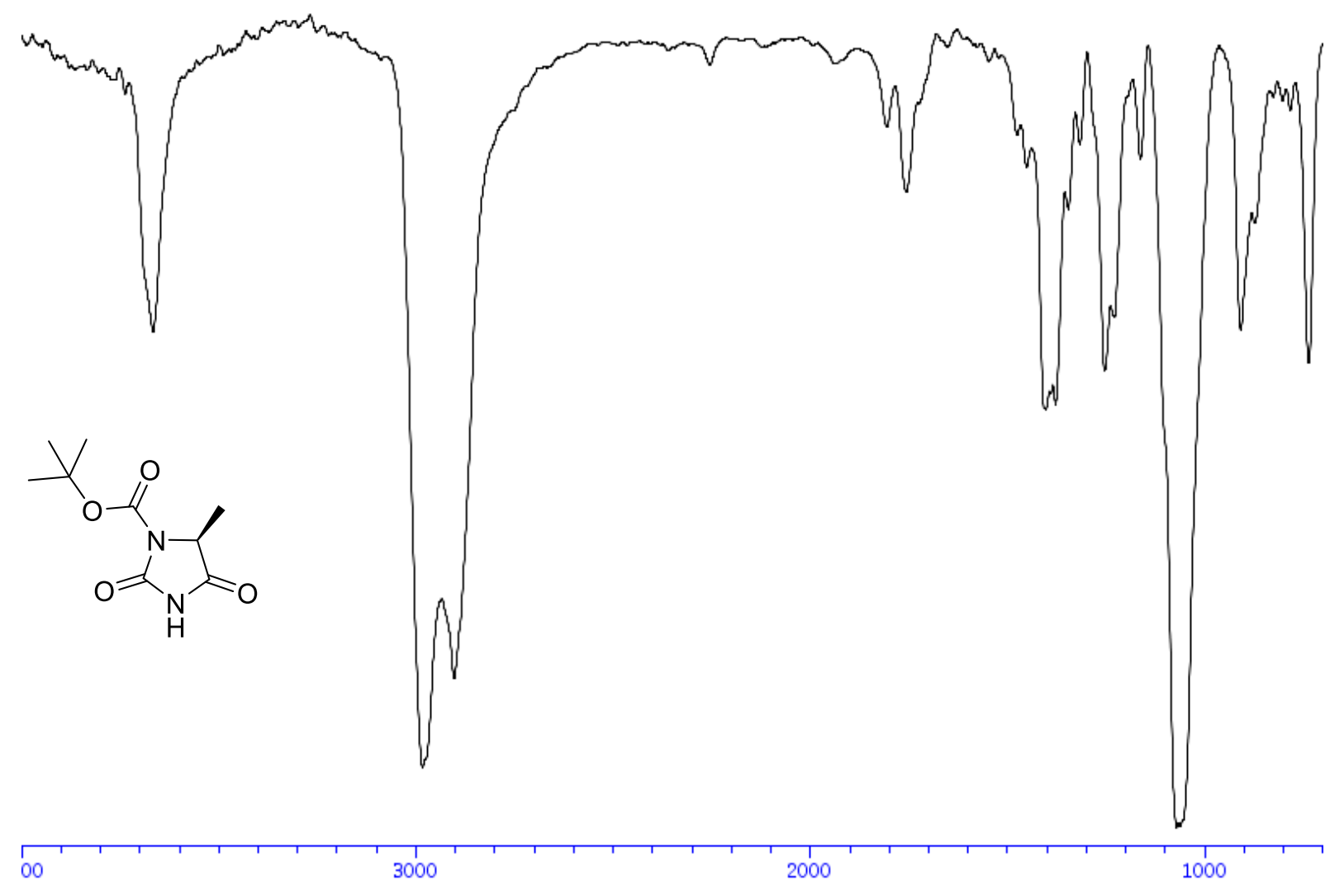


${ }^{\mathbf{1}} \mathbf{H}$-NMR (400 MHz, $\mathrm{CDCl}_{3}$ ) of compound $\mathbf{8 b}$
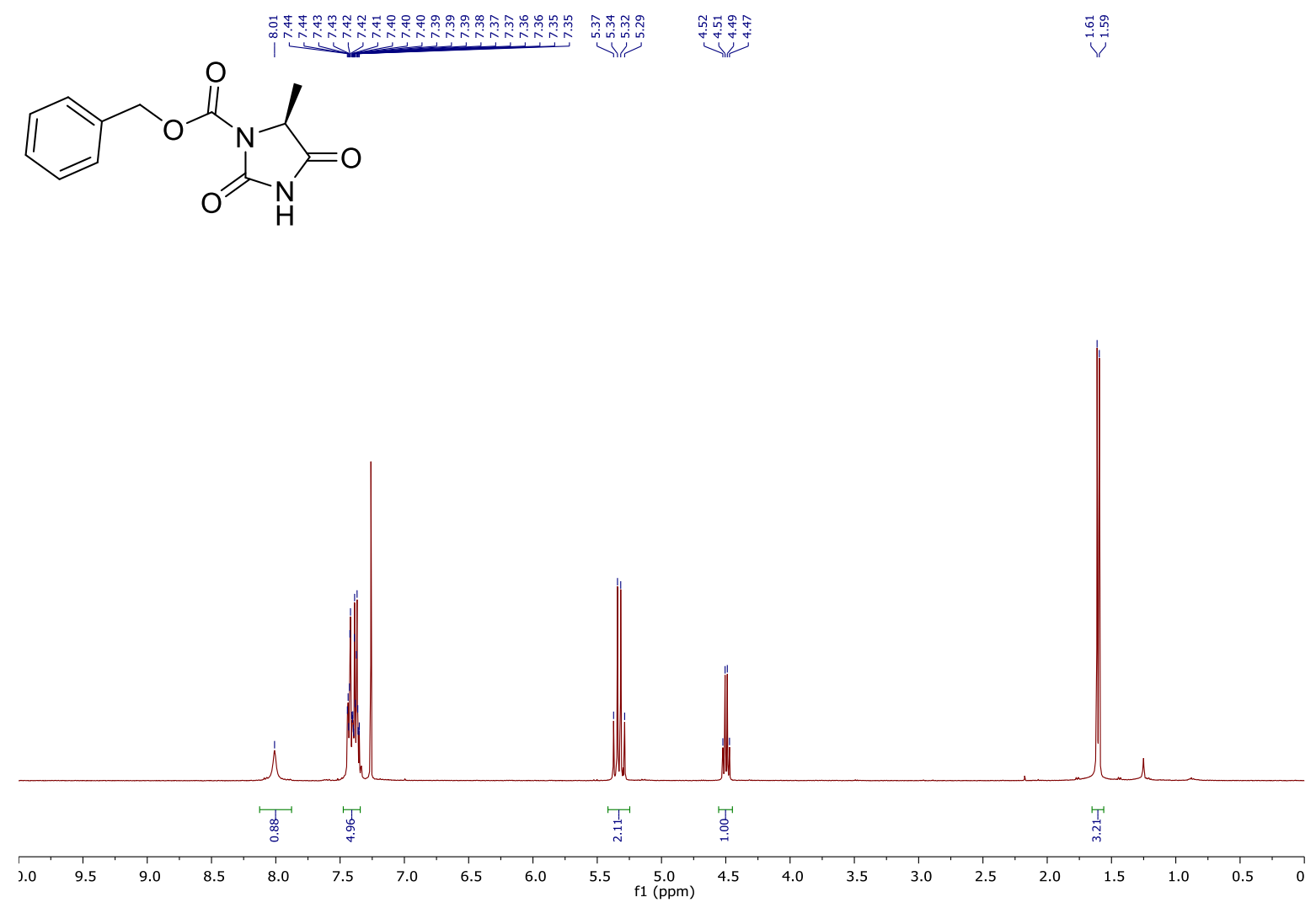

${ }^{13} \mathbf{C}$-NMR (100 MHz, $\mathrm{CDCl}_{3}$ ) of compound $\mathbf{8 b}$

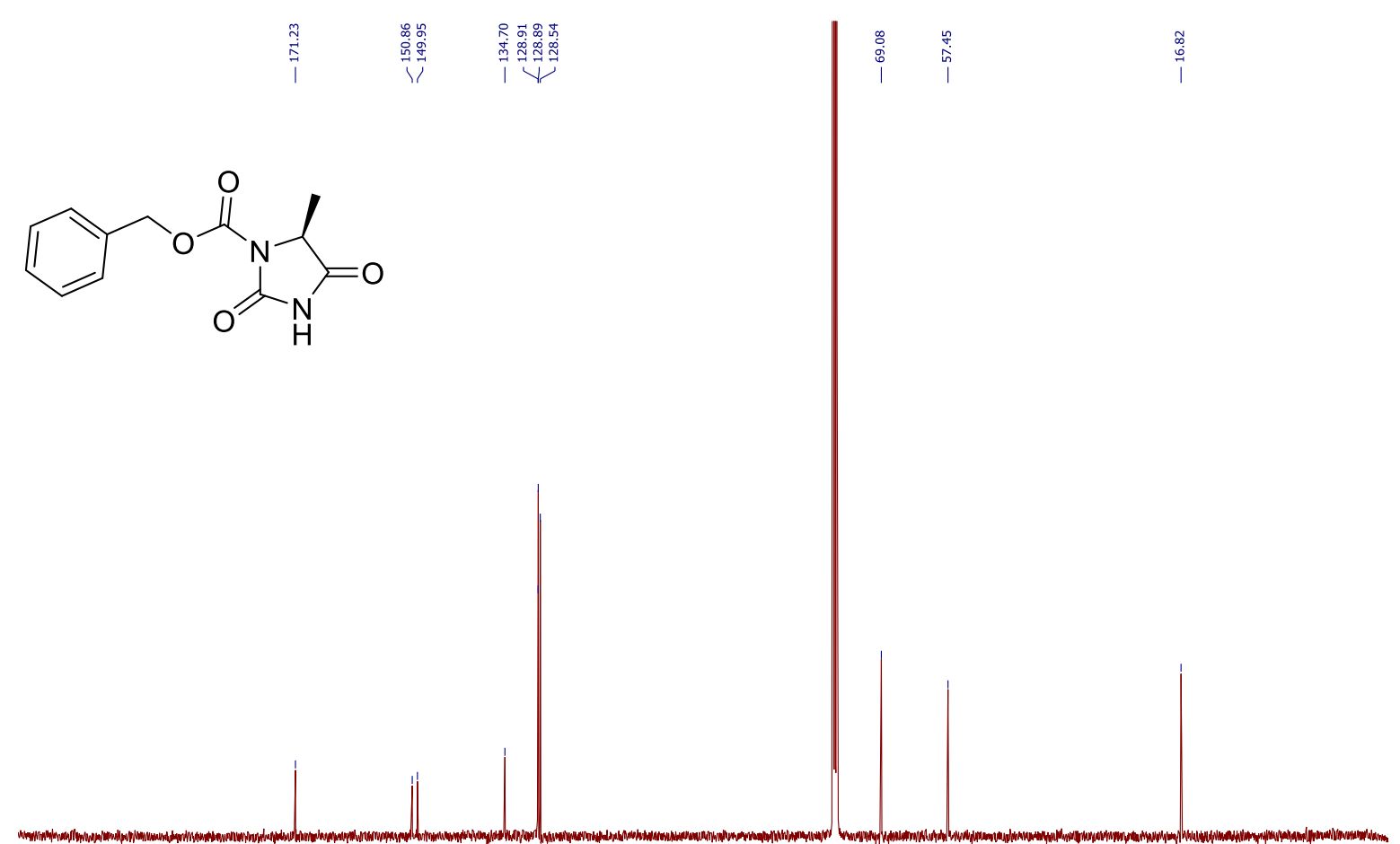

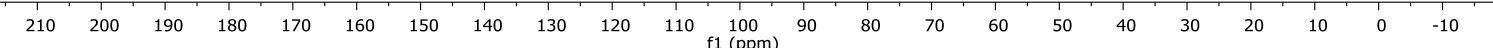


IR of compound $\mathbf{8 b}$

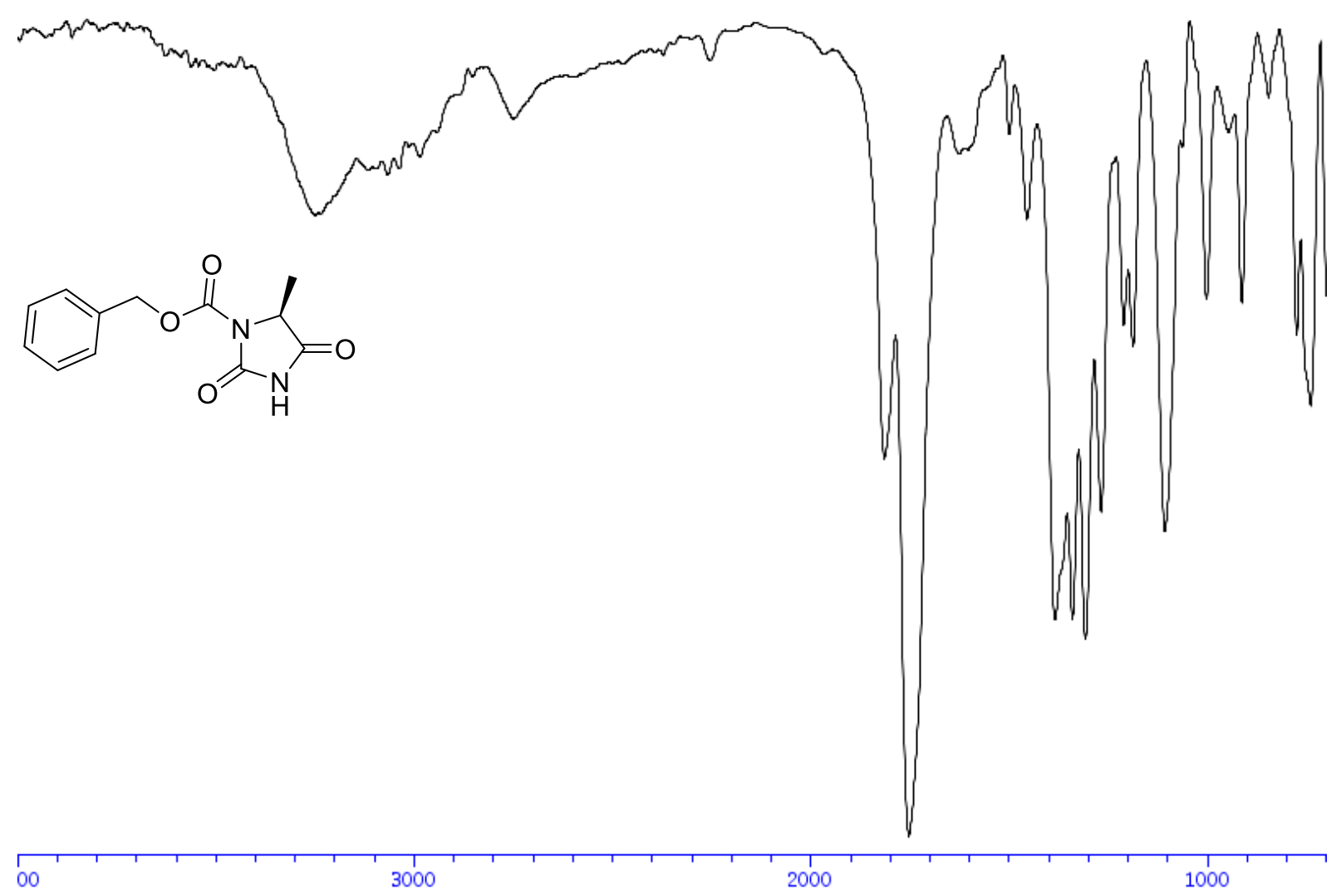

HPLC of compound $\mathbf{8 b}$

Chiralpak ID 85:15 Hexane/iPrOH, $1.0 \mathrm{~mL} / \mathrm{min}, 60 \mathrm{~min}$.

Signal 3: DAD1 C, Sig=214,4 Ref $=360,100$

Peak RetTime Type Width Area Height Area

$\begin{array}{llll}\# & {[\mathrm{~min}]} & \mathrm{min}] & {[\mathrm{mAU} * \mathrm{~s}]}\end{array}$

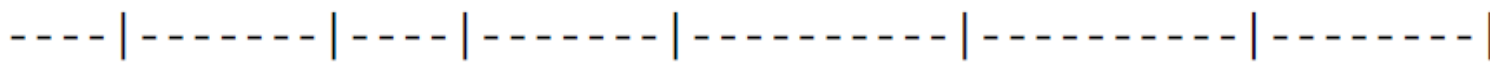

$\begin{array}{lllllll}1 & 20.893 & \text { BV } & 0.6697 & 4287.84912 & 91.66563 & 1.9051\end{array}$

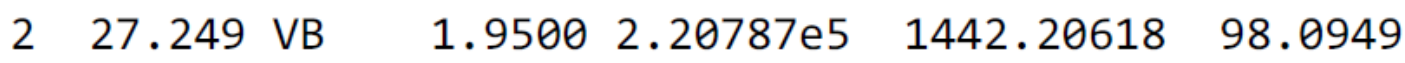

Totals :

2.25075 e5 1533.87180 


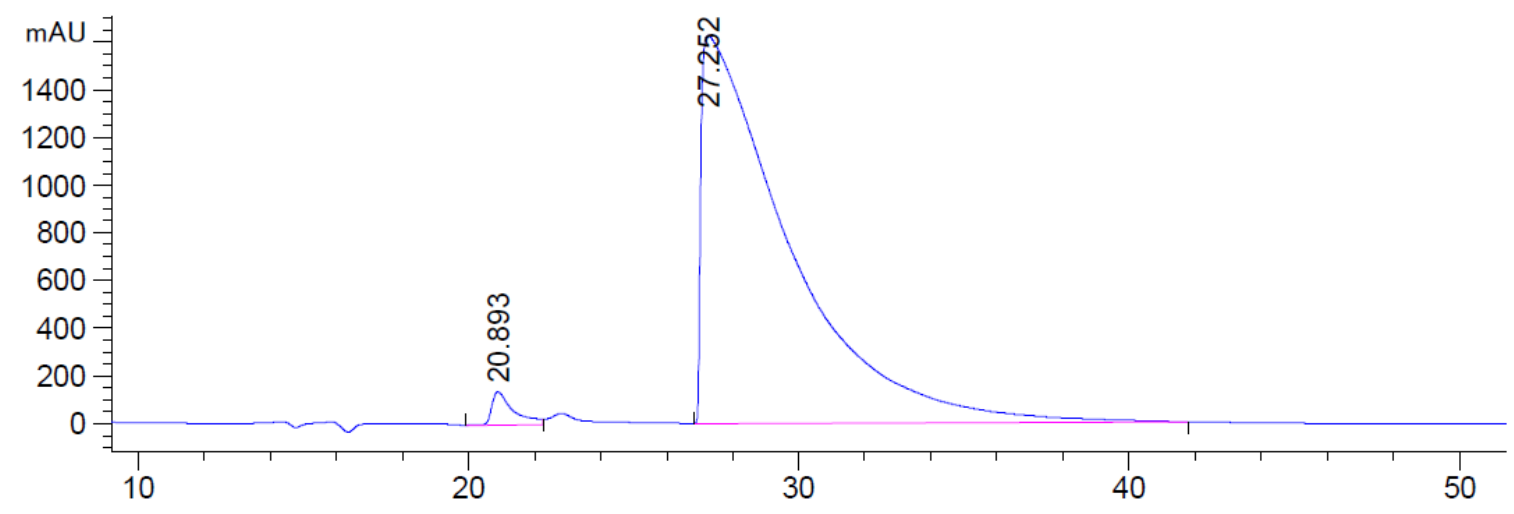

HPLC of racemic compound $\mathbf{8 b}$

Chiralpak ID 85:15 Hexane/iPrOH, $1.0 \mathrm{~mL} / \mathrm{min}, 60 \mathrm{~min}$.

Signal 3: DAD1 C, Sig=214, 4 Ref $=360,100$

Peak RetTime Type Width Area Height Area

\# [min] $[\mathrm{min}] \quad[\mathrm{mAU} * \mathrm{~s}] \quad[\mathrm{mAU}] \quad \%$

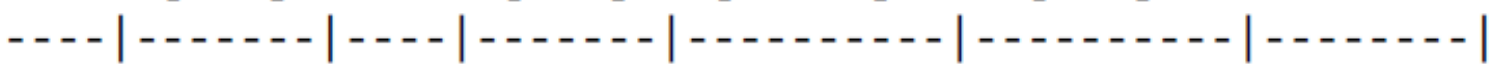

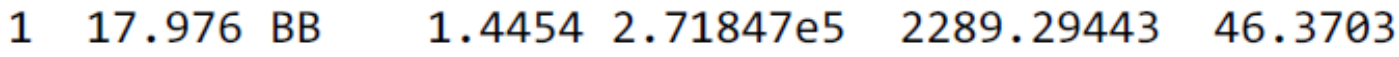

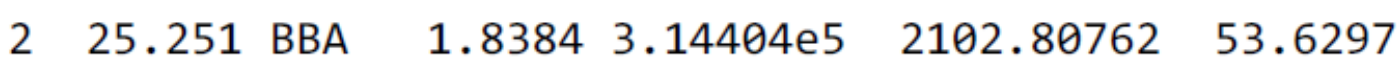

Totals : $\quad 5.86251 \mathrm{e} 5 \quad 4392.10205$

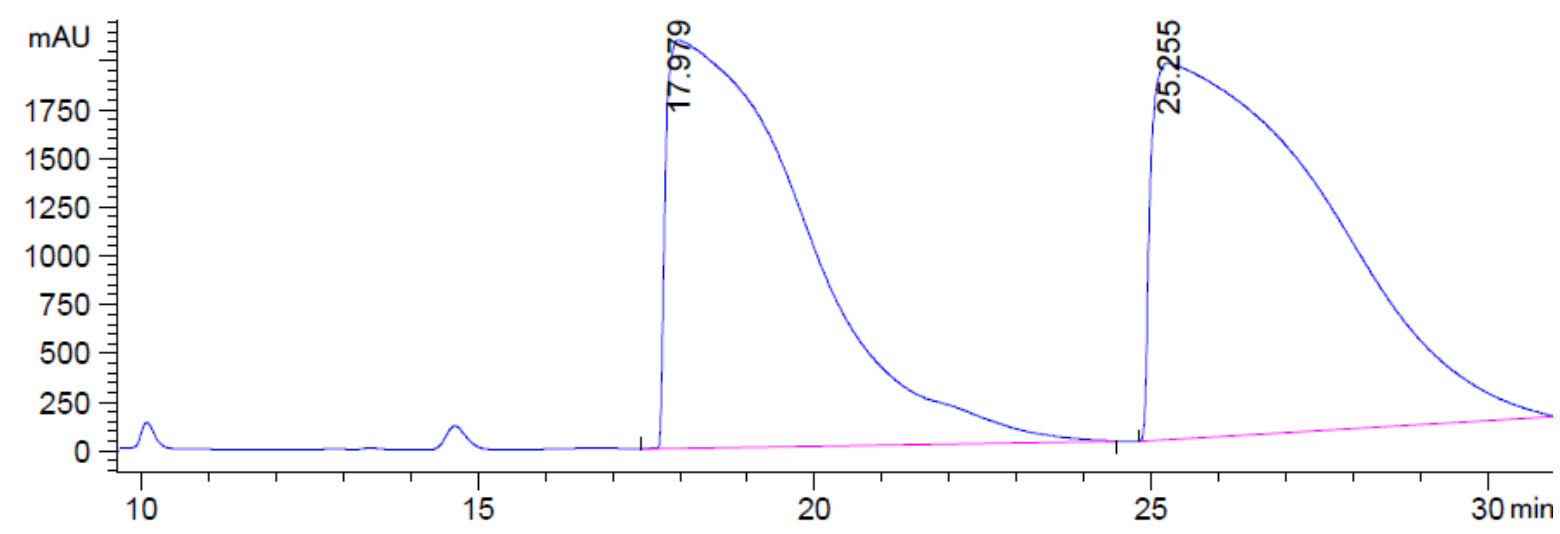


${ }^{1} \mathbf{H}-\mathbf{N M R}\left(400 \mathrm{MHz}, \mathrm{CDCl}_{3}\right)$ of compound $\mathbf{8 c}$

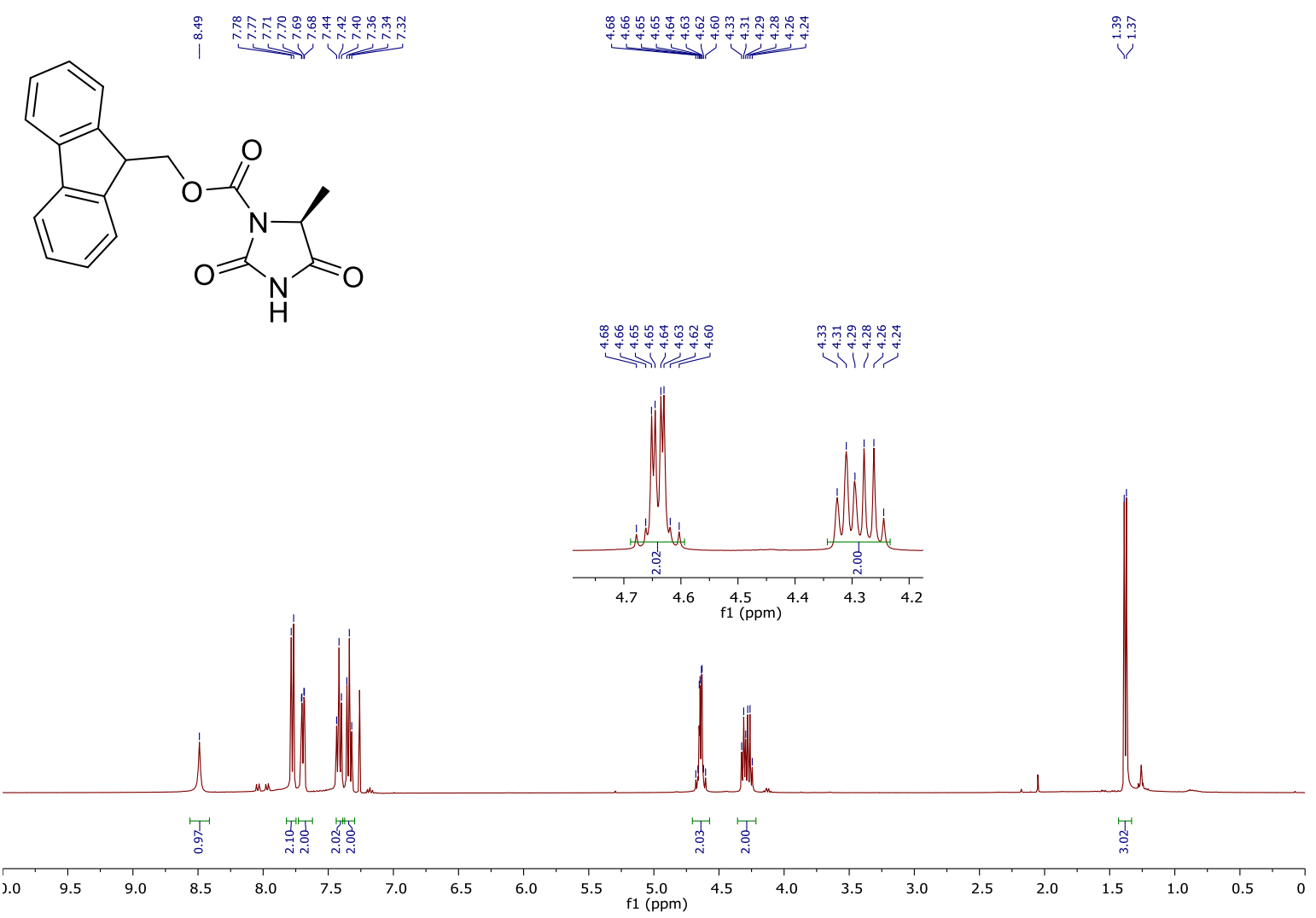

${ }^{13} \mathbf{C}$-NMR $\left(100 \mathrm{MHz}, \mathrm{CDCl}_{3}\right)$ of compound $\mathbf{8 c}$

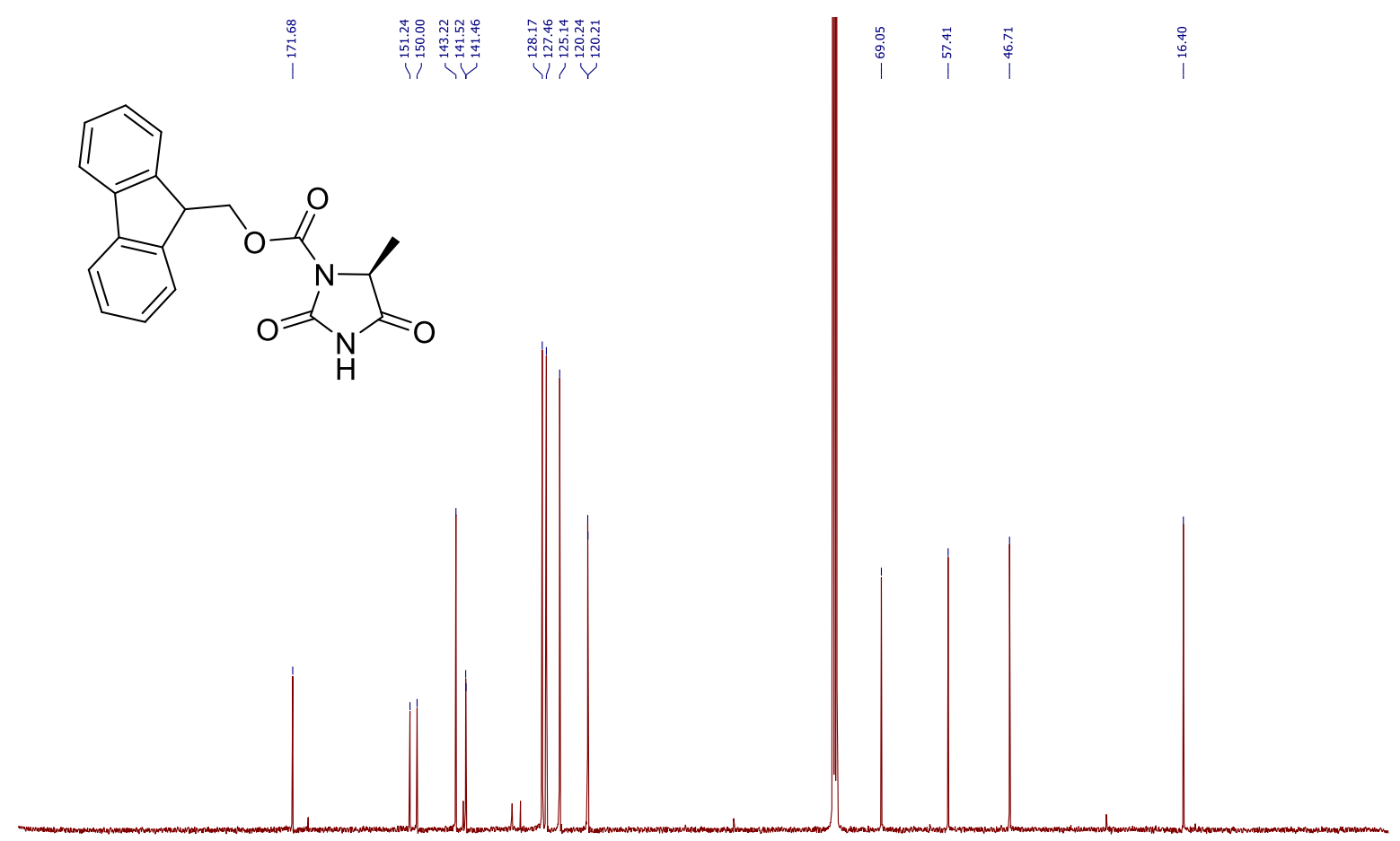

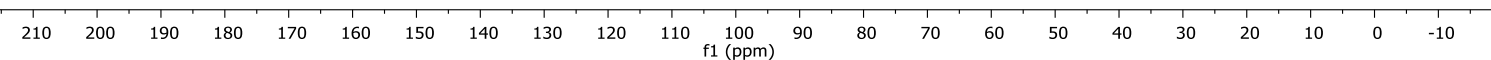


IR of compound $\mathbf{8 c}$

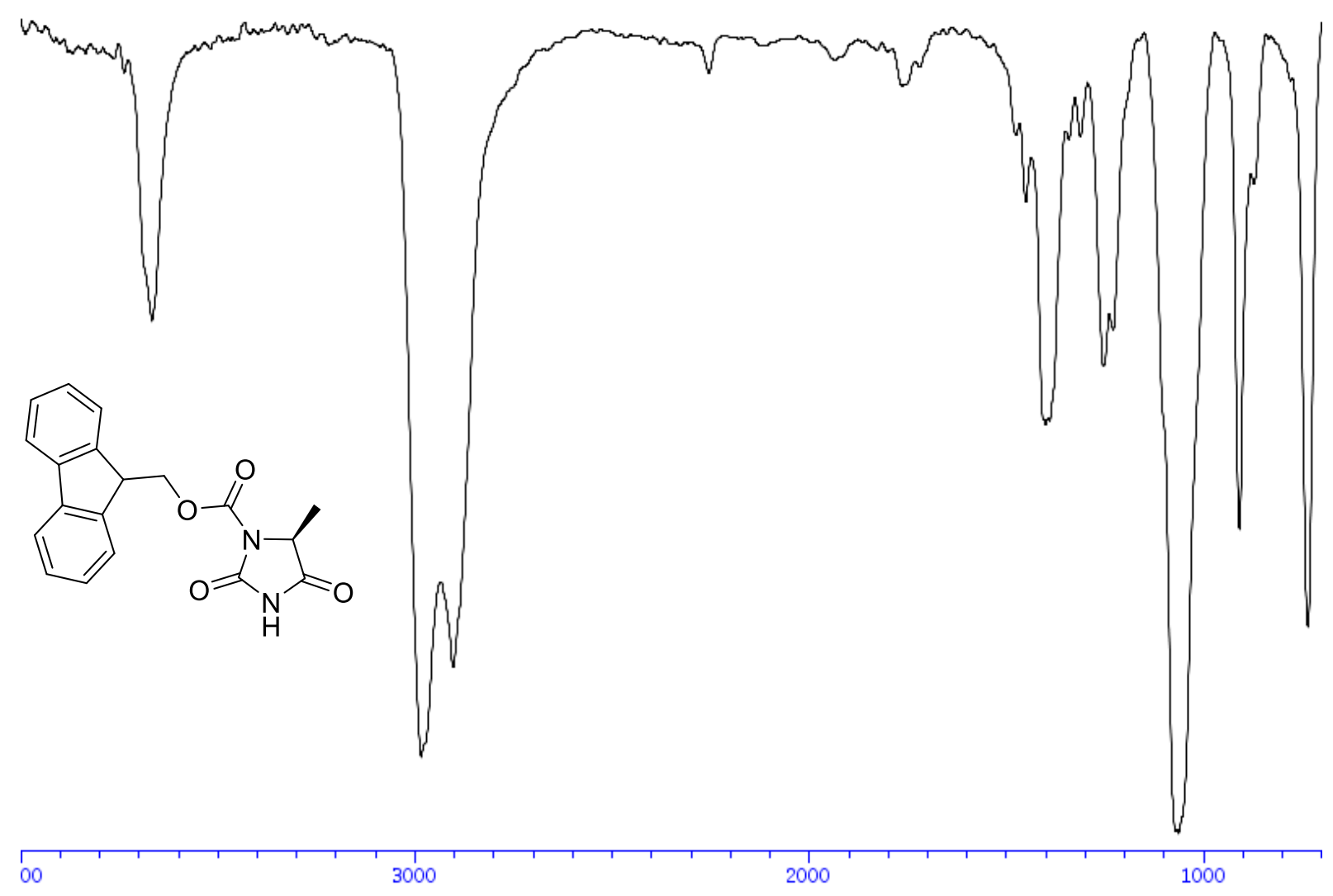


${ }^{\mathbf{1}} \mathbf{H}-\mathbf{N M R}\left(400 \mathrm{MHz}, \mathrm{CDCl}_{3}\right)$ crude of compound $\mathbf{8 d}$<smiles>CC(=O)N1C(=O)NC(=O)C1C</smiles>
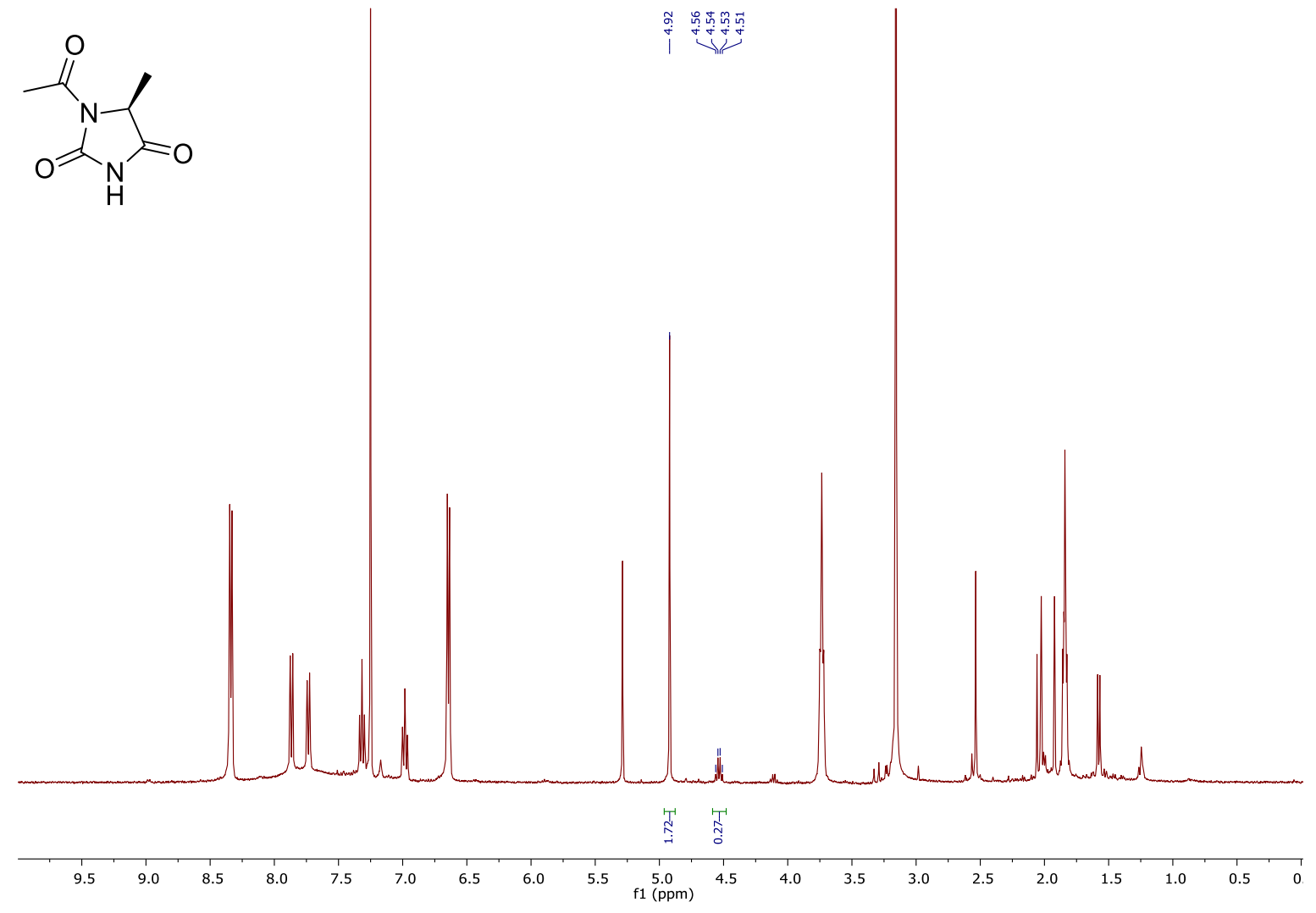

${ }^{1} \mathbf{H}-\mathbf{N M R}$ (400 MHz, $\mathrm{CDCl}_{3}$ ) crude of compound $\mathbf{8 e}$

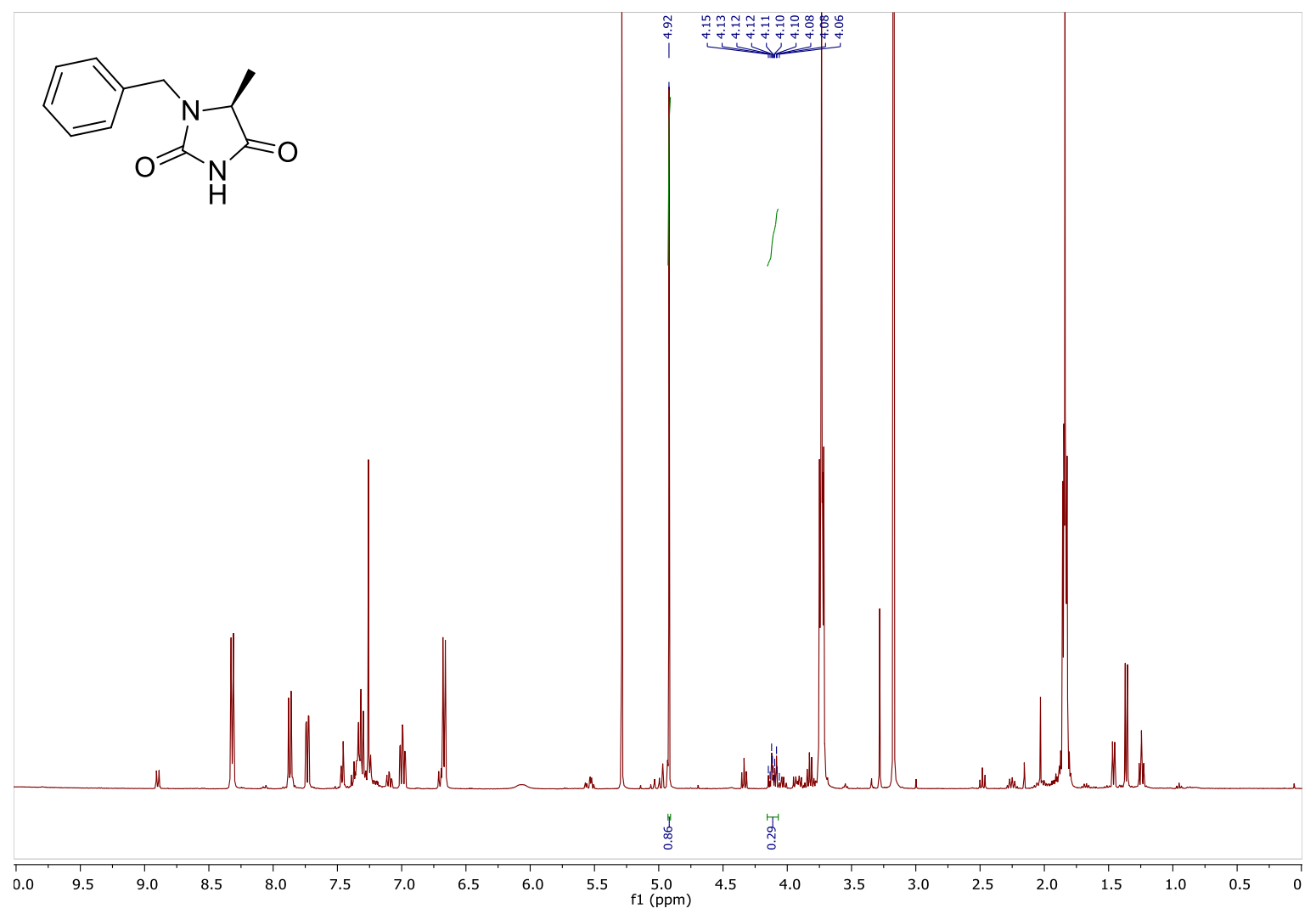


${ }^{\mathbf{1}} \mathbf{H}$-NMR $\left(400 \mathrm{MHz}, \mathrm{CDCl}_{3}\right.$ ) of compound $\mathbf{8 g}$

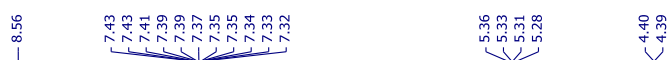

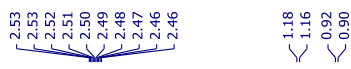<smiles>CC(C)C1C(=O)NC(=O)N1C(=O)OCc1ccccc1</smiles>

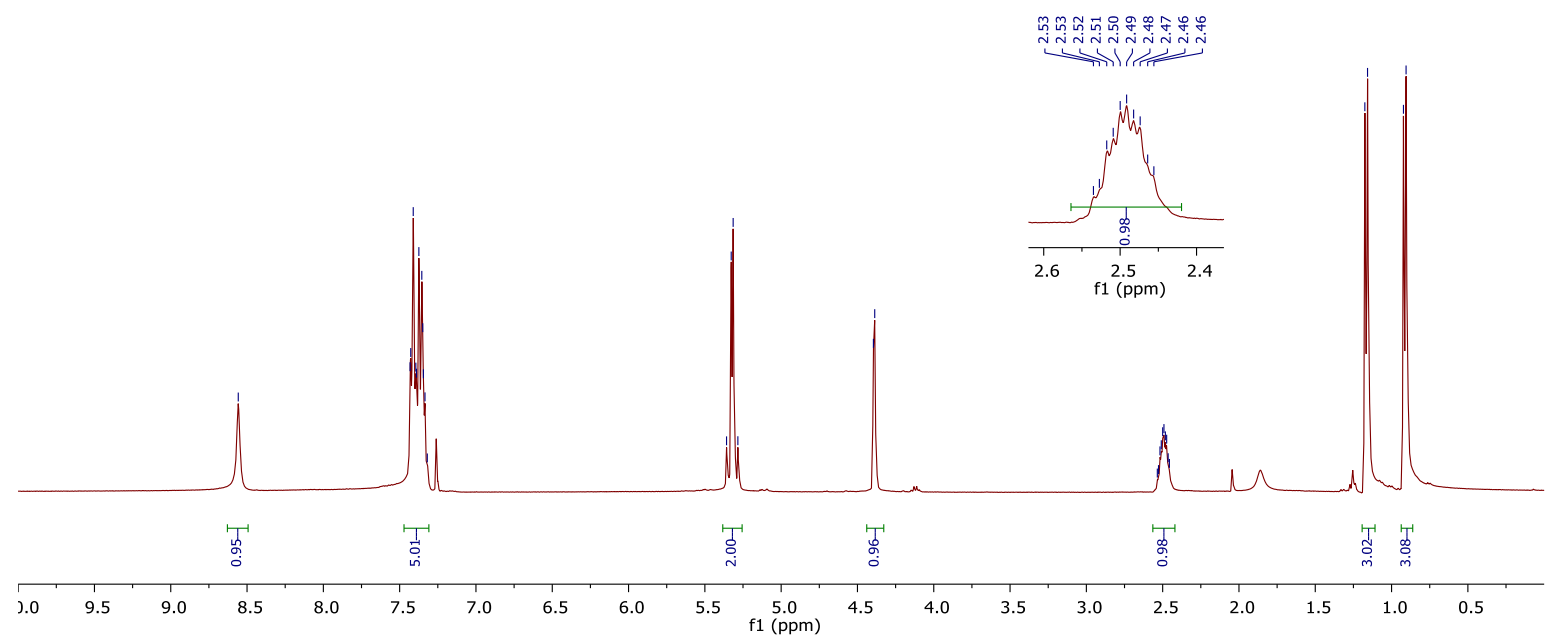

${ }^{13}$ C-NMR (100 MHz, $\left.\mathrm{CDCl}_{3}\right)$ of compound $\mathbf{8 g}$

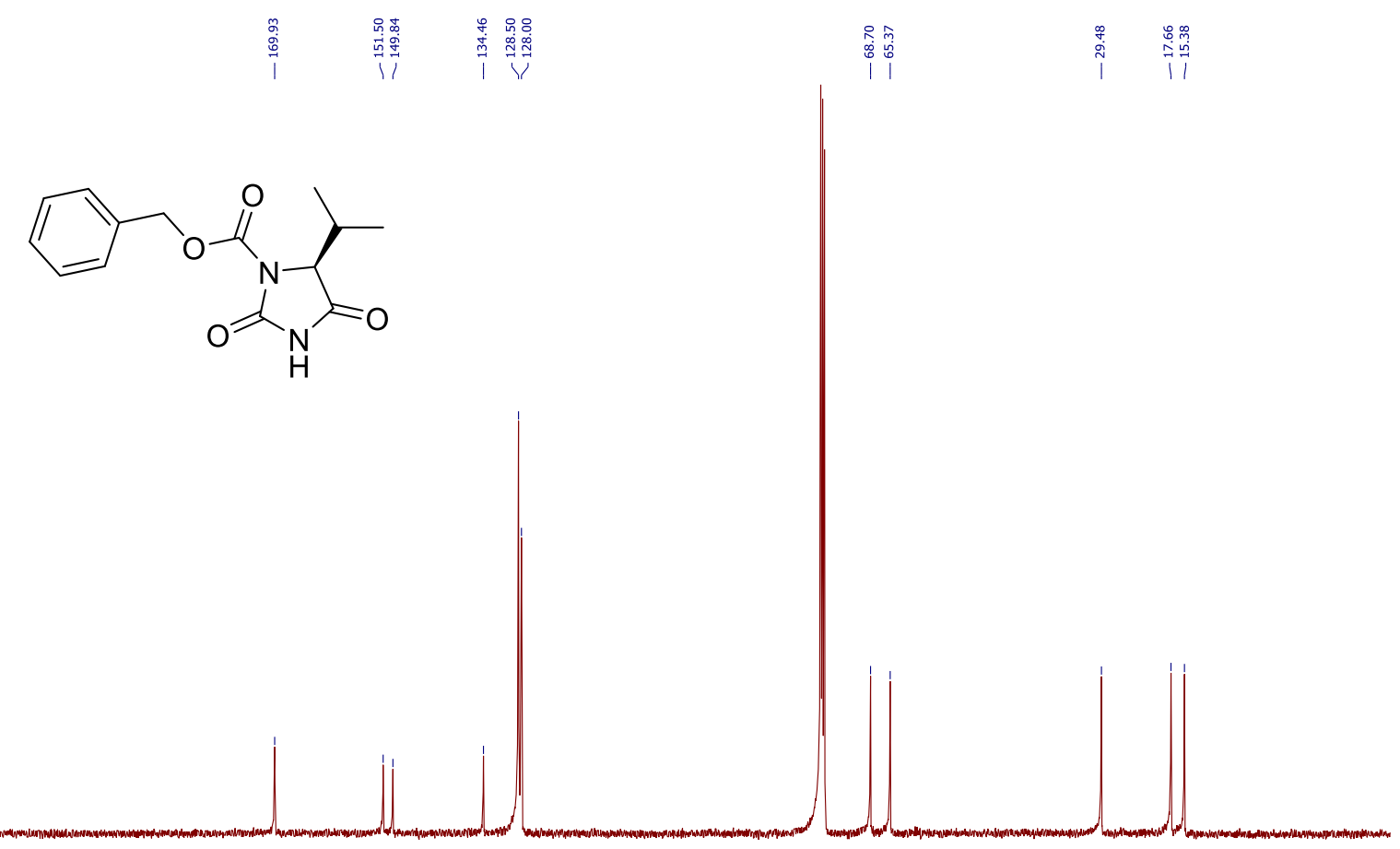

$\begin{array}{llllllllllllllllllllllllll}210 & 200 & 190 & 180 & 170 & 160 & 150 & 140 & 130 & 120 & 110 & 100 & 90 & 80 & 70 & 60 & 50 & 40 & 30 & 20 & 10 & 0 & -10\end{array}$ 


\section{IR of compound $\mathbf{8 g}$}

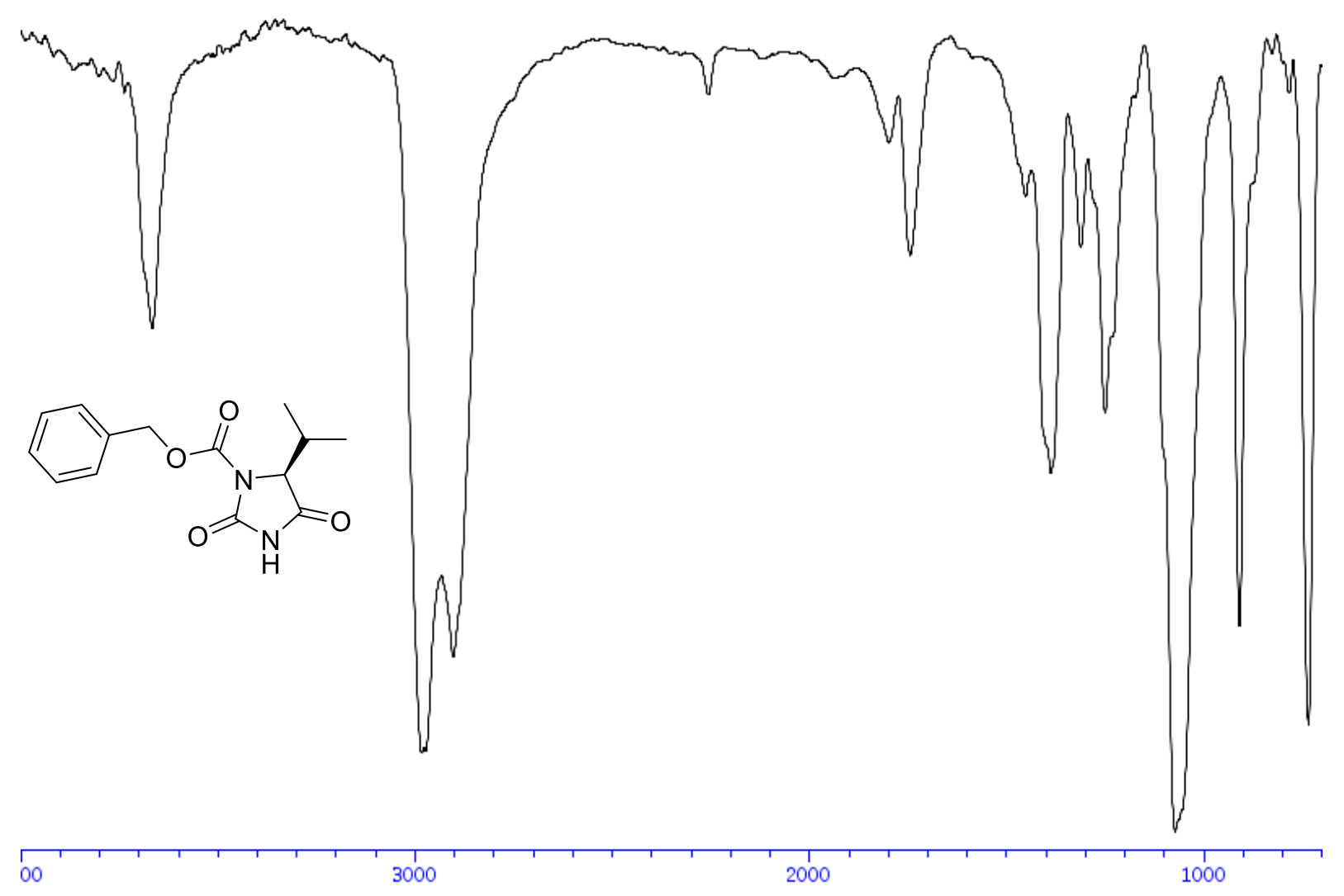


${ }^{\mathbf{1}} \mathbf{H}-\mathbf{N M R}\left(400 \mathrm{MHz}, \mathrm{CDCl}_{3}\right.$ ) of compound $\mathbf{8 h}$

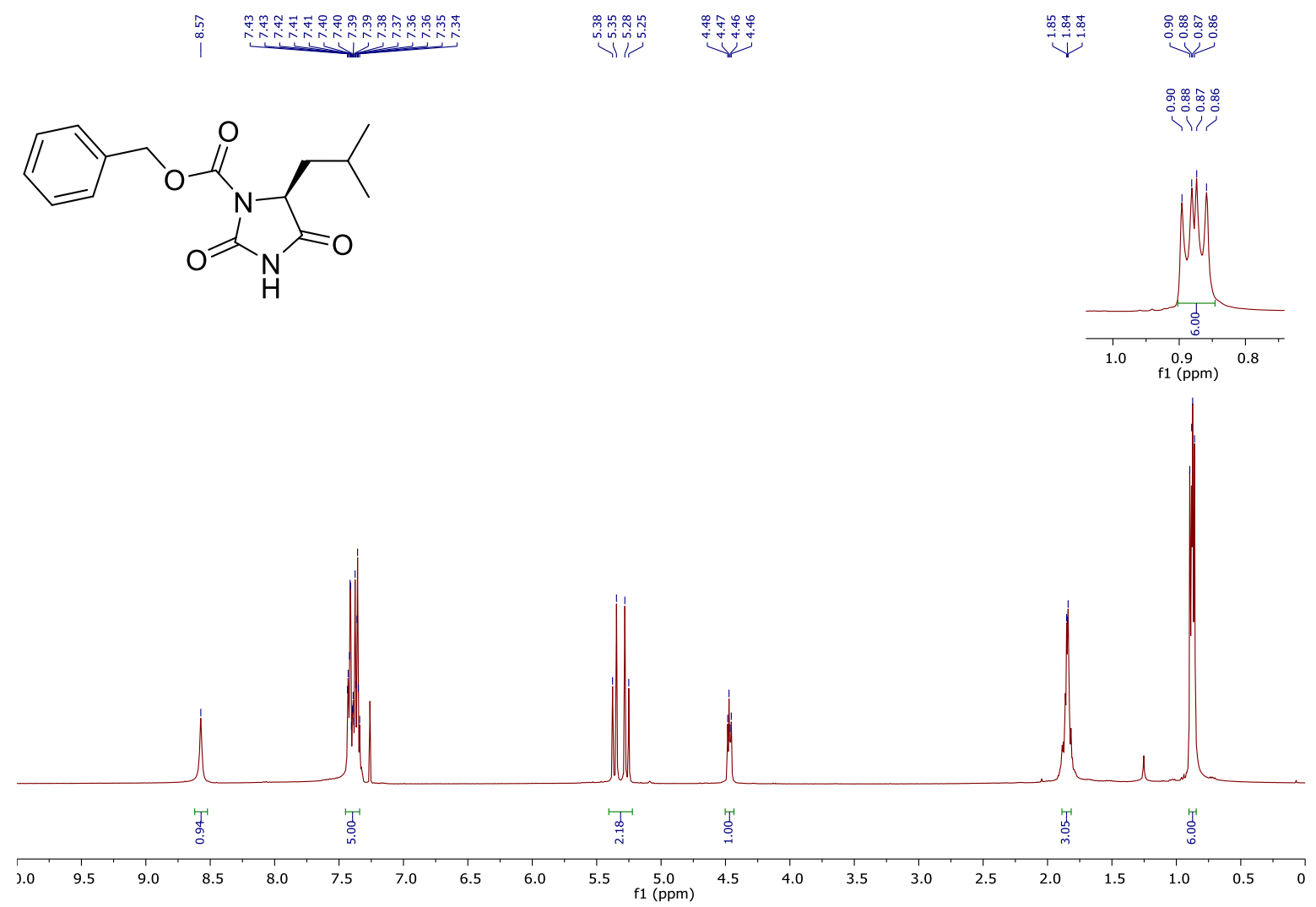

${ }^{13} \mathbf{C}-\mathrm{NMR}\left(100 \mathrm{MHz}, \mathrm{CDCl}_{3}\right)$ of compound $\mathbf{8 h}$

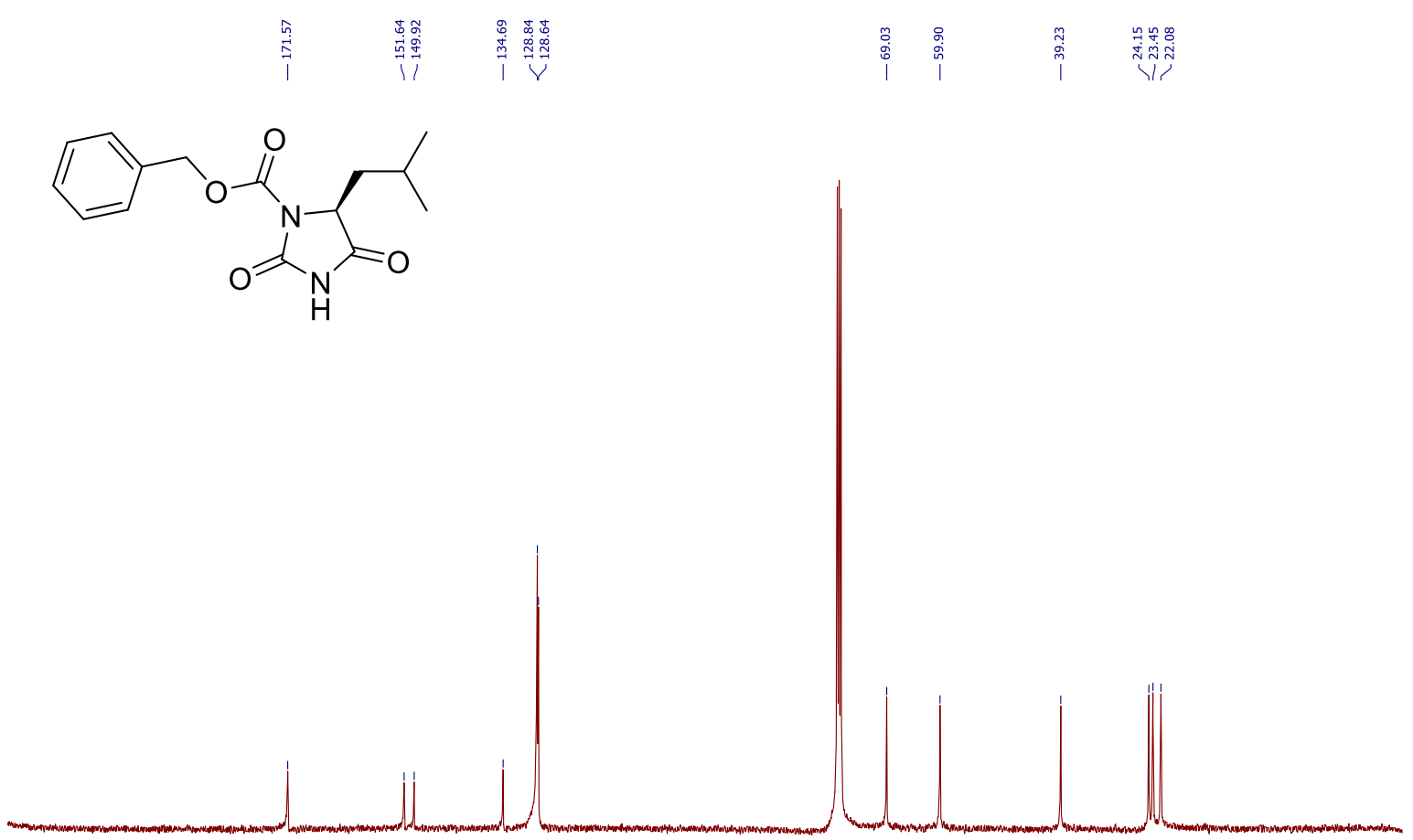

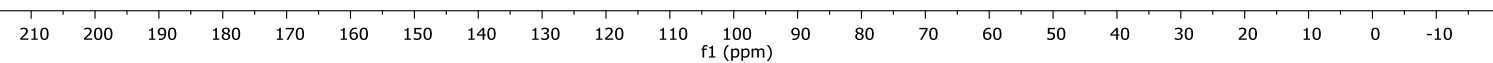


IR of compound $\mathbf{8 h}$
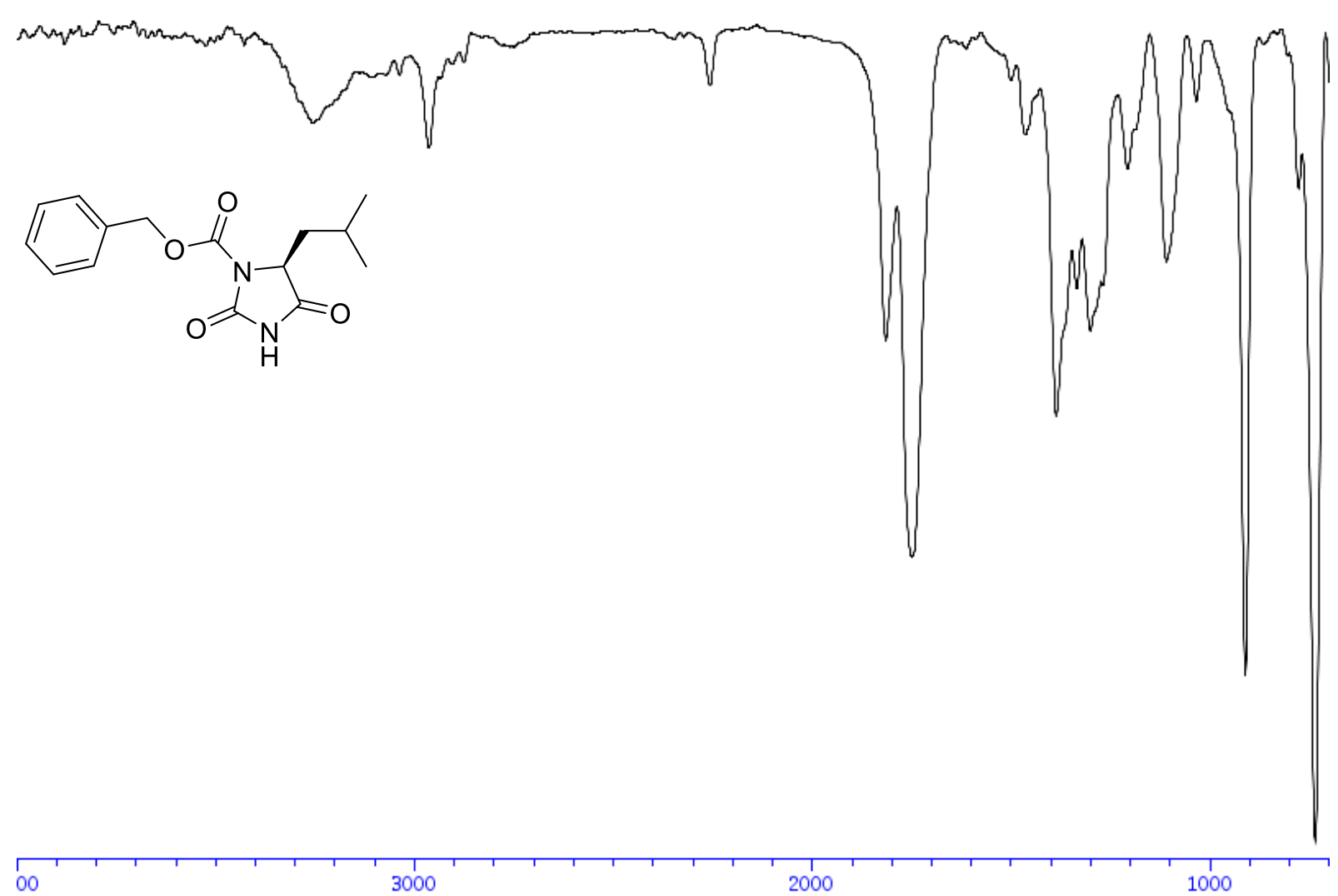
${ }^{\mathbf{1}} \mathbf{H}$-NMR $\left(400 \mathrm{MHz}, \mathrm{CDCl}_{3}\right.$ ) of compound $\mathbf{8 i}$

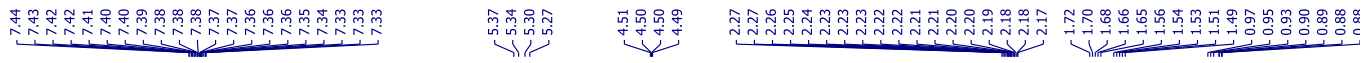<smiles>CCC(C)[C@H]1C(=O)NC(=O)N1C(=O)OCc1ccccc1</smiles>
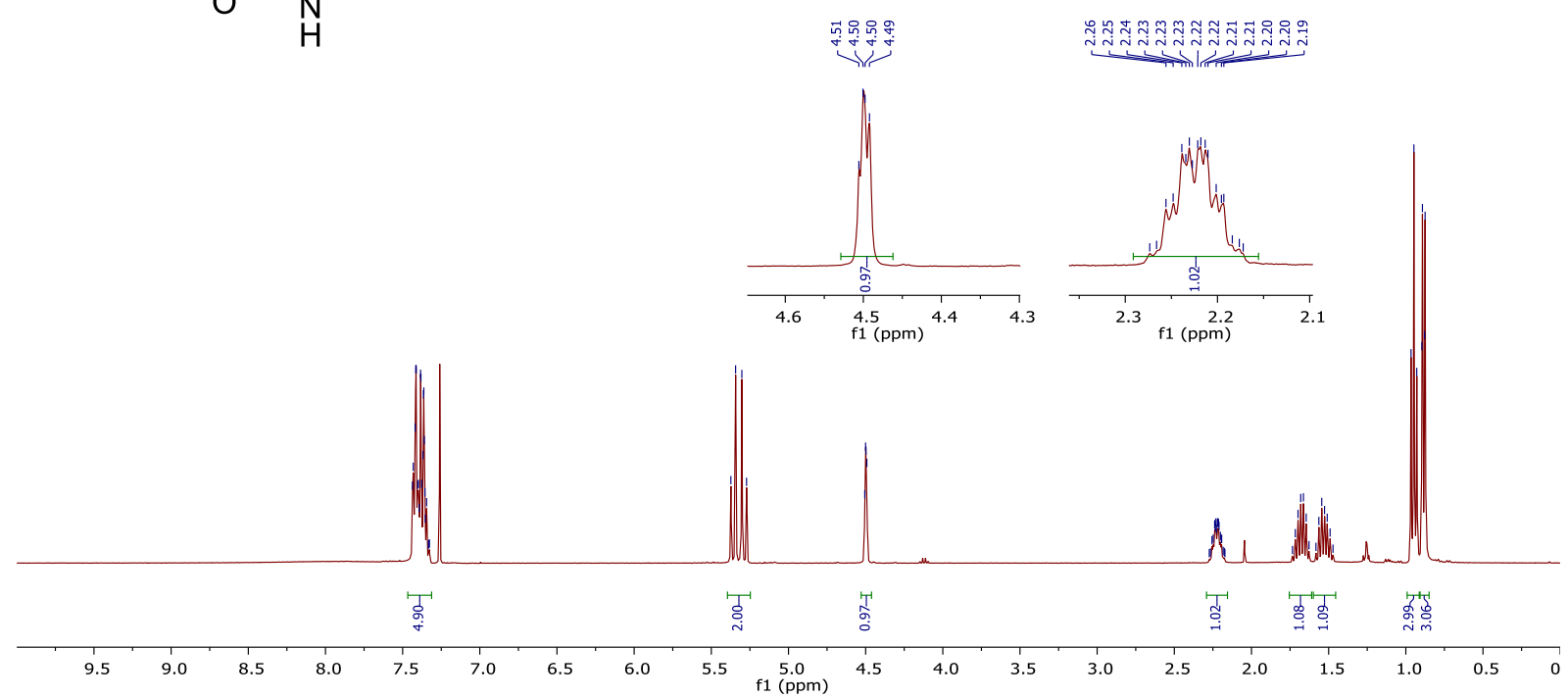

${ }^{13} \mathbf{C}$-NMR $\left(100 \mathrm{MHz}, \mathrm{CDCl}_{3}\right)$ of compound $\mathbf{8 i}$<smiles>CCC(C)C1C(=O)NC(=O)N1C(=O)OCc1ccccc1</smiles>

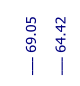

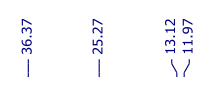

$\begin{array}{lllllllllll}210 & 200 & 190 & 180 & 170 & 160 & 150 & 140 & 130 & 120 & 110 \\ \mathrm{f} 1(\mathrm{ppm})\end{array}$ 
IR of compound $\mathbf{8 i}$

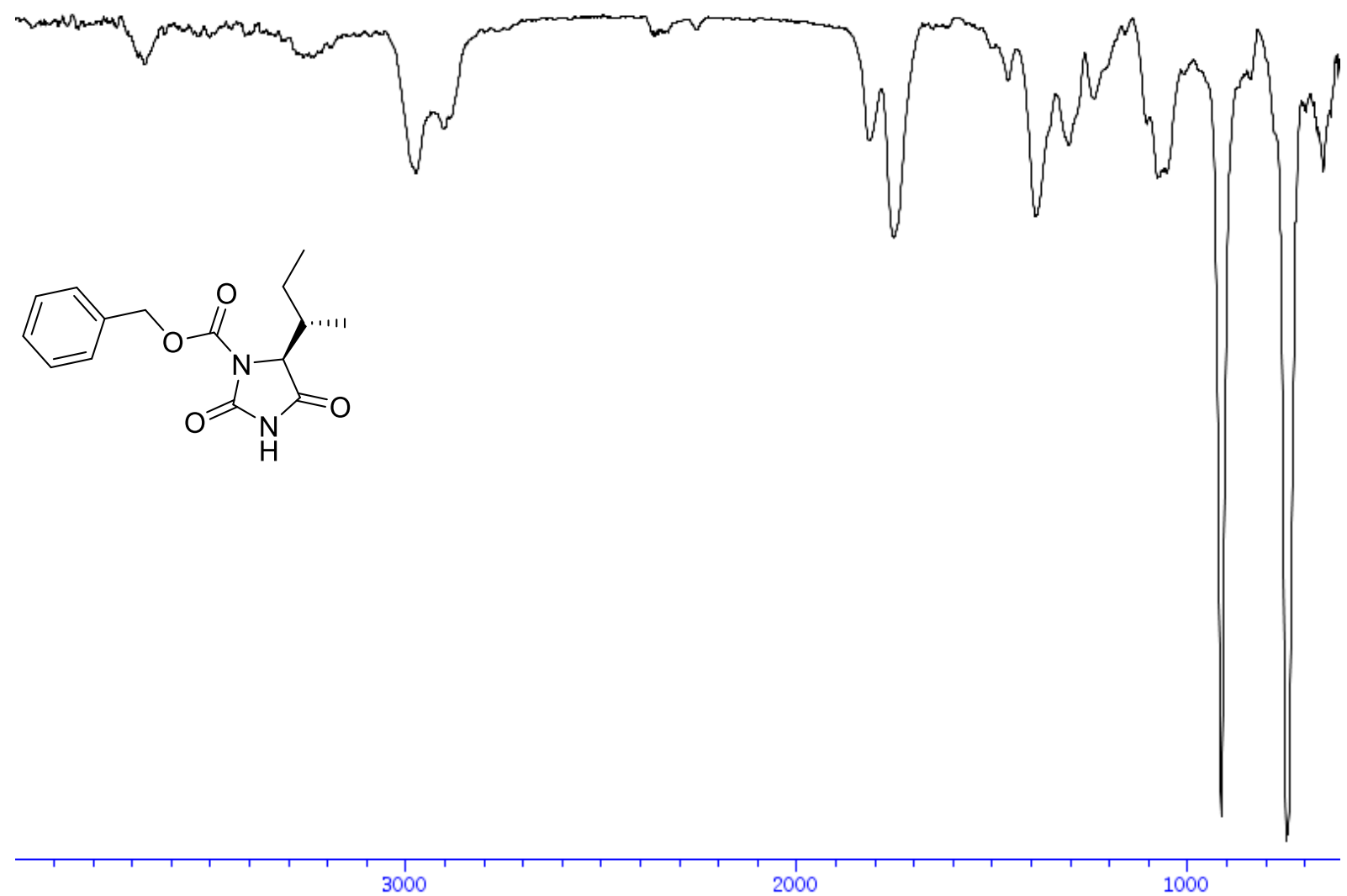


${ }^{\mathbf{1}} \mathbf{H}-\mathbf{N M R}\left(400 \mathrm{MHz}, \mathrm{CDCl}_{3}\right.$ ) of compound $\mathbf{8 j}$

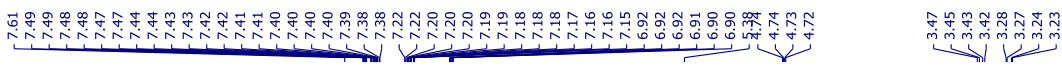<smiles>O=C1NC(=O)N(C(=O)OCc2ccccc2)C1Cc1ccccc1</smiles>

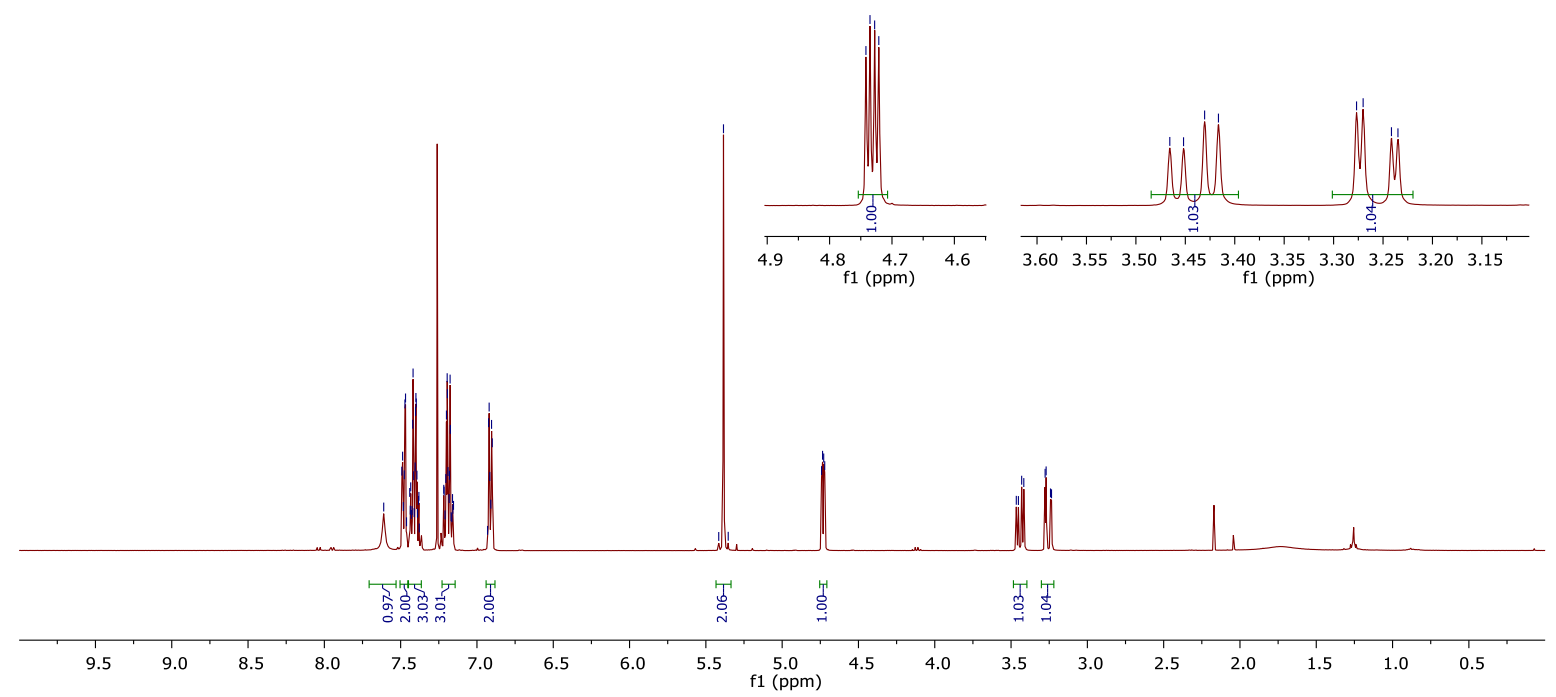

${ }^{13}$ C-NMR (100 MHz, $\left.\mathrm{CDCl}_{3}\right)$ of compound $\mathbf{8 j}$

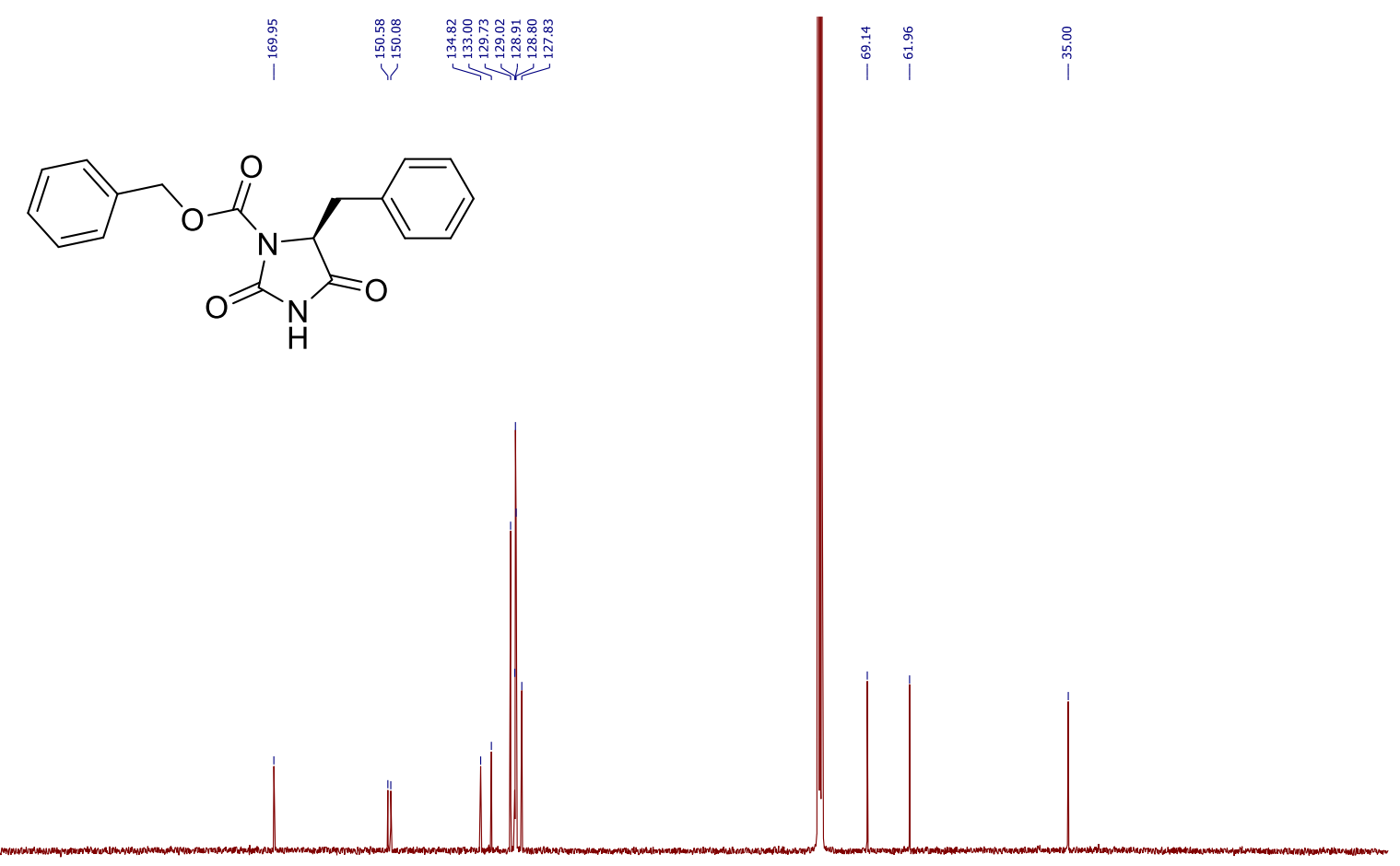

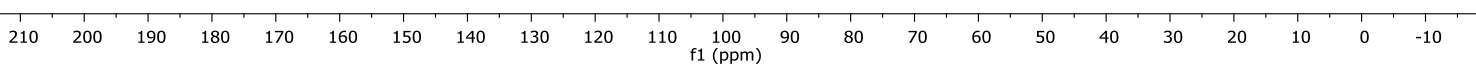




\section{IR of compound $\mathbf{8 j}$}

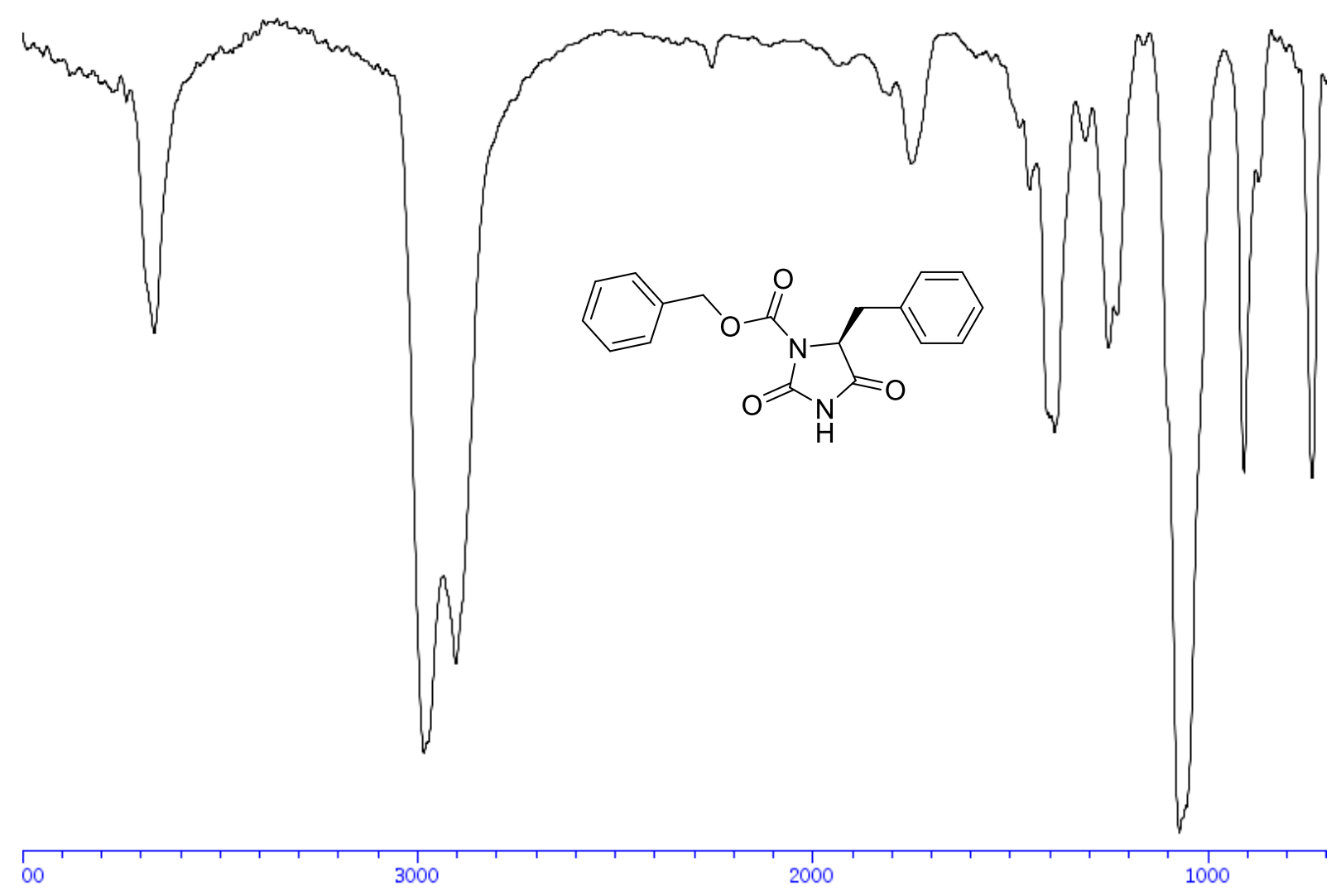


${ }^{\mathbf{1}} \mathbf{H}-\mathbf{N M R}\left(400 \mathrm{MHz}, \mathrm{CDCl}_{3}\right.$ ) of compound $\mathbf{8 k}$

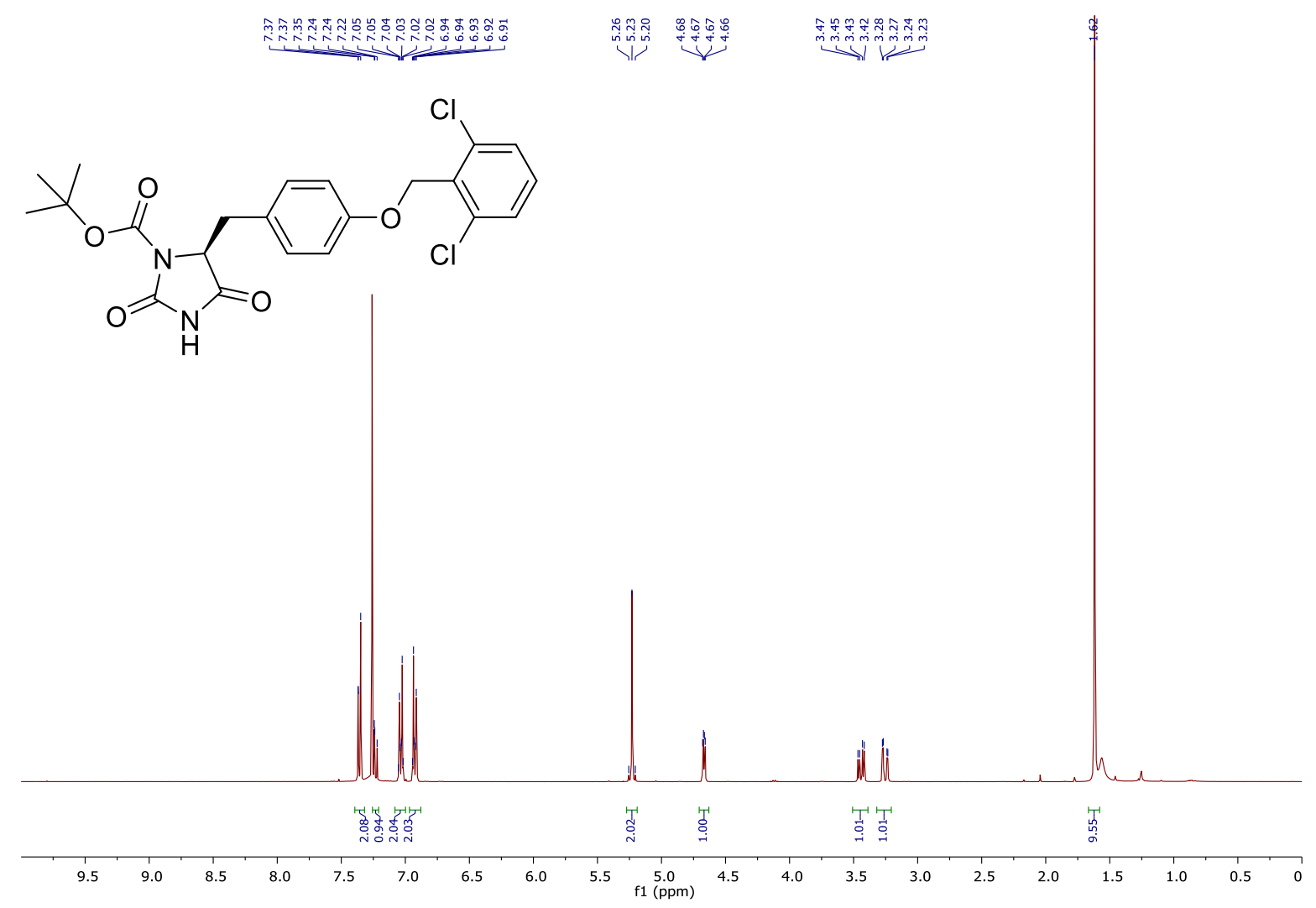

${ }^{13} \mathbf{C}-\mathbf{N M R}\left(100 \mathrm{MHz}, \mathrm{CDCl}_{3}\right)$ of compound $\mathbf{8 k}$

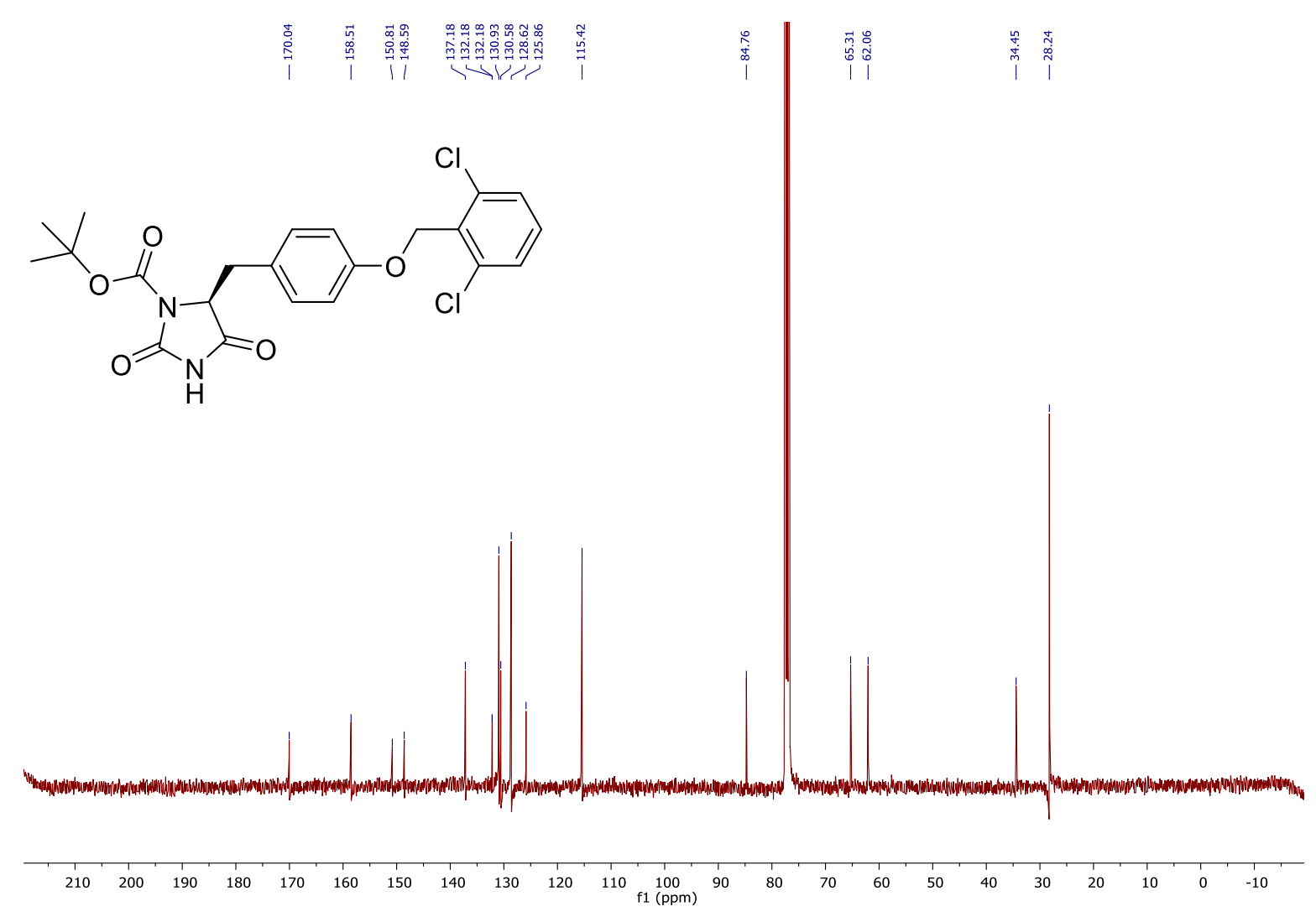


IR of compound $\mathbf{8 k}$

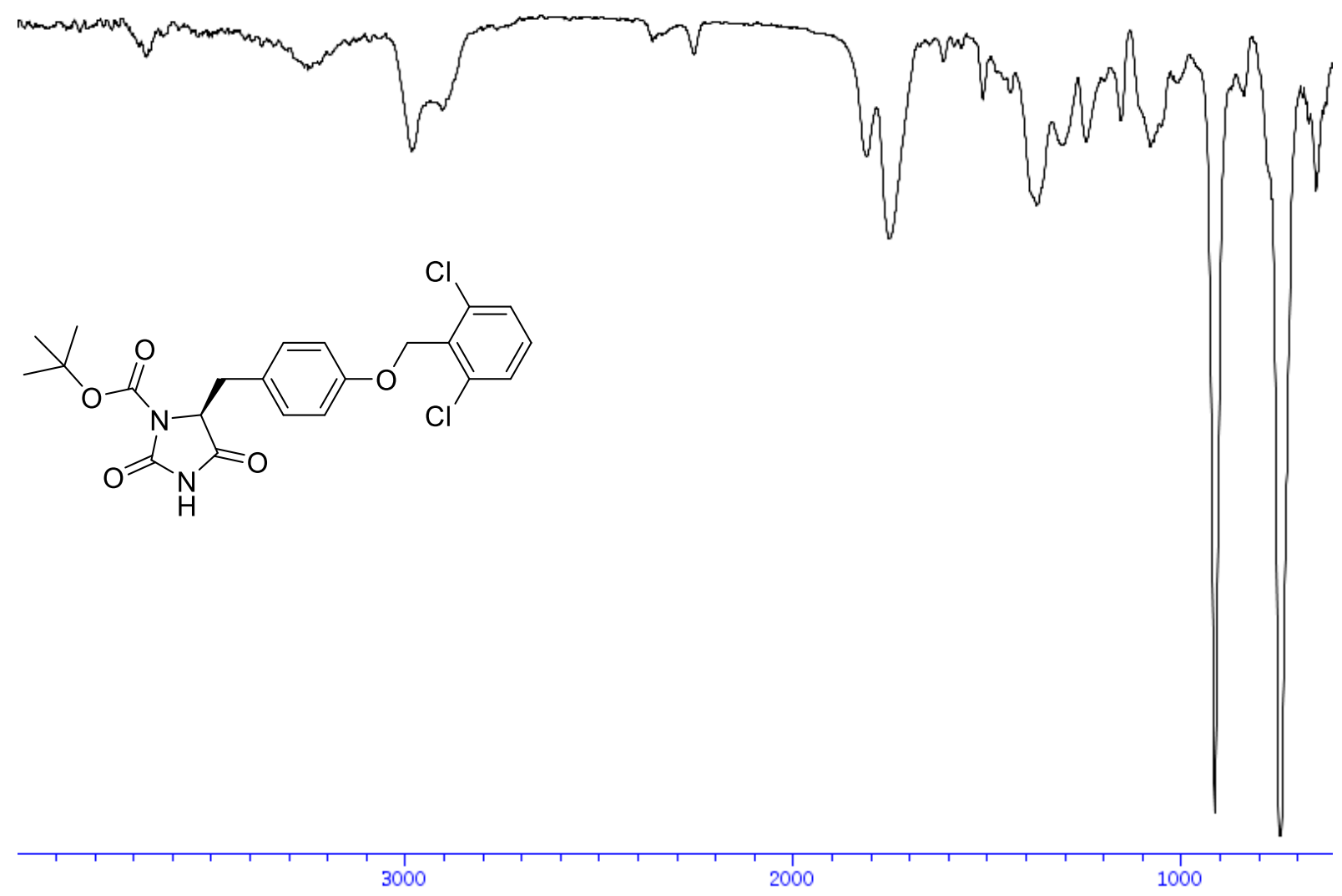


${ }^{\mathbf{1}} \mathbf{H}$-NMR $\left(400 \mathrm{MHz}, \mathrm{CDCl}_{3}\right.$ ) of compound $\mathbf{8 1}$

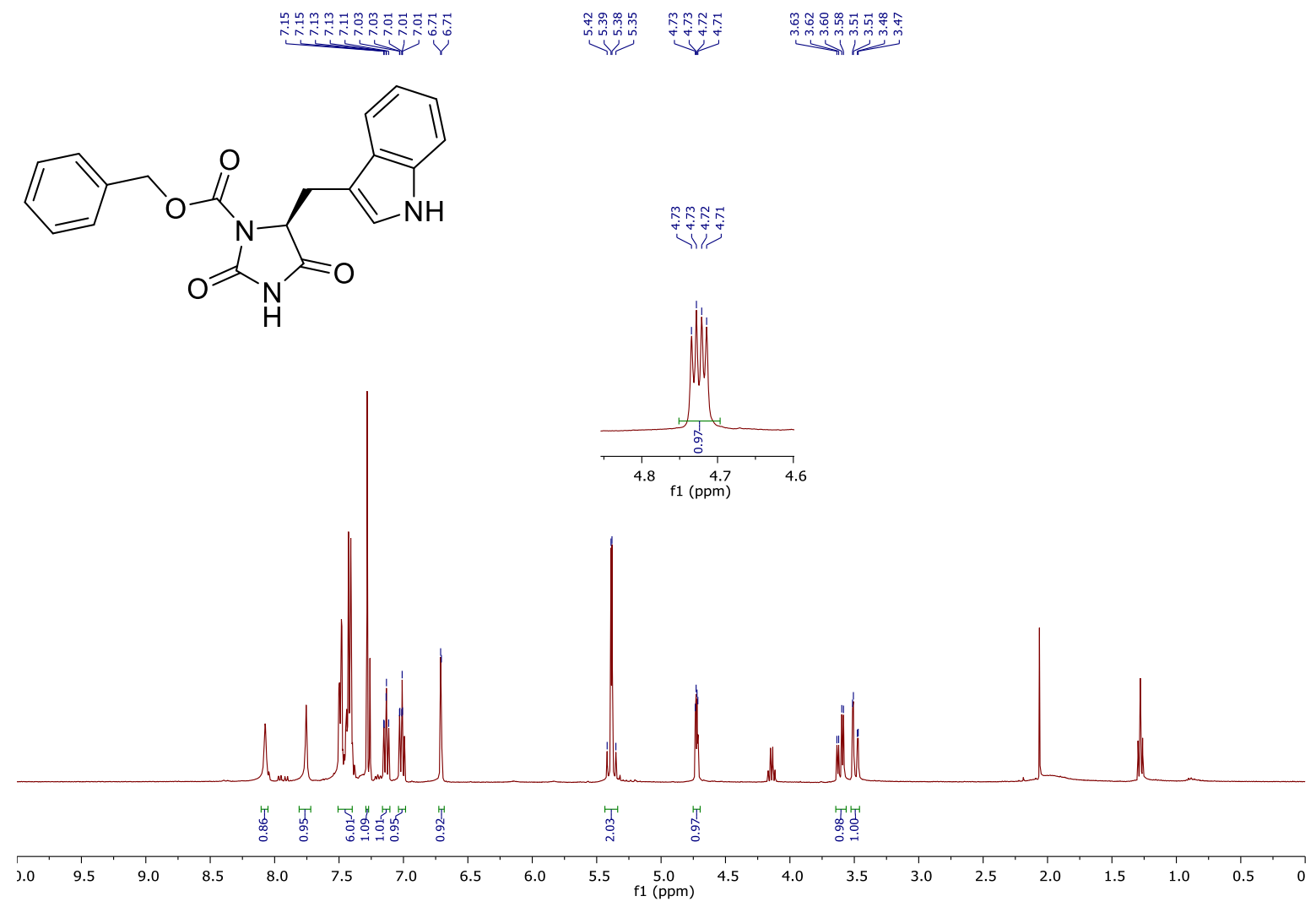

${ }^{13}$ C-NMR $\left(100 \mathrm{MHz}, \mathrm{CDCl}_{3}\right)$ of compound $\mathbf{8 l}$

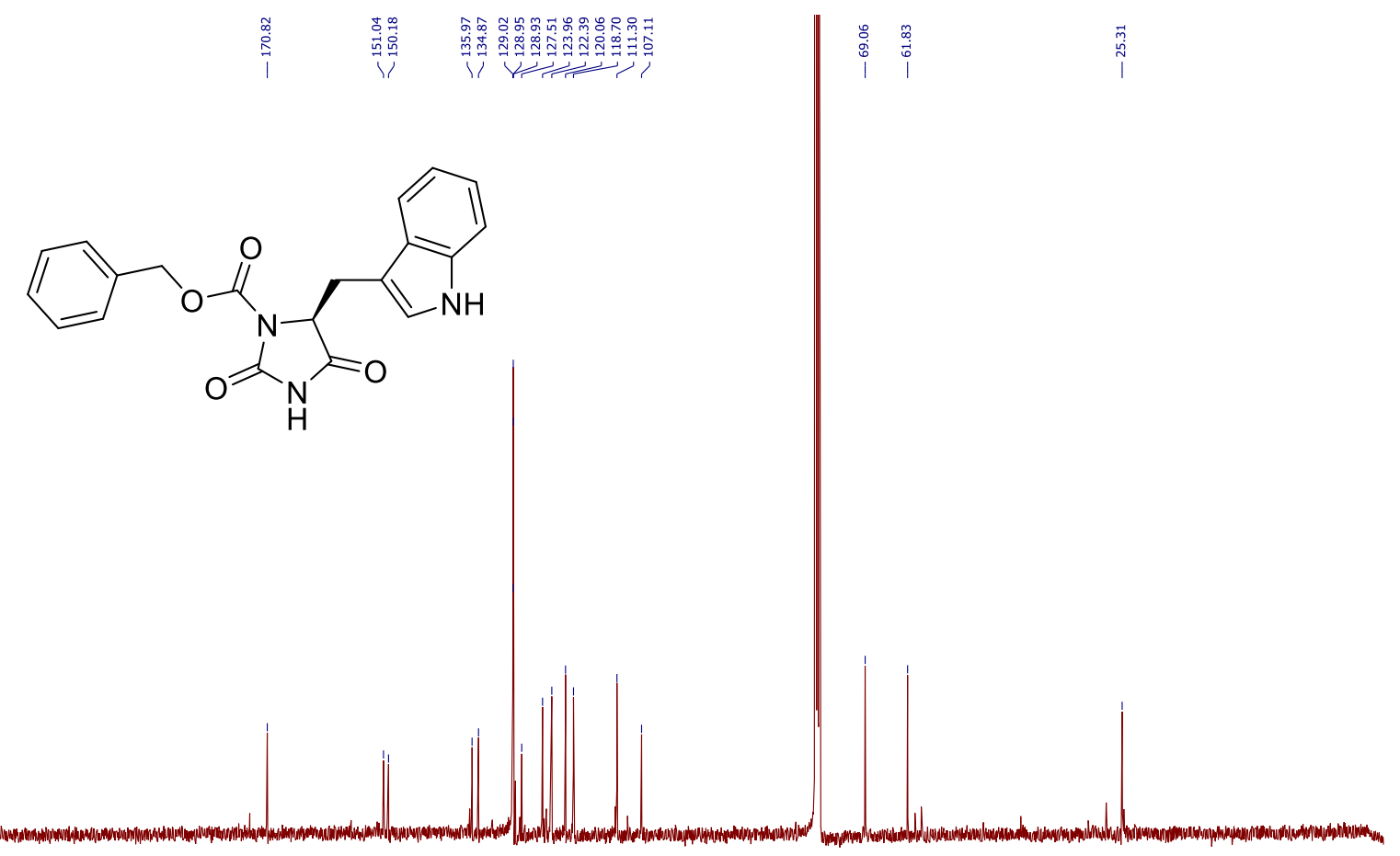

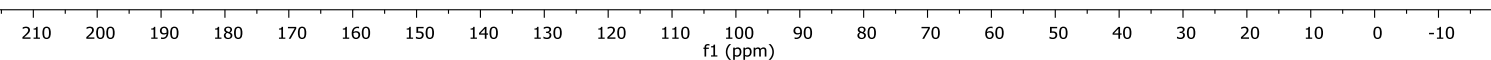


IR of compound $\mathbf{8 1}$

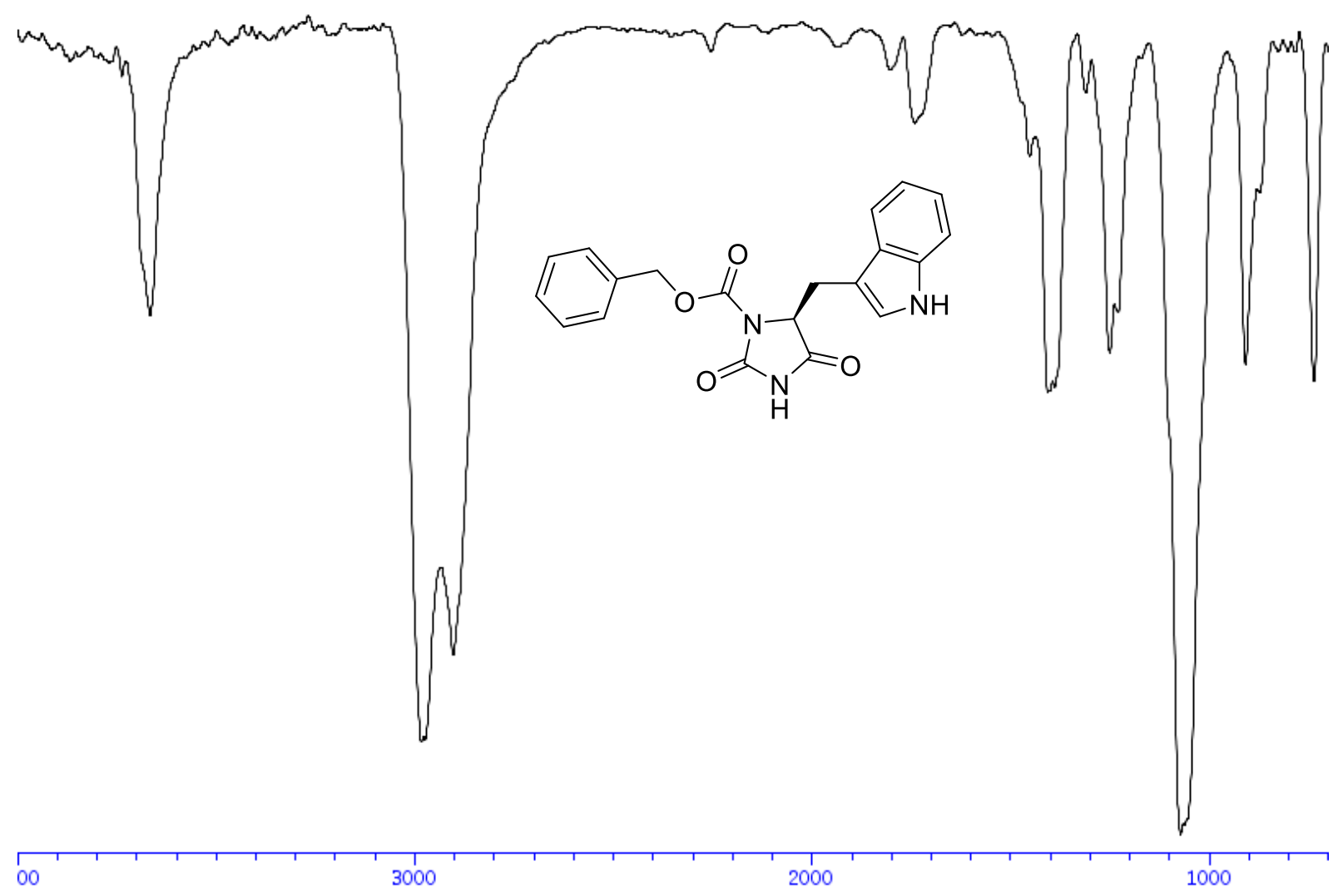


${ }^{\mathbf{1}} \mathbf{H}-\mathbf{N M R}\left(400 \mathrm{MHz}, \mathrm{CDCl}_{3}\right.$ ) of compound $\mathbf{8 m}$

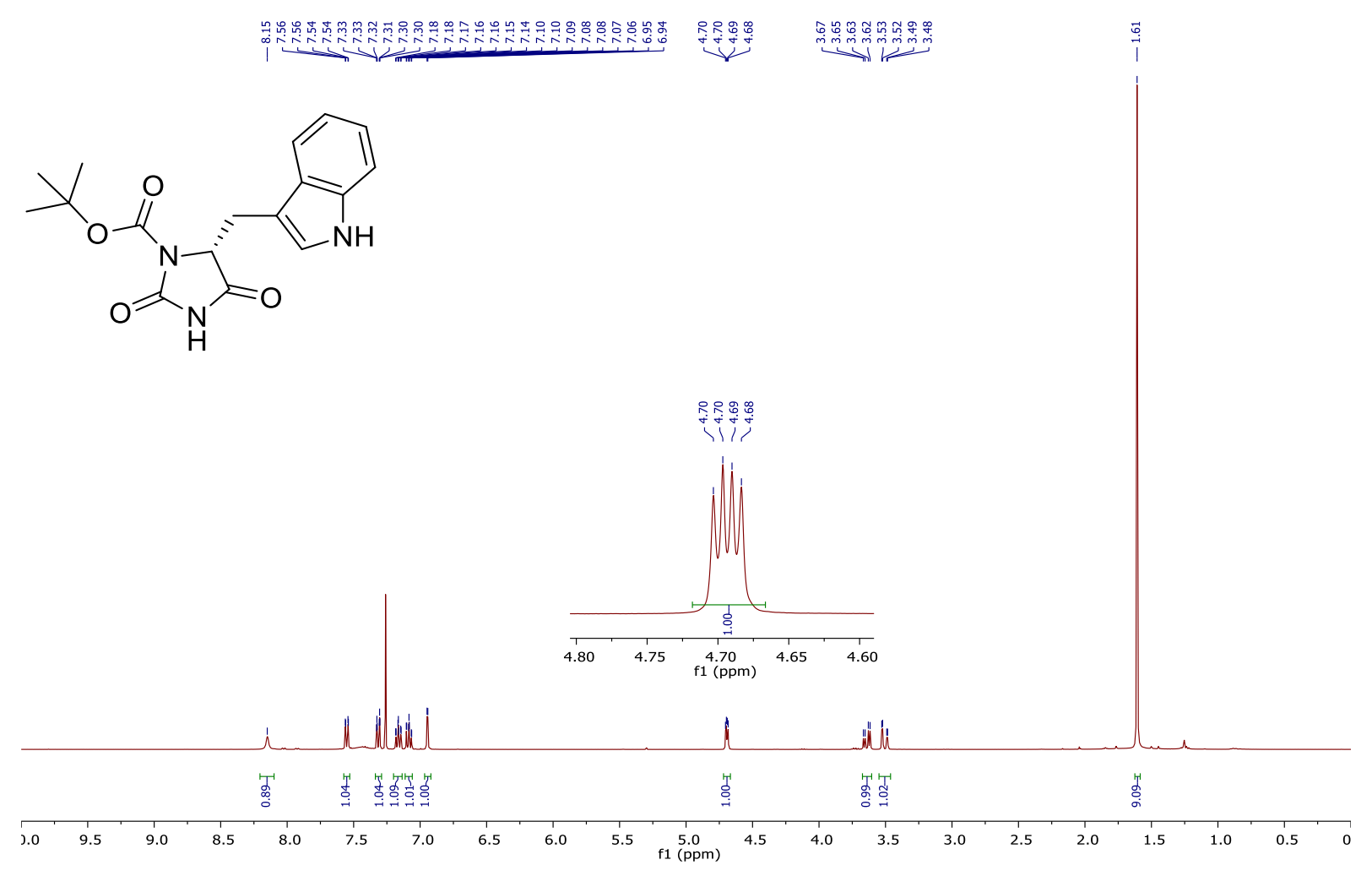

${ }^{13} \mathbf{C}-\mathrm{NMR}\left(100 \mathrm{MHz}, \mathrm{CDCl}_{3}\right)$ of compound $\mathbf{8 m}$

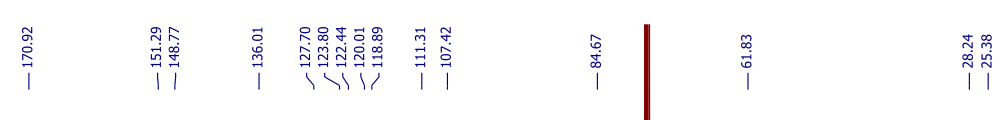<smiles>CC(C)(C)OC(=O)N1C(=O)NC(=O)C1Cc1c[nH]c2ccccc12</smiles>

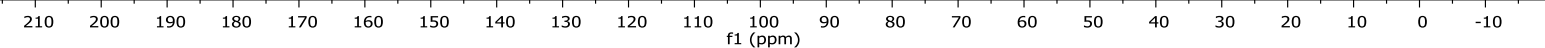


IR of compound $\mathbf{8 m}$

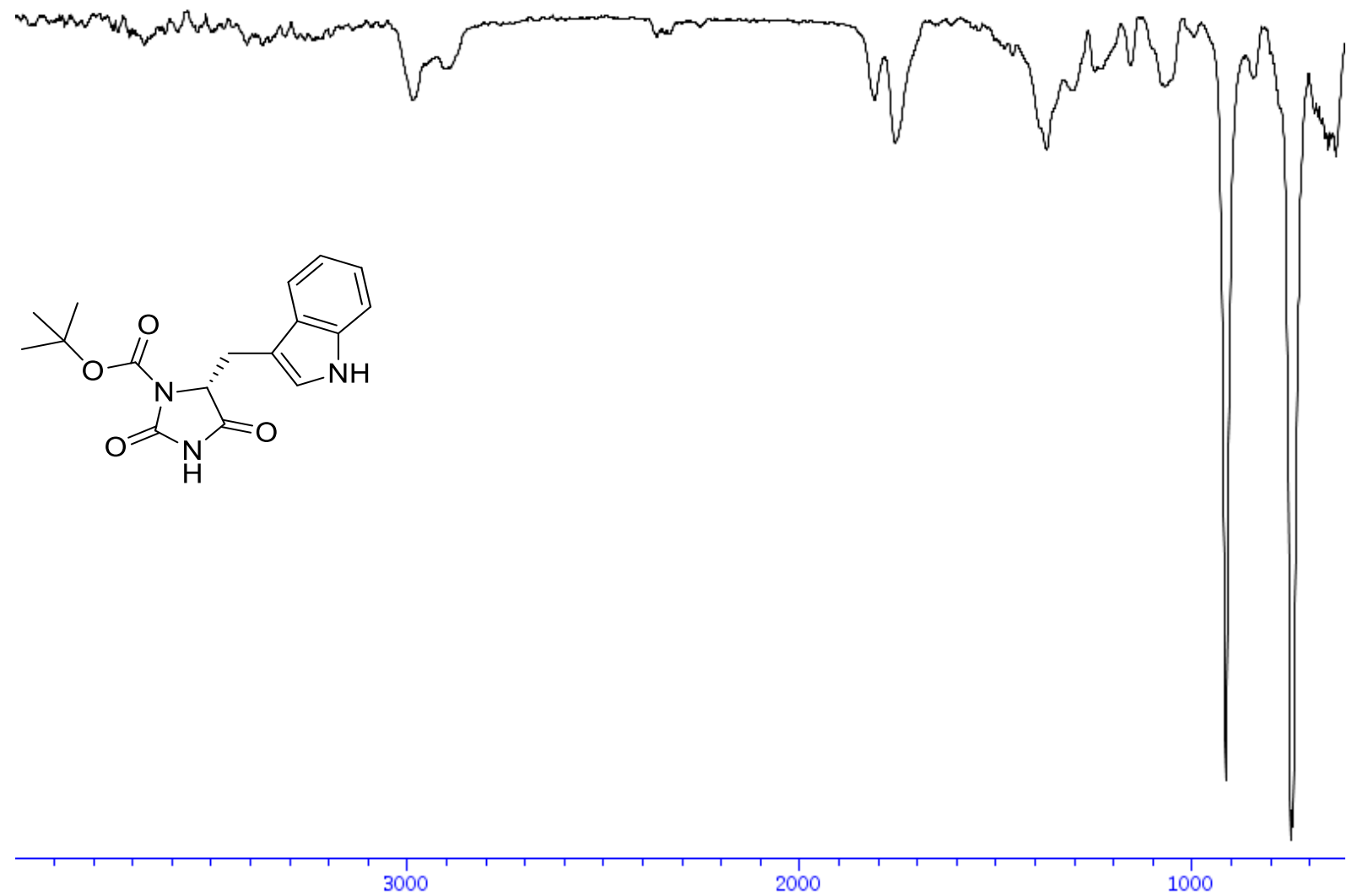


${ }^{\mathbf{1}} \mathbf{H}-\mathbf{N M R}\left(400 \mathrm{MHz}, \mathrm{CDCl}_{3}\right)$ of compound $\mathbf{8 n}$

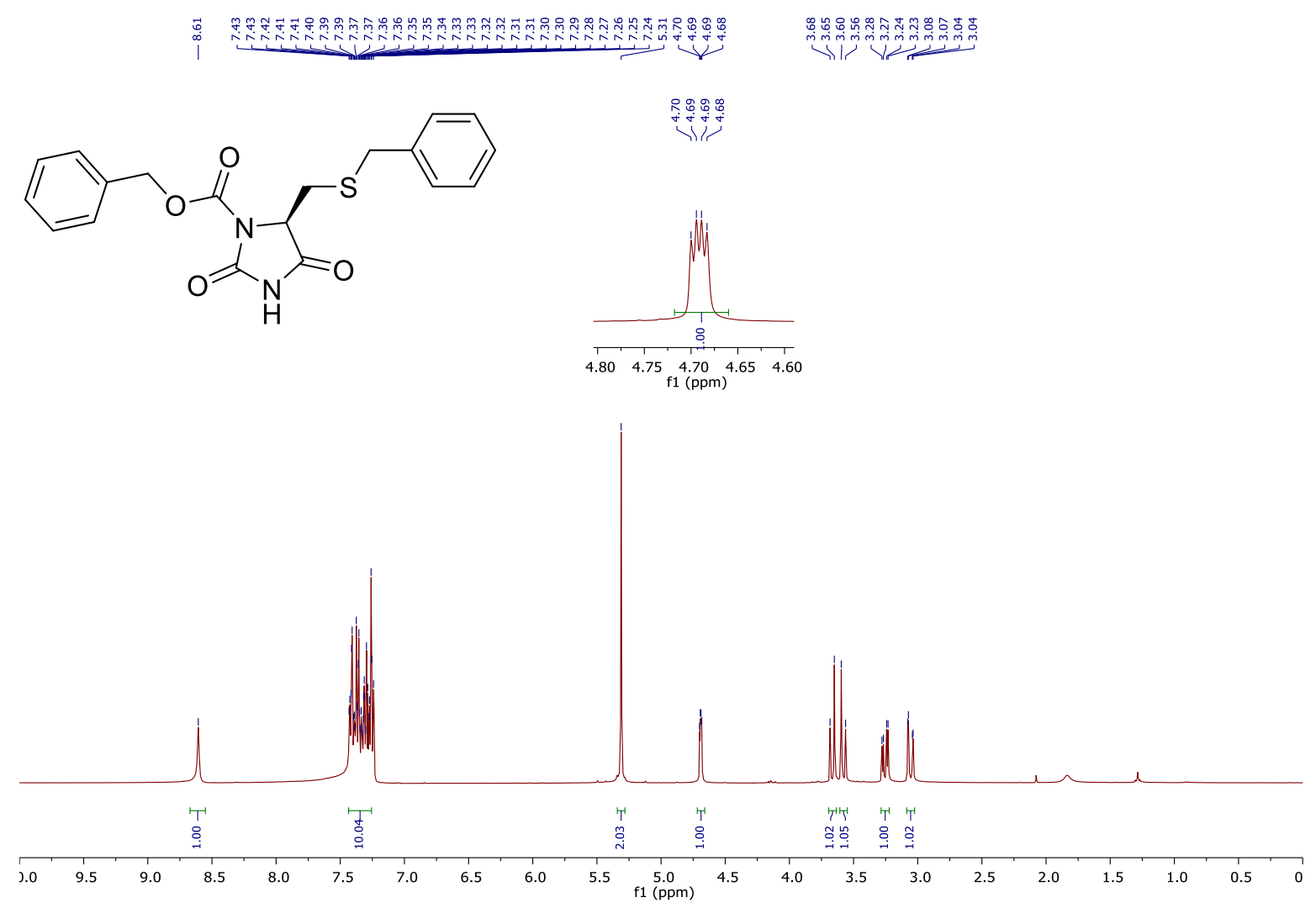

${ }^{13} \mathbf{C}$-NMR $\left(100 \mathrm{MHz}, \mathrm{CDCl}_{3}\right)$ of compound $\mathbf{8 n}$

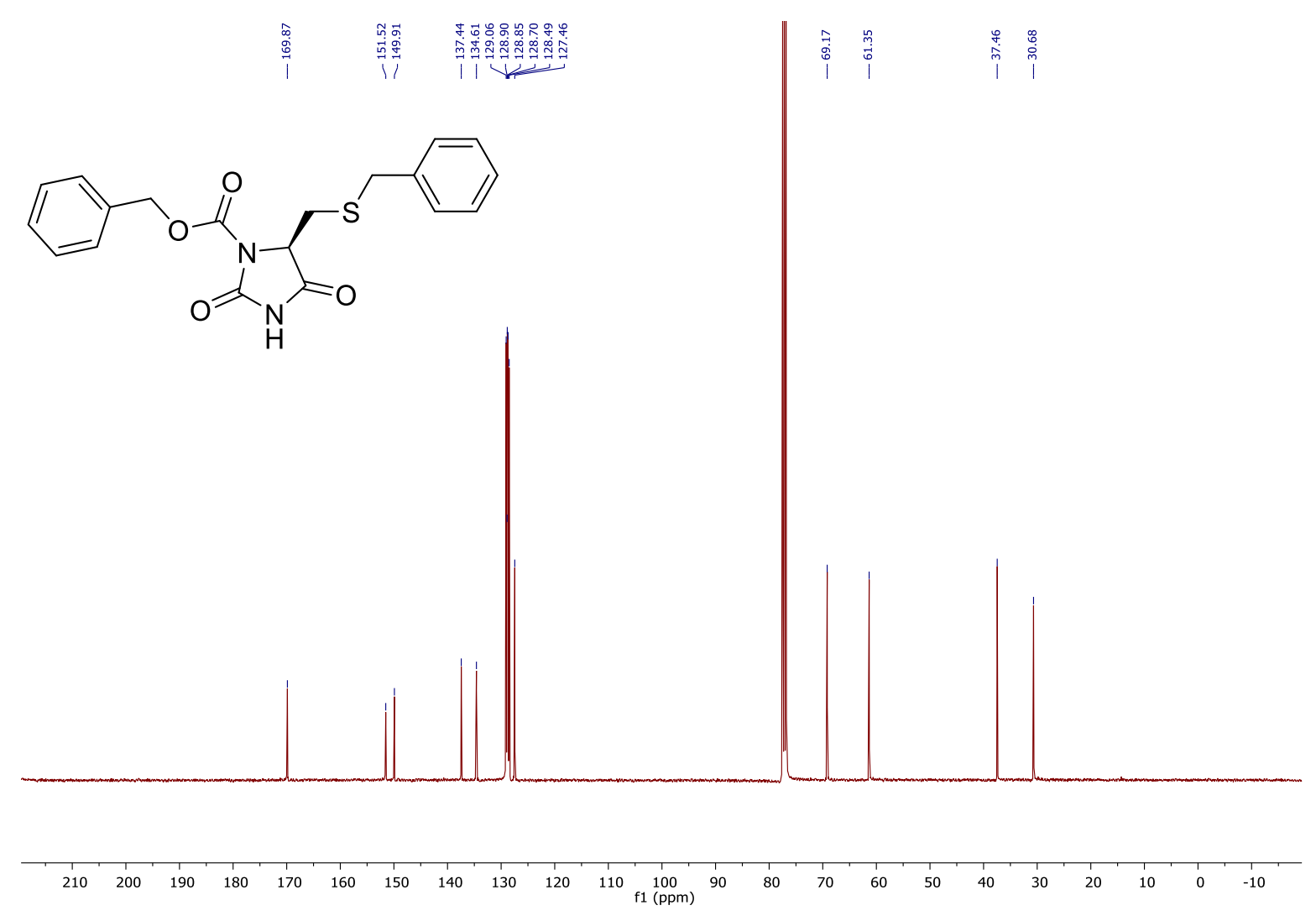


IR of compound $\mathbf{8 n}$

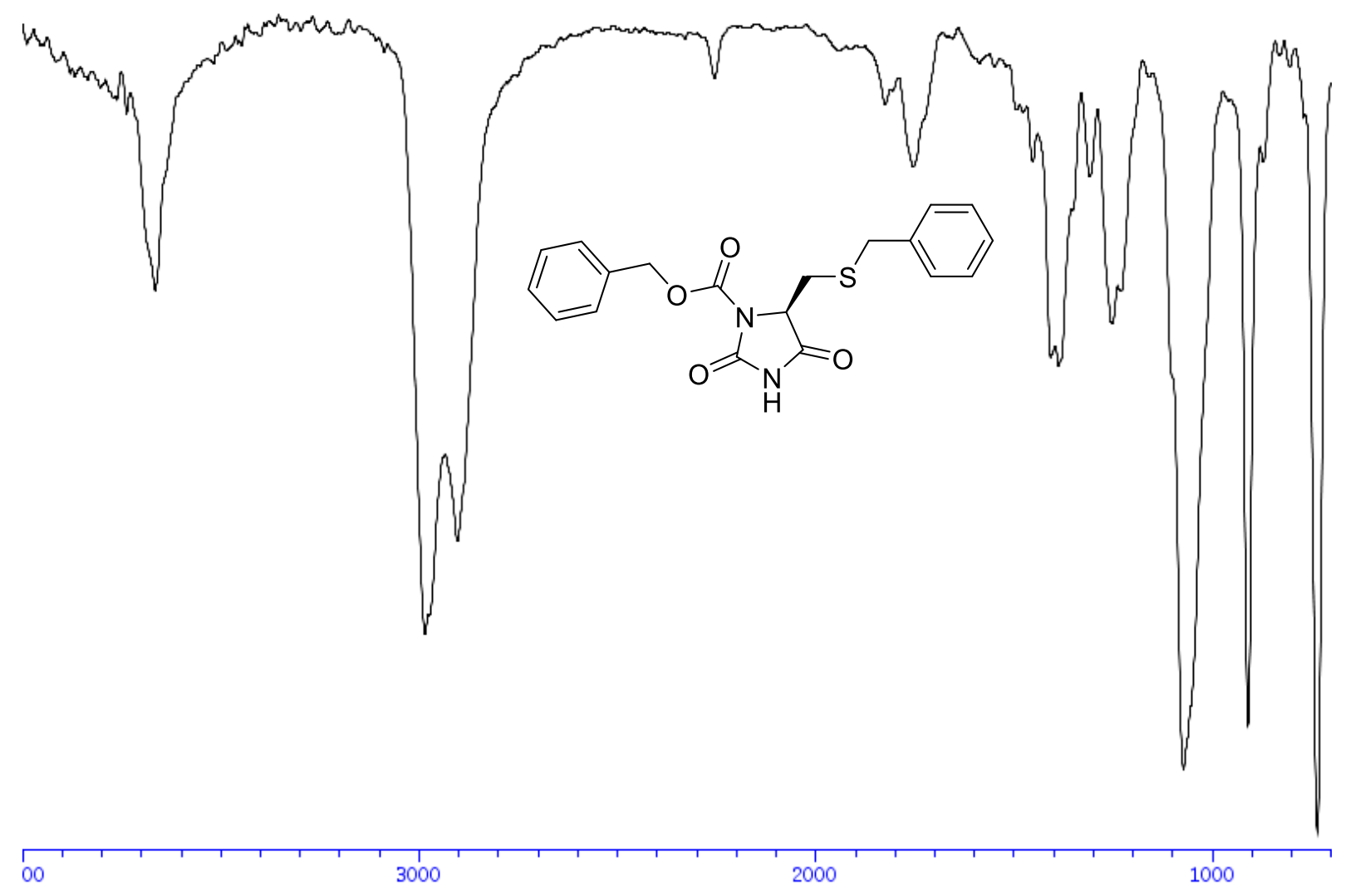


${ }^{1} \mathbf{H}-\mathbf{N M R}\left(400 \mathrm{MHz}, \mathrm{CDCl}_{3}\right)$ of compound $\mathbf{8 0}$

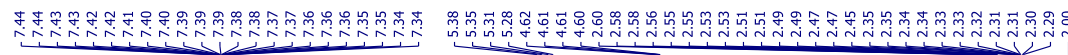

ind
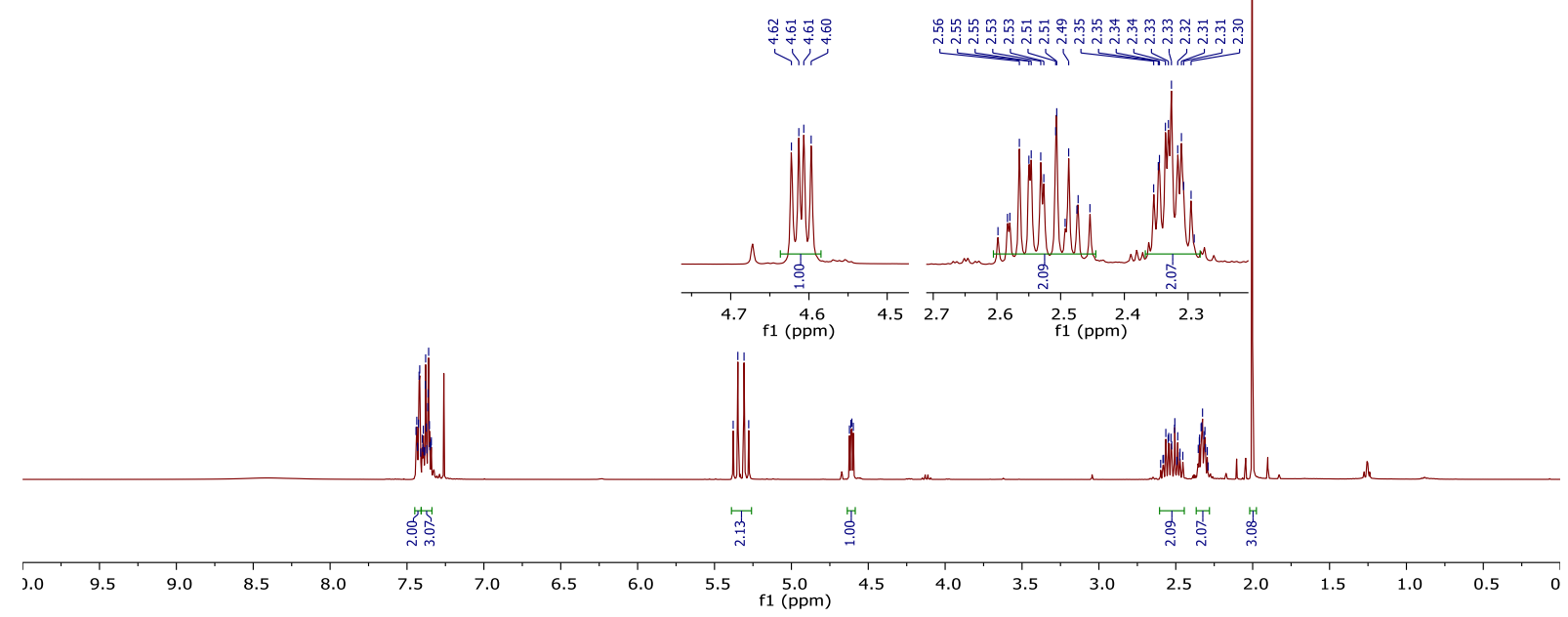

${ }^{13}$ C-NMR $\left(100 \mathrm{MHz}, \mathrm{CDCl}_{3}\right)$ of compound 80

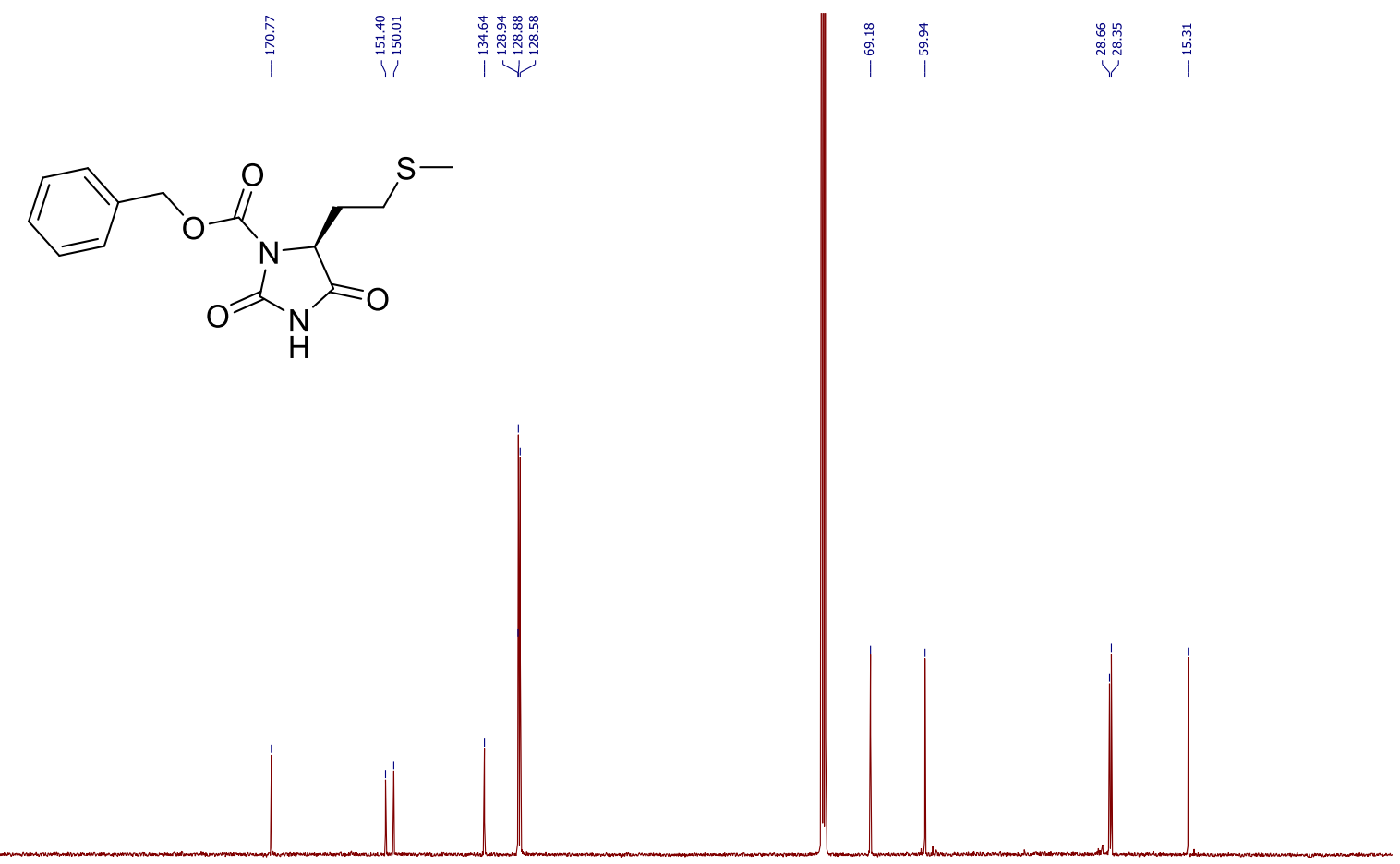

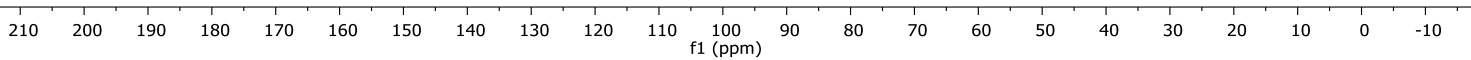


IR of compound $\mathbf{8 0}$

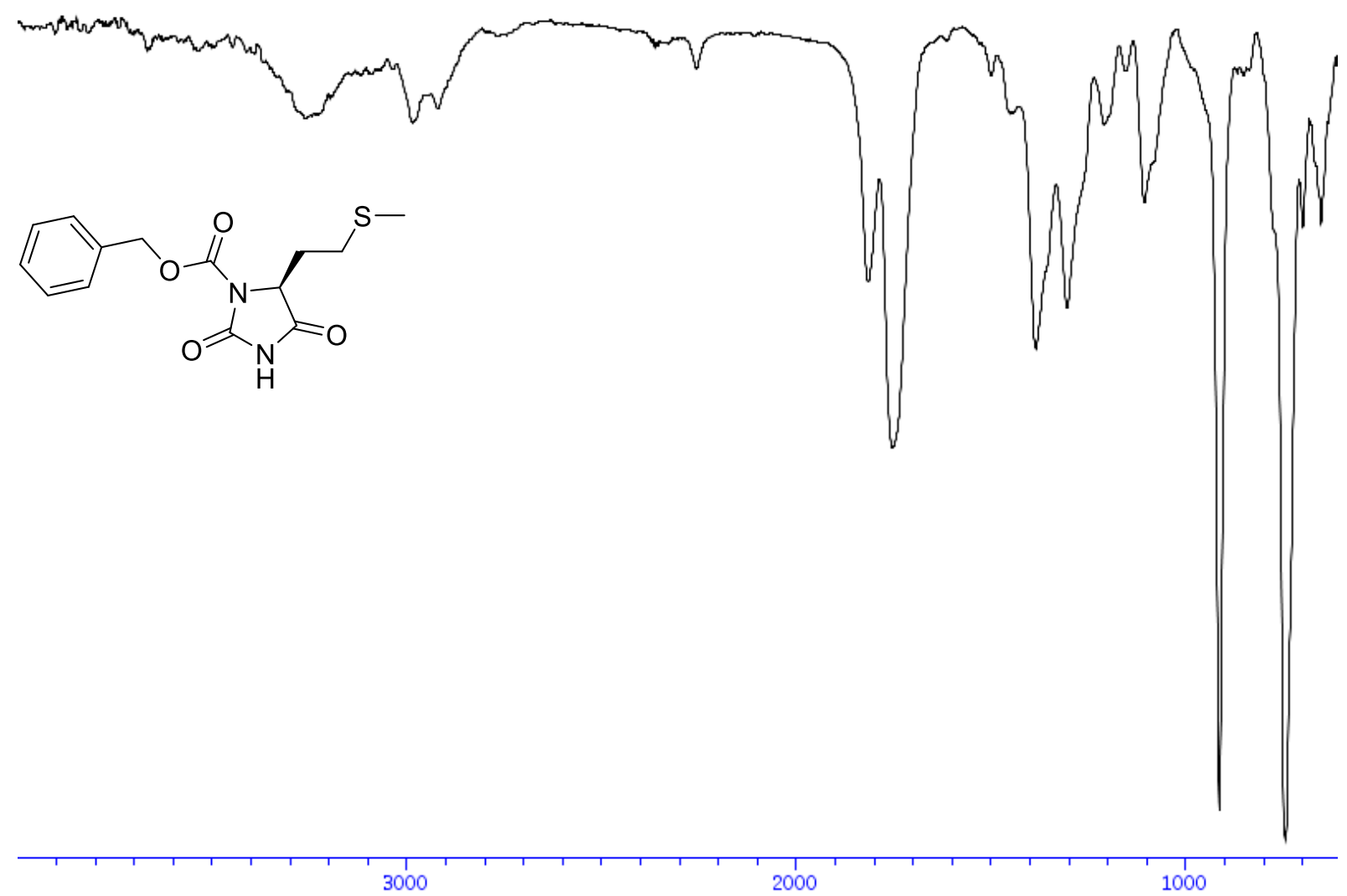


${ }^{\mathbf{1}} \mathbf{H}-\mathbf{N M R}\left(400 \mathrm{MHz}, \mathrm{CDCl}_{3}\right)$ of compound $\mathbf{8 p}$

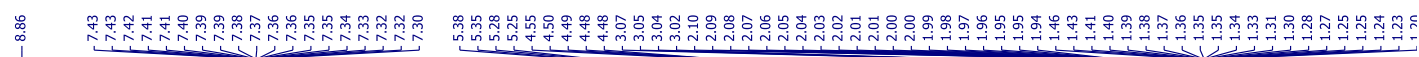<smiles>CC(C)(C)OC(=O)NCCCC1C(=O)NC(=O)N1C(=O)OCc1ccccc1</smiles>
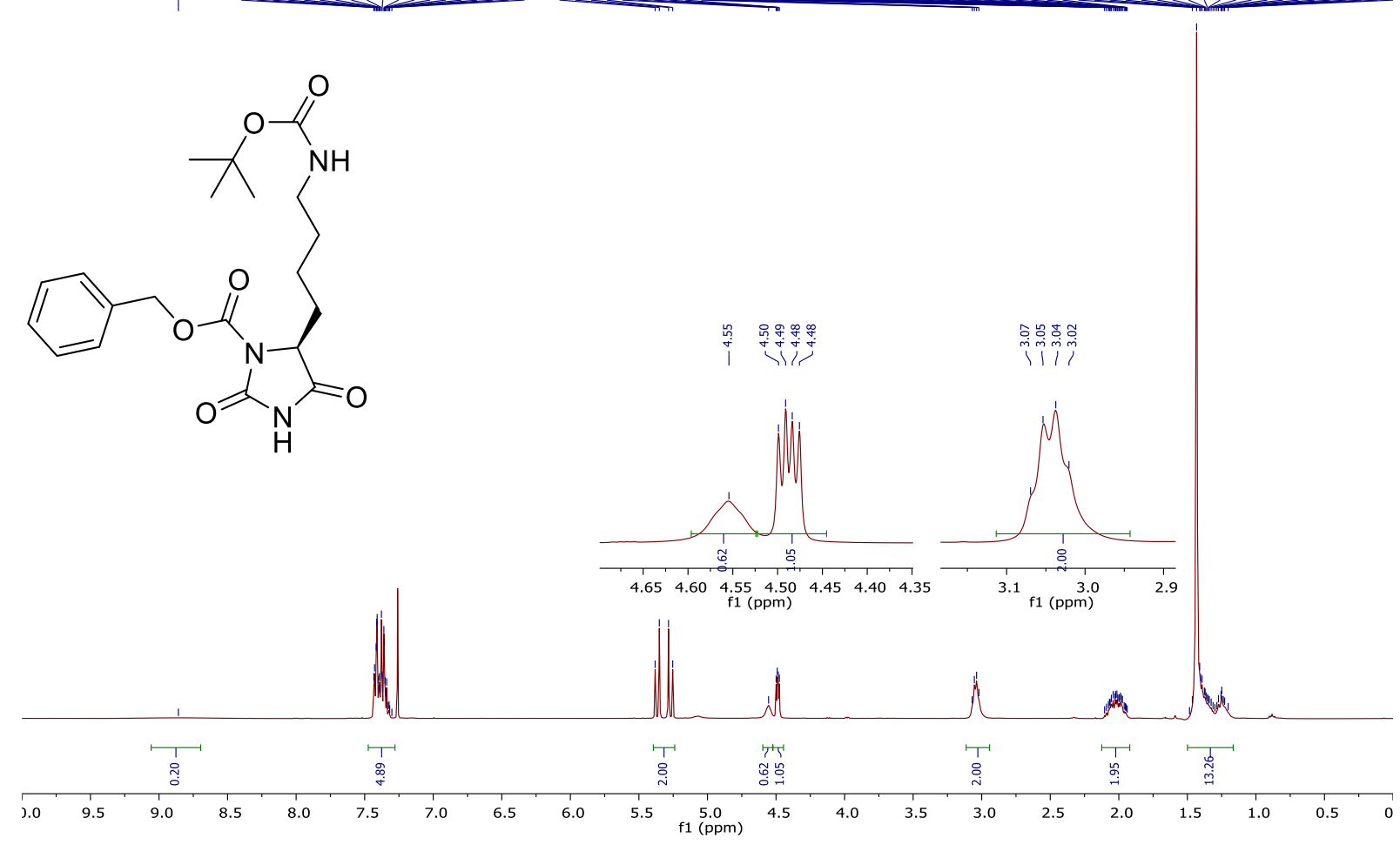

${ }^{13} \mathbf{C}-\mathbf{N M R}\left(100 \mathrm{MHz}, \mathrm{CDCl}_{3}\right)$ of compound $\mathbf{8 p}$

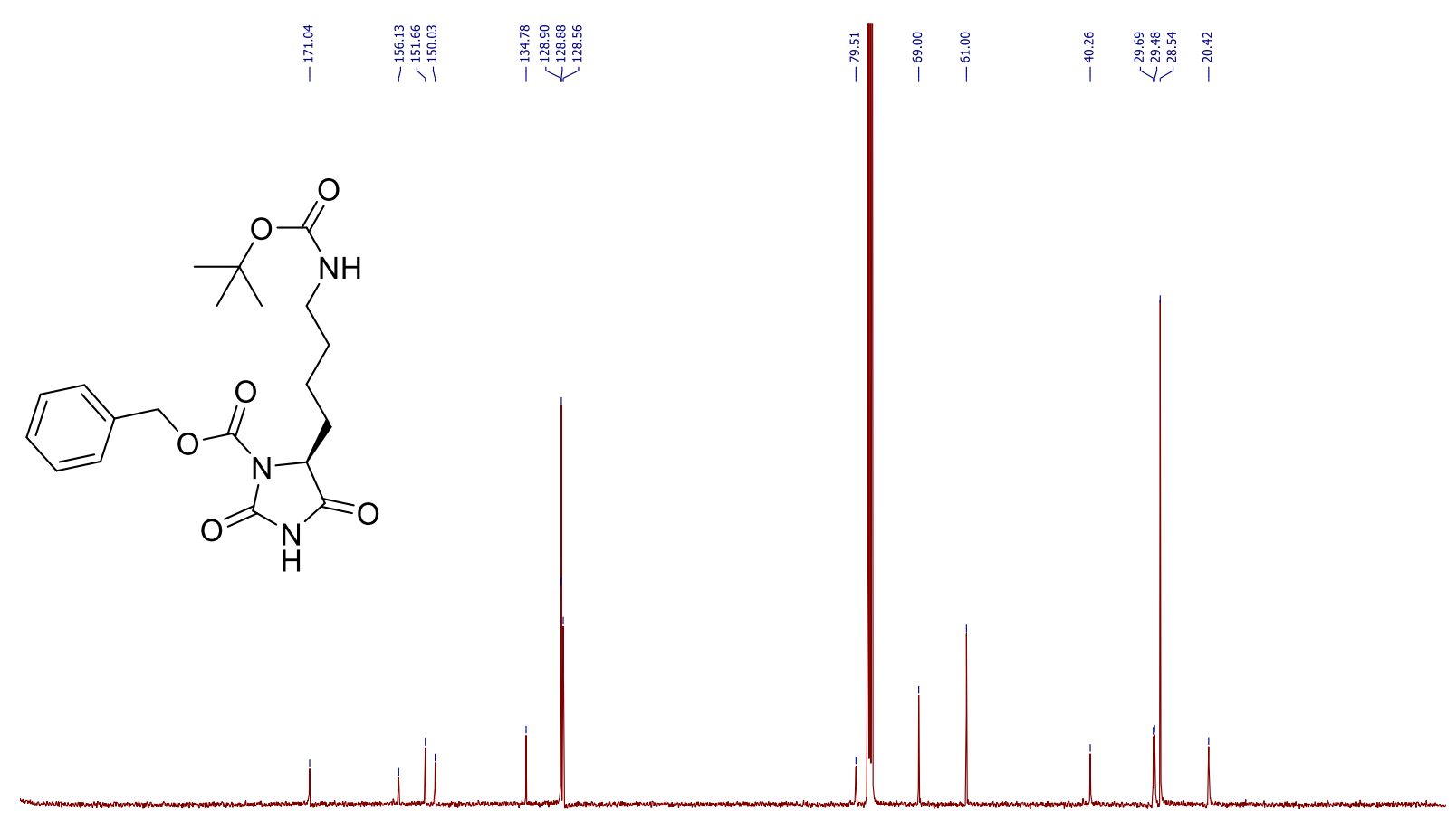

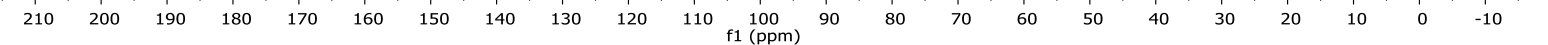


IR of compound $\mathbf{8 p}$

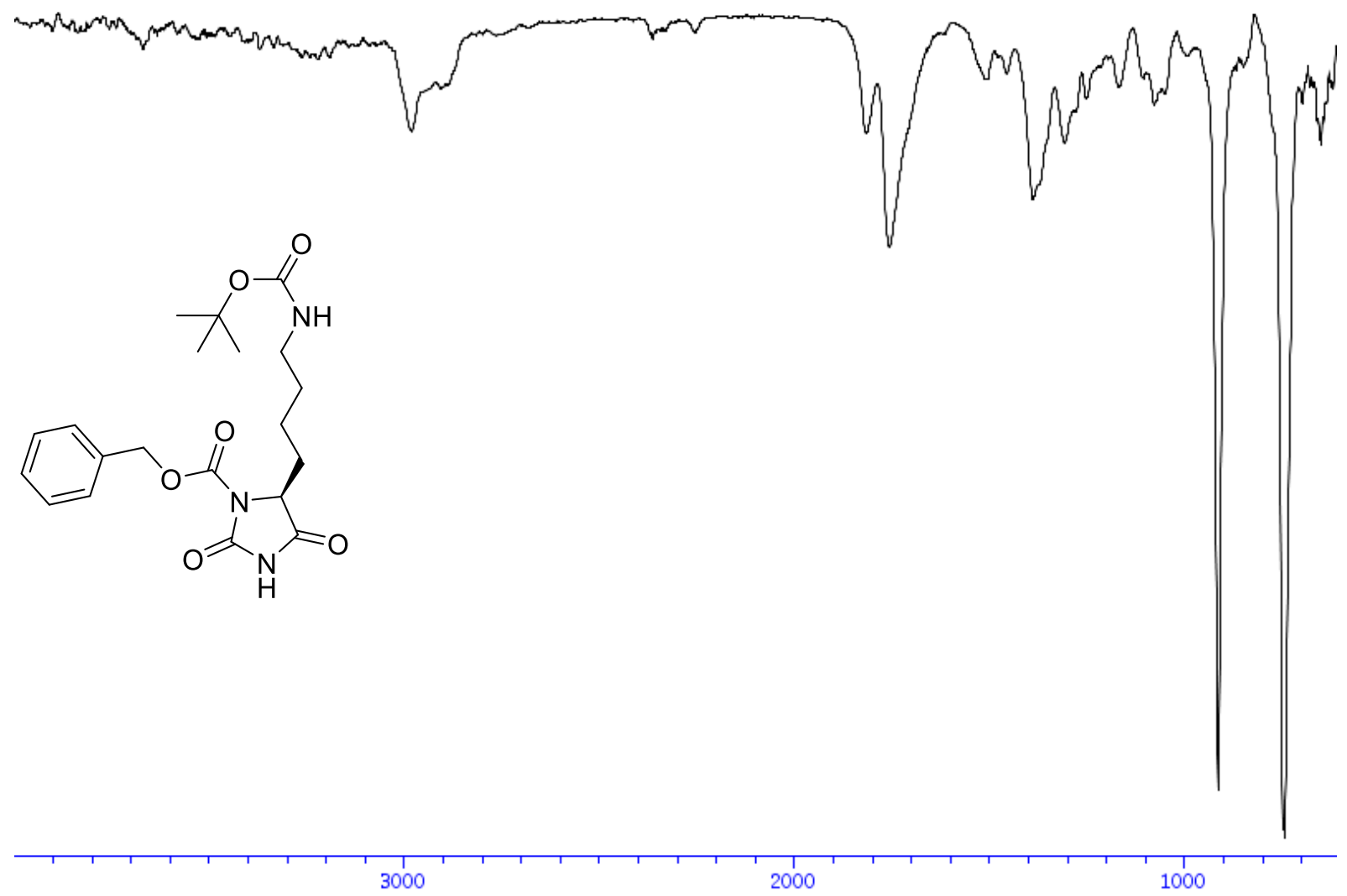


${ }^{\mathbf{1}} \mathbf{H}-\mathbf{N M R}\left(400 \mathrm{MHz}, \mathrm{CDCl}_{3}\right)$ of compound $\mathbf{8 q}$

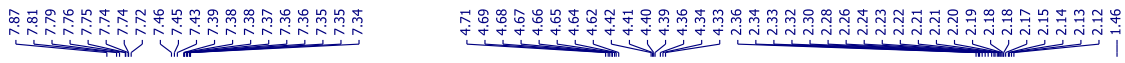
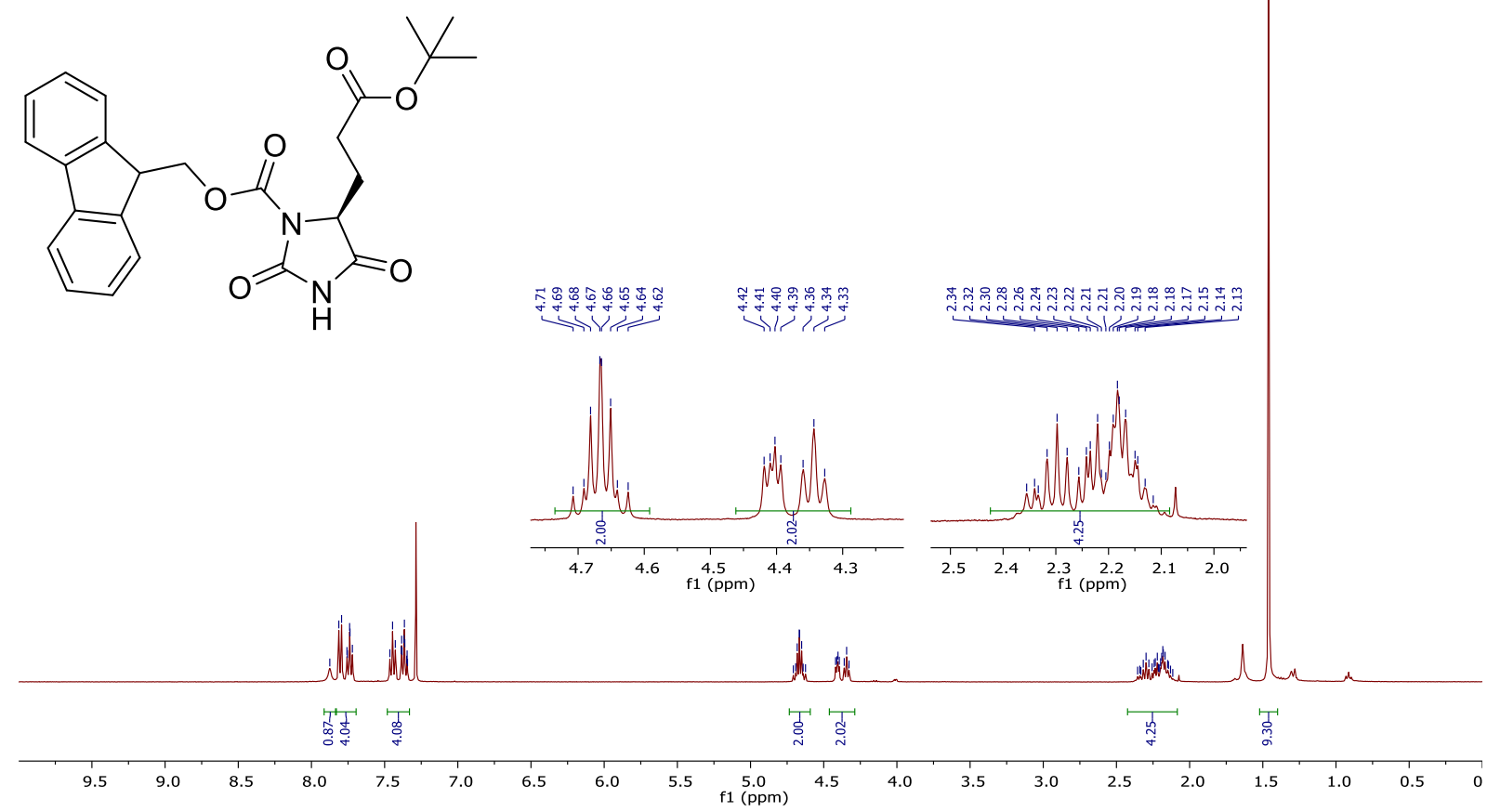

${ }^{13} \mathbf{C}$-NMR $\left(100 \mathrm{MHz}, \mathrm{CDCl}_{3}\right)$ of compound $\mathbf{8 q}$
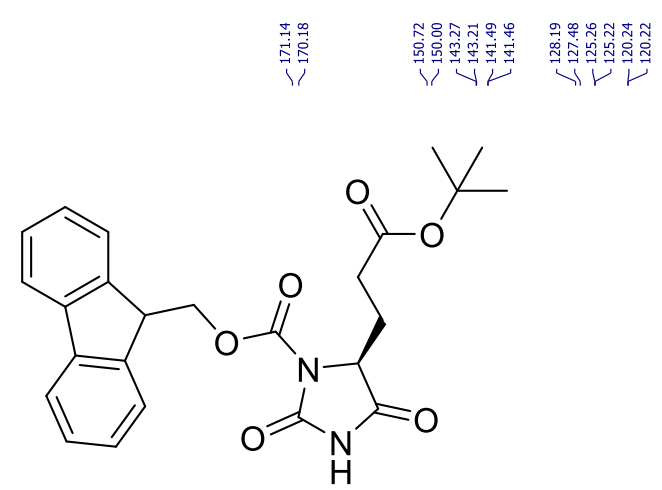

垶

$\begin{array}{lllllllllll}210 & 200 & 190 & 180 & 170 & 160 & 150 & 140 & 130 & 120 & 110 \\ \mathrm{f} 1(\mathrm{ppm}) & 100 & 90\end{array}$ 
IR of compound $\mathbf{8 q}$

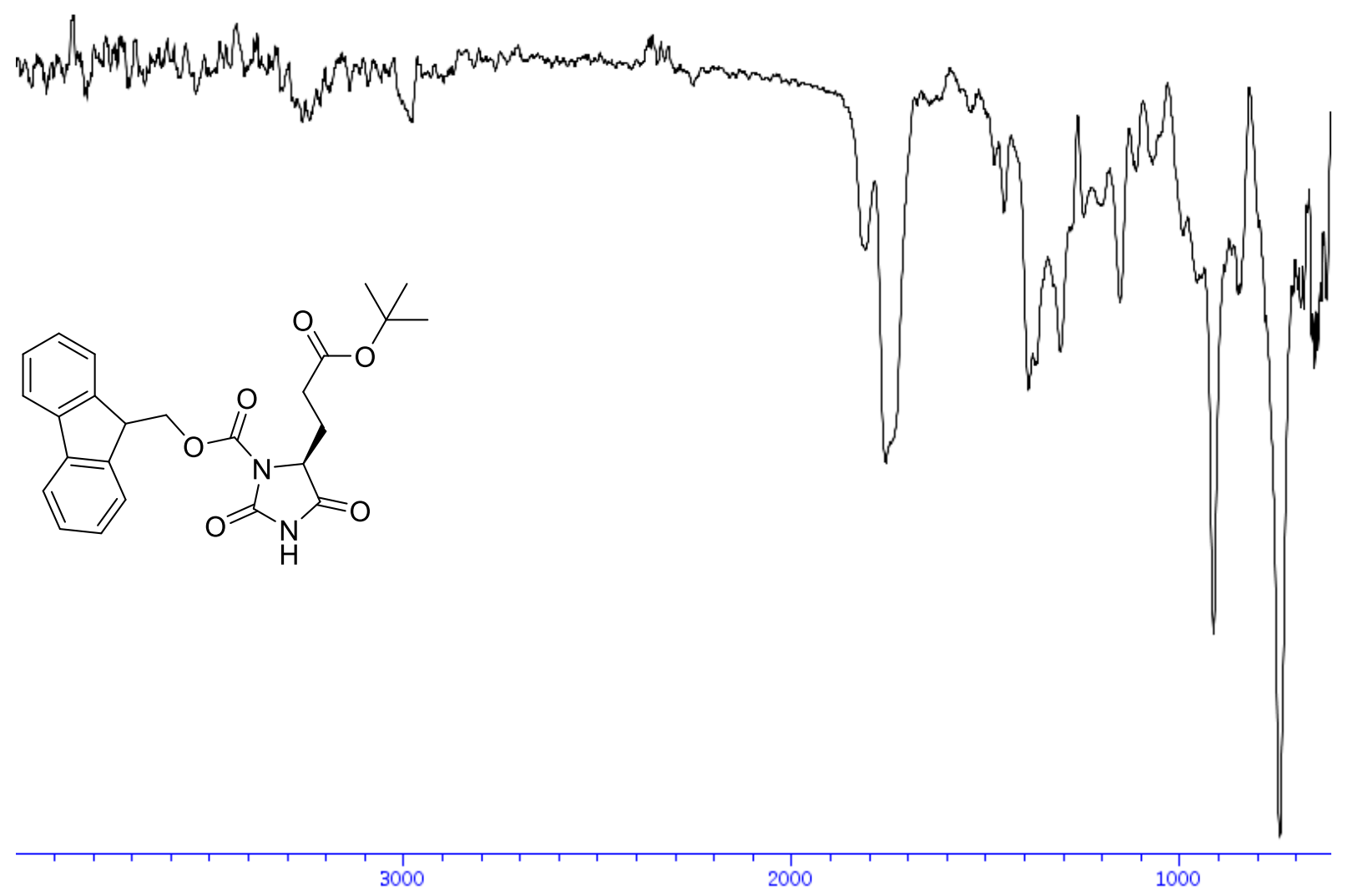


${ }^{\mathbf{1}} \mathbf{H}$-NMR $\left(400 \mathrm{MHz}, \mathrm{CDCl}_{3}\right)$ of compound $\mathbf{8 r}$

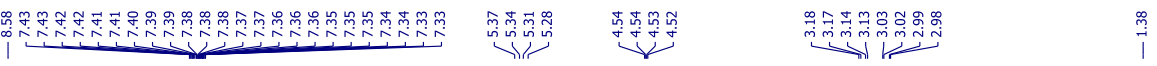<smiles>CC(C)(C)OC(=O)CC1C(=O)NC(=O)N1C(=O)OCc1ccccc1</smiles>
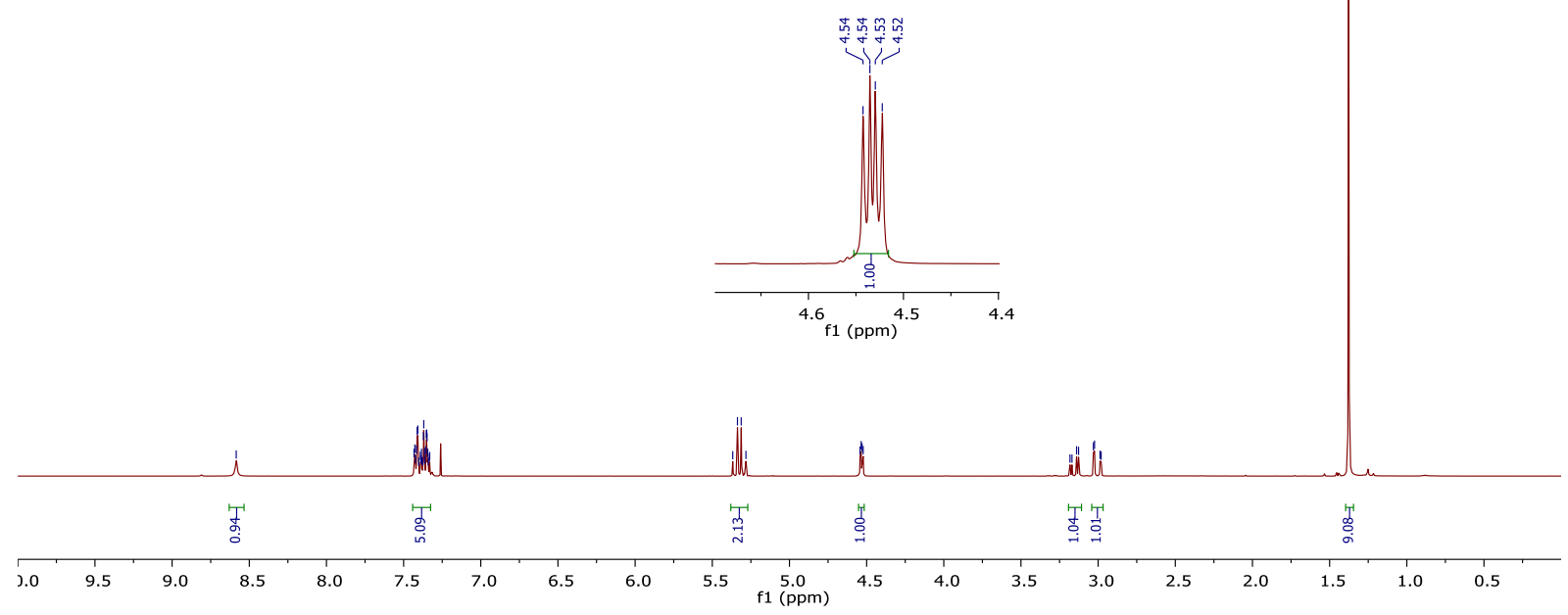

${ }^{13} \mathbf{C}-\mathbf{N M R}\left(100 \mathrm{MHz}, \mathrm{CDCl}_{3}\right)$ of compound $\mathbf{8 r}$

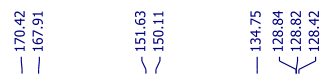
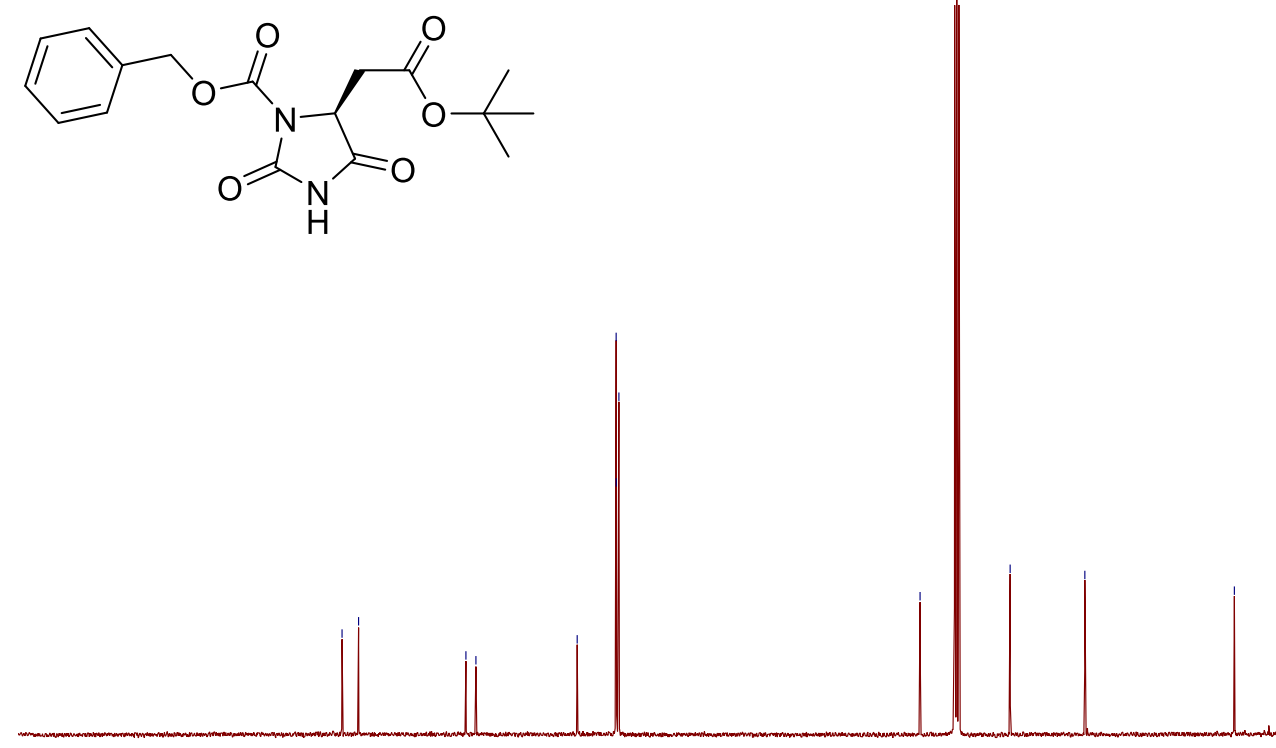

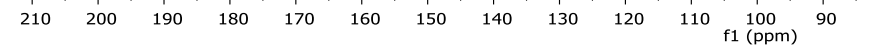


IR of compound $\mathbf{8 r}$

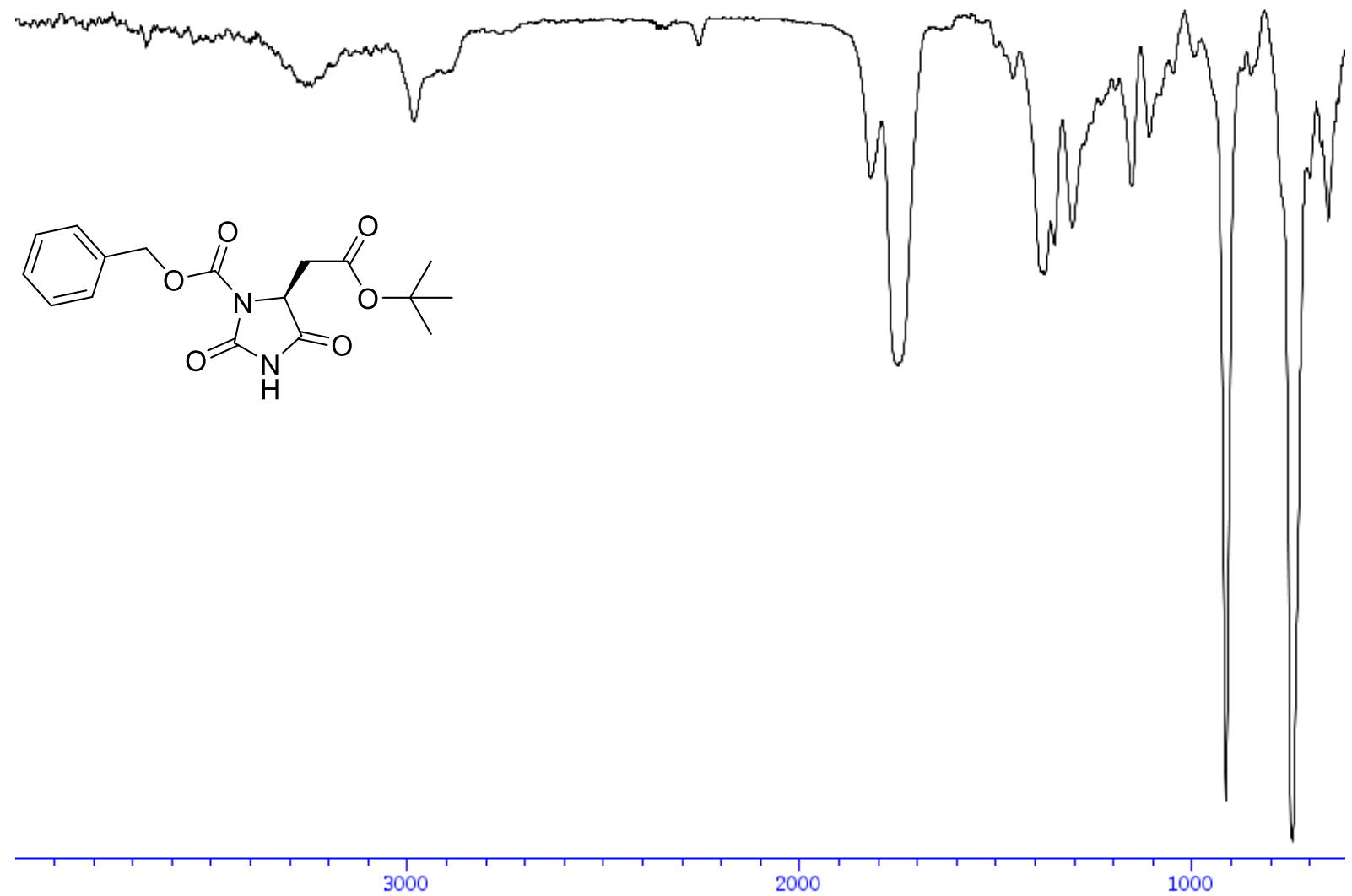


${ }^{1} \mathbf{H}-\mathbf{N M R}\left(400 \mathrm{MHz}, \mathrm{CDCl}_{3}\right)$ of compound $\mathbf{8 s}$

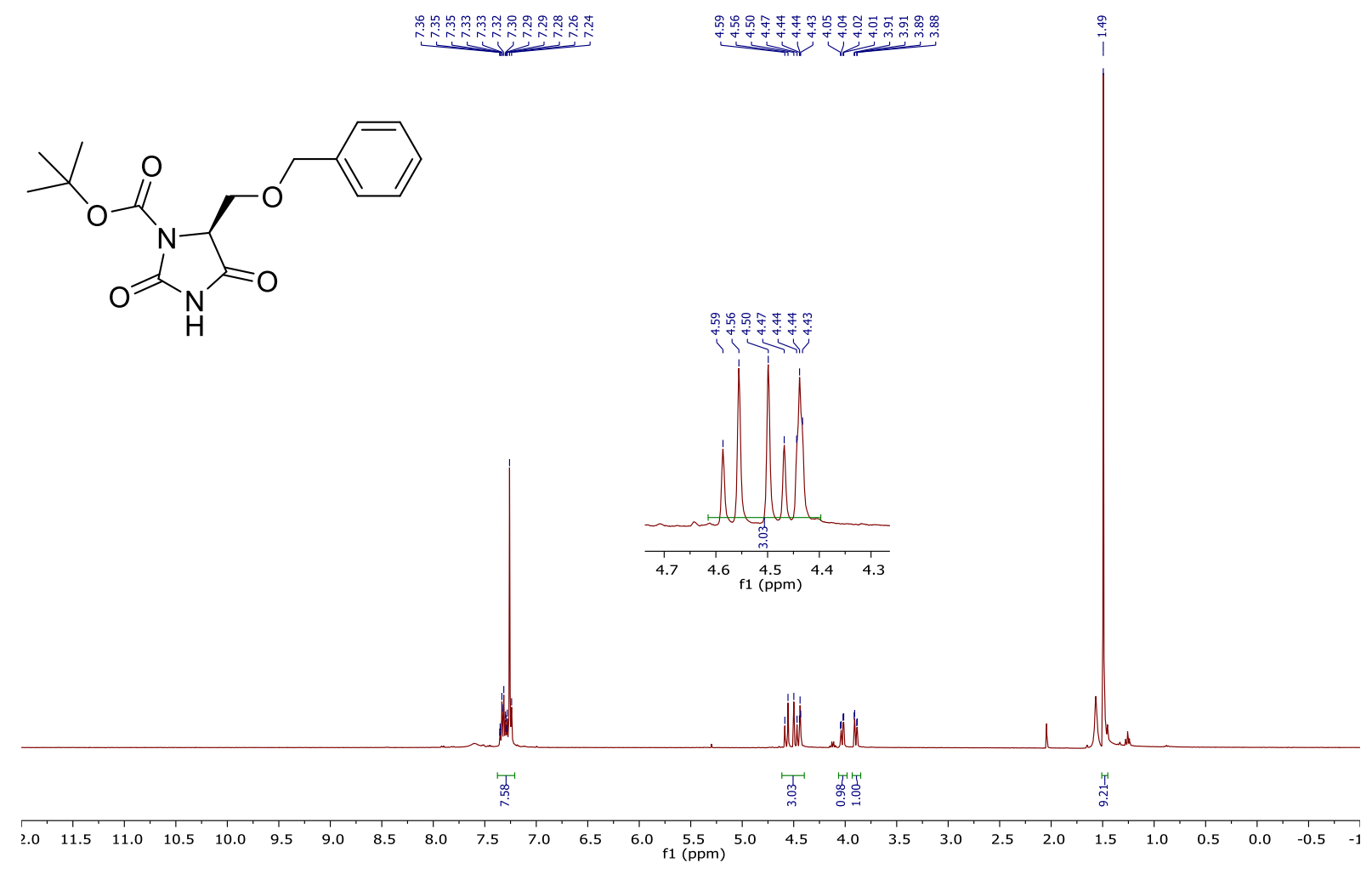

${ }^{13} \mathbf{C}-\mathbf{N M R}\left(100 \mathrm{MHz}, \mathrm{CDCl}_{3}\right)$ of compound $\mathbf{8 s}$

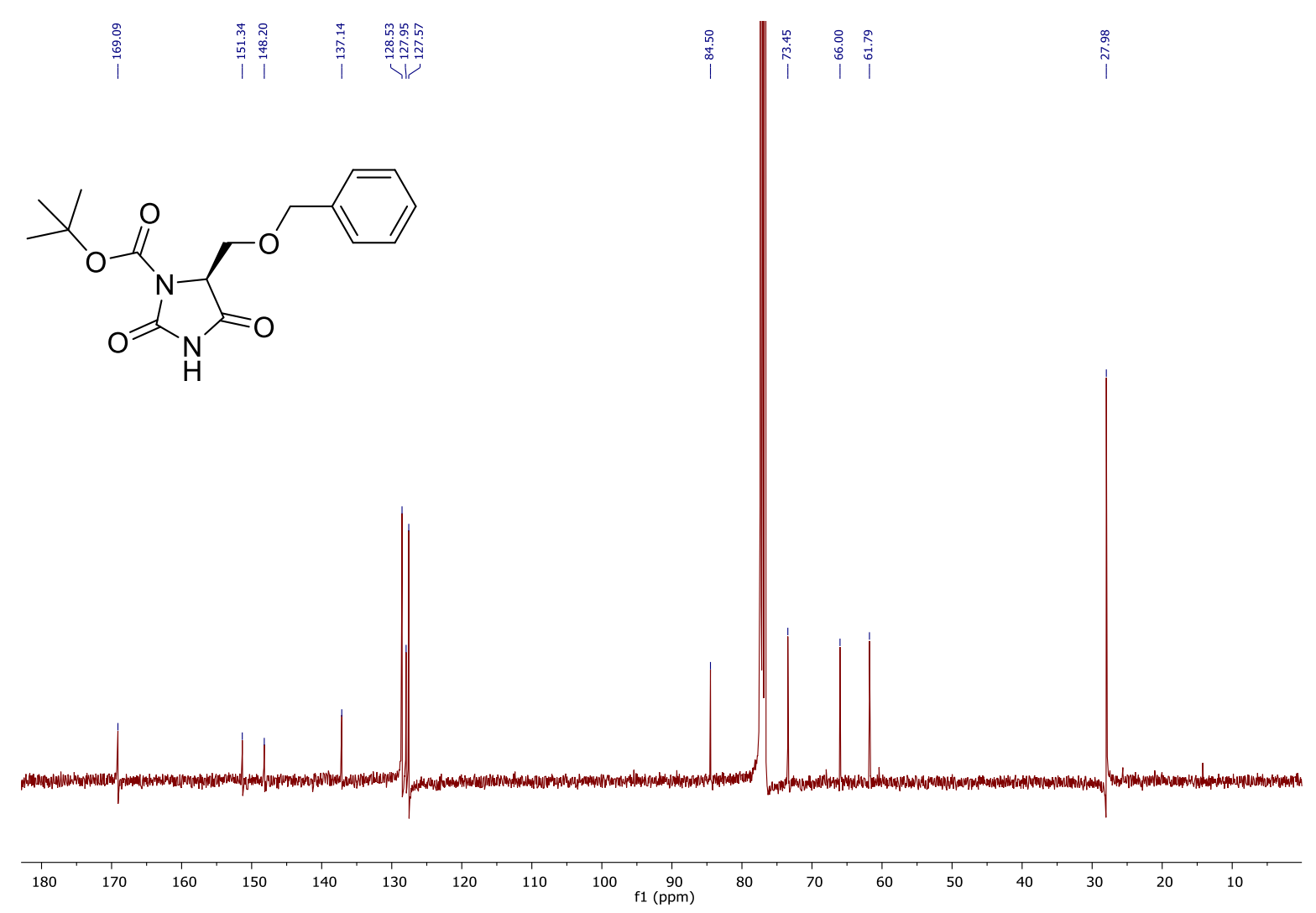


IR of compound $\mathbf{8 s}$

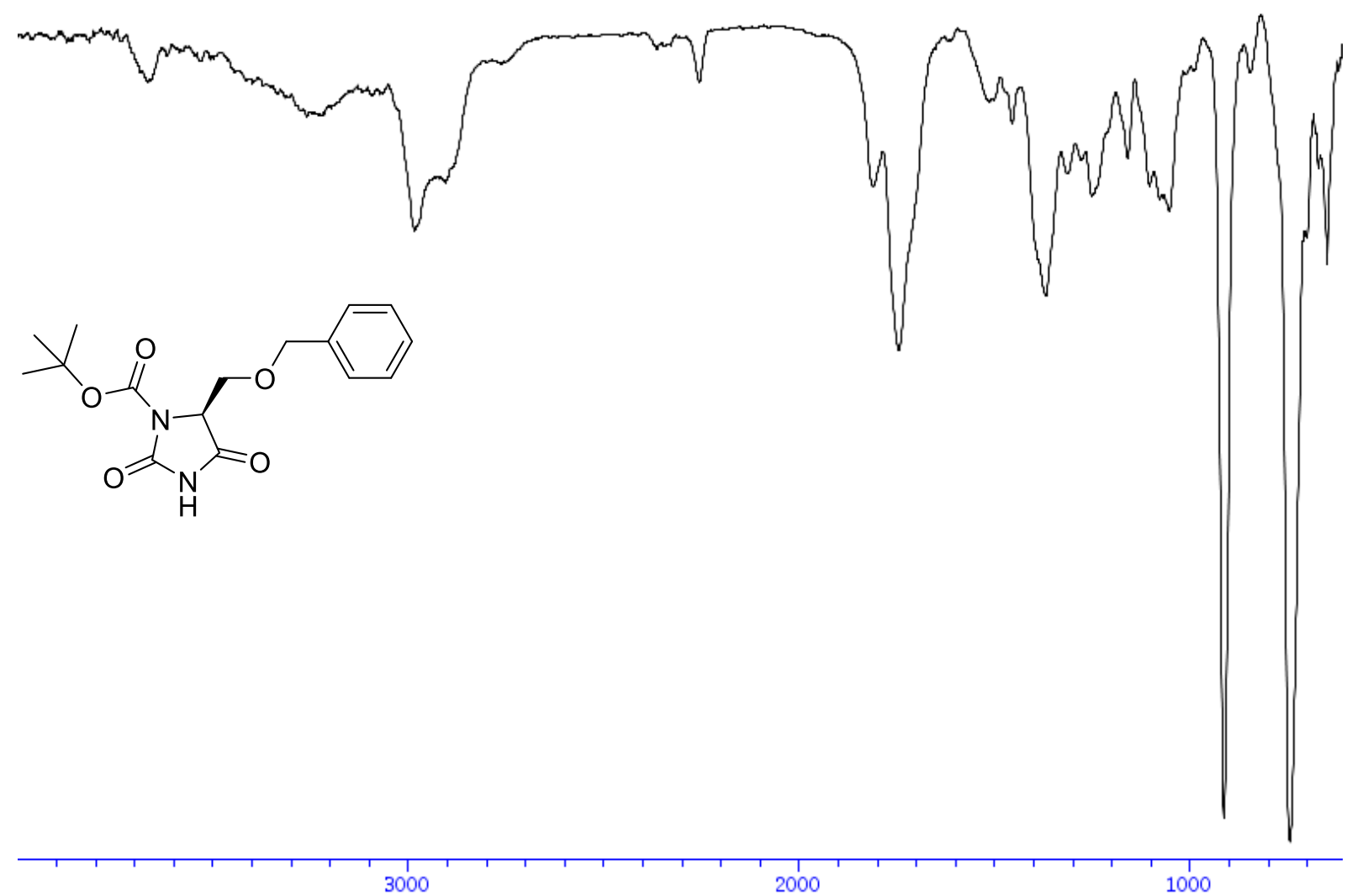


${ }^{\mathbf{1}} \mathbf{H}$-NMR $\left(400 \mathrm{MHz}, \mathrm{CDCl}_{3}\right)$ of compound $\mathbf{8 t}$

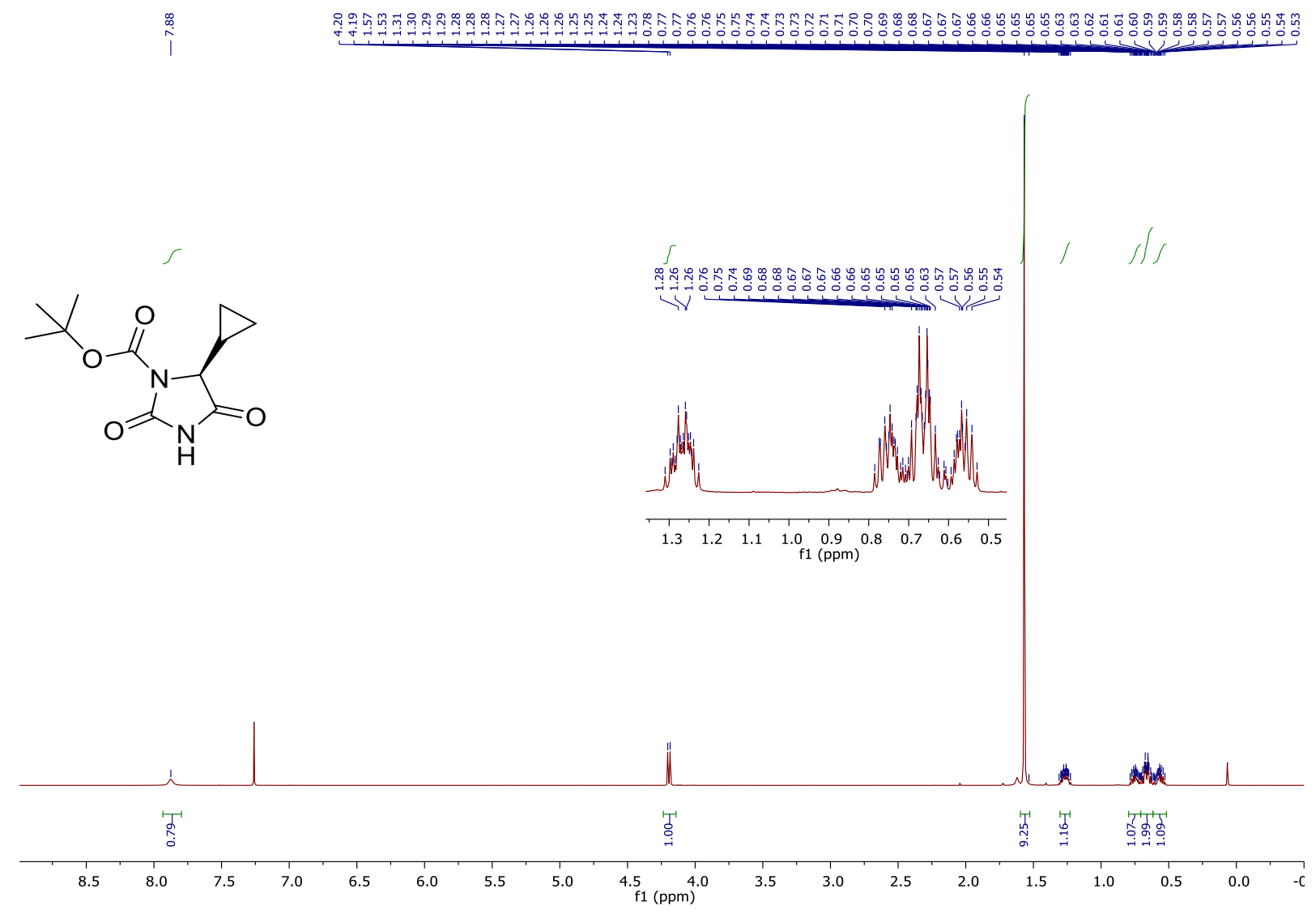

${ }^{13} \mathbf{C}-\mathbf{N M R}\left(100 \mathrm{MHz}, \mathrm{CDCl}_{3}\right)$ of compound $\mathbf{8 t}$

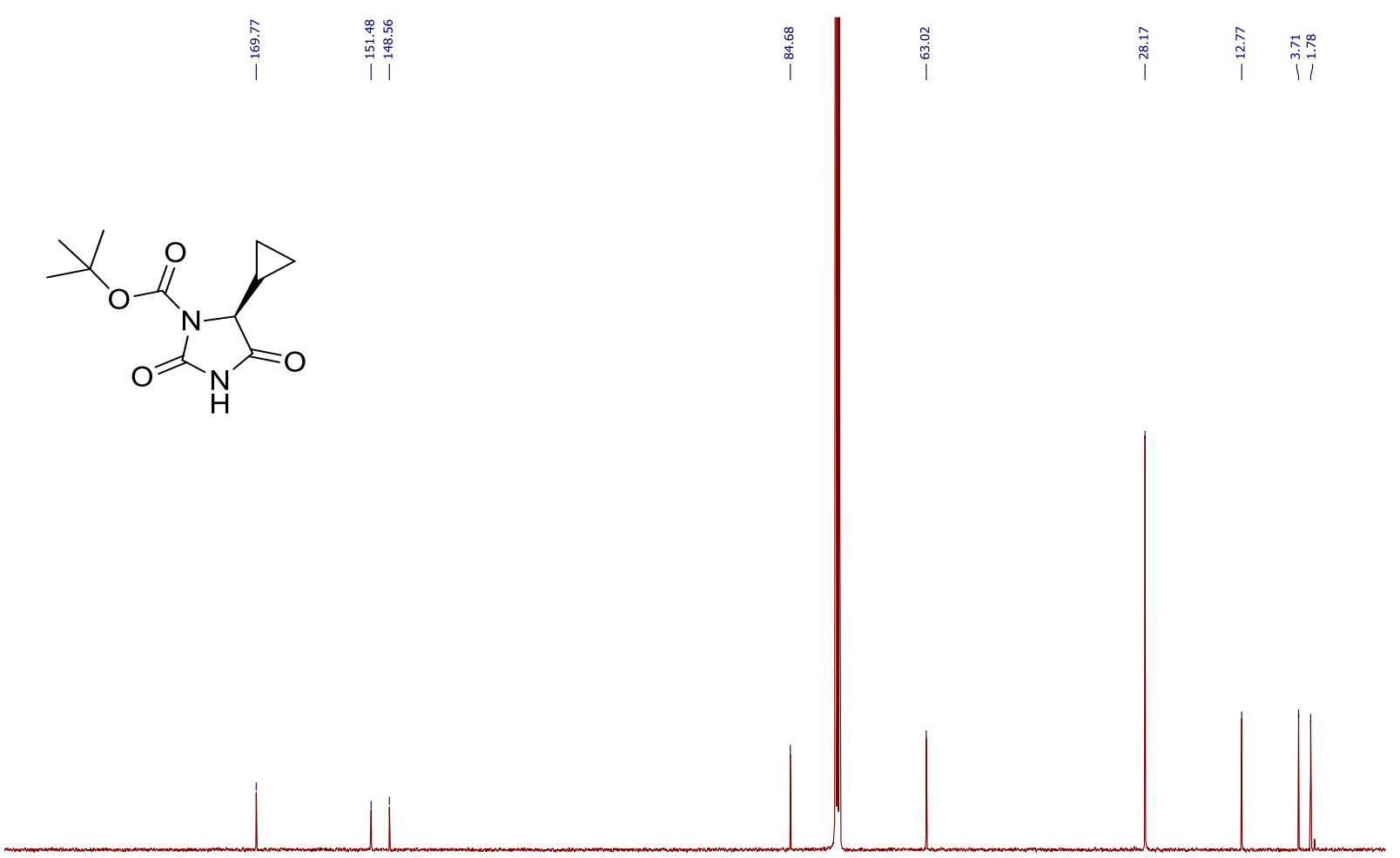

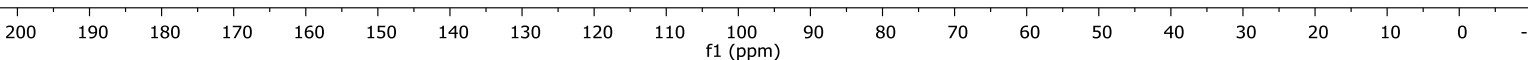


IR of compound $\mathbf{8 t}$

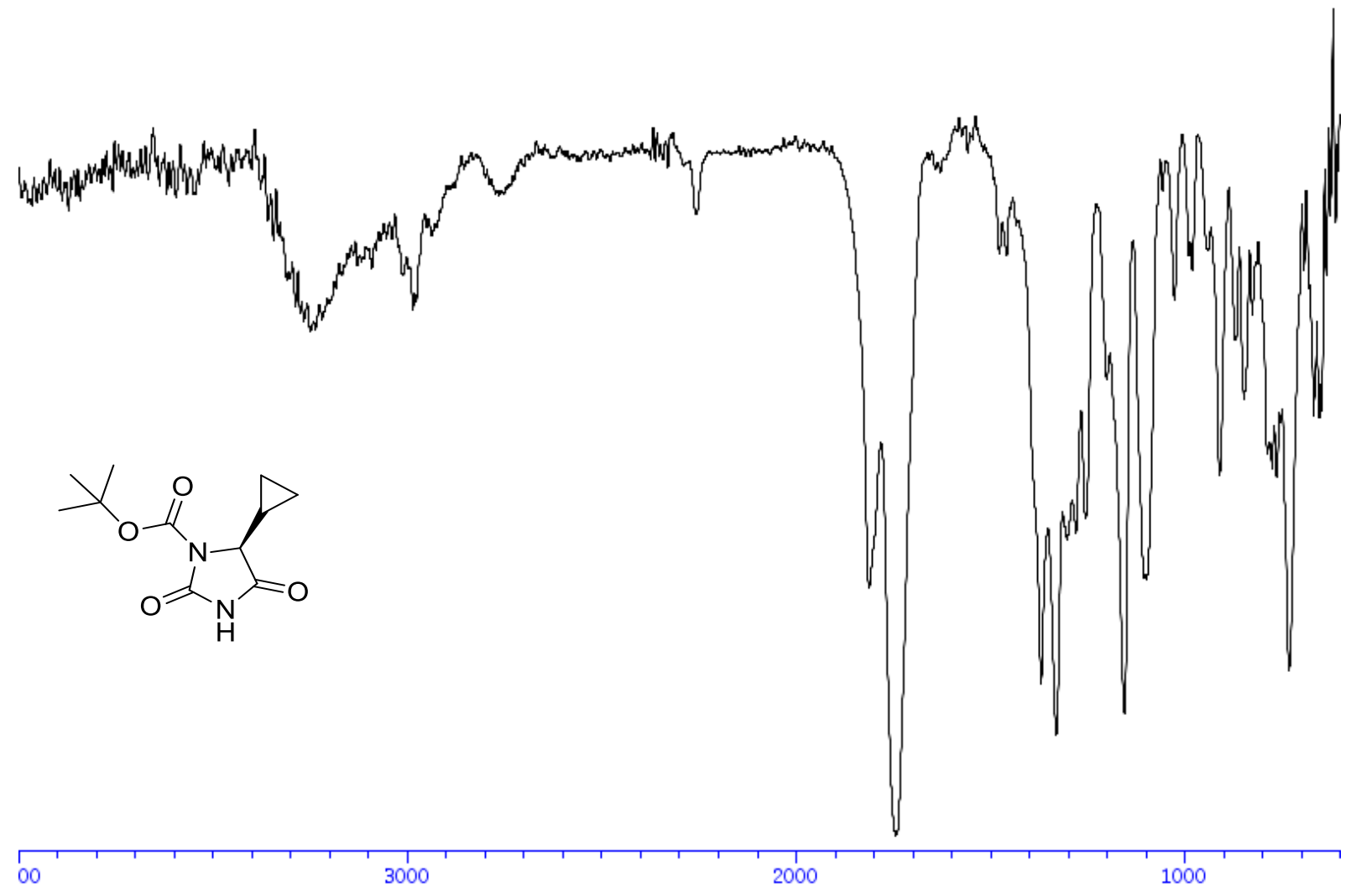


${ }^{\mathbf{1}} \mathbf{H}-\mathrm{NMR}$ (400 MHz, DMSO-d6) of compound $\mathbf{8 u}$

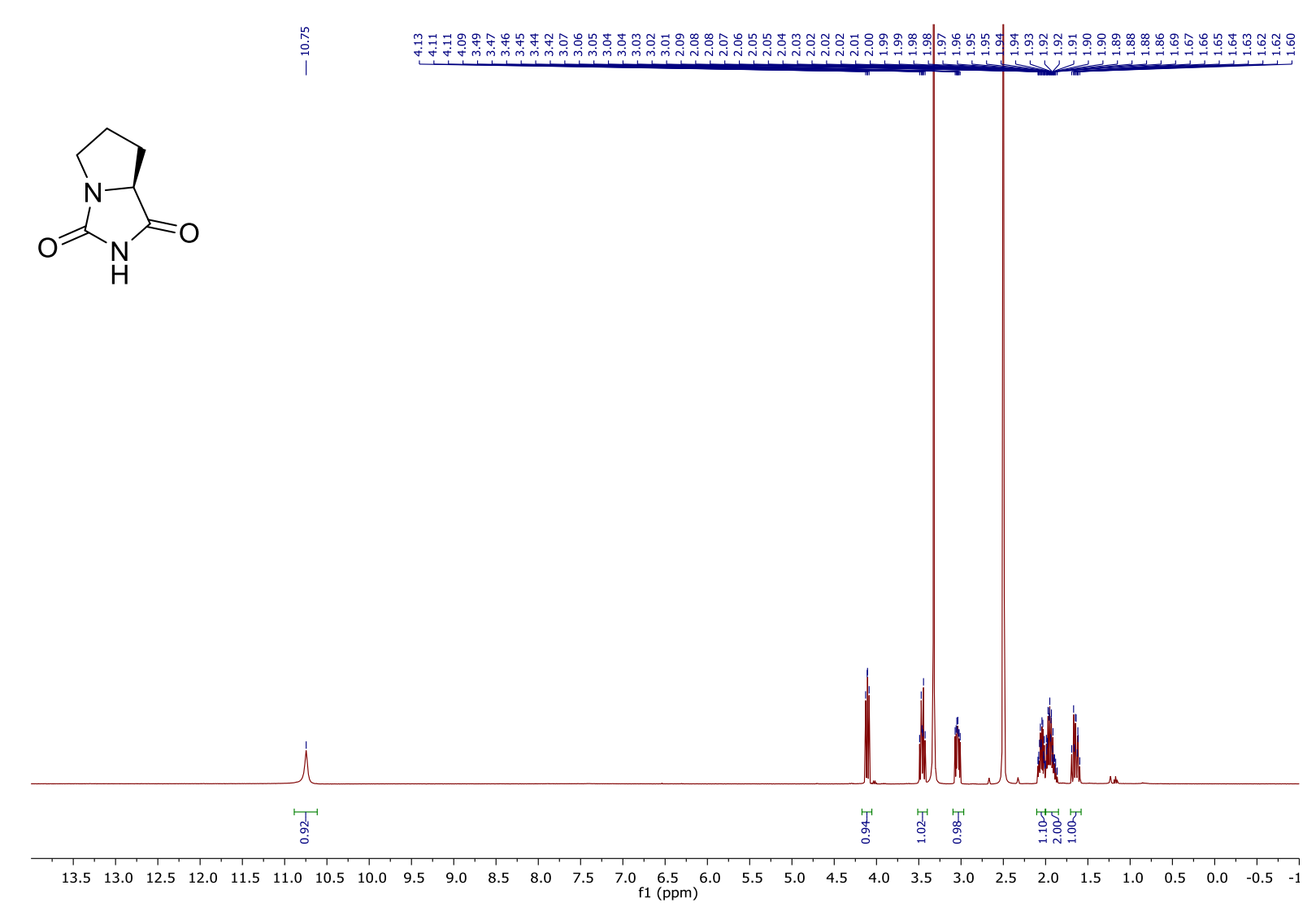

${ }^{13}$ C-NMR (100 MHz, DMSO-d6) of compound 8u

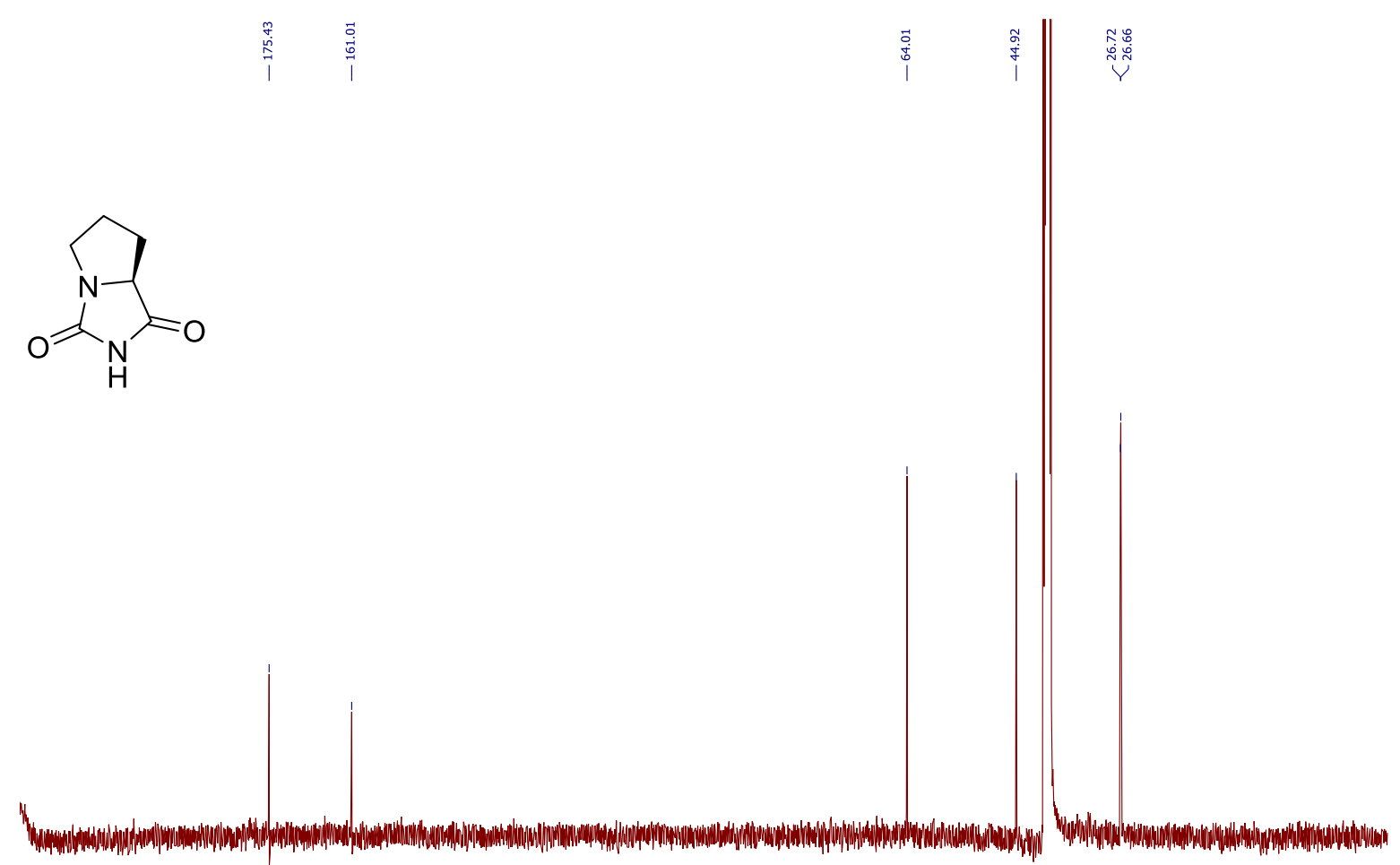

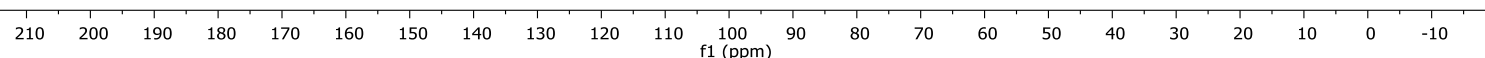


${ }^{1} \mathbf{H}-\mathbf{N M R}\left(400 \mathrm{MHz}, \mathrm{CDCl}_{3}\right)$ of compound $\mathbf{8 v}$

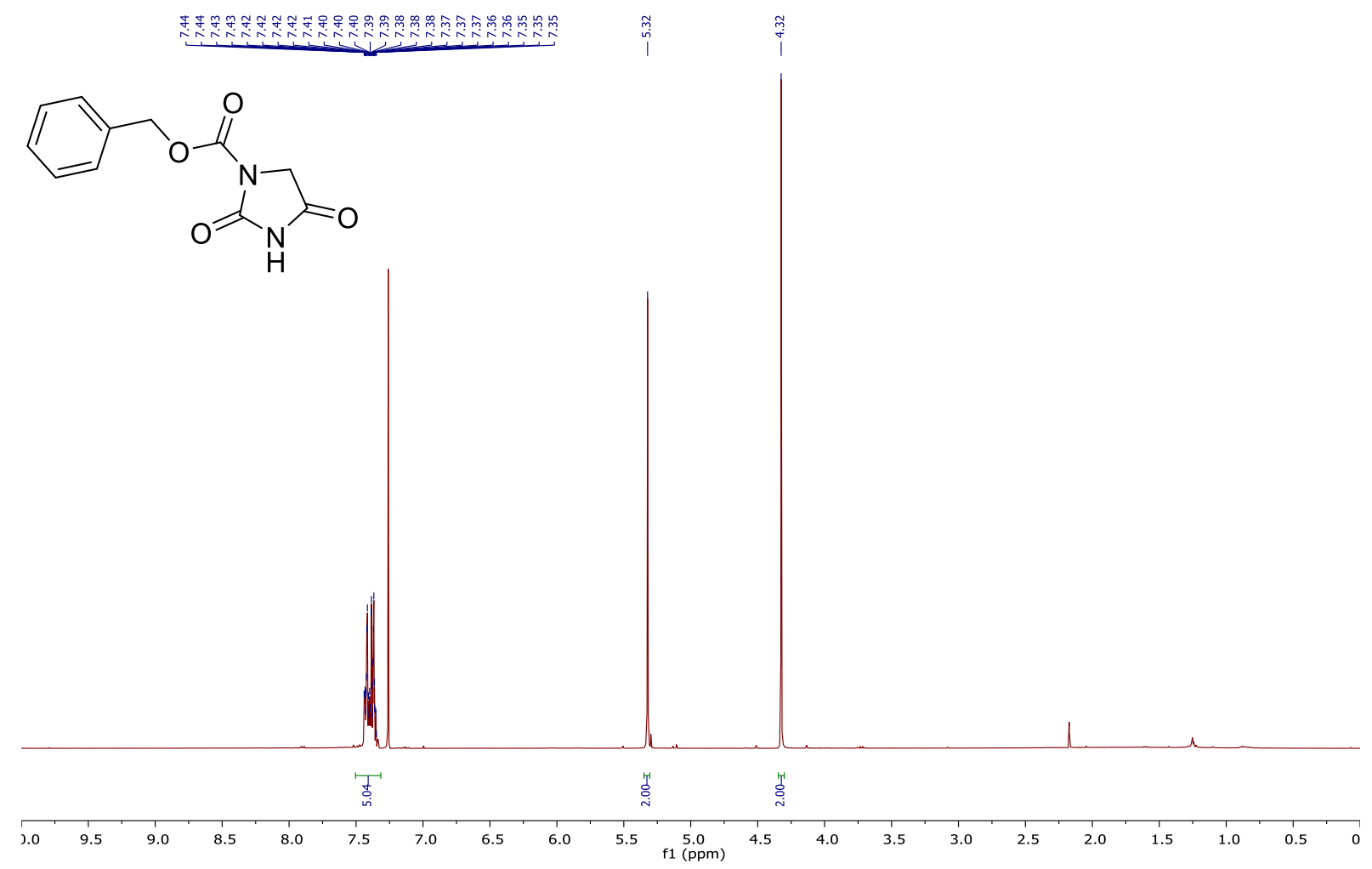

${ }^{13} \mathbf{C}-\mathbf{N M R}\left(100 \mathrm{MHz}, \mathrm{CDCl}_{3}\right)$ of compound $\mathbf{8 v}$

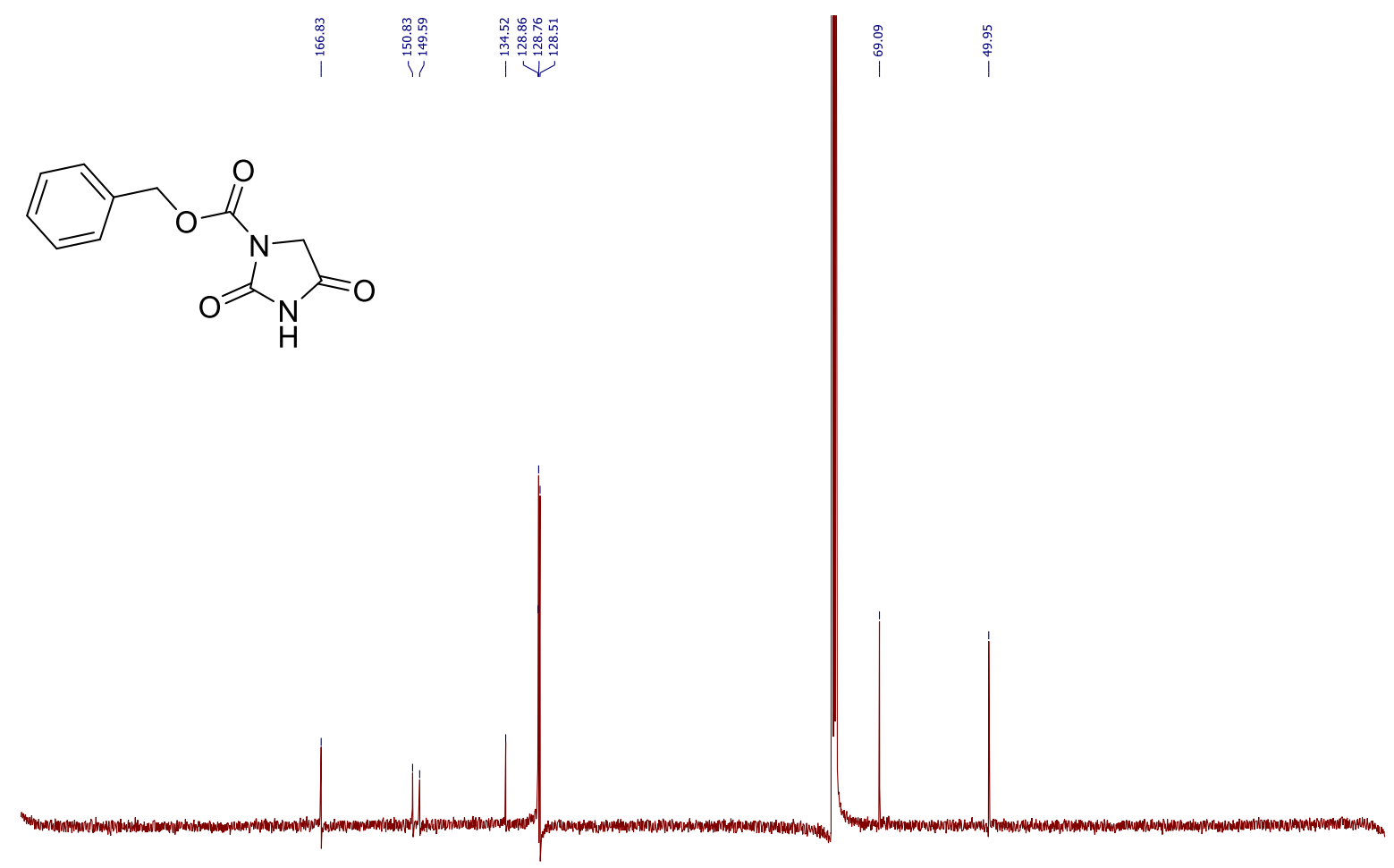

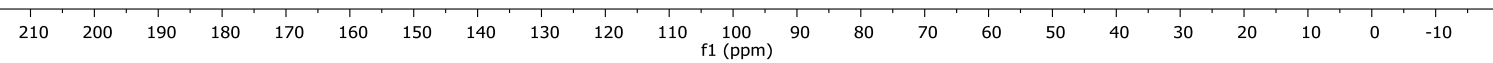


IR of compound $\mathbf{8 v}$

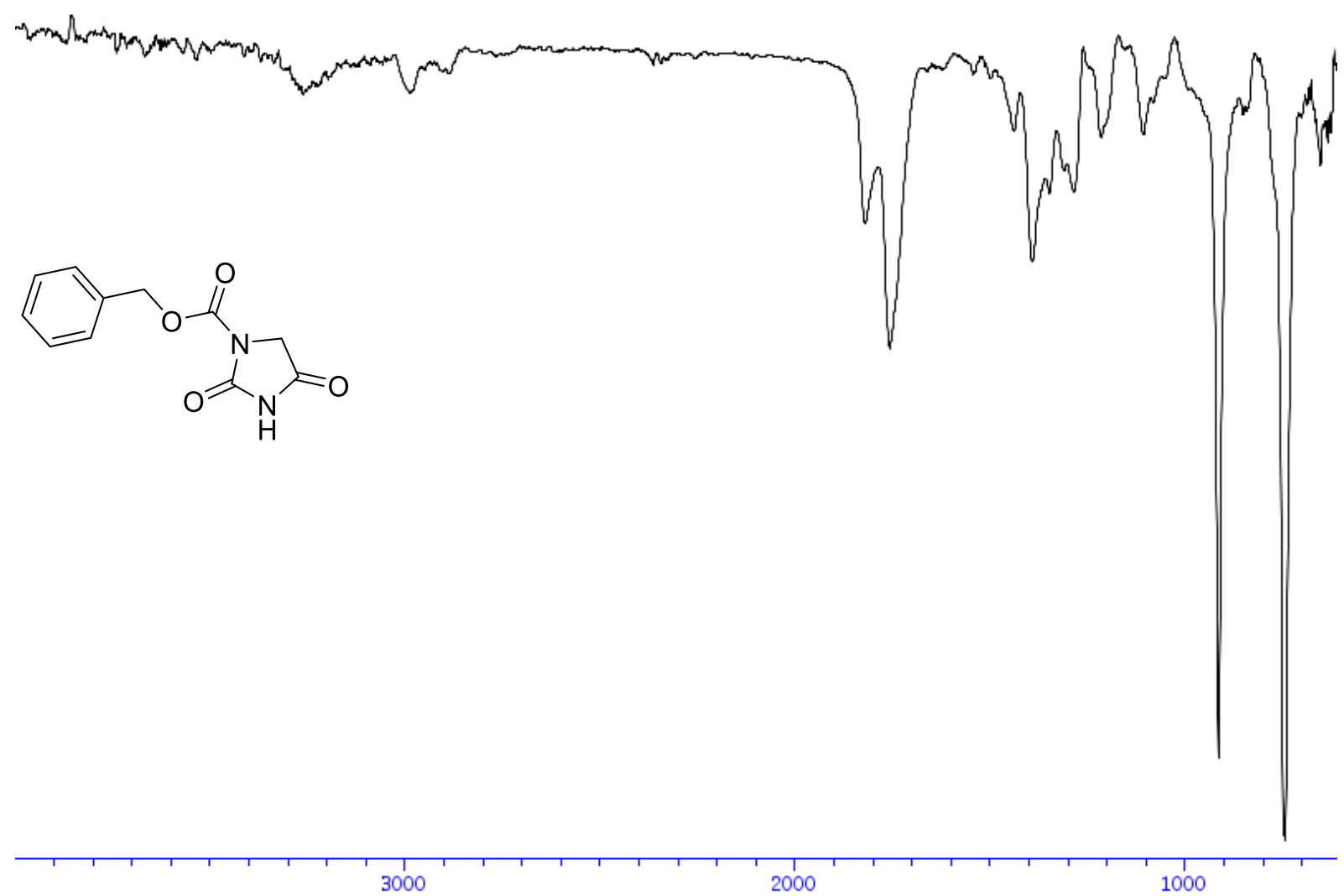


${ }^{1} \mathbf{H}-\mathbf{N M R}\left(400 \mathrm{MHz}, \mathrm{CDCl}_{3}\right)$ of compound $\mathbf{8 w}$

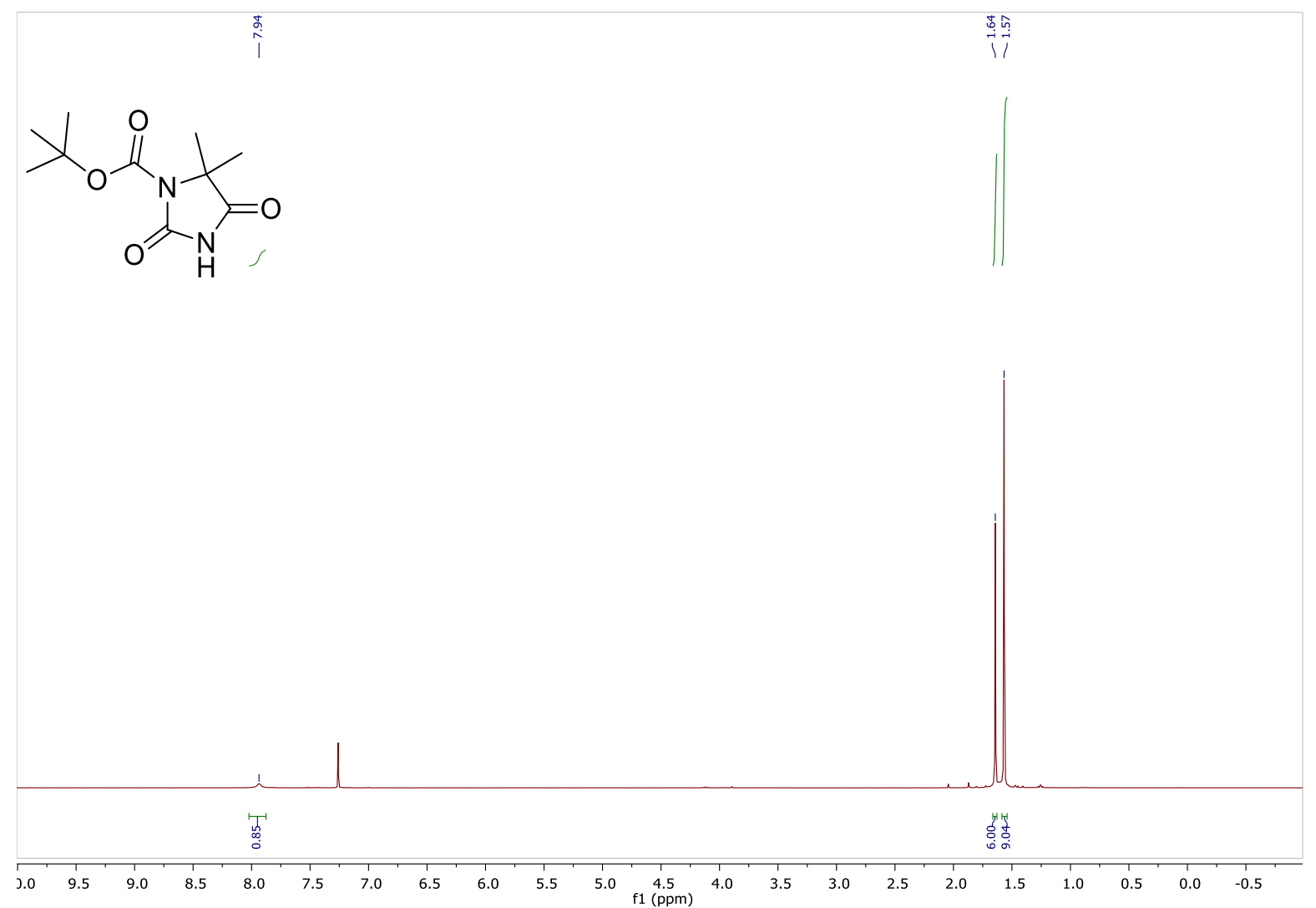

${ }^{13} \mathbf{C}-\mathrm{NMR}\left(100 \mathrm{MHz}, \mathrm{CDCl}_{3}\right)$ of compound $\mathbf{8 w}$

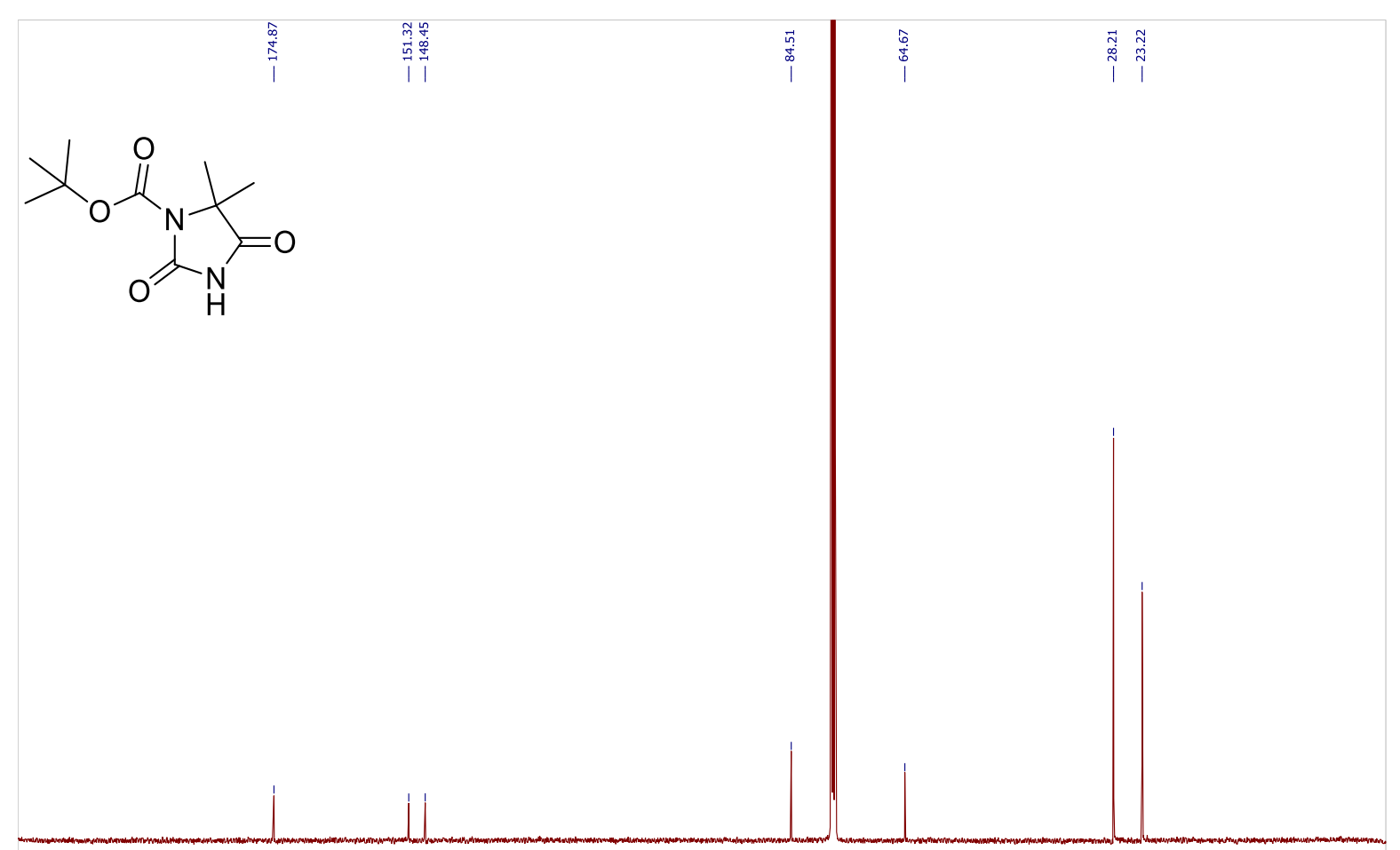

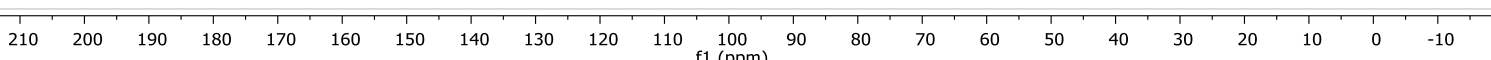


IR of compound $\mathbf{8 w}$

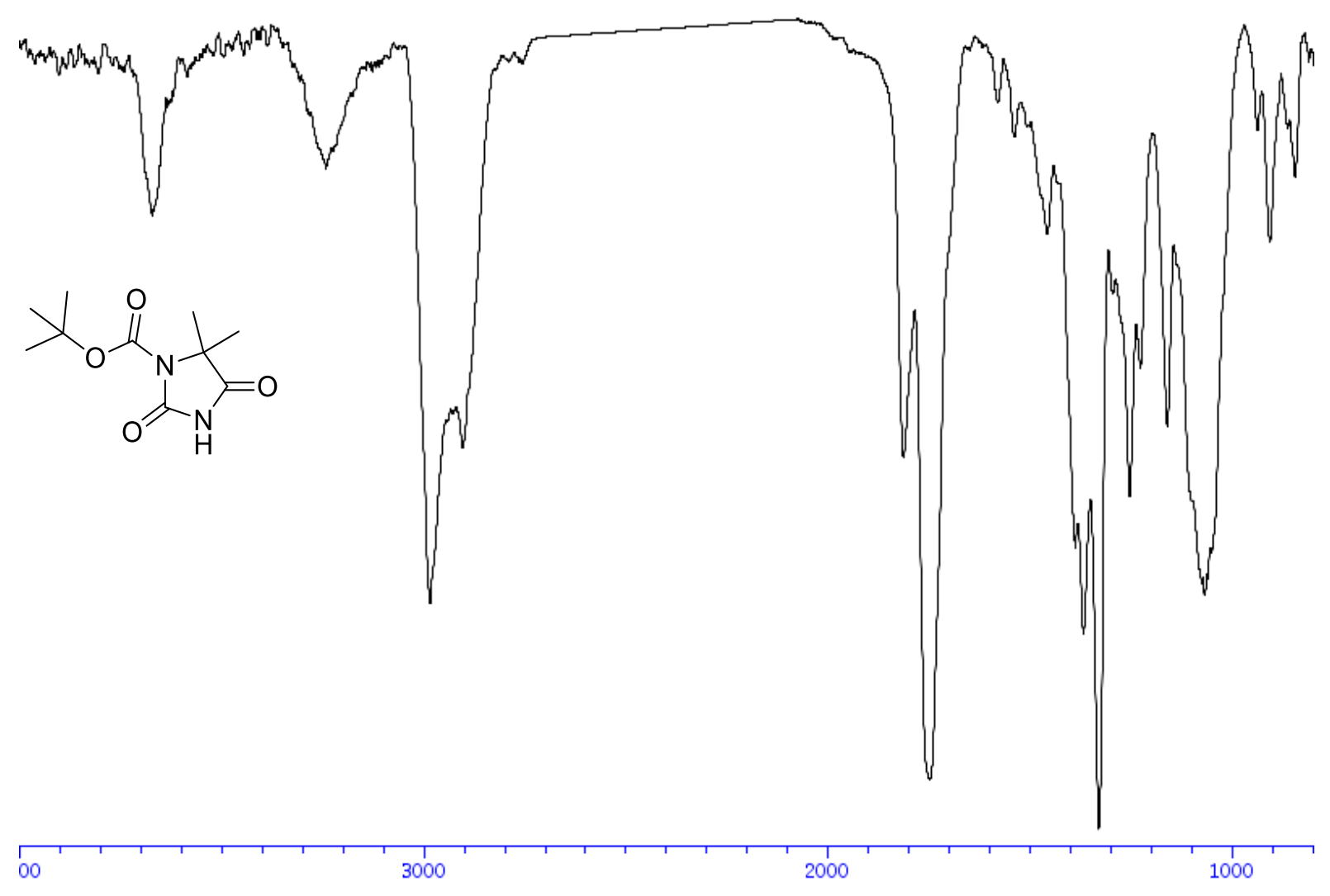


${ }^{1} \mathbf{H}-\mathrm{NMR}$ (400 MHz, DMSO-d6) of compound $\mathbf{1 0}$

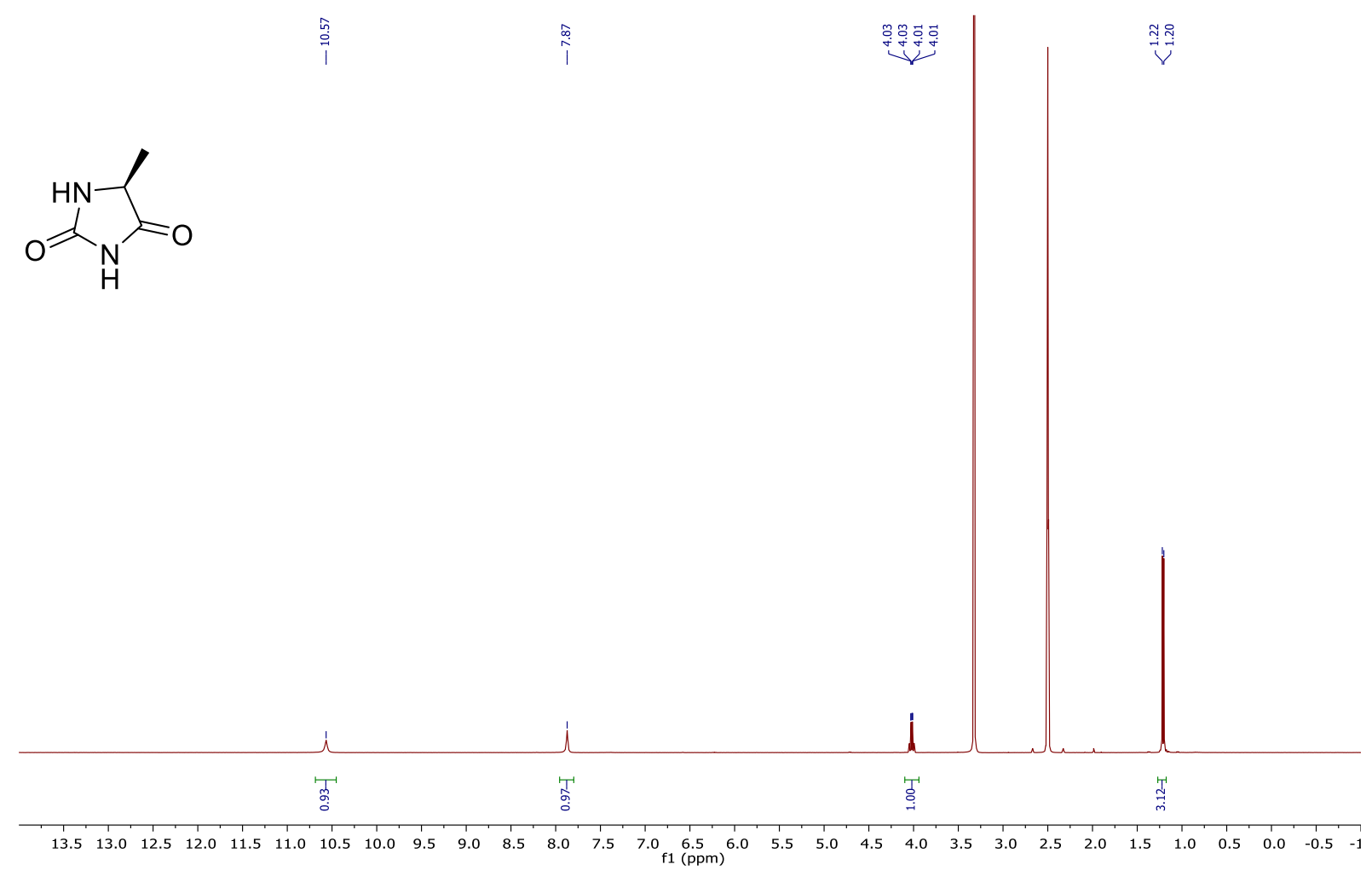

${ }^{13}$ C-NMR (100 MHz, DMSO-d6) of compound 10

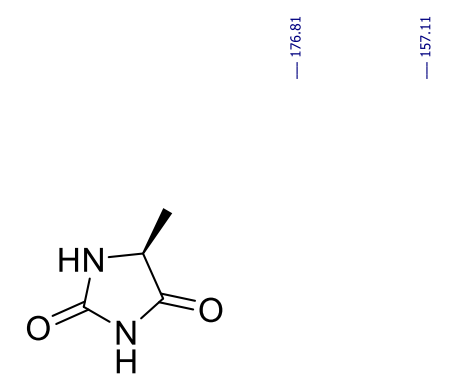

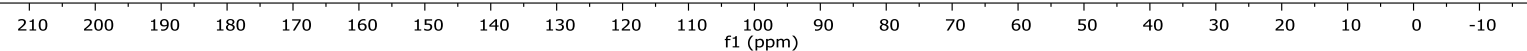


${ }^{\mathbf{1}} \mathbf{H}$-NMR $\left(400 \mathrm{MHz}, \mathrm{CDCl}_{3}\right)$ of compound 12a

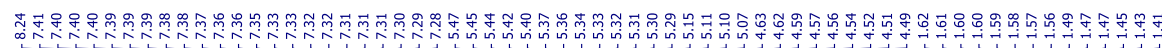<smiles>CC(NC(=O)OCc1ccccc1)C(=O)N1C(=O)NC(=O)C1C</smiles>

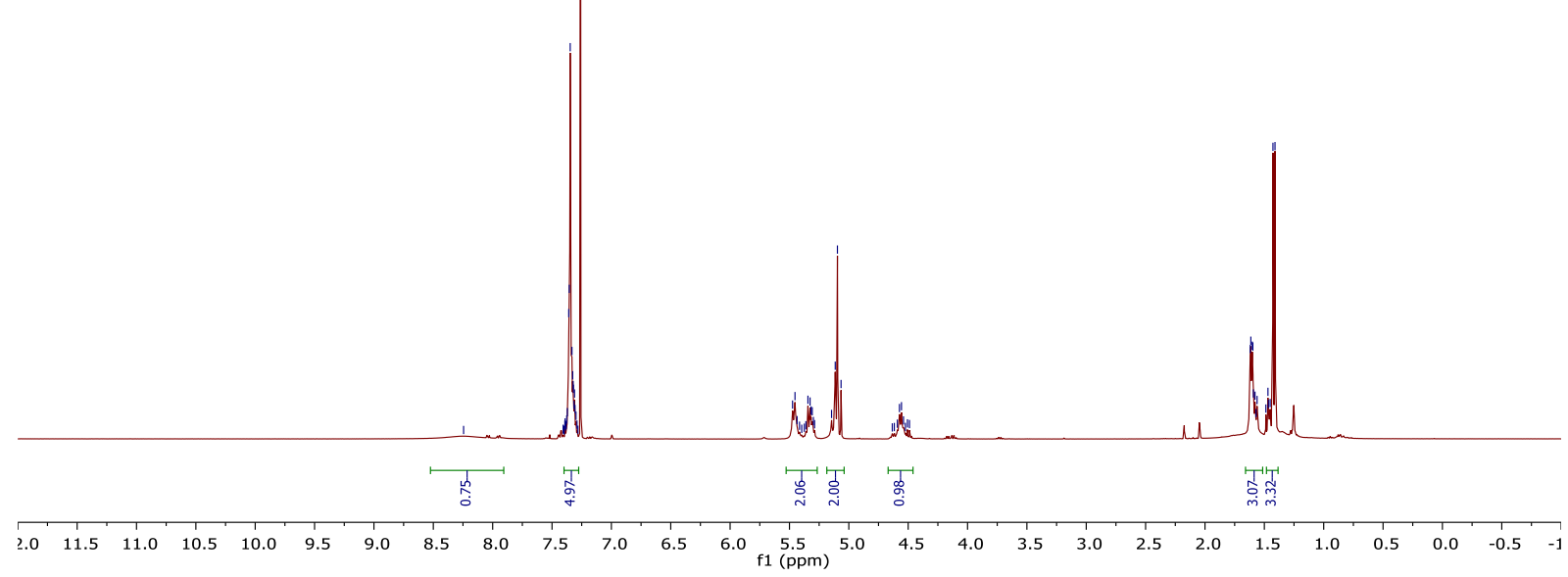

${ }^{13} \mathbf{C}-\mathrm{NMR}\left(100 \mathrm{MHz}, \mathrm{CDCl}_{3}\right)$ of compound 12a

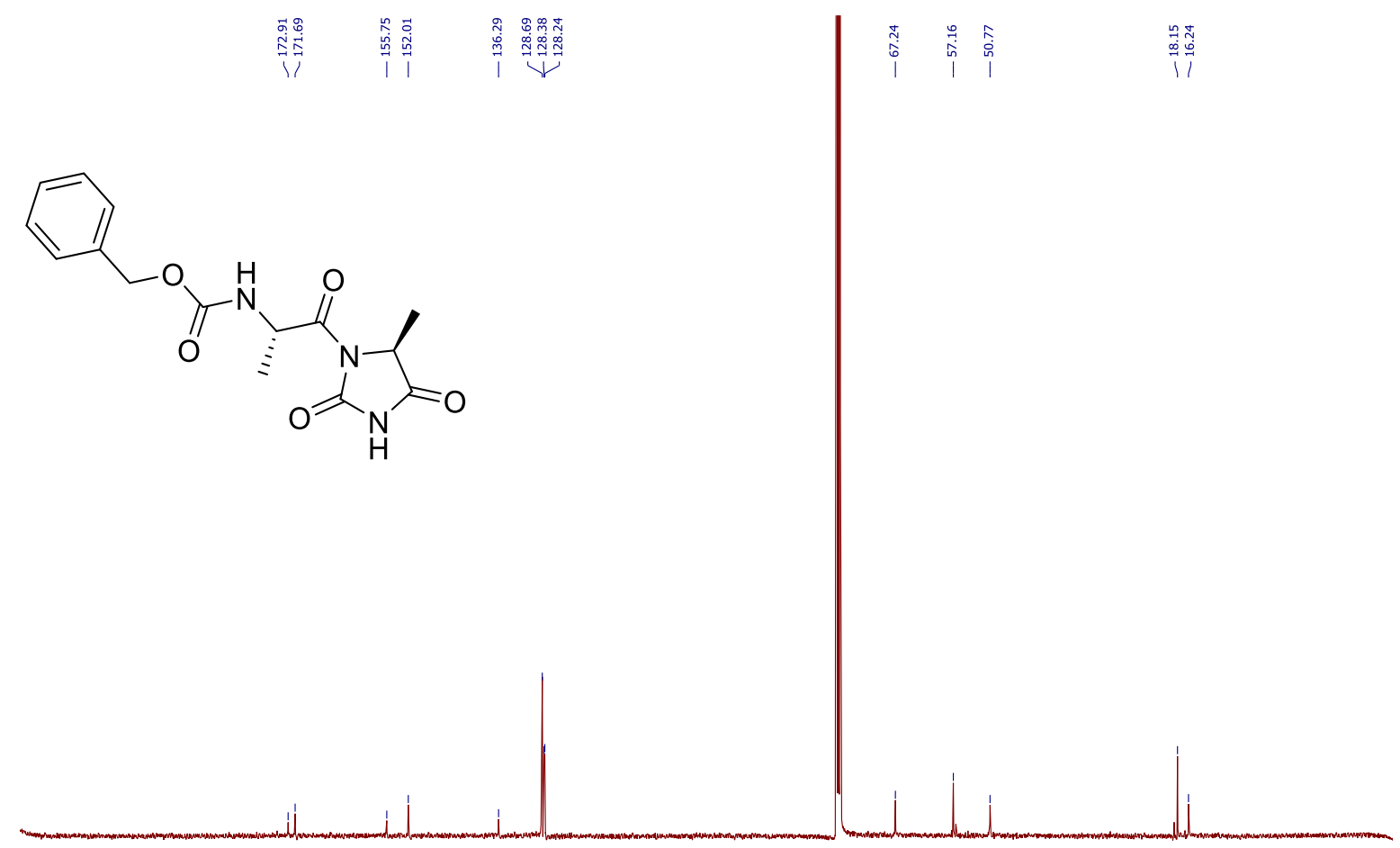

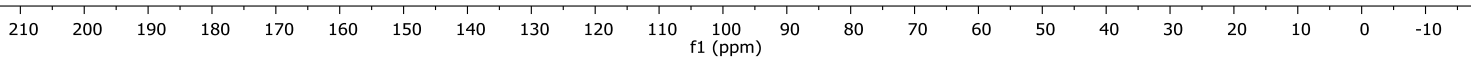


IR of compound 12a

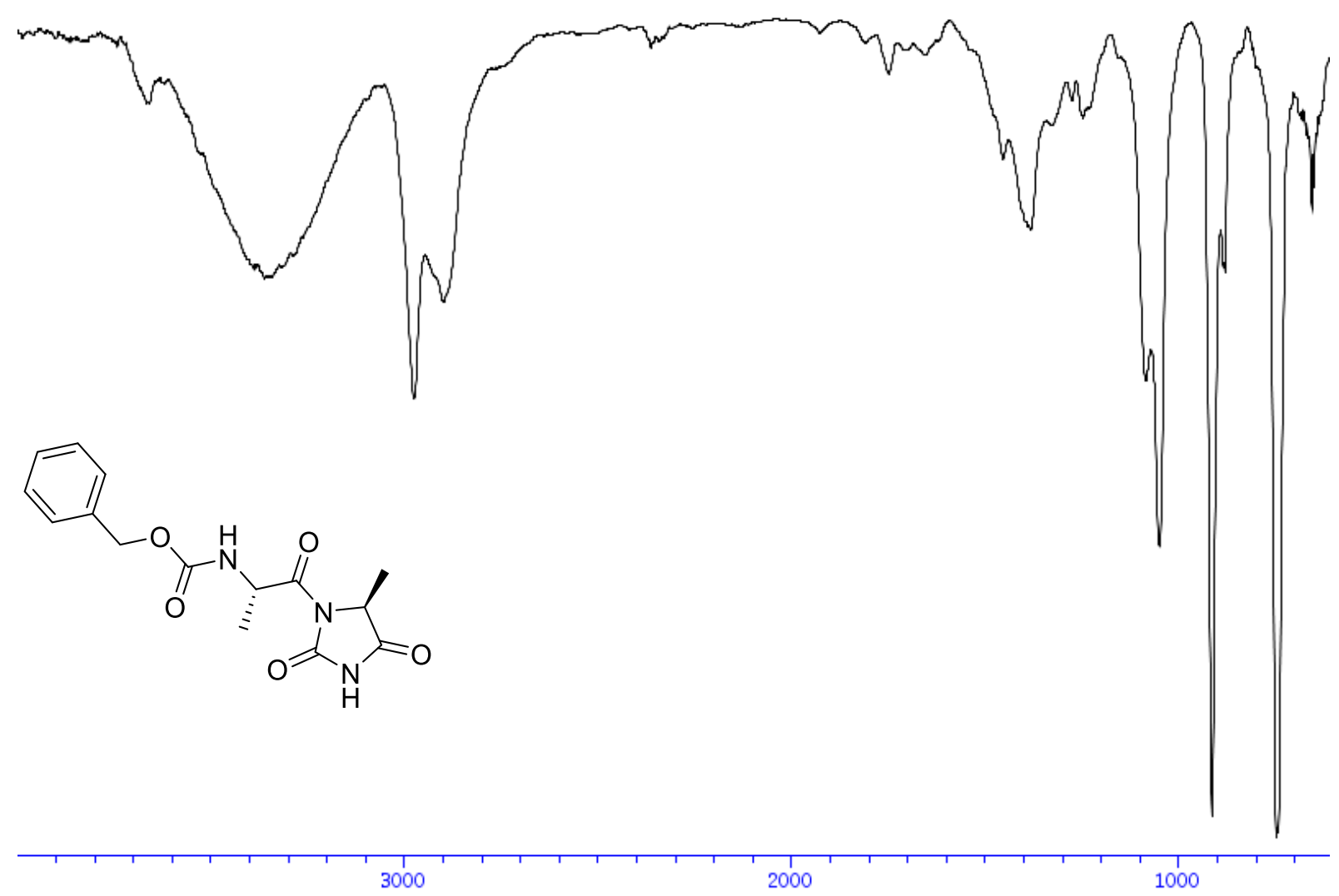

HPLC of compound 12a

Chiralpak ID 80:20 Hexane/iPrOH, $1.0 \mathrm{~mL} / \mathrm{min}, 60 \mathrm{~min}$.

Signal 2: DAD1 B, Sig=210,16 Ref $=360,100$

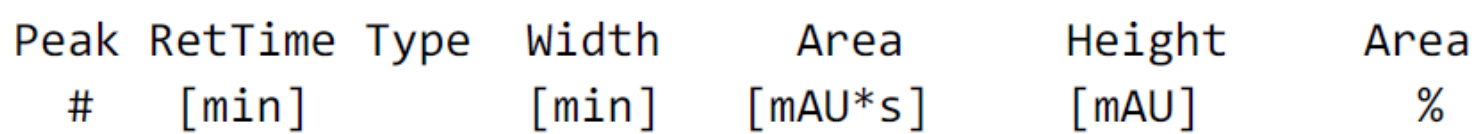

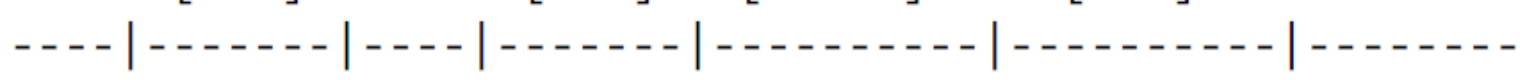
$\begin{array}{lllllll}1 & 24.876 & \text { MF } & 1.3271 & 1266.51709 & 15.90585 & 13.9515\end{array}$ $\begin{array}{llllll}2 & 27.116 \text { FM } & 1.9772 & 7811.45410 & 65.84715 & 86.0485\end{array}$ Totals : $9077.97119 \quad 81.75299$ 


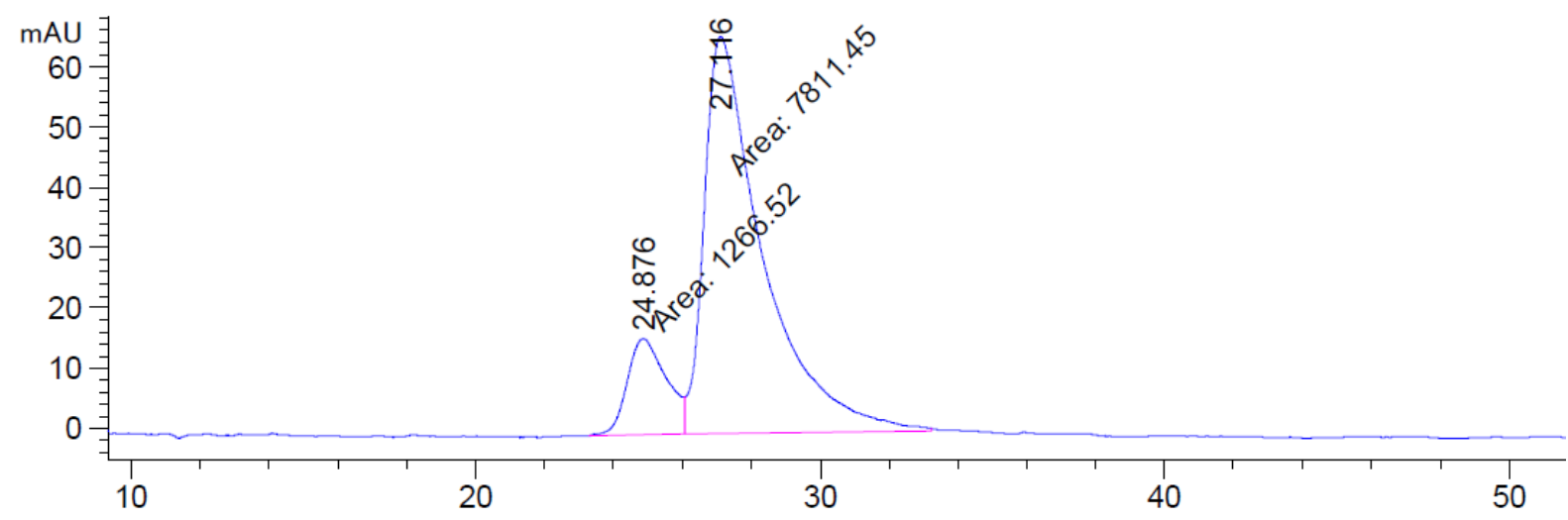

HPLC of diastereoisomers of compound 12a

Chiralpak ID 80:20 Hexane/iPrOH, $1.0 \mathrm{~mL} / \mathrm{min}, 60 \mathrm{~min}$.

Signal 2: DAD1 B, Sig=210,16 Ref $=360,100$

$$
\begin{aligned}
& \text { Peak RetTime Type Width Area Height Area } \\
& \text { \# [min] [min] [mAU*s] [mAU] \% }
\end{aligned}
$$

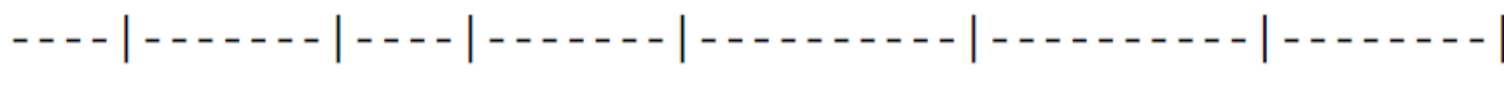

$$
\begin{aligned}
& \begin{array}{lllllll}
1 & 24.963 & \text { BV } & 1.2255 & 1.44973 \mathrm{e} 4 & 173.73763 & 33.3365
\end{array} \\
& \begin{array}{llllll}
2 & 27.333 \text { VB } & 1.9882 & 2.89905 \mathrm{e} 4 & 197.30777 & 66.6635
\end{array}
\end{aligned}
$$

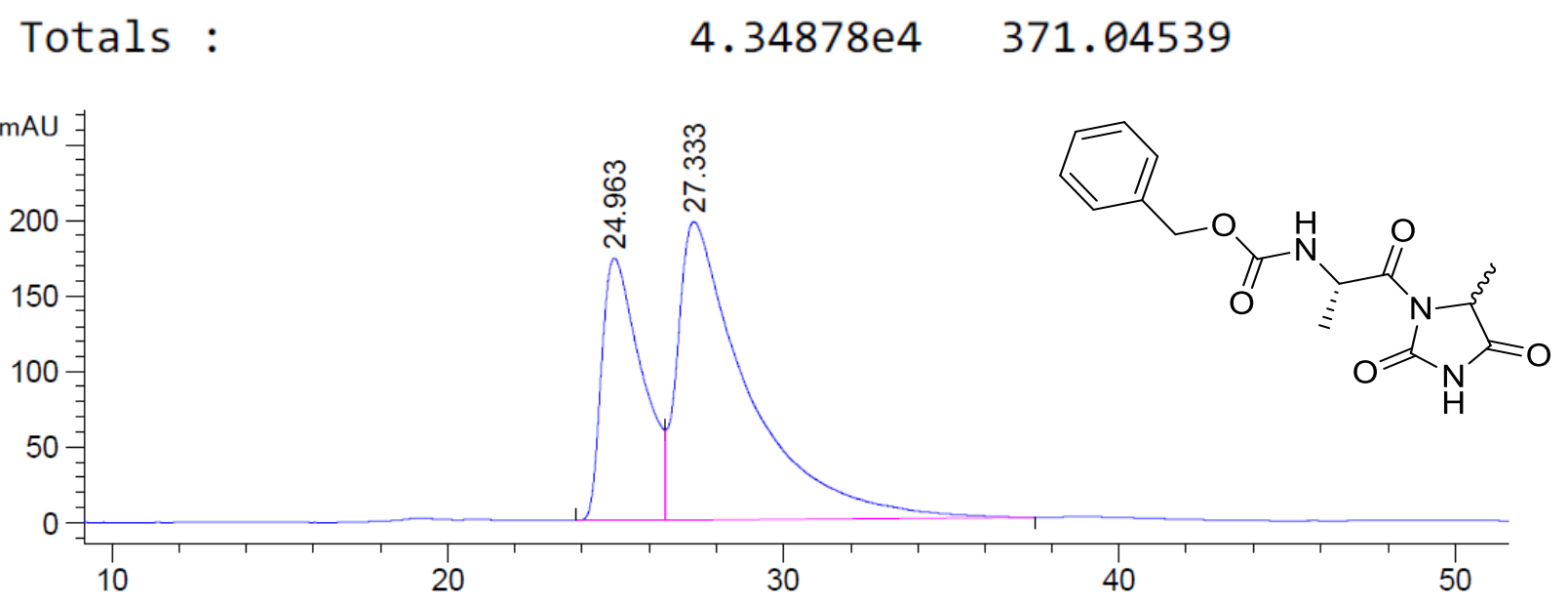


Signal 2: DAD1 B, Sig=210,16 Ref $=360,100$

Peak RetTime Type width Area Height Area \# $[\mathrm{min}] \quad[\mathrm{min}] \quad[\mathrm{mAU} * \mathrm{~s}] \quad[\mathrm{mAU}] \quad \%$

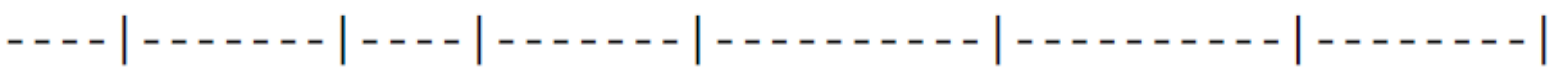

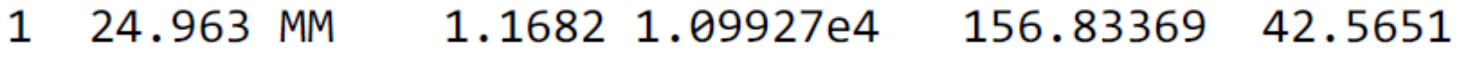

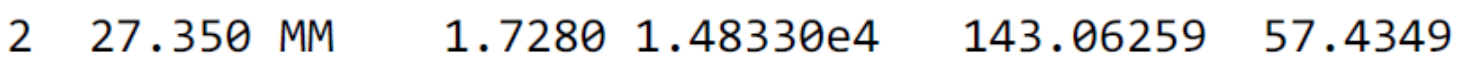

Totals :

$2.58257 \mathrm{e} 4 \quad 299.89629$

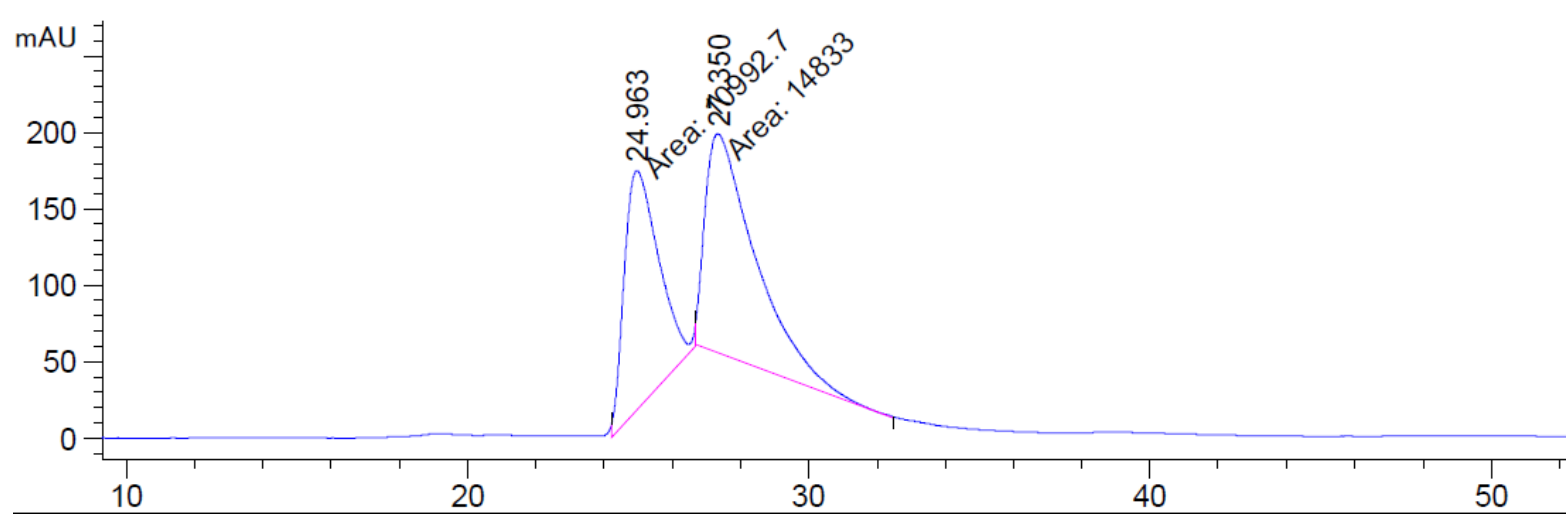


${ }^{\mathbf{1}} \mathbf{H}$-NMR (400 MHz, $\mathrm{CDCl}_{3}$ ) of compound 12b

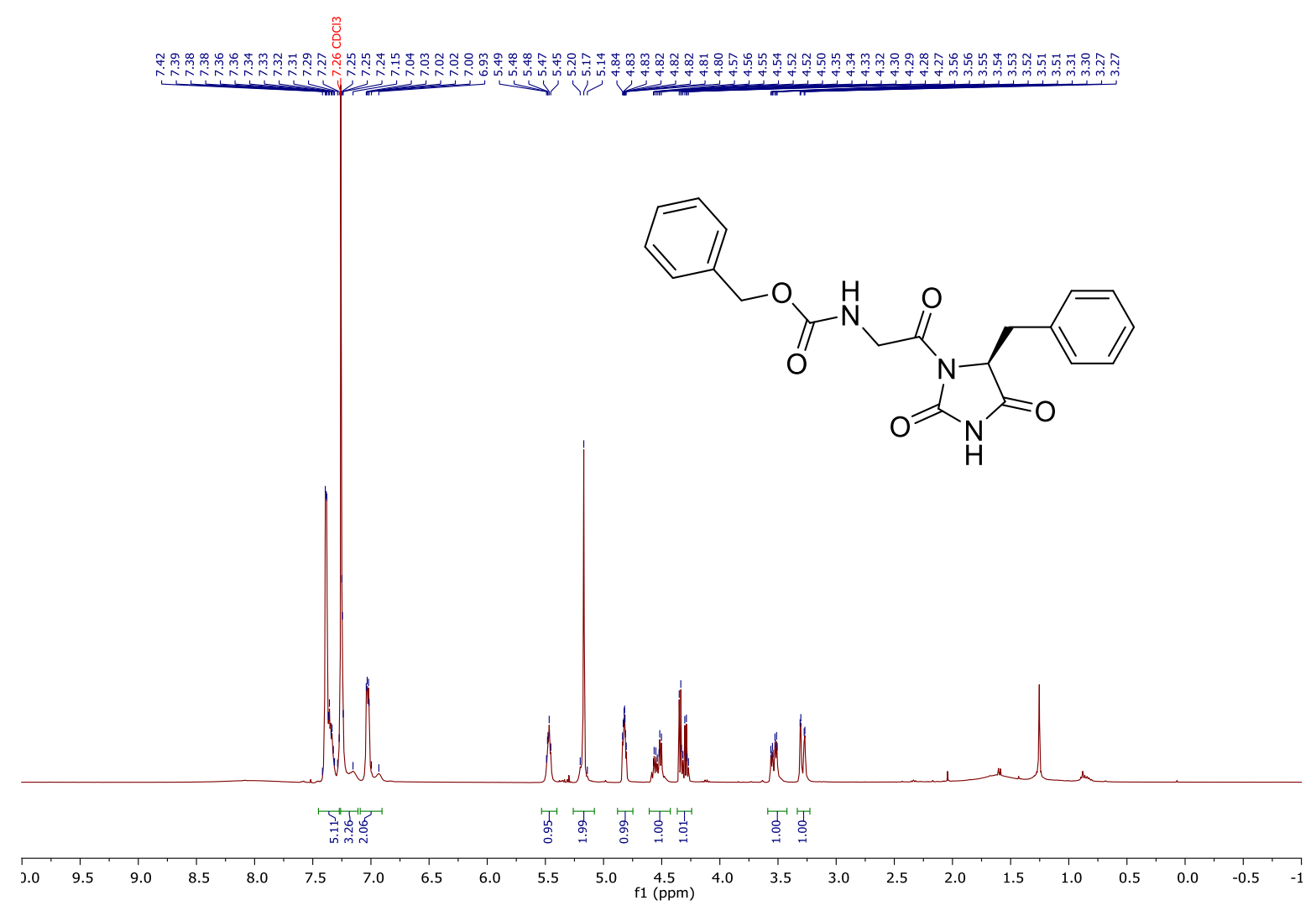

${ }^{13} \mathbf{C}-N M R\left(100 \mathrm{MHz}, \mathrm{CDCl}_{3}\right)$ of compound $\mathbf{1 2 b}$

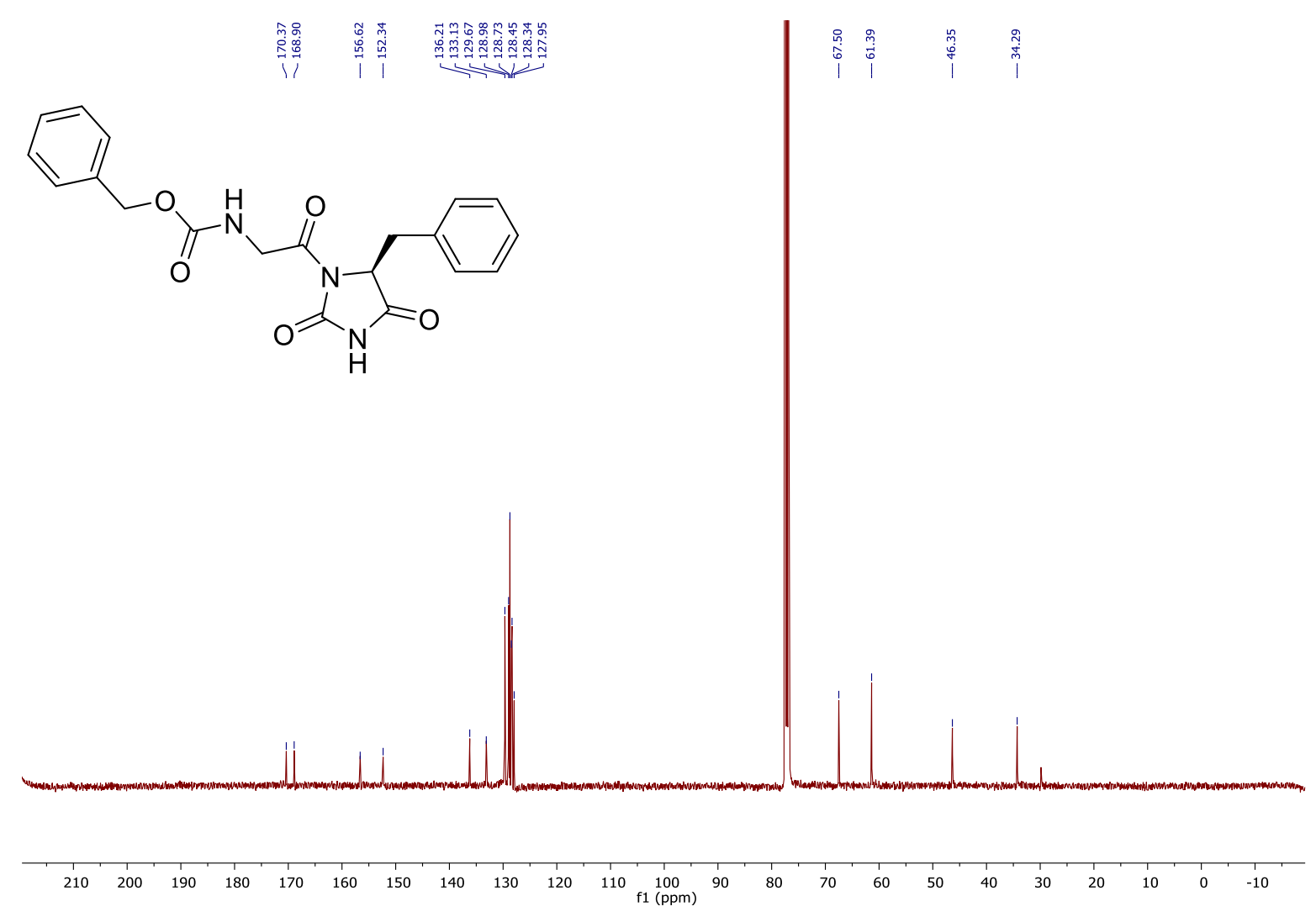


IR of compound $\mathbf{1 2 b}$

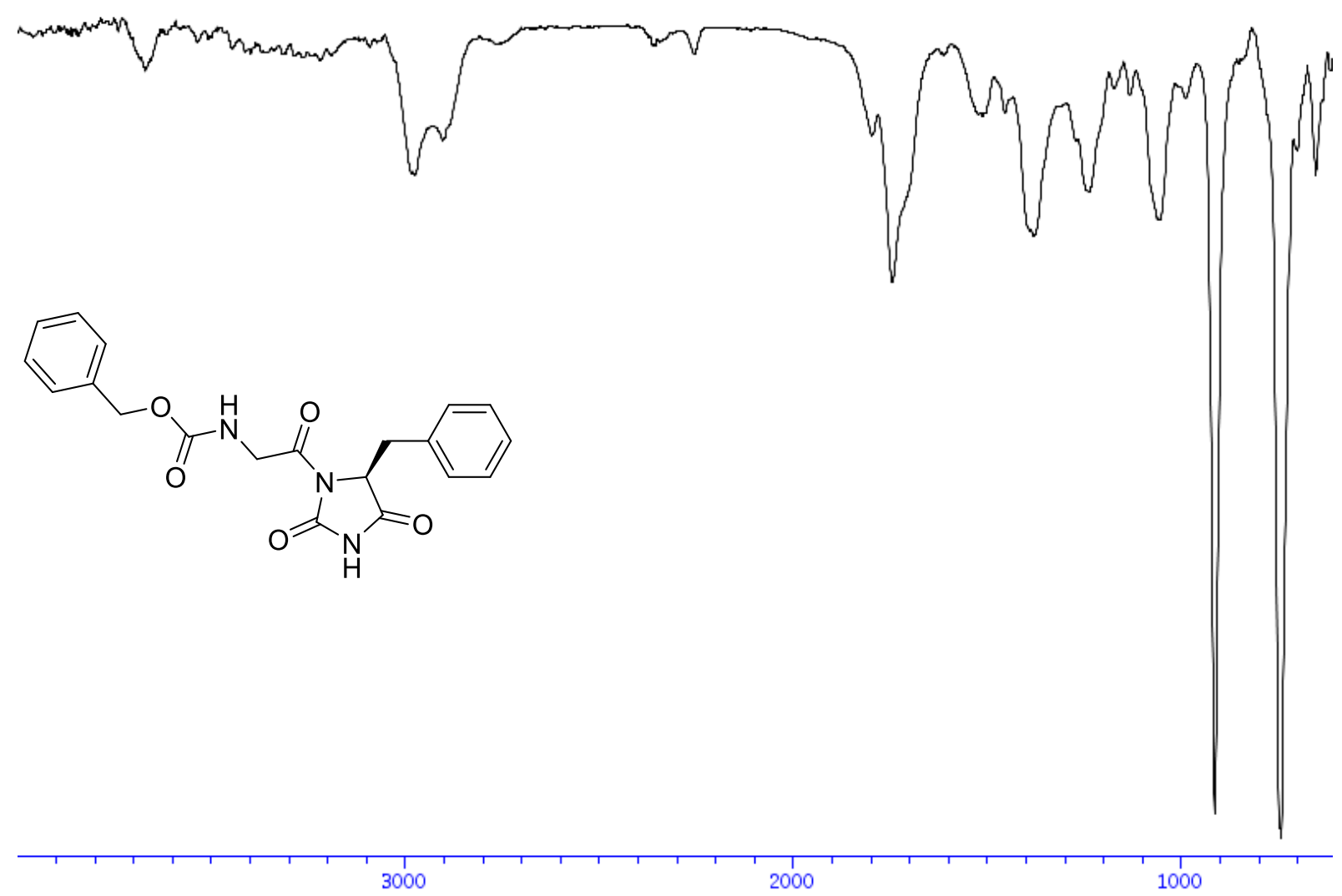

HPLC of compound 12b

Chiralpak ID 80:20 Hexane/iPrOH, $1.0 \mathrm{~mL} / \mathrm{min}, 60 \mathrm{~min}$.

Signal 2: DAD1 B, Sig=210,16 Ref $=360,100$

\begin{tabular}{|c|c|c|c|c|c|c|}
\hline $\begin{array}{c}\text { Peak } \\
\#\end{array}$ & $\begin{array}{c}\text { RetTime } \\
\text { [min] }\end{array}$ & Type & $\begin{array}{l}\text { Width } \\
\text { [min] }\end{array}$ & $\begin{array}{c}\text { Area } \\
{\left[\mathrm{mAU}^{*} \mathrm{~s}\right]}\end{array}$ & $\begin{array}{l}\text { Height } \\
{[\mathrm{mAU}]}\end{array}$ & $\begin{array}{c}\text { Area } \\
\%\end{array}$ \\
\hline & & & & |-- - - - - & & $\mid$ \\
\hline 1 & 29.345 & BB & 1.6992 & 4627.91846 & 36.11084 & 28.0741 \\
\hline 2 & 40.697 & BB & 3.0536 & $1.18567 \mathrm{e} 4$ & 45.68857 & 71.9259 \\
\hline
\end{tabular}

Totals :

$1.64846 \mathrm{e} 4 \quad 81.79942$ 


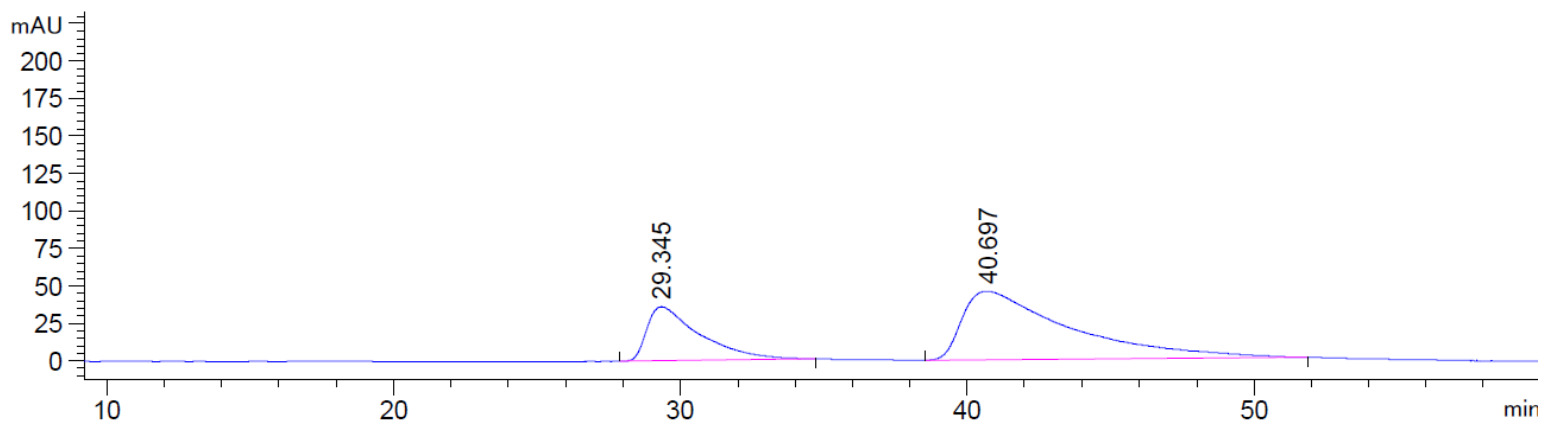

HPLC of racemate of compound 12b

Chiralpak ID 80:20 Hexane/iPrOH, $1.0 \mathrm{~mL} / \mathrm{min}, 60 \mathrm{~min}$.

Signal 2: DAD1 B, Sig=210,16 Ref $=360,100$

Peak RetTime Type Width Area Height Area

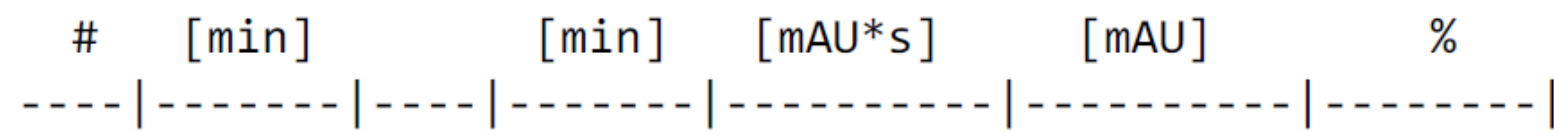

$\begin{array}{lllllll}1 & 26.833 & \text { BB } & 1.3789 & 4.23652 \mathrm{e} 4 & 422.83505 & 50.6460\end{array}$

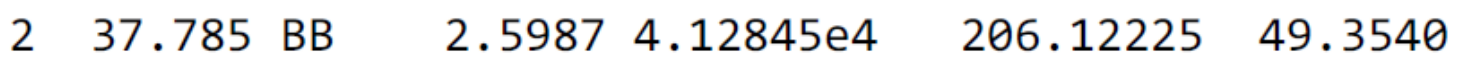

Totals : $\quad 8.36497 e 4 \quad 628.95731$

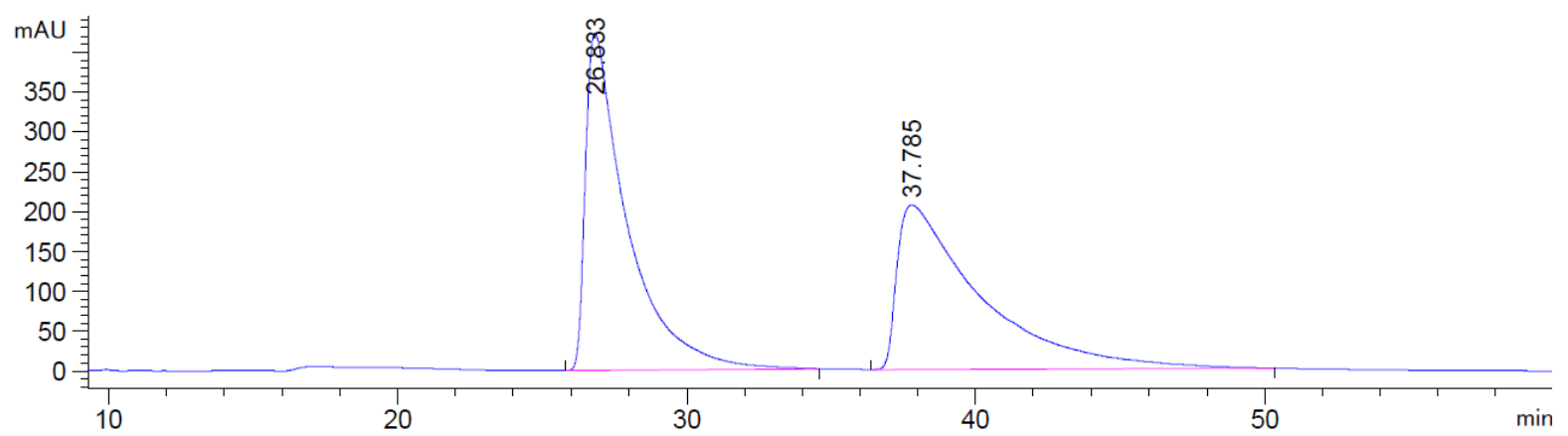

